\title{
ON THE BIOLOGY OF THE SMALL COPEPODS IN LOCH STRIVEN
}

\author{
By S. M. Marshall, D.Sc.
}

From the Marine Station, Millport

(Text-figs. I-32)

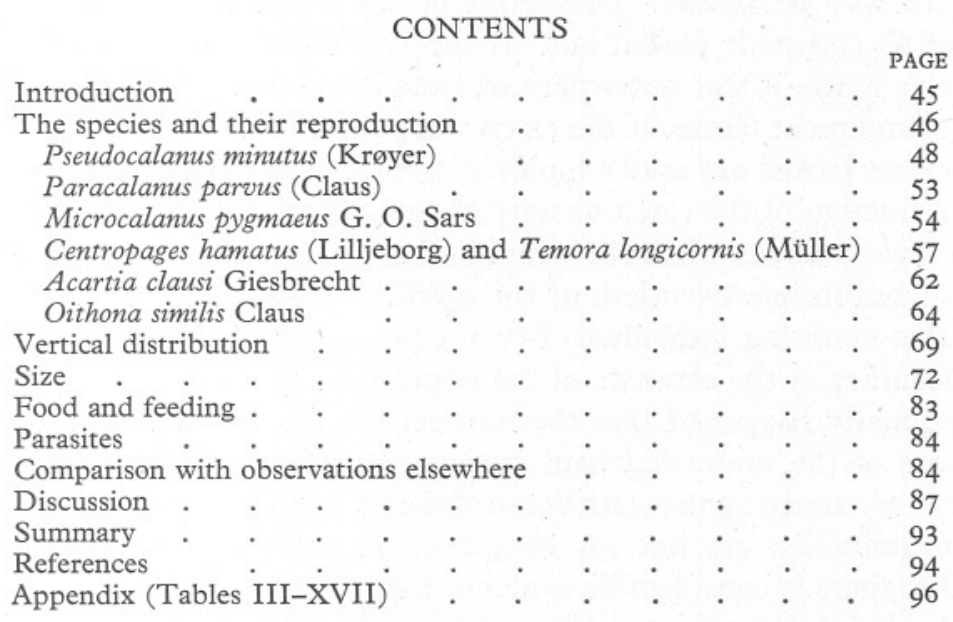

INTRODUCTION

The importance of copepods in the economy of the sea is generally recognized, but our knowledge of their seasonal variations in breeding and growth is as yet very incomplete. The object of the present investigation is to study throughout a year the variations in the small copepods of Loch Striven in the Clyde sea area. Fortunately, the tow-nettings which had already been studied for Calanus finmarchicus (Marshall, Nicholls \& Orr, 1934) were available and offered an opportunity of comparing the seasonal changes in the small copepods with those in Calanus and in the phytoplankton. The hauls were therefore re-examined and the small copepods picked out and separated into their developmental stages.

Details of the method of taking the hauls are given in the paper mentioned above. It is sufficient to say here that on each occasion five vertical hauls were taken with a modified Standard International Net of fine silk (200 meshes to the inch), and that from 27 March to 2I August inclusive one of the five was taken in two parts, the first from the bottom $(60-70 \mathrm{~m}$.) to Io m., and the second from Io $\mathrm{m}$. to the surface. The five hauls were examined by eye, and if the four undivided hauls appeared to be similar they were mixed together; if one appeared decidedly different from the rest, it was kept separate and either 
not counted, or its figures not included in the final estimate. The divided haul was of course always counted separately.

Figures and tables giving data for temperature and numbers of phytoplankton organisms on the dates when the hauls were taken are given in the paper cited above.

Methods of preservation, sampling and measurement were the same as described by Nicholls (1933) and Marshall (1933). In all but the first five stations where, for Oithona, only one-fifth of the catch was counted, the procedure was as follows. One-tenth of the catch was examined, and all stages of all copepods picked out. If the total number of any stage reached Ioo in this tenth, it was not separated from the remaining nine-tenths of the catch. Subsequent tenths of the catch were examined and the other stages of the copepods picked out until a hundred of each stage had been separated from a known fraction of the catch or until the whole catch had been examined.

On a few occasions when the nauplii of a species were very numerous they were counted in one-twentieth of the catch. Winsor \& Walford (I936) have shown that counting individuals beyond the number of Ioo adds very little to the accuracy of the estimate of the population.

It frequently happened that the numbers in the divided haul were lower than those of the undivided haul average, and I am much indebted to Dr $\mathrm{H}$. Barnes for studying the statistics of these variations in number. The results of his examination are not yet complete. However, it may be tentatively stated that there is considerable evidence that a proportion of the catch is lost in the divided hauls; this loss affects the numbers below Io $\mathrm{m}$. only. The loss was not constant throughout the season, but on occasion it was of the order of $50 \%$ of the total catch below Io $\mathrm{m}$.

The figures for the vertical distribution determination have necessarily to be obtained from the counts of these divided hauls, and the actual proportions above and below the Io $\mathrm{m}$. level may therefore be subject to a variable error; qualitatively the seasonal changes are accurately represented.

When, according to the counts of Calanus already made by Dr A. G. Nicholls (1933), the divided and undivided hauls did not differ much, only the former was counted. This was so on ten dates between 27 March and 2I August; on twelve the undivided were also sampled and counted. In plotting the total numbers and percentage distribution of the stages (Figs. I-I4) throughout the season the estimates from the undivided hauls were used when available; those from the divided haul only are marked with an asterisk.

\section{The Species and their Reproduction}

Nine species occurred in Loch Striven, six of them in abundance. Pseudocalanus and Microcalanus occurred throughout the year. Following With (I9I5) Pseudocalanus minutus (Krøyer) is taken to include P. elongatus, and Microcalanus pygmaeus G. O. Sars to include M. pusillus G. O. Sars. 
Paracalanus parvus (Claus) occurred also, but, apart from nauplii of which a few were probably always present, not in numbers until July. Two species of Centropages occur. C. hamatus (Lilljeborg) was the common species; C. typicus Krøyer appears occasionally in the Clyde sea area, but it was not observed in the Loch Striven catches. Temora longicornis (Müller) and Acartia clausi Giesbrecht were the common representatives of their genera. A. discaudata (Giesbrecht) has been observed in the Clyde sea area, but not in Loch Striven.

Oithona similis Claus was the most abundant copepod and occurred the whole year round. This species is the one named by Sars (I9I8, p. 207) $O$. similis (emended from his description of it as O. helgolandica Claus (ibid., p. 8)). There are slight discrepancies in the literature about the armature of the exopods of the swimming feet by which the species are distinguished, so the Loch Striven form was examined.

The exopods are three-segmented, and one of the distinguishing characters is the number of external spines and internal setae on the terminal segments of these exopods. In the key given by Wilson (1932, p. 3II) the number of external spines on the terminal segments of the first four swimming feet in the female $O$. similis is said to be 2, I, I, I, but in his description of $O$. similis on p. 3 I4 it is given as 2, I, I, O. Rosendorn (I927), in her study of the genus from the material of the Valdivia expedition, agrees with Wilson's key. Sars, in his description (I9I8, p. 8), mentions a spine on the terminal exopod segment of the fourth foot but does not show one in his figure (Pl. III, p. 4). In the Loch Striven specimens the number of external spines on the terminal exopod segments of the first three swimming feet is $2, \mathrm{I}, \mathrm{I}$, and on the fourth there is, not a spine, but a fine seta which often lies close to the apical spine and is difficult to see.

Rosendorn gives the number of internal setae on this same terminal exopod segment as $5,5,5,5$, for the first four swimming feet, but Sars, in the figure already mentioned, shows only four on the first swimming foot and this agrees with the Loch Striven specimens.

Oithonina nana (Giesbrecht) also occurred; it was most common in February and March, decreased in April and almost disappeared during the summer. Its numbers began to rise again slightly in September and October. In the end of March and in April, when one haul was divided at ro m., it was almost invariably found in the bottom part of the haul and might there be almost as numerous as Oithona similis, which at that time was concentrated in the top ro $\mathrm{m}$. The nauplii were not distinguished and the numbers of these given for $O$. similis probably include a small number of Oithonina nauplii, but even in February and March they were not numerous enough to affect the general result.

The nauplii of Calanus, Pseudocalanus, Paracalanus and Microcalanus are difficult to distinguish except by size. When only Pseudocalanus and Micro- 
calanus were present their nauplii could be distinguished fairly easily, but when Paracalanus was present also it was much more difficult, and the numbers of nauplii are certainly less accurate than those for copepodites.

The five copepodite stages and the adults (male and female) were all separated, but the six nauplius stages of each species were lumped together. Copepods pass through the nauplius stages so quickly that since visits were made only once a week the proportions of the nauplius stages present could give no information about the development of broods.

The paper by Oberg (1906) was found very useful for identifying the nauplii and that by Kraefft (I9IO) for distinguishing the sexes of the copepodite stages.

\section{Pseudocalanus minutus (Krøyer) \\ (Table III and Figs. I and 2)}

The female does not normally develop a fifth leg, so the sexes can be distinguished easily in copepodite Stages IV and V. Occasional female specimens are found, both adult and Stages IV and V, which have a small fifth leg, but in such females the legs do not resemble those of the males, being smaller. Such specimens have already been described by With (1915). In the Loch Striven samples less than I \% showed this abnormality (4 Stage IV, I3 Stage $\mathrm{V}$, and 4 adult females).

The percentage distribution of the various stages is shown in Fig. I and the variation in total numbers in Fig. 2. It was not found possible to count the eggs in those species of copepod which do not carry an egg-sac, and, for the sake of uniformity, eggs are not shown in Fig. I. As can be seen in Fig. 2, nauplii usually outnumbered eggs considerably, which is to be expected from the greater length of time (judging from Calanus) spent in the nauplius stages. During a good part of June and July, however, eggs were slightly more numerous than nauplii.

In the Fig. I type of diagram a developing brood is clearly indicated when the peaks for successive stages move to the right from bottom to top. The peaks for several developmental stages may occur on the same date, since the maximum abundance of any one stage is naturally often missed, but when all the peaks, or a majority of them, occur on the same date it indicates merely a sudden drop in the proportion of nauplii which is usually the most abundant stage.

In most Figures the times when diatoms were rich (arbitrarily fixed as over I00 cells $/ \mathrm{ml}$.) are marked along the foot of the diagrams by thick black lines.

When observations began in the middle of January, $50 \%$ of the stock of Pseudocalanus consisted of Stage V copepodites, and almost all the rest was made up of eggs, nauplii and adults (Table III, Figs. I, 2). During the next 4 weeks the Stage V moulted into adults, the females then spawned, and on 
20 February over $80 \%$ of the stock was present as eggs and nauplii (Fig. I). These eggs and nauplii began to develop and the early copepodite stages became more numerous during February and March. From Fig. I it looks as

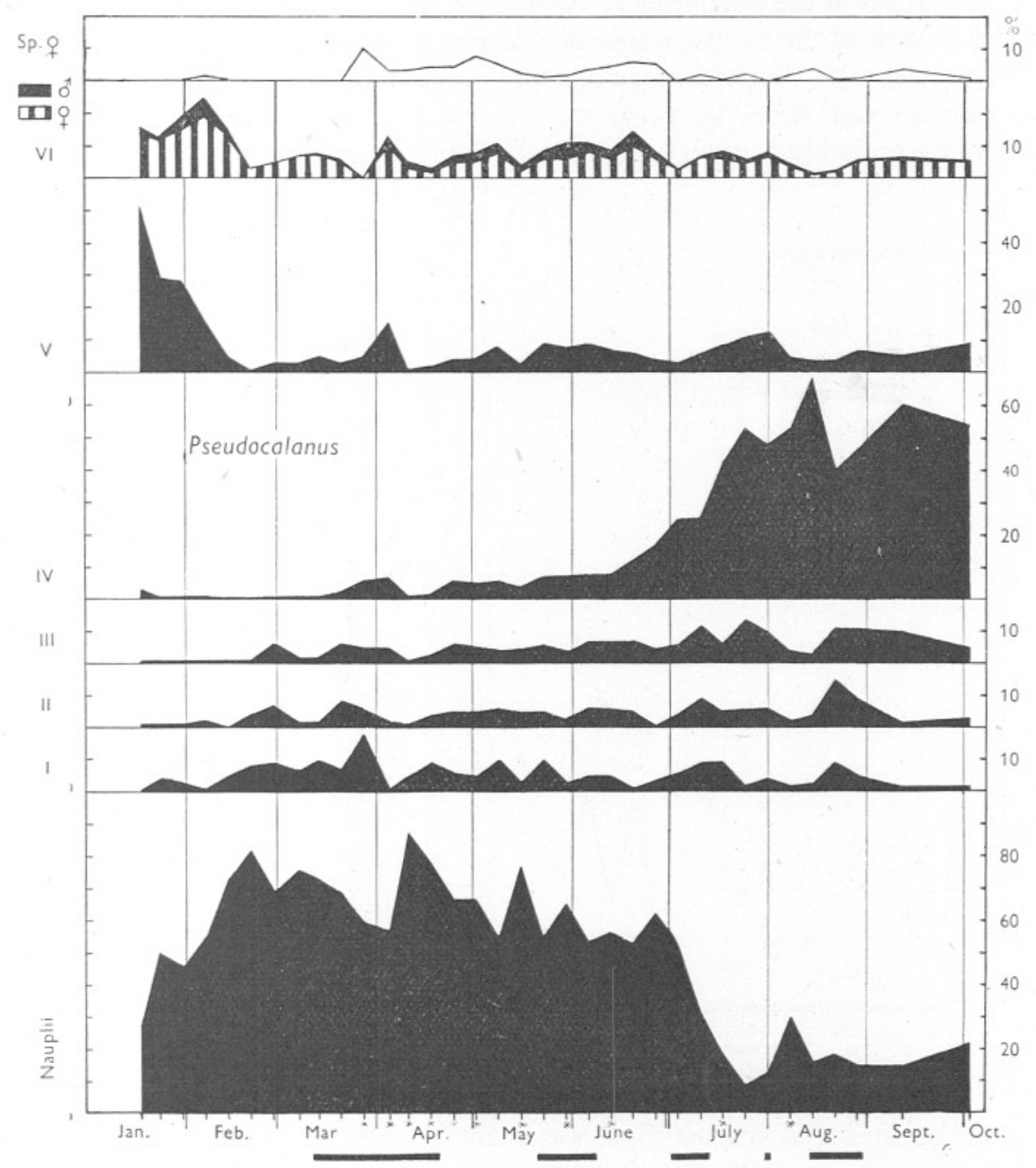

Fig. I. Pseudocalanus minutus. Diagram showing the percentage of the developmental stages during the year. The percentage of adult females with spermatophores $(S p$. ㅇ) is shown at the top. An asterisk indicates that counts were from a divided haul only (see p. 46). Periods of main diatom outbursts are marked by thick lines at the bottom of the Figure.

if the earlier nauplii of this brood did not complete their development, whereas the later nauplii did (Stage III appeared in numbers first on 27 February, Stage IV not till 4 April), becoming Stage V and adult about the beginning of April. It may be noted that the spring diatom increase began on I3 March 
and would supply food for the later-produced nauplii and copepodites but not for the earlier. The actual numbers of the whole of this first brood were small, only a few hundred, and therefore it does not show on Fig. 2.

The adults of the beginning of April gave rise to another increase of nauplii in the middle of the month, whose development can be traced in the succeeding weeks. After this the percentage of nauplii remains high though variable, there are no distinct series of peaks on the curves for copepodite stages and breeding probably goes on continuously until July, when it falls off markedly.

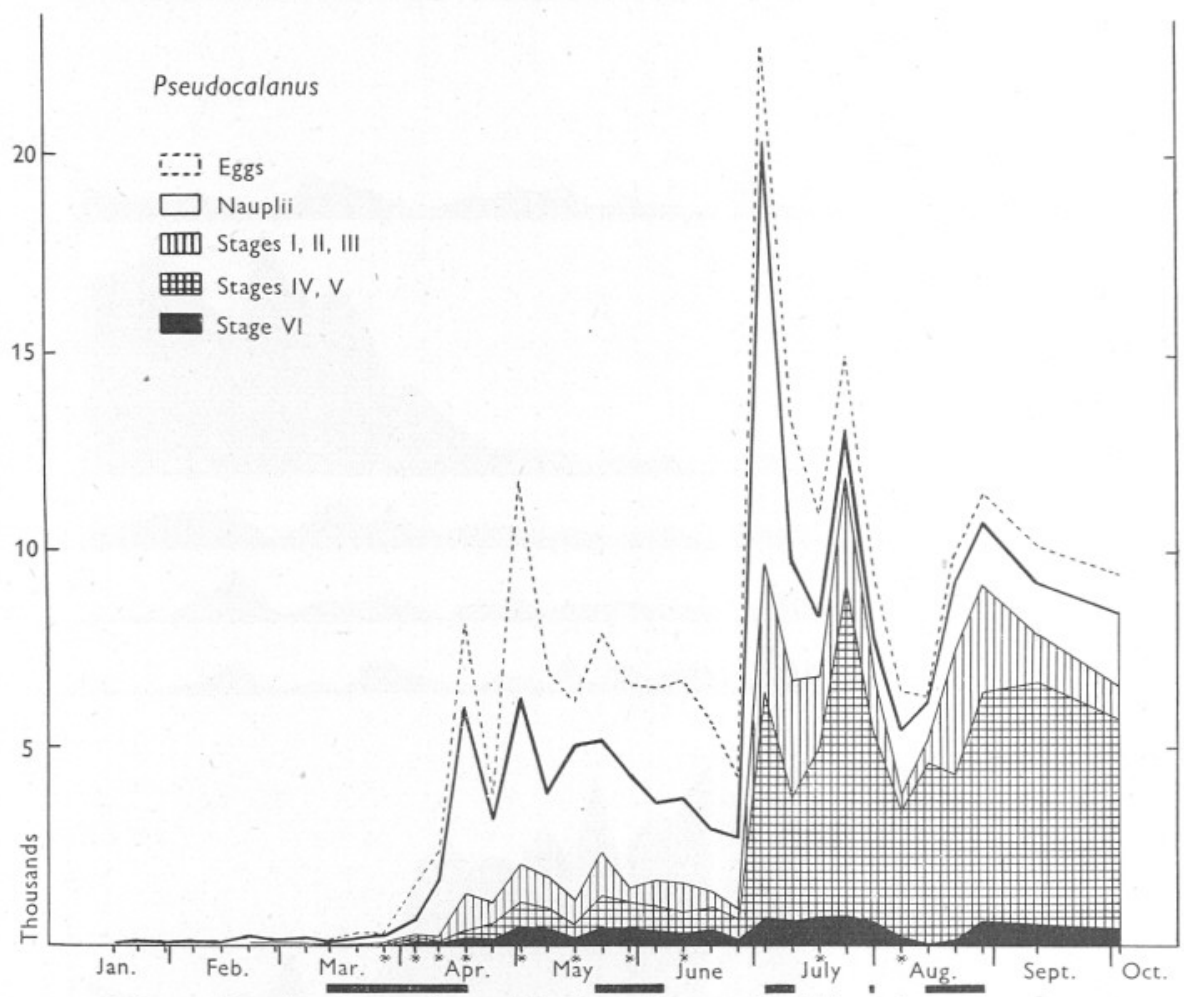

Fig. 2. Pseudocalanus minutus. Total number per haul throughout the year.

At the beginning of August there was a small but well-defined rise in the percentage of nauplii, followed a fortnight later by a rise in the percentage of early copepodites. This autumnal brood, however, does not get beyond Stage IV. Even from the beginning of July there was a very marked fall in the proportion of nauplii, and at the same time the number of Stage IV copepodites began to increase and continued to do so throughout the month and till the middle of August. From then till observations stopped at the beginning of October the proportion of Stage IV remained consistently high, usually between 40 and $60 \%$ of the total catch. It is obvious that the majority of these copepodites 
were not completing their development but were accumulating to form the autumn stock. In Calanus (Nicholls, I933; Marshall et al., 1934) the stock in autumn consisted almost entirely of Stage V, and later observations are required to find out when Pseudocalanus moults into Stage V and adult. As shown in Fig. I the change to Stage V had been completed by mid-January, and a certain proportion had even become adult by then.

The increase in total numbers (Fig. 2) is very marked with the arrival of the second brood in the middle of April, and there is another great increase to the maximum for the year at the beginning of July. The number of copepodites on 3 July does in fact seem greater than can be accounted for by the comparatively small number of nauplii in the two previous weeks, considering the natural mortality which must be taking place all the time. It is possibly an instance of the uneven distribution of plankton which must always be taken into account in this type of work. There is another increase in total numbers in the second half of August following the increase in nauplii then. It consisted mainly of copepodites, Stages I, II and III being abundant as well as IV.

The relation of the first brood to the spring diatom increase has already been pointed out. The April increase in copepod numbers came just at the end of this spring maximum, which, although it was much poorer than usual, continued for over a month. The second great increase in copepod numbers was accompanied by a shorter diatom maximum composed, like the spring one, of Skeletonema costatum. During the period when Pseudocalanus numbers were at their maximum there were several outbursts of diatom growth, although the predominant species were then Chaetoceros spp. and Leptocylindrus sp. On the other hand, a marked diatom maximum from 22 May to 5 June (again mainly Skeletonema) was not followed, as one might have expected, by an increase in copepods.

Pseudocalanus shows several interesting points both of resemblance to and of difference from Calanus in its breeding cycle. Both had a first brood, very small in numbers, beginning to develop in March about the time of the spring diatom increase. The next brood appeared earlier in Pseudocalanus than in Calanus, and whereas that of Calanus did not develop, that of Pseudocalanus did. It is possible that the diatoms, abundant in the first half of April only, may have accounted for this.

Calanus had much more distinct breeding periods than Pseudocalanus; between its successive broods egg production died away almost completely, whereas in Pseudocalanus the proportion of eggs and nauplii remained comparatively high till July and breeding and development were probably continuous. In Pseudocalanus the building up of a winter stock began in July, and it consisted in October of Stage IV; in Calanus the building up did not begin till mid-August and it passed the winter as Stage V.

In the Loch Striven hauls a number of Pseudocalanus eggs were found free, but the majority were in egg-sacs, most often attached to the genital segment 
of the female. In the North Sea and English Channel, Pseudocalanus does not normally carry an egg-sac, ${ }^{\star}$ although two or three eggs are sometimes found attached to the genital segment. Fish (1936b) also states that in the Gulf of Maine the female is found only occasionally carrying two or three eggs. Sars (1903, Pl. X) figures the female $P$. elongatus with an egg-sac containing about seven or eight eggs and says in the text: 'Ovisac present of irregular rounded form but easily detached and containing a very limited number of ova.' In his figure of P. gracilis (Supplement, Pl. I), which, according to With (1915), is the same as P. minutus, the egg-sac is shown with twenty or more eggs. This variation in number is, however, within the range found in Loch Striven specimens. Females there were sometimes found with only two or three eggs attached, but it was assumed that these were in the act of laying, or had lost the main portion of the sac and they were counted as 'free' eggs.

Fish (1936b) says that to account for the large numbers of free eggs in the plankton each female must lay several hundred eggs. Since this seems, on the Loch Striven figures, too large a number for a single laying, each female may spawn several times, as has been suggested for Calanus (Marshall et al., I934).

The eggs in each egg-sac were counted throughout the year in order to estimate the average number laid by one female at a time and the seasonal variation. The average number varied considerably (Fig. 3), rising gradually from 9.5 on I3 February, to a maximum of 38.4 on I7 April. After this there was a gradual fall, interrupted by several very small increases, to a minimum of 8.0 on II September. The highest numbers occurred during the spring diatom increase and for a week or two afterwards; the slight interruptions of the downward curve are probably not significant, although they occur on, or just after, the dates of the secondary diatom maxima. It is not surprising that a well-fed copepod should produce more eggs than a starved one, but the variation seems to be dependent rather on the size of the female Pseudocalanus. The correlation between size of females (Fig. I6) and number of eggs is highly significant (0.98; 30 pairs of observations).

The free eggs were also counted and, assuming that the average number per egg-sac on each date holds for them also, it is possible to calculate the percentage of egg-bearing females present in any catch. This is a number, however, which shows violent fluctuations from week to week, and the variations do not seem to be related to any ascertainable factor. The maximum was $8 \mathrm{I} \%$ on I2 June, a date on which the number of eggs, although high, was not at its maximum.

The number of females carrying spermatophores was also counted in a sample from each catch (that used for measurement) and is shown at the top of Fig. I. The percentage was, with one exception, surprisingly low during the production of the first and second broods but was higher from April to June.

* Private communications from Mr R. S. Wimpenny, Lowestoft, and Mr P. S. B. Digby, Plymouth. 
It was above $10 \%$ only once, just before the appearance of the first brood females.

Males are usually much fewer than females in the catches, but this is probably because of their shorter life rather than because of any real discrepancy in actual numbers produced. When the proportions of the sexes are examined in copepodite Stages IV and V it is found that of the total number averaged over the year the percentage varies little from $50 \%$ of each (Table I, p. 57). In the early part of the year, however (January to March), the proportion of males in Stage V is only $35 \%$, although slightly over $50 \%$ in Stage IV. In several other species also males were scarcer during the early part of the year.

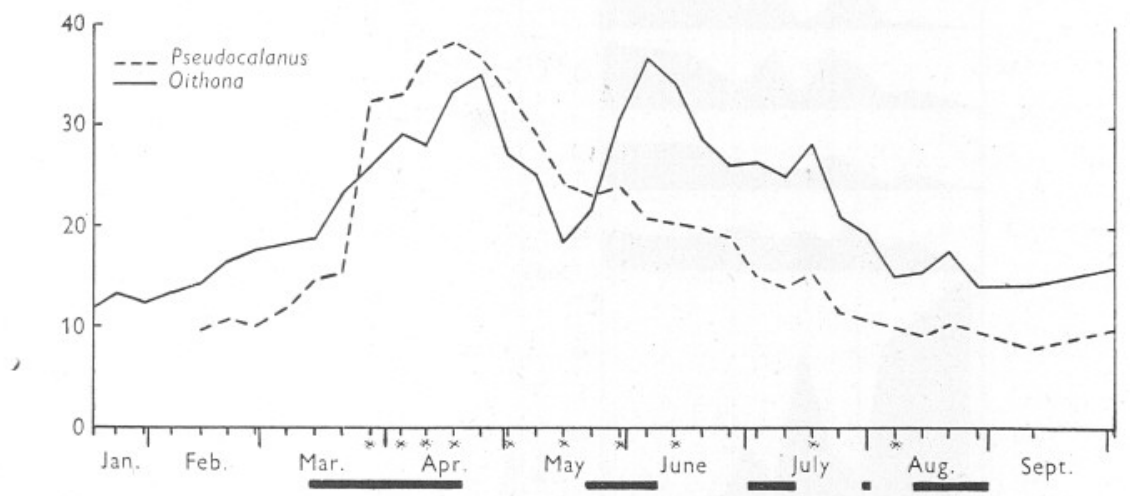

Fig. 3. Average number of eggs per female in Pseudocalanus and Oithona.

\section{Paracalanus parvus (Claus)}

(Table IV and Fig. 4)

Nauplii occurred throughout the year, but until July in small numbers only. Some of them were probably included among the Microcalanus nauplii, but they were separated from July onwards, and from the figures at that time it may be said that the percentage wrongly included is less than Io and probably less than 5. Only an occasional copepodite stage was seen before the middle of July, but from then till 2 October, when observations stopped, they increased steadily (Fig. 4). The maximum total number (more than half nauplii) came on 3I August, but copepodites were at their maximum on 2 October. However, the decreasing proportion of nauplii and the fact that the majority were Stage V and IV indicates that reproduction was over for the season and that, like Calanus and Pseudocalanus, Paracalanus passes the winter in a late copepodite stage. No distinct broods can be made out and breeding was probably continuous during the period of observation.

The percentage of males was low, only $13.5 \%$. Paracalanus females, like those of Pseudocalanus, sometimes show abnormalities of the fifth leg. Several 
specimens were seen in which it was four-segmented and not two-segmented as normally.

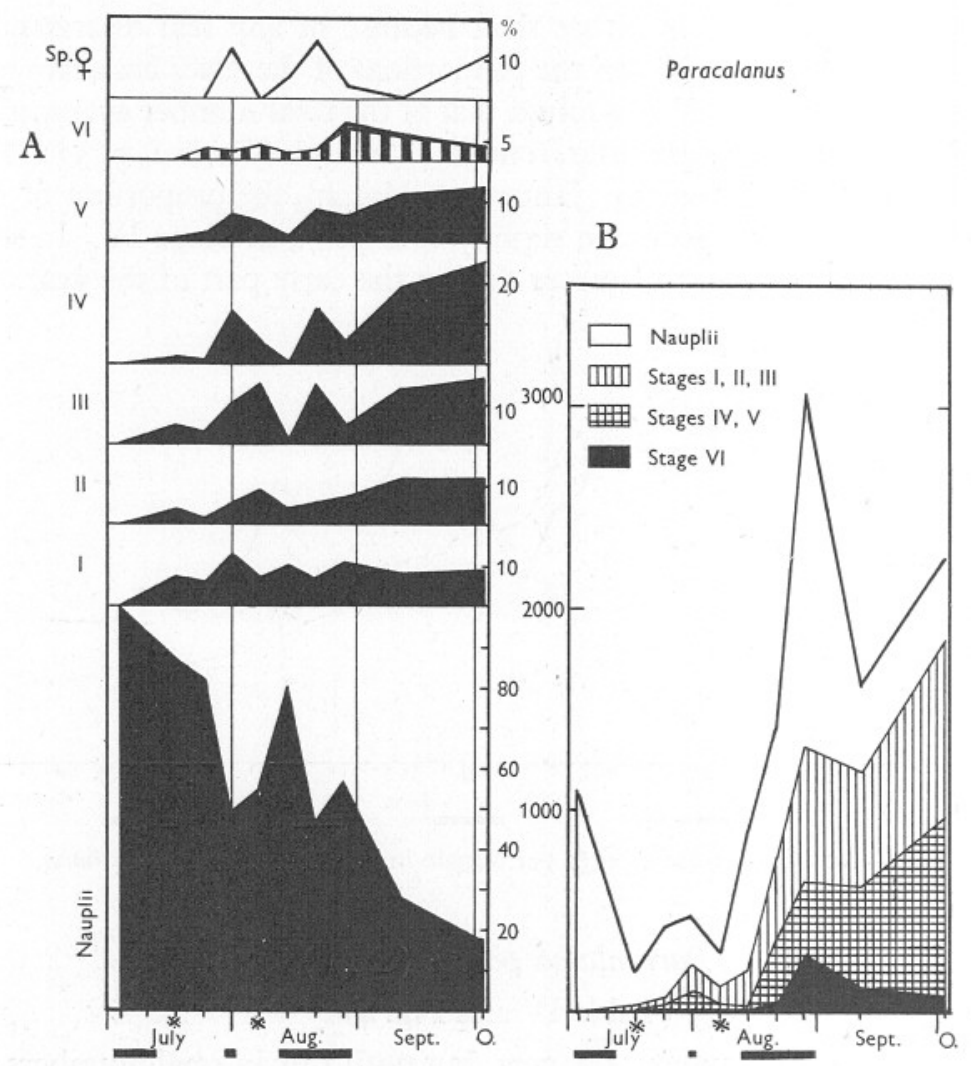

Fig. 4. Paracalanus parvus. A. Diagram showing the percentage of the developmental stages from July to October. The percentage of adult females with spermatophores is shown at the top. B. Total number per haul from July to October.

\section{Microcalanus pygmaeus G. O. Sars}

(Table V and Figs. 5 and 6)

This species differs from Pseudocalanus and Paracalanus and resembles Calanus in that it has well-marked breeding periods between which the proportion of nauplii and young stages falls to a low figure (Figs. 5, 6). It differs from all the other copepods studied in having its first breeding period well before the date of the spring diatom increase. When observations began (I7 January) nauplii formed nearly $70 \%$ of the catch, and the remaining $30 \%$ was fairly evenly divided among all the copepodite stages. These nauplii, and the later nauplii found in February, grew up to adults during February and 
March, and the second brood, beginning with a great increase in nauplii, came at the beginning of the spring diatom increase in March-April, and reached the adult stage in the beginning of May. Nauplii formed between 80 and $90 \%$ of the catch during most of June; as in Calanus there seems to be a gap of several weeks between the time the adults appear and the time of

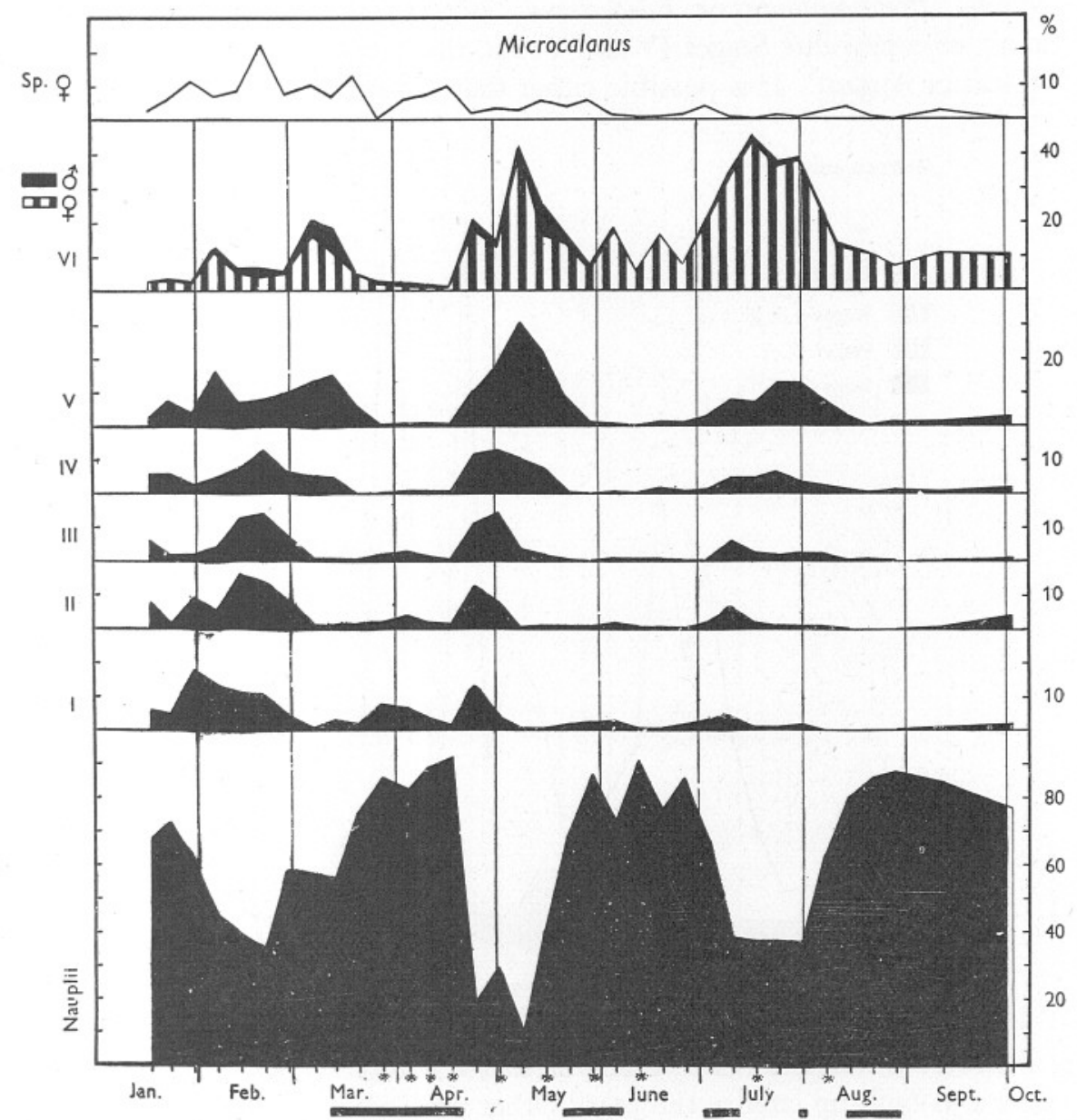

Fig. 5. Microcalanus pygmaeus. Diagram showing the percentage of the developmental stages during the year. The percentage of adult females with spermatophores is shown at the top.

maximum egg production as indicated by the number of nauplii; the eggs of this species were not counted. Diatoms were abundant at the end of May and again at the beginning of July, and it seemed to be mainly the later-produced of the June nauplii that grew up to form the third brood. The production of a brood in January, however, indicates that Microcalanus is less dependent on phytoplankton than the other species. 
The July peak of adults was followed in the last half of August by another steep rise in nauplii, which, although the actual numbers were much lower than in summer, made up as large a proportion of the catch. When observations stopped in October nauplii were still the most abundant stage ( $77 \%$ ), with adult females next. This is a very different state of affairs from that found in Calanus, Pseudocalanus or Paracalanus, where the winter stock consisted mainly of copepodite Stages IV and V, and that stock was already built up by the end of August. It is possible either that Microcalanus went on breeding

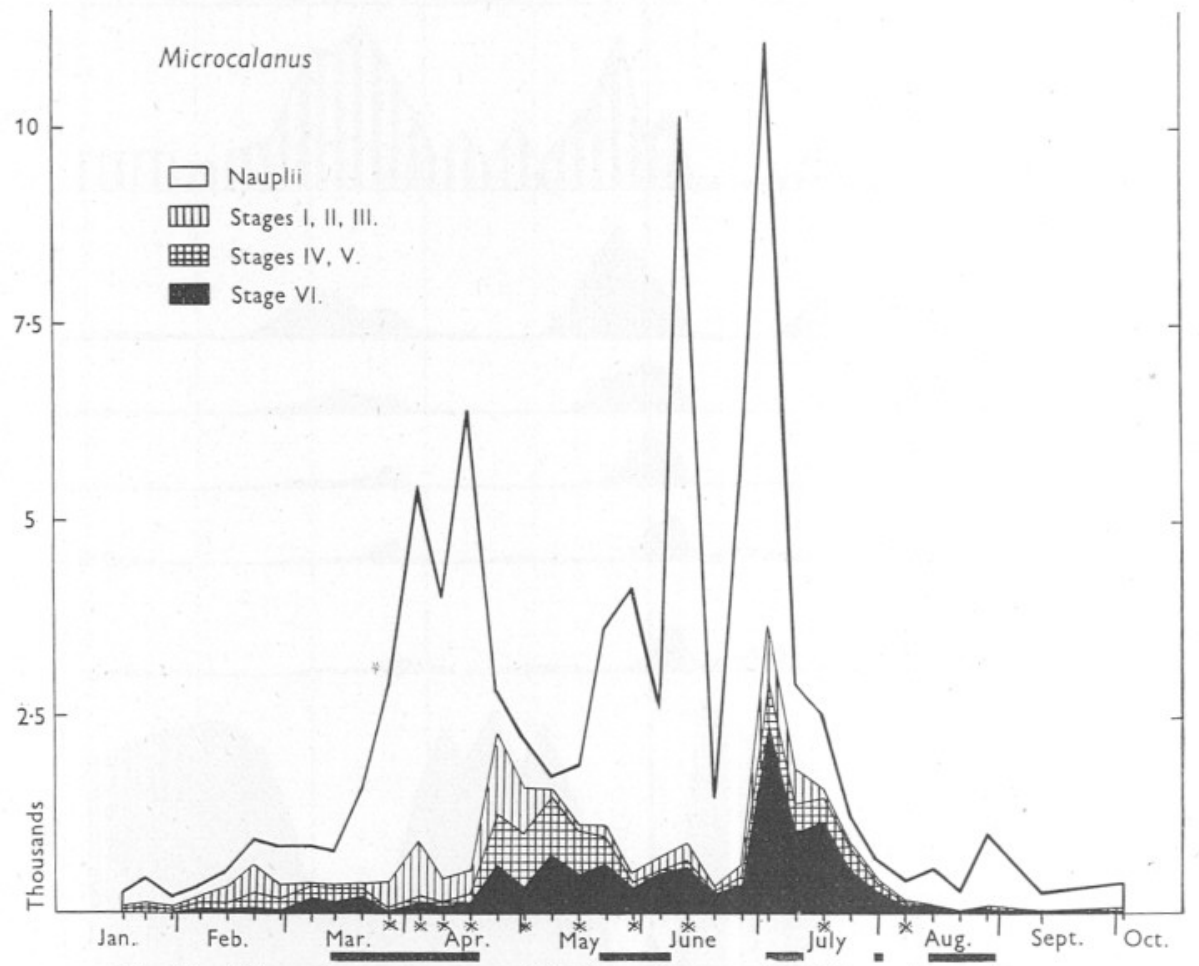

Fig. 6. Microcalanus pygmaeus. Total number per haul throughout the year.

at intervals throughout the winter, or that a winter stock of late copepodite stages was built up later in the year. Other possibilities are that Microcalanus passed the winter mainly in the nauplius or in the adult female stage. Observations during the winter are needed to decide which of these is correct.

On account of the very early first brood the total numbers of Microcalanus rose before any of the other copepods except Oithona became abundant. Already in February and the beginning of March the total number was nearly a thousand per haul compared with the two or three hundred Pseudocalanus present at that time. There were two maxima during the year, one in April, and one June to July, both consisting mainly of nauplii, but the second also 
the maximum for copepodites and adults. The second and larger maximum was interrupted by a sharp fall in nauplius numbers on 19 and 26 June.

The relative proportions of the different stages showed some peculiarities. There was evidently a high mortality among nauplii, which is only to be expected and is shown in most copepods. From May onwards, however, the normal proportions of the copepodite stages were reversed, and the adult females and also Stage $\mathrm{V}$ were in general more numerous than the younger stages. Perhaps this indicates a longer life for females and Stage $V$ than in the early part of the year, and gives some slight support to the suggestion that adult females may survive the winter. Adult males were always scarcer than females (although equally numerous in Stages IV and V) and became much more so after May. From January to May the percentage of males among the adults was about 23, from June to September it dropped to about 4 (Table I).

The proportion of females carrying spermatophores was highest in the early part of the year, but bore no apparent relation to broods (Fig. 5).

\section{Table I. Percentage of Males Present}

\begin{tabular}{|c|c|c|c|c|c|}
\hline Species & Stage IV & $\begin{array}{c}\text { V } \\
\text { Jan.-Oct. }\end{array}$ & $\begin{array}{c}\text { VI } \\
\text { Jan.-Mar. }\end{array}$ & $\begin{array}{c}\text { VI } \\
\text { Jan.-Oct. }\end{array}$ & $\begin{array}{l}\text { Otten } \\
\text { (1913) }\end{array}$ \\
\hline Calanus & - & - & $17 \cdot 3$ & $34 \cdot 3$ & - \\
\hline Pseudocalanus & $47 \cdot 7$ & $50 \cdot 2$ & II $\cdot I$ & $23 \cdot \mathrm{I}$ & $18 \cdot 3$ \\
\hline Paracalanus ${ }^{\star}$ & $45^{\circ} \circ$ & $40 \cdot 3$ & - & 13.5 & I6. 4 \\
\hline Microcalanus & $49 \cdot 2$ & $52 \cdot 8$ & $29 \cdot 4$ & II 2 & - \\
\hline Centropages & - & $56 \cdot I$ & -1 & 63.8 & $20 \cdot 7$ \\
\hline Temora & $49 \cdot 9$ & $55 \cdot 7$ & - & $57 \cdot 8$ & $20 \cdot 7$ \\
\hline Acartia & $46 \cdot 5$ & $45 \cdot 7$ & $7 \cdot 7$ & $48 \cdot 3$ & $5.3 \dagger$ \\
\hline Oithona & & & $2 \cdot I$ & $12 \cdot 8$ & $4 \cdot 6$ \\
\hline
\end{tabular}

Centropages hamatus (Lilljeborg) and Temora longicornis (Müller) (Tables VI and VII, Figs. 7-10)

Breeding is so similar in these two species that they may be taken together. From January until the middle of March the stock, apart from an occasional early copepodite, was represented entirely by nauplii. These were few in number, rising from Io or 20 in January to IOO or 200 in March. In March. copepodites appeared in numbers for the first time, a little earlier in Temora than in Centropages, and in the following weeks this first brood grew to maturity to reach the adult stage in April. It may be noted that the spring diatom increase began on I3 March and lasted till the middle of April. In the middle and second half of April, nauplii again predominated, and a second brood grew up during late April and May (Temora) or May (Centropages), reaching the adult stage about Io and 22 May respectively. At this time diatoms were not abundant. Another great increase of nauplii in both species causing the maximum numbers of the year for Centropages (I900 per haul) coincided with the next diatom increase, but apparently no brood developed from these 
nauplii. A marked increase in the proportion of adults in Centropages and of adults and copepodites in Temora on I9 June (Figs. 7, 9), seen in Acartia and Oithona also, was caused by a sudden drop in the number of nauplii, since the actual numbers of the older stages remained constant or even fell. The fourth

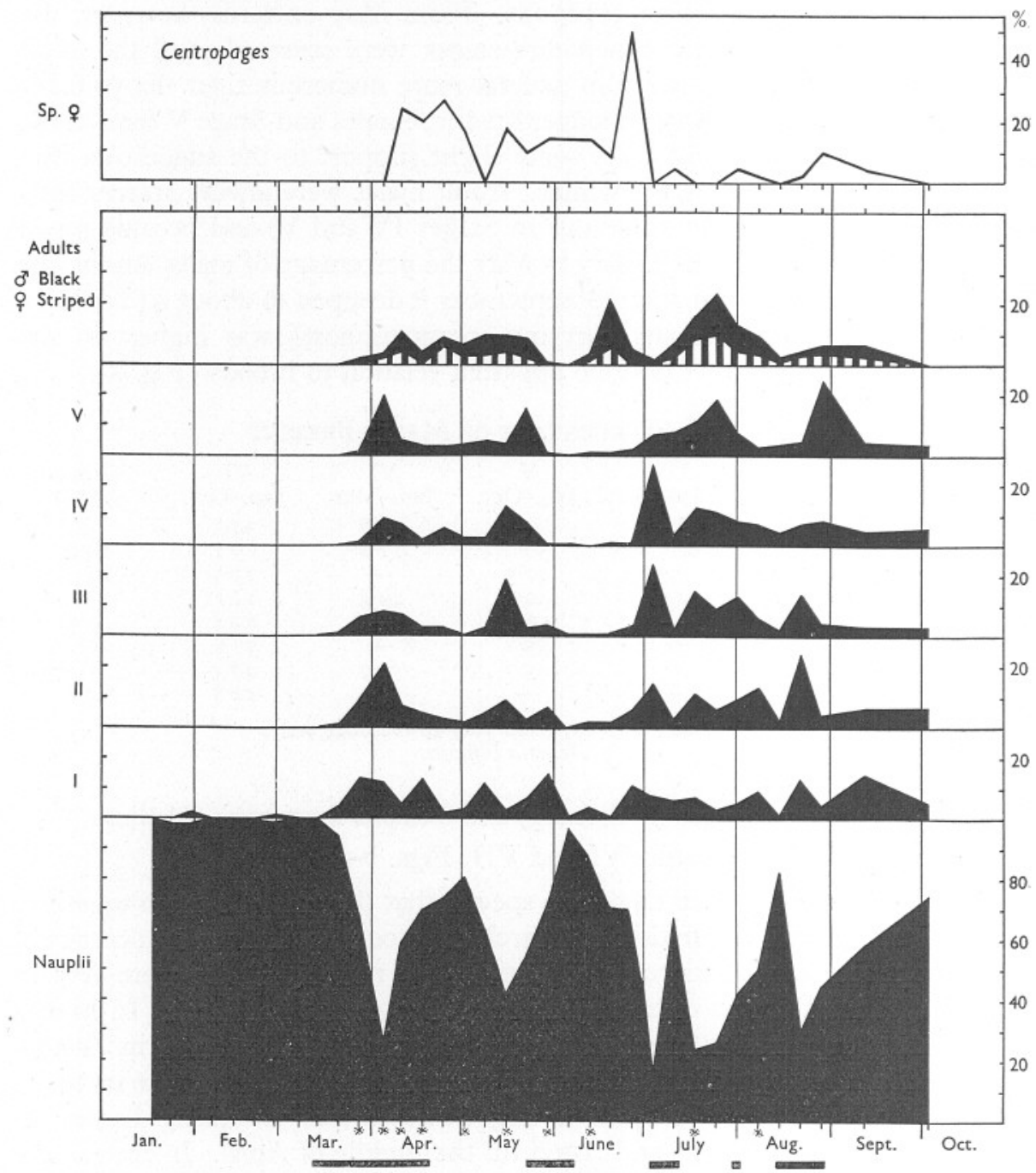

Fig. 7. Centropages hamatus. Diagram showing the percentage of developmental stages during the year. The percentage of adult females with spermatophores is shown at the top.

brood, marked only in Centropages, developed from nauplii produced at the end of June, and during July and August breeding in both species seemed to be continuous. In Centropages the last distinct brood reached maturity at the end of August, and when observations stopped in October three-quarters of 
the catch was nauplii and the remaining quarter was fairly evenly divided among Stages I-V. In Temora there was no distinct August brood, but in October the distribution was much the same as in Centropages, nearly $70 \%$ of the stock being nauplii. This is a very different distribution from that found at the end of the winter, and it is possible that breeding can go on later in the year. Otten (I9I3), however, mentions that in his catches (in Kiel Bay) there were at the end of September and in November large numbers of Centropages nauplii with no corresponding copepodites. The nauplius seems an unlikely stage in which to pass the winter (cf., however, Microcalanus), and it is possible that adults survived in small numbers, living so near the bottom that the

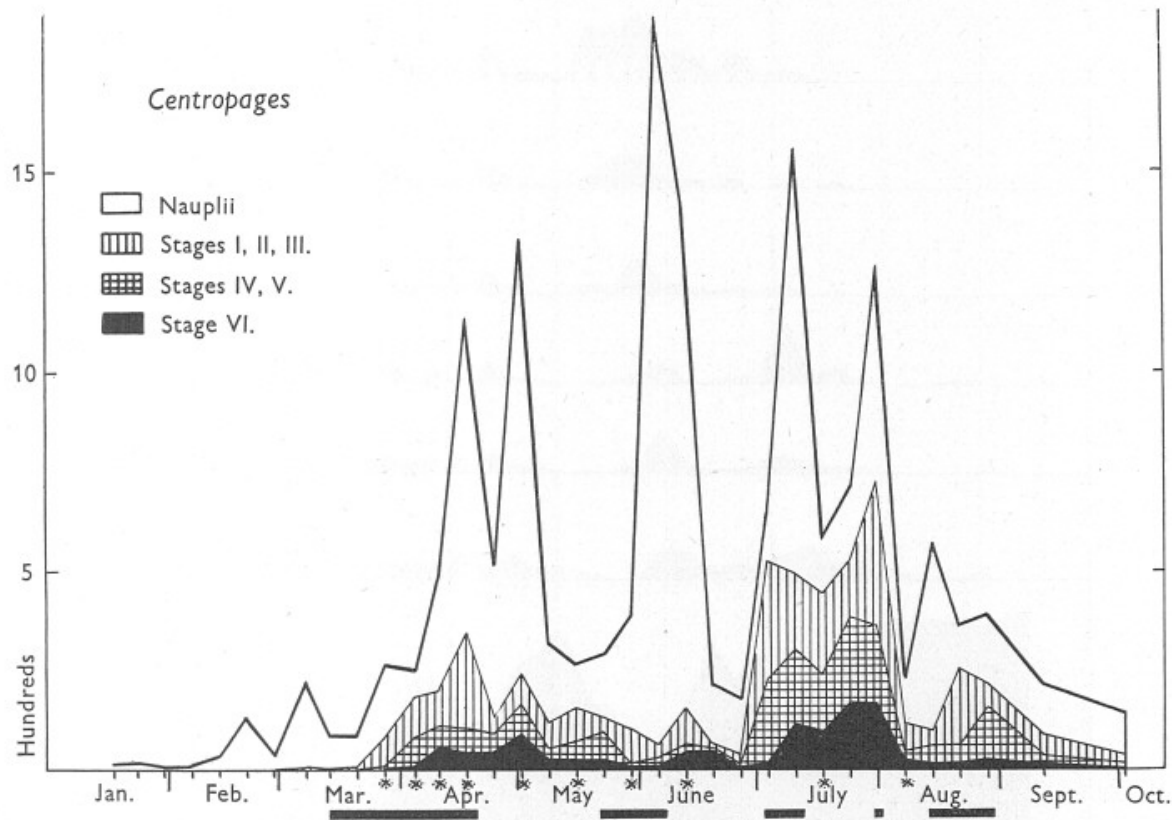

Fig. 8. Centropages hamatus. Total number per haul throughout the year.

vertical tow-net did not catch them, and producing a small number of eggs and nauplii throughout the winter. Another possibility is that some sort of resting egg is produced which can survive for long periods (see Fish \& Johnson, I937, p. 307).

Otten (1913) mentions Temora as carrying an egg-sac with four to eight eggs and says the sac breaks up readily. No sign of a sac was ever seen on the female Temora in Loch Striven.

Nauplii were responsible for most of the peaks in numbers during the summer (Figs. 8, IO), since they often formed over $70 \%$ of the catch of Centropages and even more in Temora. In both species there were maxima of copepodites and adults in April at the time of the first brood and in July with 
the third or fourth. In Centropages the numbers in July were the higher (700 copepodites and adults per haul on 3I July) and in Temora the April to May numbers (500 per haul on I May).

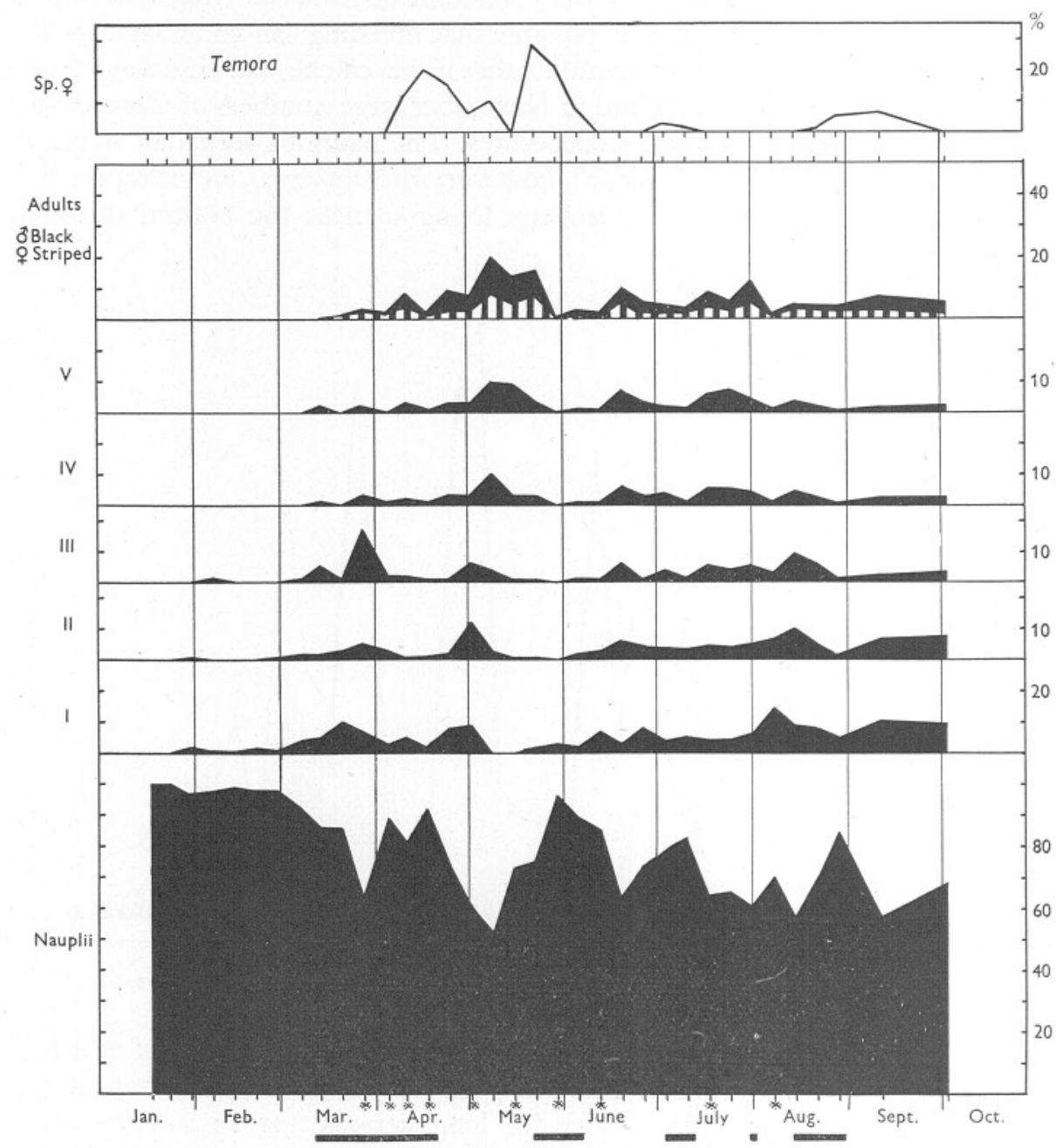

Fig. 9. Temora longicornis. Diagram showing the percentage of development stages during the year. The percentage of adult females with spermatophores is shown at the top.

Centropages and Temora differ from the other species of copepod examined in that males are more abundant than females throughout the year' (Table I, p. 57). This was true also in the Nordåsvatn Fjord near Bergen (Wiborg, 1944). Even in Stage V there was a slight tendency for males to be more numerous. Taking the average over the year males formed $64 \%$ of the Centropages 
adults and $58 \%$ of the Temora adults. In Stage V they formed $56 \%$ in both species. In spite of this the number of females carrying spermatophores, although higher than in Pseudocalanus and Microcalanus, was lower than in Acartia, where the sexes were about equal, or in Oithona where males formed

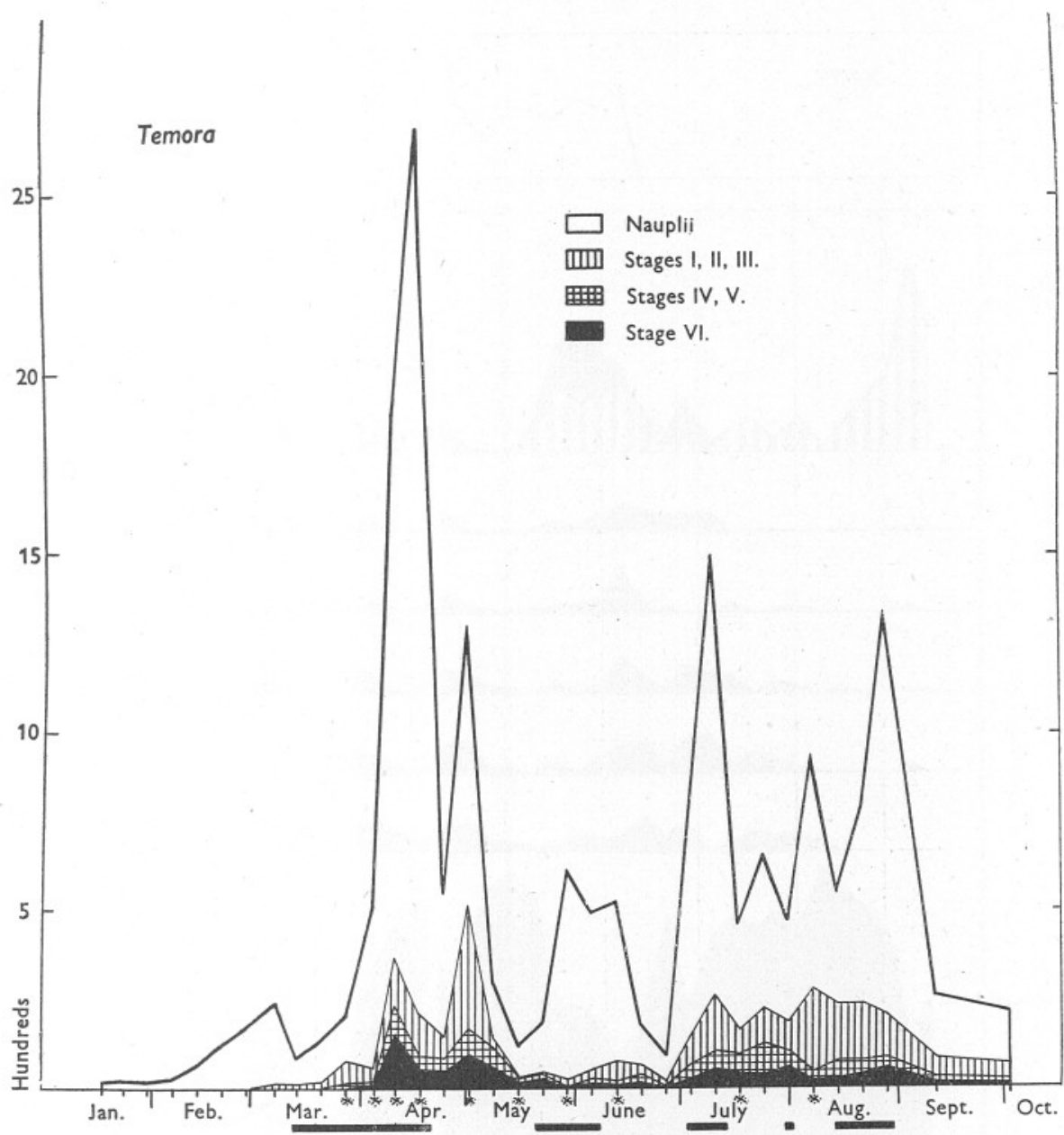

Fig. 1o. Temora longicornis. Total number per haul throughout the year.

only I3 \%. The number of spermatophore-bearing females is shown at the top of Figs. 7 and 9, and it is on the whole highest on the appearance of the first brood and varies irregularly throughout the summer. The peak in Centropages on 26 June means little, for only two females were caught, one with a spermatophore. 


\section{Acartia clausi Giesbrecht}

(Table VIII, Figs. II and I2)

The stock of Acartia in January, unlike the other species examined, consisted almost entirely of adult females and nauplii. In February and March

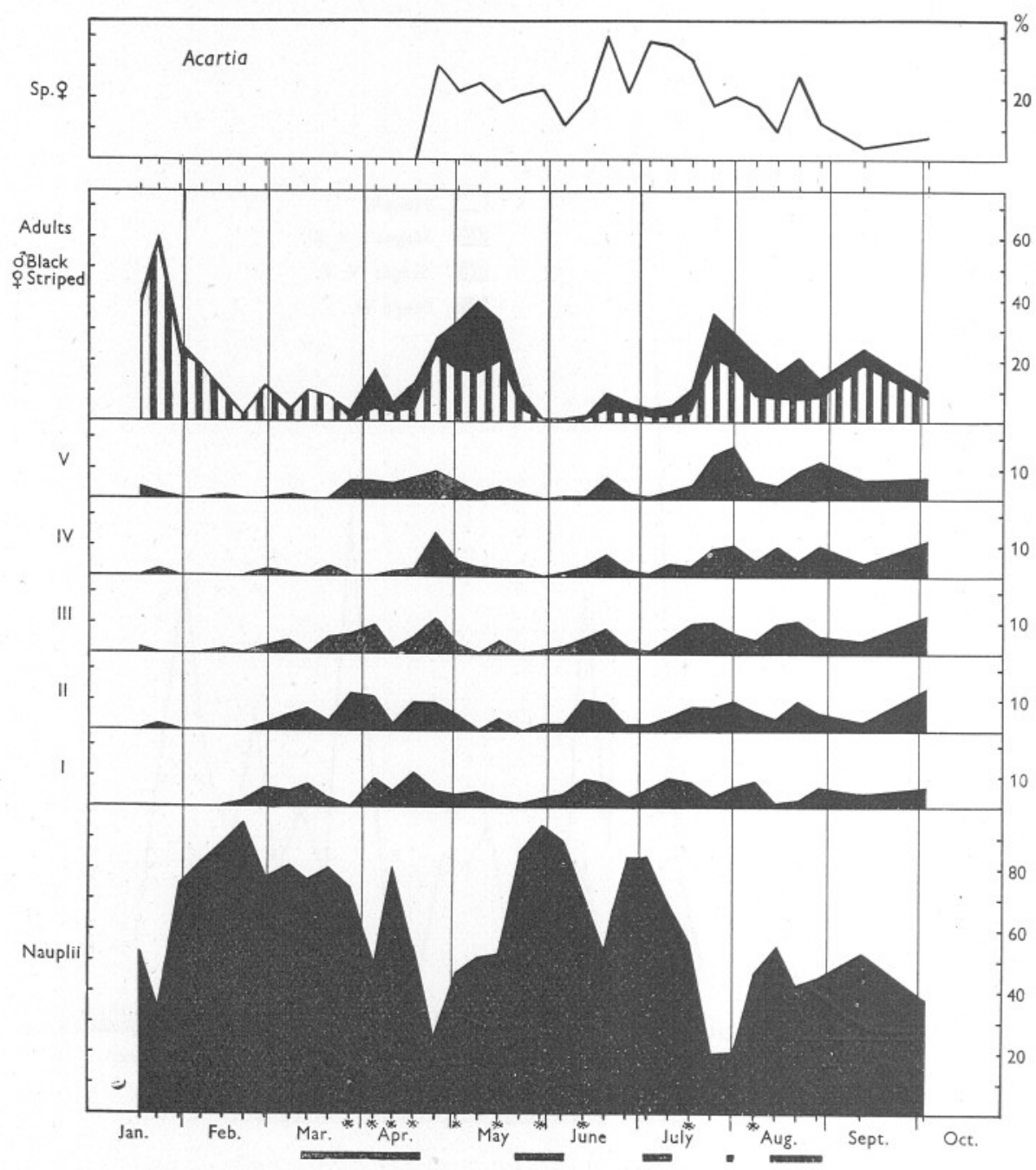

Fig. Ir. Acartia clausi. Diagram showing the percentage of developmental stages during the year. The percentage of adult females with spermatophores is shown at the top.

nauplii predominated, and in the latter half of March (along with the spring diatoms) the first brood grew up. The period of reproduction was rather spread out, or else there were two broods in close succession, of which the second 
came to maturity at the beginning of May. The numbers at this time were, however, very small and hardly show in Fig. I2.

Another peak in nauplius production came with the diatom increase at the end of May, and this brood began to grow up during June. It is difficult to follow it to maturity, however, because of the sudden change (already mentioned) on I9 June in the proportions of nauplii and late copepodites.

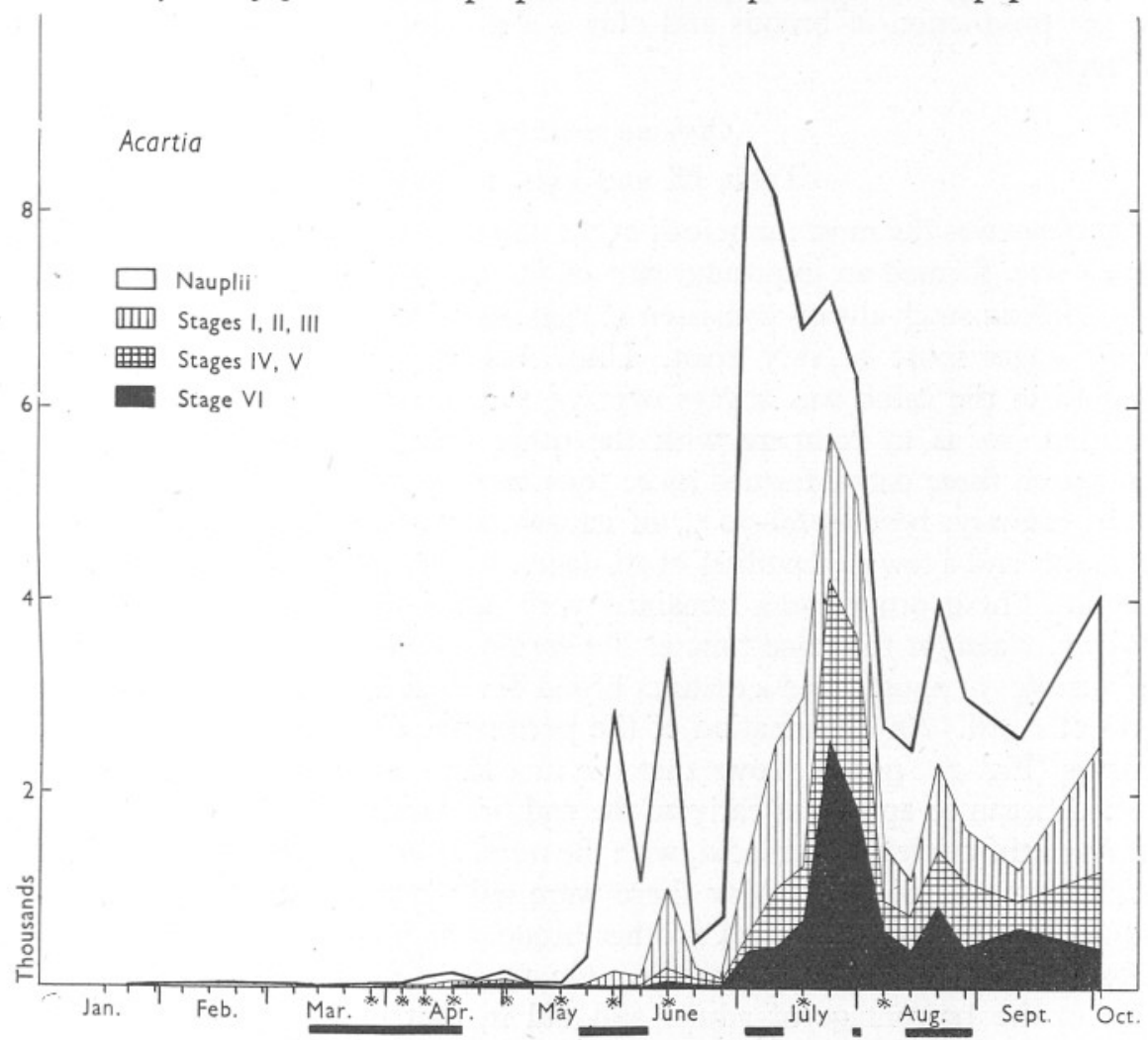

Fig. I2. Acartia clausi. Total number per haul throughout the year.

The peak in nauplius production at the beginning of July coincided with a diatom increase, and a brood, the third or fourth, developed during the month and reached the adult stage at the end of July and beginning of August. After this, breeding seemed to be continuous and the number of copepodites and adults remained high. When observations stopped in October there were less than $40 \%$ of nauplii and the other $60 \%$ was fairly evenly distributed among the different copepodite stages, so that in Acartia, too, it is possible that breeding may go on well into the winter.

The maximum number for the year occurred in July, as nauplii at the beginning of the month and as copepodites and adults (5000 per haul) at the end. 
Taken over the year the sexes were almost equal in number in all stages where they are distinguishable (Table I, p. 57). Although among adults females predominated up to April and after August, during the summer months males often outnumbered females. There were no females carrying spermatophores in January and February, but from the end of April the number was high, especially during June and July, but it seemed to have no relation to the production of broods and only a slight relation to the predominance of males.

\section{Oithona similis Claus}

\section{(Table IX and Figs. I3 and I4)}

Oithona was the most numerous of the small copepods, and so, in spite of its small size, formed an important part of the plankton. A large proportion of the Oithona stock always consisted of eggs and nauplii; the mortality in these early stages must be very great. Until August the percentage of eggs and nauplii in the catch was always over 75 and often over 90. When eggs are omitted (so as to compare with the other copepods studied) the nauplii, except on three dates, formed more than half the catch.

In January, besides $60-70 \%$ of nauplii the stock contained nearly $20 \%$ of adults and a few copepodites of all stages, so that breeding may already have begun. These proportions remained very much the same until the end of March, when (at the same time as the spring diatoms) there was a rise in the percentage of nauplii and a distinct brood developed, reaching maturity at the end of April. An examination of the percentage size-frequency distribution curves (Fig. 29, p. 8I) shows that the first large adult females of the spring brood began to appear as early as the end of March. From then till the end of April the curves are bimodal, with the number at the larger mode increasing until on 24 April and I May there were only large females present. These adults immediately produced another brood which grew up during May, but after this breeding was continuous. On I9 June there was the same abrupt rise in the percentage of adults and fall in that of nauplii as occurred in Temora, Centropages and Acartia. From July onwards the proportion of nauplii was lower than during the earlier part of the year. When observations stopped, adults and copepodites formed $60 \%$ of the stock, and breeding may have continued throughout the winter.

Although Oithona was numerous throughout the year the numbers rose sharply only at the beginning of July, and the total stock (excluding eggs) on 3 July was I8,000 per haul. Numbers fell again to the beginning of August and then rose to the maximum for the year on $2 \mathrm{I}$ and 28 August when there were about 30,000 copepodites and nauplii, with 13,000 and 6000 eggs in successive weeks.

Males were always much scarcer than females, the discrepancy being most marked in early spring (Table I, p. 57). In January and March the males 
numbered only $2 \%$ of the adults, for the whole year $13 \%$. The number of females with spermatophores was about Io \% or less until April, but after this, with the higher proportion of males, it remained consistently high. The

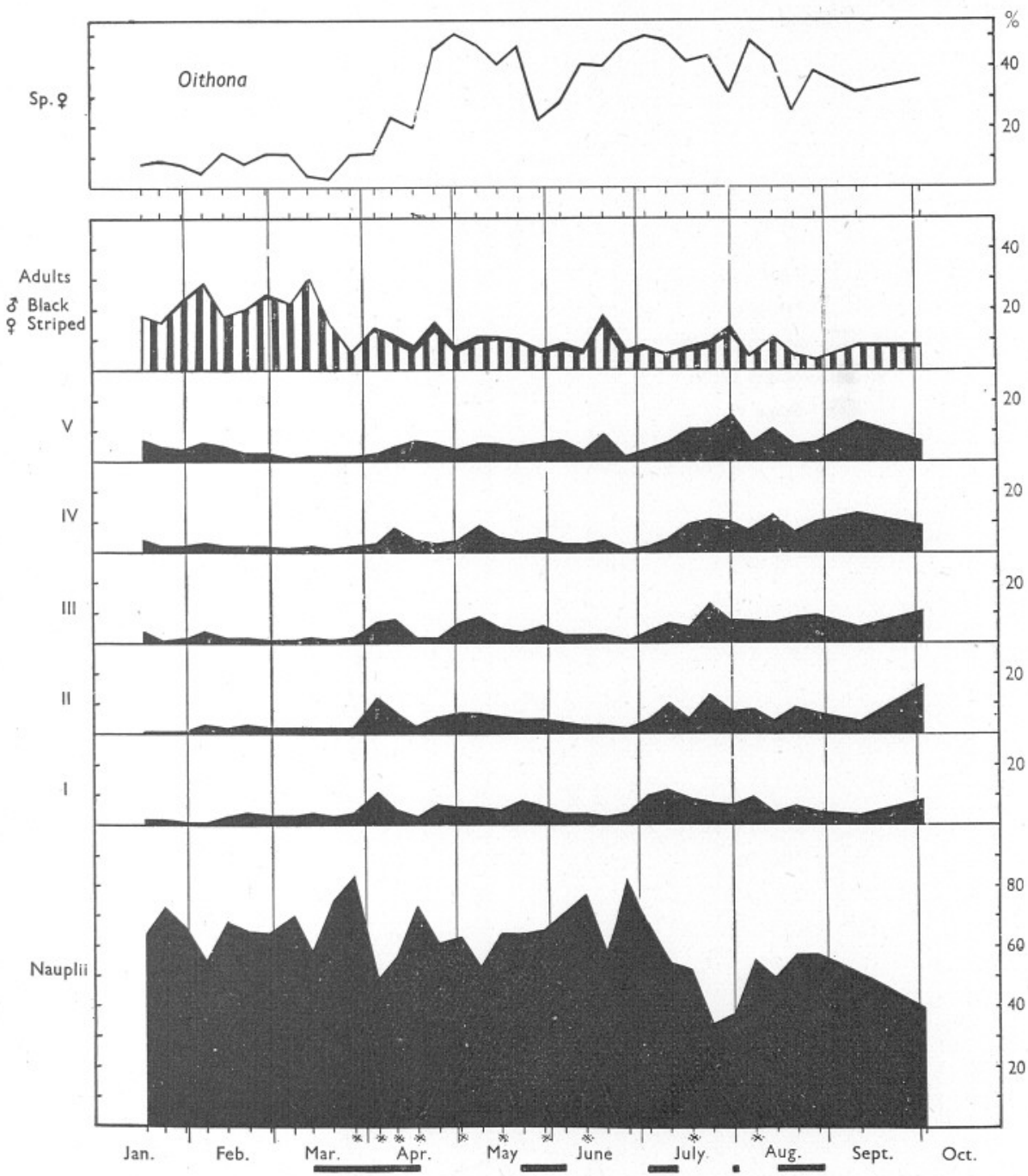

Fig. I3. Oithona similis. Diagram showing the percentage of developmental stages during the year. The percentage of adult females with spermatophores is shown at the top.

figure probably means little, however, for among the females carrying egg-sacs some had spermatophores and some had not (see p. 69).

The eggs are carried by the female in a pair of egg-sacs attached to the genital segment, so it is possible to count the number of eggs per sac and per 


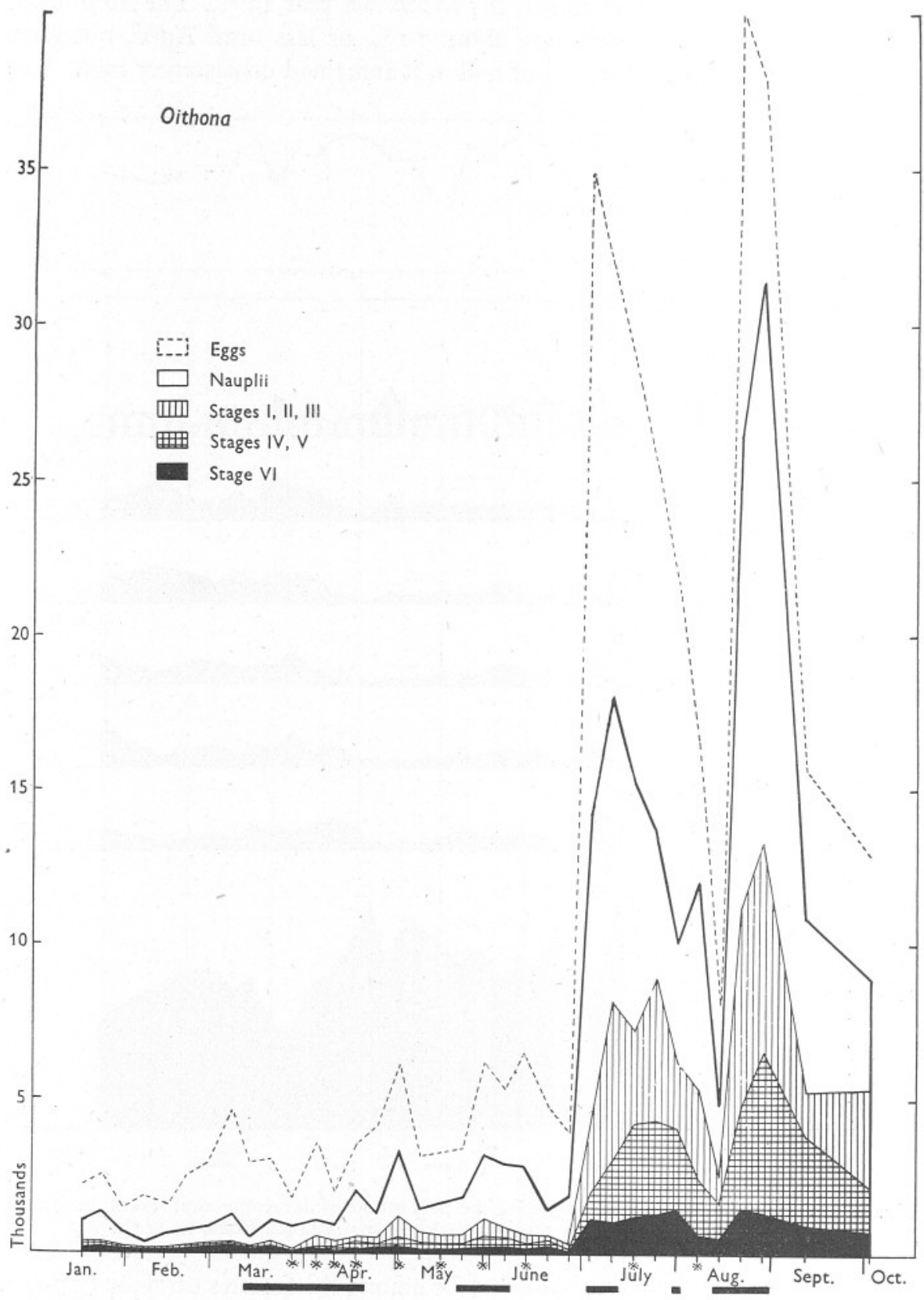

Fig. 14. Oithona similis. Total number per haul throughout the year. 
female, and the latter is shown in Fig.3 (p. 53). As in Pseudocalanus the number increased gradually to a maximum at the end of April, at the end of the spring diatom increase, when females were about their maximum size. There was then a rapid decrease in number until the middle of May, but from then till 5 June, unlike Pseudocalanus, there was a sharp rise to a second maximum. Thereafter numbers decreased gradually till the autumn, although there were two slight checks on the curve on the same dates as those found in Pseudocalanus.

The paired sacs did not always contain the same number of eggs, although they were usually nearly the same. The number per egg-sac varied from four to thirty-four, and almost the whole range might be covered in one catch. Over Ioo egg-sacs were usually counted.

The curves indicate that the relation between number of eggs and size of female is less close than in Pseudocalanus, although the correlation coefficient is still highly significant $(0.75,35$ pairs of observations). An examination of Figs. 3 and 28 shows that whereas egg numbers rose to a well-marked peak on 5 June the size of females showed only a slight rise at that time. Diatoms were abundant while the egg numbers were rising, and were scarce after 5 June, so that it is probable that the food supply has an effect on egg production. Diatoms were abundant also on the dates in July and August when the downward trend of egg number is checked, but the differences in egg number are not significant. Otten (I9I3) counted the number of eggs per sac and found that this varied throughout the year, being, like the nauplii, highest in April and October and lowest in August.

In considering the reproduction of the copepods as a whole, we can see that there are two types of breeding. In one the broods are distinctly separated by periods when eggs and nauplii are scarce. To this type belong Calanus and Microcalanus. In all the other copepods examined the broods were less distinctly separated and in the second half of the year were indistinguishable. In the second type there seems to be a shorter time between the appearance of adult females and the production of eggs and nauplii. In Calanus (Fish, I936a; Marshall et al., I934) the maturing of the eggs is supposed to take about 3-4. weeks, and the same seems to be true of Microcalanus. In the other copepods a peak in nauplius numbers followed more closely (in two or three weeks) upon the appearance of adults, and two broods might appear in quick succession. In the late summer when breeding was continuous, no gap could be distinguished (see, however, Fish, 1936b, on Pseudocalanus).

In Calanus the time occupied in development from egg to adult was estimated, partly from the data from the Loch Striven hauls and partly from laboratory experiments, at about a month. There are no laboratory data for the small copepods, and since visits to the loch were made only weekly, estimates must be uncertain, but the time seems to be little shorter than in 
Calanas. In most species the time from a peak in nauplius production to a peak of adults is $3-4$ weeks. The great differences between spring and summer mentioned by Fish (1936c) do not occur here.

In all species the spring diatom increase seems to have had an important effect on reproduction. Although Microcalanus and possibly Oithona were breeding before it, yet during or at the end of the diatom-rich period (which in 1933 was long-drawn out-I3 March to I7 April), every species showed an increase, in most of nauplii, and in all a successive development of early and late copepodites and adults. The date varied from one species to another between the middle of March and the middle of April. In Pseudocalanus and Acartia the actual numbers of the first brood were very small; in Microcalanus, Centropages and Temora they were considerable, especially when compared with the numbers occurring later in the year. In all species nauplii form a large proportion of almost every catch, and the greatest mortality must take place at this early stage. Fish $(1936 a, b)$ suggests that another dangerous period in the life of a copepod is during the maturing of the eggs, and that in Calanus the mortality is actually greatest at that stage, and is important also in Pseudocalanus.

The maximum number of all species of copepod except Temora, and sometimes Calanus (Nicholls, 1933), came during the summer, in July or August, but the date varied from species to species. This was true for the maximum numbers both of nauplii, and of copepodites and adults, which in Microcalanus and Oithona occurred on the same date. Besides this summer maximum there was usually a secondary maximum earlier in the year, in April or May, but this was smaller and more variable. In Acartia and Oithona it was small, in Temora it was more important than the summer maximum.

The proportion of the sexes varied among the different species, and it varies also from place to place. Otten (1913) gives figures for seven copepods (Table I, p. 57), mostly the same species as those in Loch Striven, but in his samples males were much scarcer. In both places, however, Oithona had the smallest, and Centropages and Temora the highest, proportion.

In Loch Striven (Table I) the percentage of males in Calanus, Pseudocalanus, Acartia and Oithona was lowest from January to March. In Calanus and Pseudocalanus it was highest from April to June, but in Acartia and Oithona the proportion did not vary much from April onwards. Centropages and Temora were too scarce before April for the number of males to be reliable, and after April the proportion remained fairly constant. In Microcalanis, on the other hand, their percentage was highest in April and was very low after June.

If, as seems most probable, these very varying proportions indicate the length of life of the adult, then in some species the female is the longer lived, in others the male. The length of life also varies at different times of the year, and this we already know to be true of some of the earlier stages such as Stages IV and V of the autumn stock of Calanus, Pseudocalanus and Paracalanus. 
In Calanus (Marshall et al., I934) the percentage of adult females carrying spermatophores was highest before the production of each brood of eggs, and it was observed that the spermatophore was usually lost before the eggs were ripe for spawning. No such relation was made out in the small copepods. In one species (Oithona similis) the spermatophore was often retained even after the eggs had been spawned, and this may be so in other species also. It is curious, too, that the very varying proportion of males seems to have little influence on the number of females carrying spermatophores.

\section{VerTiCAL Distribution}

From 27 March to 2I August one of the five hauls was taken in two parts, from the bottom $(60-70 \mathrm{~m}$.) to Io m., and from Io m. to the surface. It must, however, be remembered (see p. 46) that there may have been a considerable and variable loss from the bottom haul which means that the proportion of copepods below Io $\mathrm{m}$. may be greater than appears from the figures. It is felt that despite this disadvantage the results obtained are substantially true.

In Fig. I5 is shown for all stages of each species the percentage above and below Io $\mathrm{m}$. No allowance has been made for the much greater depth of water sampled below Io $\mathrm{m}$. It is felt that the copepods are very unlikely to be evenly distributed throughout the column, and there are in fact indications that they may have been confined to the top 20 or $30 \mathrm{~m}$. A series of samples taken at Io m. intervals from top to bottom would give a truer picture of their distribution.

It will be seen that from the end of March till the middle of June the great majority of all stages of all species except Microcalanus was above Io $\mathrm{m}$. There was then a rapid descent, and in July most stages of all species were wholly or largely below Io m. In August there was a gradual rise again in most species, more marked in the younger stages, but when observations stopped on 2 I August the distribution had not yet returned to the state shown at the end of March.

Although this gives a general picture of the copepod distribution, there was considerable variation in detail between the different species and the different stages of the same species. Microcalanus was unlike any of the others, since during almost the whole year all stages remained consistently below Io $\mathrm{m}$. On 22 and 29 May the proportion of Stages II and III above IO m. increased, but the numbers then present were too small to be significant, and on the last two dates in August Stages I and II were absent altogether. The rise of the nauplii in August, however, was based on considerable numbers and seems to be real. On the first two dates, $27 \mathrm{March}$ and 4 April, a considerable proportion of all stages except males and nauplii was found above ro m., and this may mean that there is a period during the winter when Microcalanus, like the other copepods, lives mostly near the surface. Further observations are needed to 


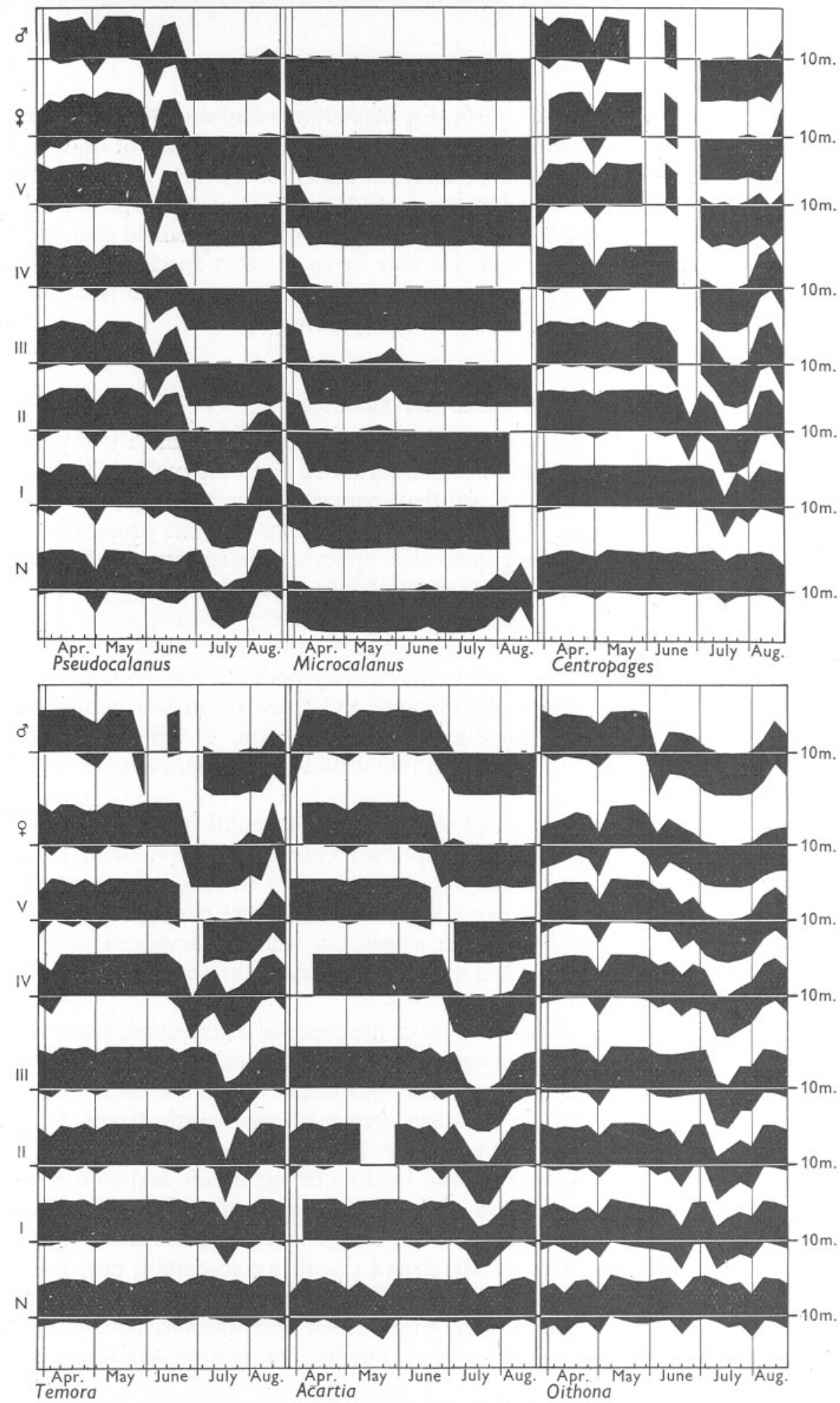

Fig. 15. Diagram showing the percentage of copepods above and below Io $\mathrm{m}$. from $27 \mathrm{March}$ to 2I August. The nauplii and copepodite Stages I-VI are shown separately for each species. 
the catch was nauplii and the remaining quarter was fairly evenly divided among Stages I-V. In Temora there was no distinct August brood, but in October the distribution was much the same as in Centropages, nearly $70 \%$ of the stock being nauplii. This is a very different distribution from that found at the end of the winter, and it is possible that breeding can go on later in the year. Otten (I9I3), however, mentions that in his catches (in Kiel Bay) there were at the end of September and in November large numbers of Centropages nauplii with no corresponding copepodites. The nauplius seems an unlikely stage in which to pass the winter (cf., however, Microcalanus), and it is possible that adults survived in small numbers, living so near the bottom that the

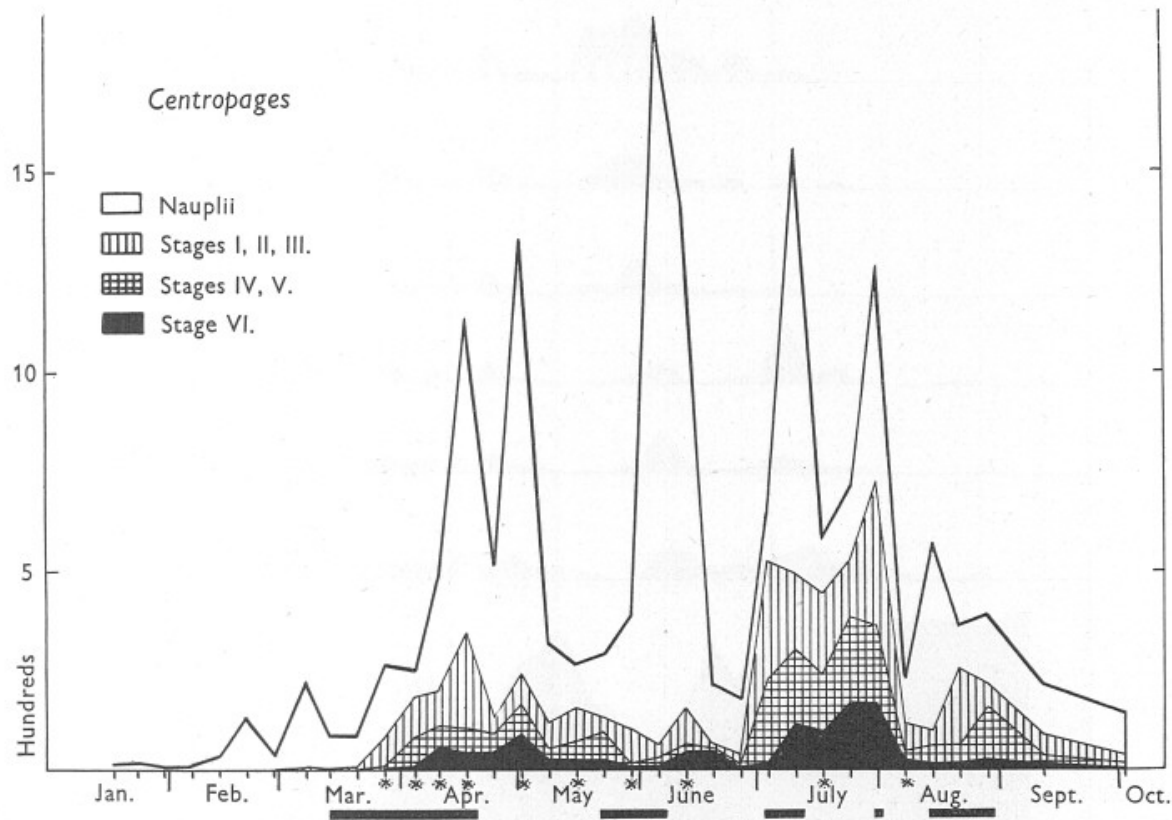

Fig. 8. Centropages hamatus. Total number per haul throughout the year.

vertical tow-net did not catch them, and producing a small number of eggs and nauplii throughout the winter. Another possibility is that some sort of resting egg is produced which can survive for long periods (see Fish \& Johnson, I937, p. 307).

Otten (1913) mentions Temora as carrying an egg-sac with four to eight eggs and says the sac breaks up readily. No sign of a sac was ever seen on the female Temora in Loch Striven.

Nauplii were responsible for most of the peaks in numbers during the summer (Figs. 8, IO), since they often formed over $70 \%$ of the catch of Centropages and even more in Temora. In both species there were maxima of copepodites and adults in April at the time of the first brood and in July with 
the third or fourth. In Centropages the numbers in July were the higher (700 copepodites and adults per haul on 3I July) and in Temora the April to May numbers (500 per haul on I May).

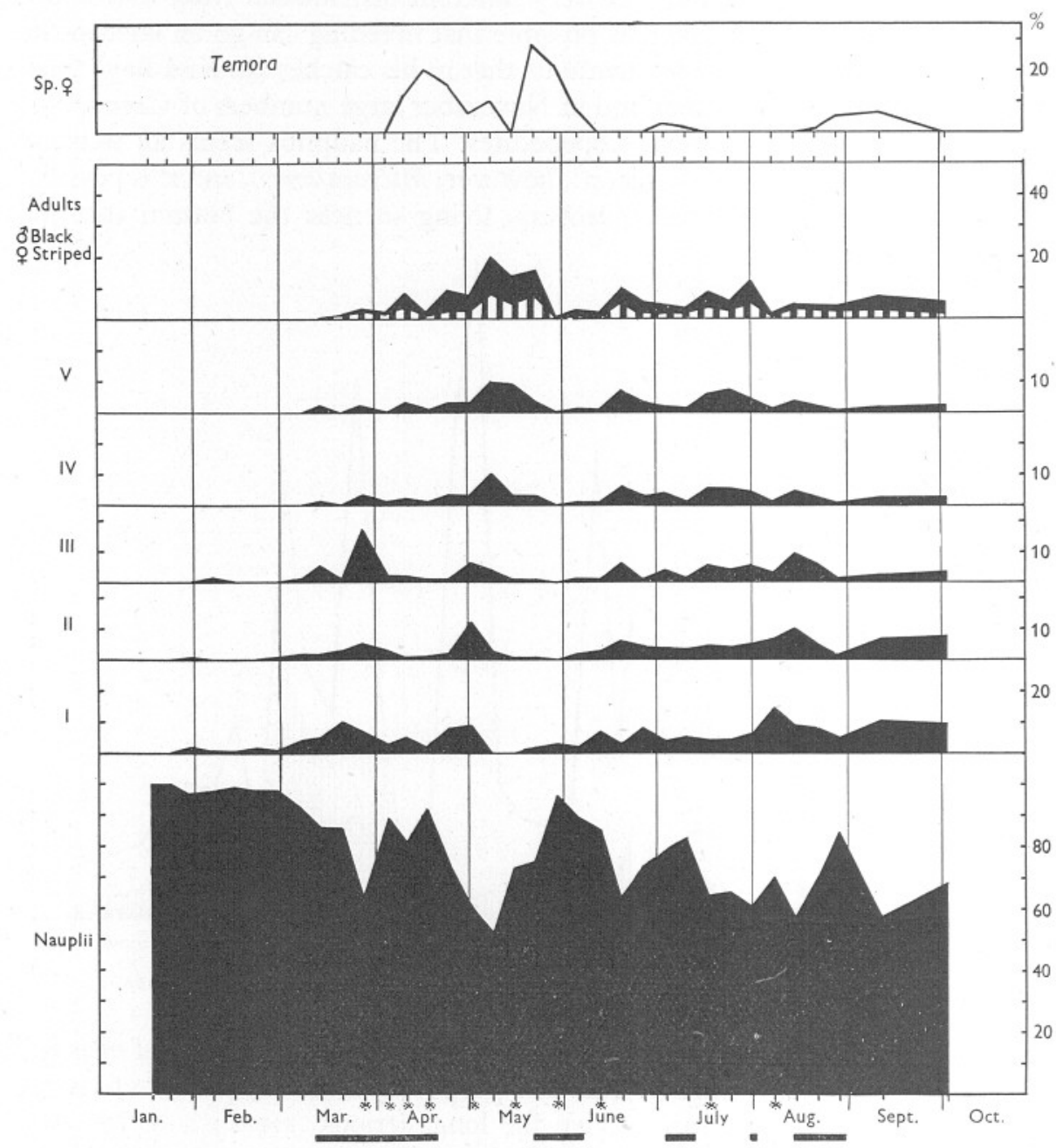

Fig. 9. Temora longicornis. Diagram showing the percentage of development stages during the year. The percentage of adult females with spermatophores is shown at the top.

Centropages and Temora differ from the other species of copepod examined in that males are more abundant than females throughout the year' (Table I, p. 57). This was true also in the Nordåsvatn Fjord near Bergen (Wiborg, 1944). Even in Stage V there was a slight tendency for males to be more numerous. Taking the average over the year males formed $64 \%$ of the Centropages 
adults and $58 \%$ of the Temora adults. In Stage V they formed $56 \%$ in both species. In spite of this the number of females carrying spermatophores, although higher than in Pseudocalanus and Microcalanus, was lower than in Acartia, where the sexes were about equal, or in Oithona where males formed

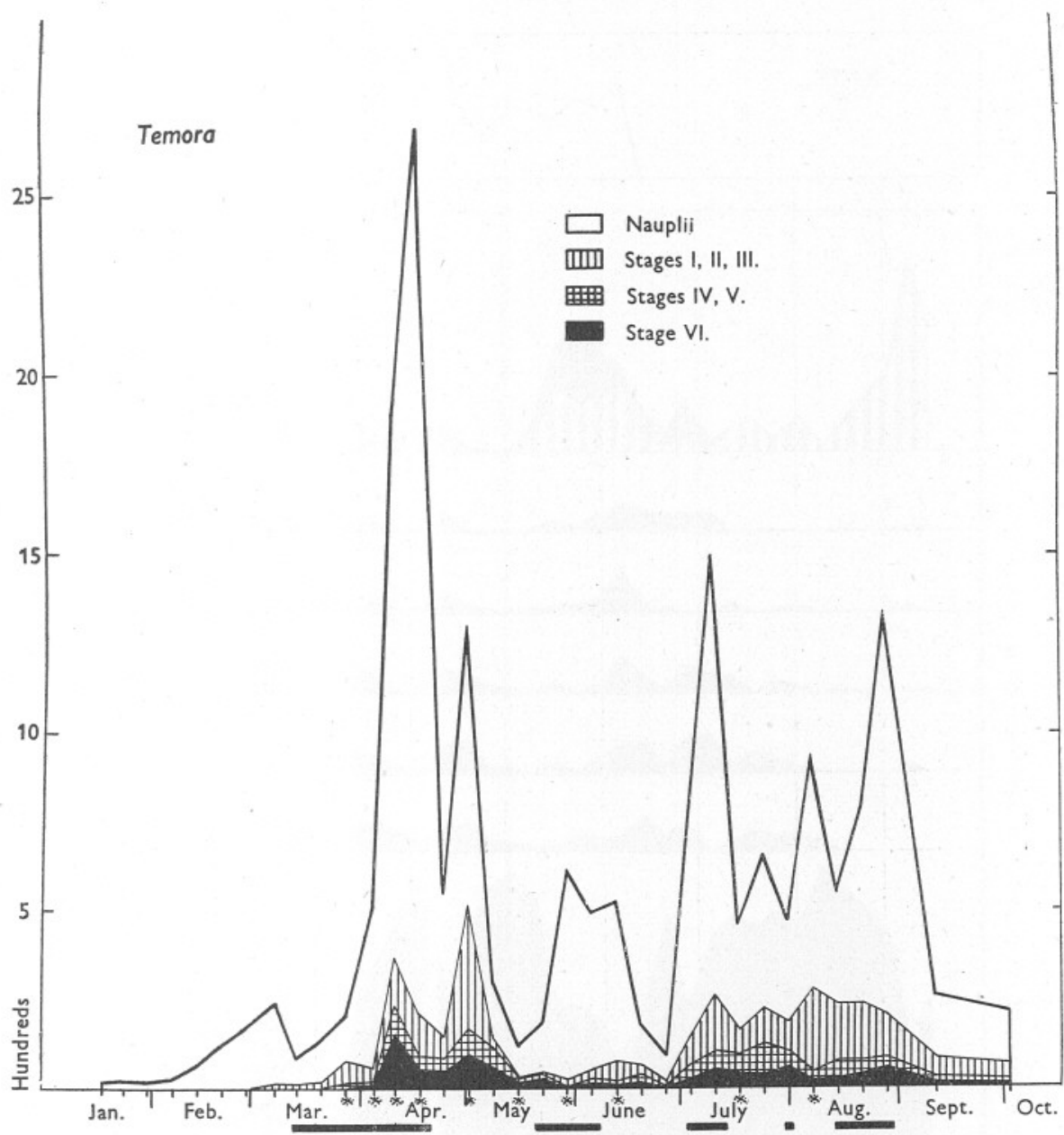

Fig. 1o. Temora longicornis. Total number per haul throughout the year.

only I3 \%. The number of spermatophore-bearing females is shown at the top of Figs. 7 and 9, and it is on the whole highest on the appearance of the first brood and varies irregularly throughout the summer. The peak in Centropages on 26 June means little, for only two females were caught, one with a spermatophore. 


\section{Acartia clausi Giesbrecht}

(Table VIII, Figs. II and I2)

The stock of Acartia in January, unlike the other species examined, consisted almost entirely of adult females and nauplii. In February and March

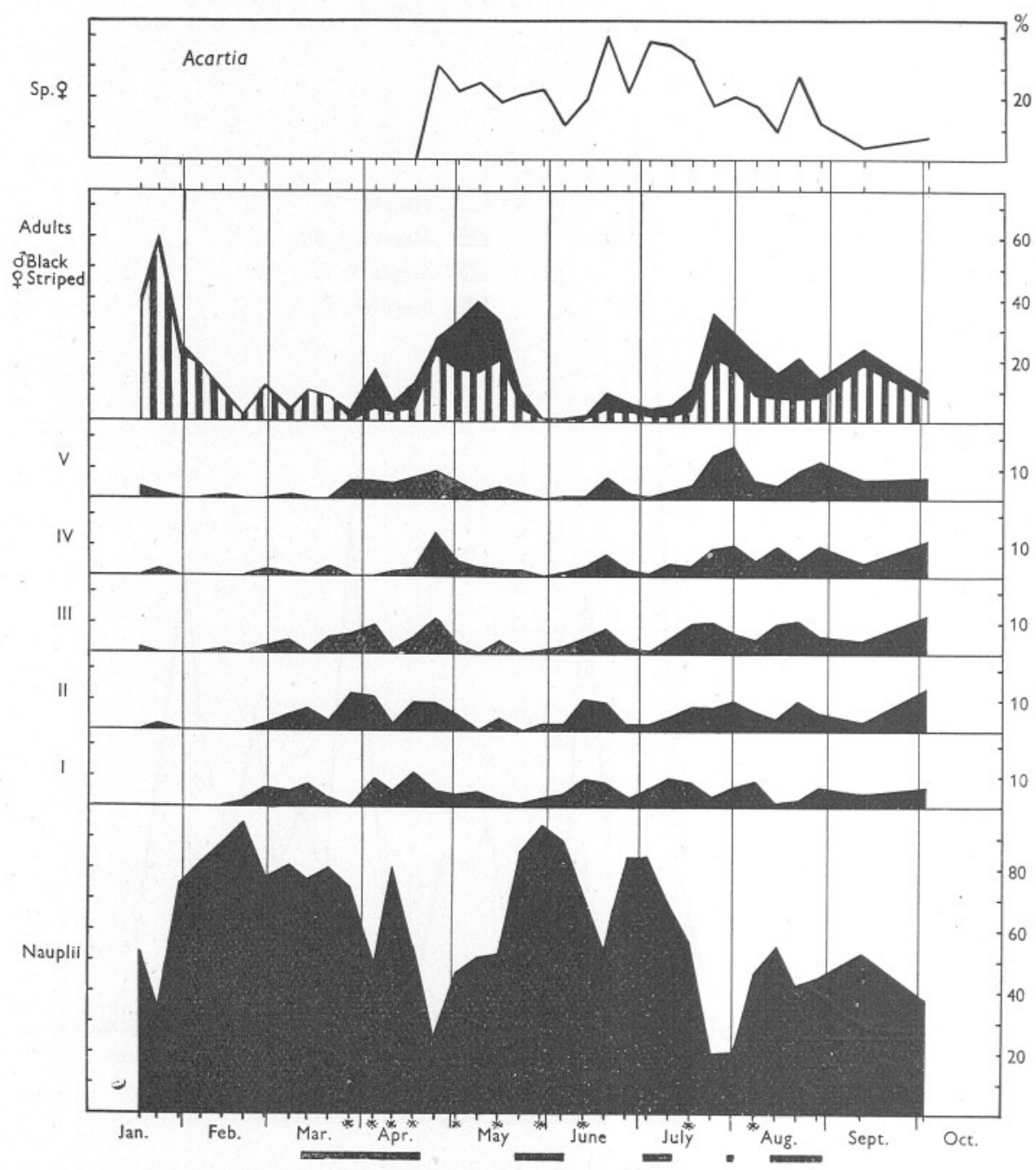

Fig. Ir. Acartia clausi. Diagram showing the percentage of developmental stages during the year. The percentage of adult females with spermatophores is shown at the top.

nauplii predominated, and in the latter half of March (along with the spring diatoms) the first brood grew up. The period of reproduction was rather spread out, or else there were two broods in close succession, of which the second 
came to maturity at the beginning of May. The numbers at this time were, however, very small and hardly show in Fig. I2.

Another peak in nauplius production came with the diatom increase at the end of May, and this brood began to grow up during June. It is difficult to follow it to maturity, however, because of the sudden change (already mentioned) on I9 June in the proportions of nauplii and late copepodites.

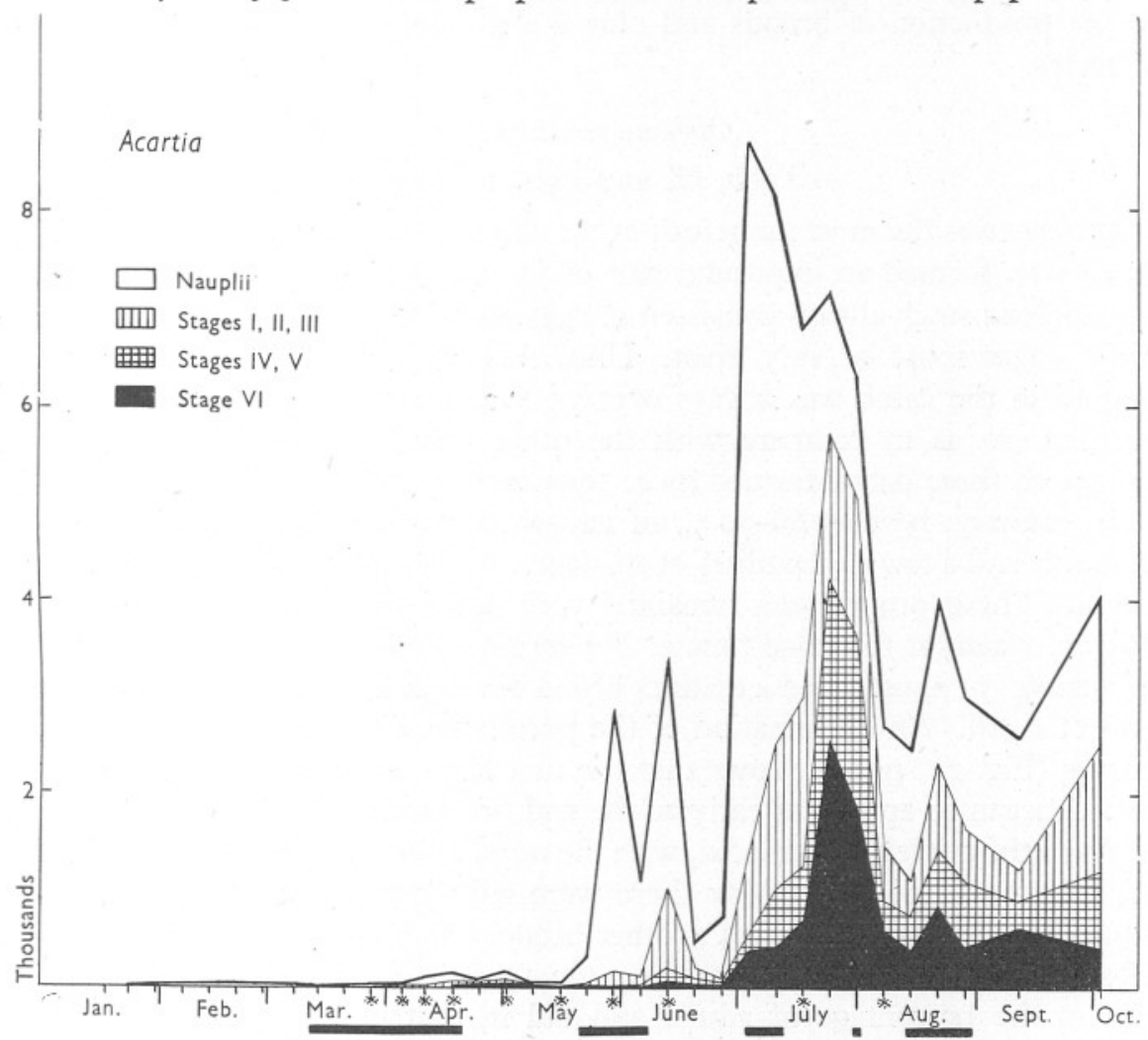

Fig. I2. Acartia clausi. Total number per haul throughout the year.

The peak in nauplius production at the beginning of July coincided with a diatom increase, and a brood, the third or fourth, developed during the month and reached the adult stage at the end of July and beginning of August. After this, breeding seemed to be continuous and the number of copepodites and adults remained high. When observations stopped in October there were less than $40 \%$ of nauplii and the other $60 \%$ was fairly evenly distributed among the different copepodite stages, so that in Acartia, too, it is possible that breeding may go on well into the winter.

The maximum number for the year occurred in July, as nauplii at the beginning of the month and as copepodites and adults (5000 per haul) at the end. 
Taken over the year the sexes were almost equal in number in all stages where they are distinguishable (Table I, p. 57). Although among adults females predominated up to April and after August, during the summer months males often outnumbered females. There were no females carrying spermatophores in January and February, but from the end of April the number was high, especially during June and July, but it seemed to have no relation to the production of broods and only a slight relation to the predominance of males.

\section{Oithona similis Claus}

\section{(Table IX and Figs. I3 and I4)}

Oithona was the most numerous of the small copepods, and so, in spite of its small size, formed an important part of the plankton. A large proportion of the Oithona stock always consisted of eggs and nauplii; the mortality in these early stages must be very great. Until August the percentage of eggs and nauplii in the catch was always over 75 and often over 90. When eggs are omitted (so as to compare with the other copepods studied) the nauplii, except on three dates, formed more than half the catch.

In January, besides $60-70 \%$ of nauplii the stock contained nearly $20 \%$ of adults and a few copepodites of all stages, so that breeding may already have begun. These proportions remained very much the same until the end of March, when (at the same time as the spring diatoms) there was a rise in the percentage of nauplii and a distinct brood developed, reaching maturity at the end of April. An examination of the percentage size-frequency distribution curves (Fig. 29, p. 8I) shows that the first large adult females of the spring brood began to appear as early as the end of March. From then till the end of April the curves are bimodal, with the number at the larger mode increasing until on 24 April and I May there were only large females present. These adults immediately produced another brood which grew up during May, but after this breeding was continuous. On I9 June there was the same abrupt rise in the percentage of adults and fall in that of nauplii as occurred in Temora, Centropages and Acartia. From July onwards the proportion of nauplii was lower than during the earlier part of the year. When observations stopped, adults and copepodites formed $60 \%$ of the stock, and breeding may have continued throughout the winter.

Although Oithona was numerous throughout the year the numbers rose sharply only at the beginning of July, and the total stock (excluding eggs) on 3 July was I8,000 per haul. Numbers fell again to the beginning of August and then rose to the maximum for the year on $2 \mathrm{I}$ and 28 August when there were about 30,000 copepodites and nauplii, with 13,000 and 6000 eggs in successive weeks.

Males were always much scarcer than females, the discrepancy being most marked in early spring (Table I, p. 57). In January and March the males 
numbered only $2 \%$ of the adults, for the whole year $13 \%$. The number of females with spermatophores was about Io \% or less until April, but after this, with the higher proportion of males, it remained consistently high. The

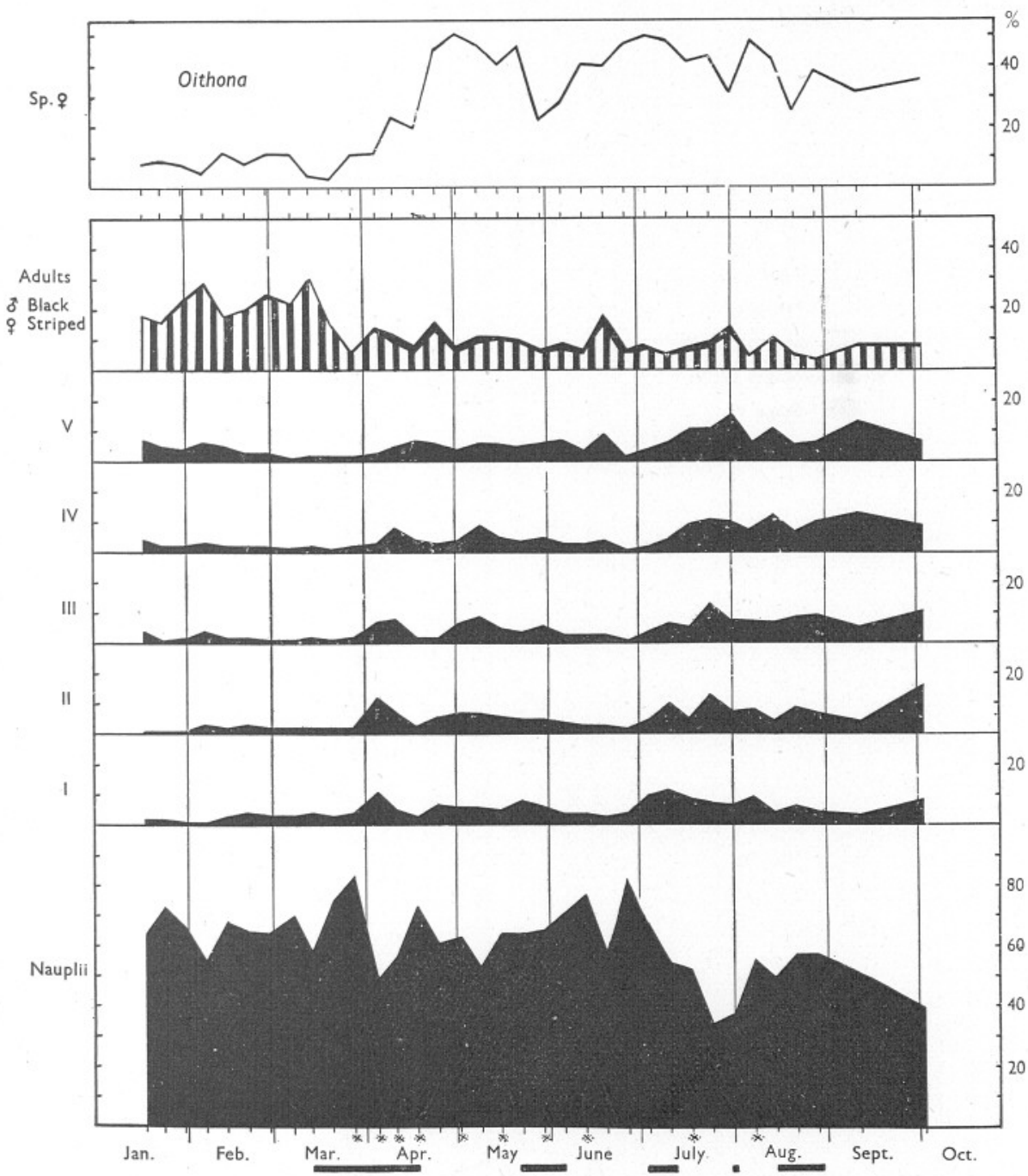

Fig. I3. Oithona similis. Diagram showing the percentage of developmental stages during the year. The percentage of adult females with spermatophores is shown at the top.

figure probably means little, however, for among the females carrying egg-sacs some had spermatophores and some had not (see p. 69).

The eggs are carried by the female in a pair of egg-sacs attached to the genital segment, so it is possible to count the number of eggs per sac and per 


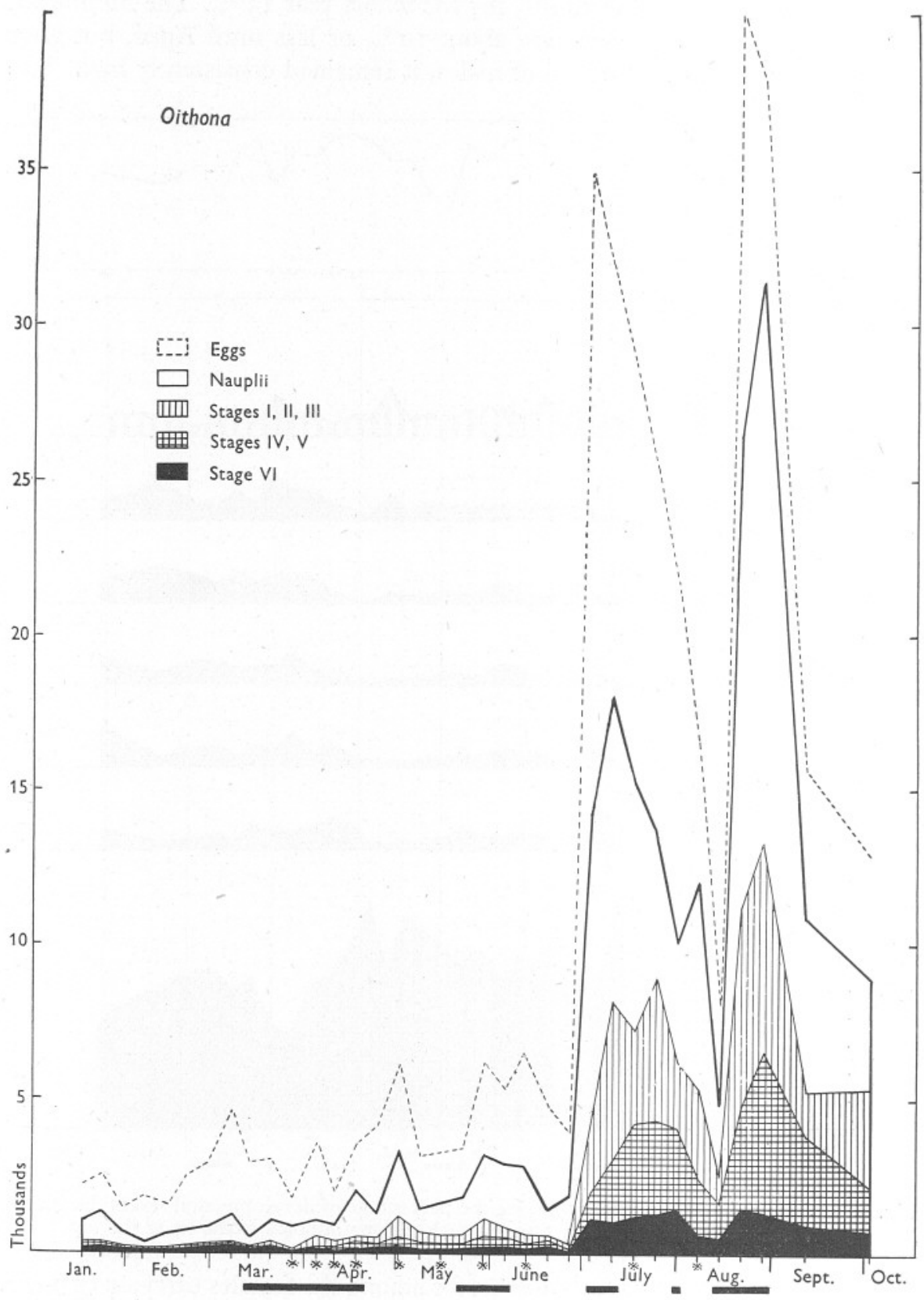

Fig. 14. Oithona similis. Total number per haul throughout the year. 
female, and the latter is shown in Fig.3 (p. 53). As in Pseudocalanus the number increased gradually to a maximum at the end of April, at the end of the spring diatom increase, when females were about their maximum size. There was then a rapid decrease in number until the middle of May, but from then till 5 June, unlike Pseudocalanus, there was a sharp rise to a second maximum. Thereafter numbers decreased gradually till the autumn, although there were two slight checks on the curve on the same dates as those found in Pseudocalanus.

The paired sacs did not always contain the same number of eggs, although they were usually nearly the same. The number per egg-sac varied from four to thirty-four, and almost the whole range might be covered in one catch. Over Ioo egg-sacs were usually counted.

The curves indicate that the relation between number of eggs and size of female is less close than in Pseudocalanus, although the correlation coefficient is still highly significant $(0.75,35$ pairs of observations). An examination of Figs. 3 and 28 shows that whereas egg numbers rose to a well-marked peak on 5 June the size of females showed only a slight rise at that time. Diatoms were abundant while the egg numbers were rising, and were scarce after 5 June, so that it is probable that the food supply has an effect on egg production. Diatoms were abundant also on the dates in July and August when the downward trend of egg number is checked, but the differences in egg number are not significant. Otten (I9I3) counted the number of eggs per sac and found that this varied throughout the year, being, like the nauplii, highest in April and October and lowest in August.

In considering the reproduction of the copepods as a whole, we can see that there are two types of breeding. In one the broods are distinctly separated by periods when eggs and nauplii are scarce. To this type belong Calanus and Microcalanus. In all the other copepods examined the broods were less distinctly separated and in the second half of the year were indistinguishable. In the second type there seems to be a shorter time between the appearance of adult females and the production of eggs and nauplii. In Calanus (Fish, I936a; Marshall et al., I934) the maturing of the eggs is supposed to take about 3-4. weeks, and the same seems to be true of Microcalanus. In the other copepods a peak in nauplius numbers followed more closely (in two or three weeks) upon the appearance of adults, and two broods might appear in quick succession. In the late summer when breeding was continuous, no gap could be distinguished (see, however, Fish, 1936b, on Pseudocalanus).

In Calanus the time occupied in development from egg to adult was estimated, partly from the data from the Loch Striven hauls and partly from laboratory experiments, at about a month. There are no laboratory data for the small copepods, and since visits to the loch were made only weekly, estimates must be uncertain, but the time seems to be little shorter than in 
Calanas. In most species the time from a peak in nauplius production to a peak of adults is $3-4$ weeks. The great differences between spring and summer mentioned by Fish (1936c) do not occur here.

In all species the spring diatom increase seems to have had an important effect on reproduction. Although Microcalanus and possibly Oithona were breeding before it, yet during or at the end of the diatom-rich period (which in 1933 was long-drawn out-I3 March to I7 April), every species showed an increase, in most of nauplii, and in all a successive development of early and late copepodites and adults. The date varied from one species to another between the middle of March and the middle of April. In Pseudocalanus and Acartia the actual numbers of the first brood were very small; in Microcalanus, Centropages and Temora they were considerable, especially when compared with the numbers occurring later in the year. In all species nauplii form a large proportion of almost every catch, and the greatest mortality must take place at this early stage. Fish $(1936 a, b)$ suggests that another dangerous period in the life of a copepod is during the maturing of the eggs, and that in Calanus the mortality is actually greatest at that stage, and is important also in Pseudocalanus.

The maximum number of all species of copepod except Temora, and sometimes Calanus (Nicholls, 1933), came during the summer, in July or August, but the date varied from species to species. This was true for the maximum numbers both of nauplii, and of copepodites and adults, which in Microcalanus and Oithona occurred on the same date. Besides this summer maximum there was usually a secondary maximum earlier in the year, in April or May, but this was smaller and more variable. In Acartia and Oithona it was small, in Temora it was more important than the summer maximum.

The proportion of the sexes varied among the different species, and it varies also from place to place. Otten (1913) gives figures for seven copepods (Table I, p. 57), mostly the same species as those in Loch Striven, but in his samples males were much scarcer. In both places, however, Oithona had the smallest, and Centropages and Temora the highest, proportion.

In Loch Striven (Table I) the percentage of males in Calanus, Pseudocalanus, Acartia and Oithona was lowest from January to March. In Calanus and Pseudocalanus it was highest from April to June, but in Acartia and Oithona the proportion did not vary much from April onwards. Centropages and Temora were too scarce before April for the number of males to be reliable, and after April the proportion remained fairly constant. In Microcalanis, on the other hand, their percentage was highest in April and was very low after June.

If, as seems most probable, these very varying proportions indicate the length of life of the adult, then in some species the female is the longer lived, in others the male. The length of life also varies at different times of the year, and this we already know to be true of some of the earlier stages such as Stages IV and V of the autumn stock of Calanus, Pseudocalanus and Paracalanus. 
In Calanus (Marshall et al., I934) the percentage of adult females carrying spermatophores was highest before the production of each brood of eggs, and it was observed that the spermatophore was usually lost before the eggs were ripe for spawning. No such relation was made out in the small copepods. In one species (Oithona similis) the spermatophore was often retained even after the eggs had been spawned, and this may be so in other species also. It is curious, too, that the very varying proportion of males seems to have little influence on the number of females carrying spermatophores.

\section{VerTiCAL Distribution}

From 27 March to 2I August one of the five hauls was taken in two parts, from the bottom $(60-70 \mathrm{~m}$.) to Io m., and from Io m. to the surface. It must, however, be remembered (see p. 46) that there may have been a considerable and variable loss from the bottom haul which means that the proportion of copepods below Io $\mathrm{m}$. may be greater than appears from the figures. It is felt that despite this disadvantage the results obtained are substantially true.

In Fig. I5 is shown for all stages of each species the percentage above and below Io $\mathrm{m}$. No allowance has been made for the much greater depth of water sampled below Io $\mathrm{m}$. It is felt that the copepods are very unlikely to be evenly distributed throughout the column, and there are in fact indications that they may have been confined to the top 20 or $30 \mathrm{~m}$. A series of samples taken at Io m. intervals from top to bottom would give a truer picture of their distribution.

It will be seen that from the end of March till the middle of June the great majority of all stages of all species except Microcalanus was above Io $\mathrm{m}$. There was then a rapid descent, and in July most stages of all species were wholly or largely below Io m. In August there was a gradual rise again in most species, more marked in the younger stages, but when observations stopped on 2 I August the distribution had not yet returned to the state shown at the end of March.

Although this gives a general picture of the copepod distribution, there was considerable variation in detail between the different species and the different stages of the same species. Microcalanus was unlike any of the others, since during almost the whole year all stages remained consistently below Io $\mathrm{m}$. On 22 and 29 May the proportion of Stages II and III above IO m. increased, but the numbers then present were too small to be significant, and on the last two dates in August Stages I and II were absent altogether. The rise of the nauplii in August, however, was based on considerable numbers and seems to be real. On the first two dates, $27 \mathrm{March}$ and 4 April, a considerable proportion of all stages except males and nauplii was found above ro m., and this may mean that there is a period during the winter when Microcalanus, like the other copepods, lives mostly near the surface. Further observations are needed to 


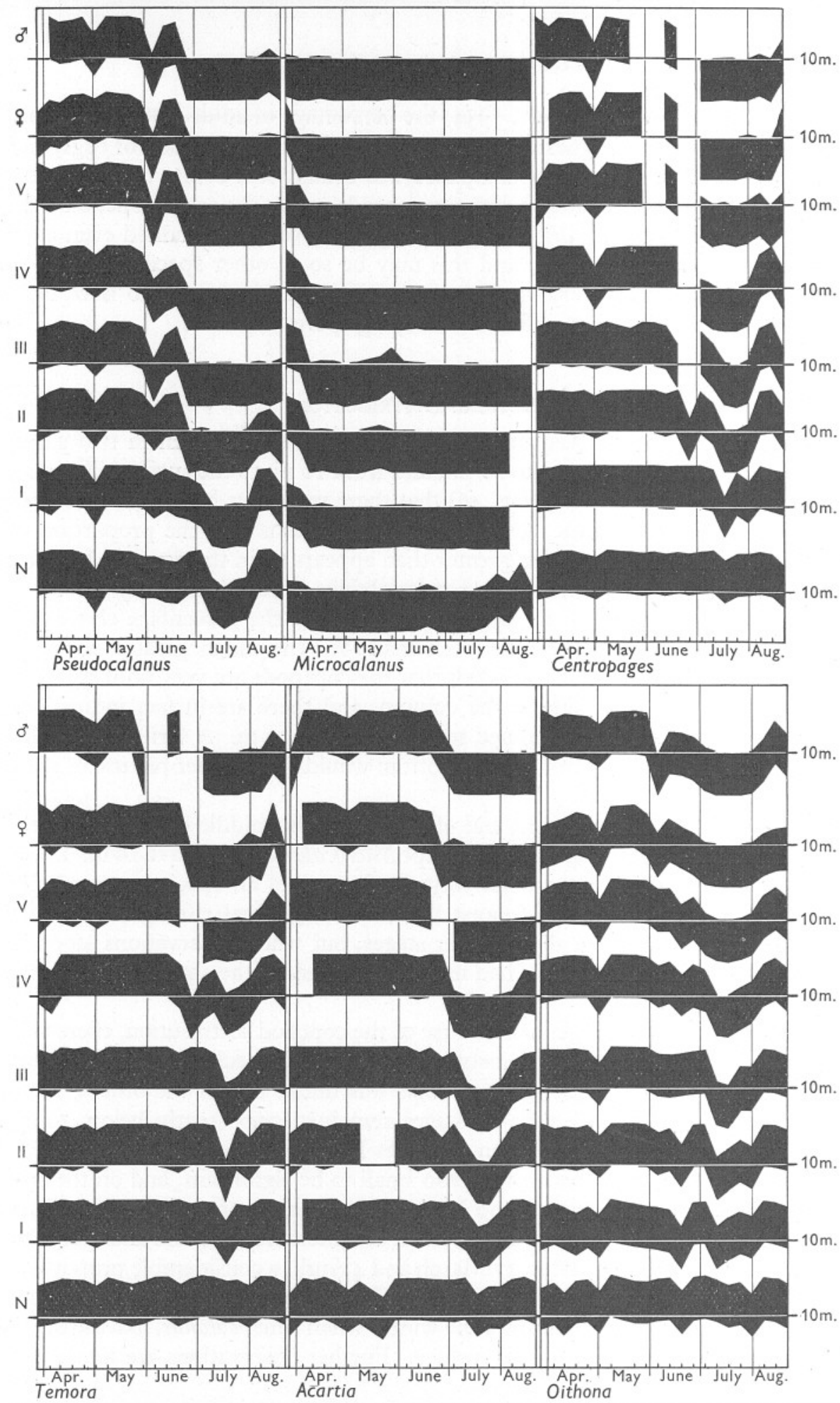

Fig. 15. Diagram showing the percentage of copepods above and below Io $\mathrm{m}$. from $27 \mathrm{March}$ to 2I August. The nauplii and copepodite Stages I-VI are shown separately for each species. 
decide the point, but it may be noted that off East Greenland (Ussing, I938) Microcalanus, like most other species, is found near the surface in winter and in deep water in summer.

In Calanus (Marshall et al. 1934) the adults and Stage V went below ro m. in the beginning of June, and the earlier copepodites not till the beginning of July. In the adults and Stage V of this species it was therefore those of the first brood only which were found above ro $\mathrm{m}$. All stages stayed mainly below Io m. until observations ended on 2I August.

In Pseudocalanus and Acartia the return to the surface in August did not take place in the older stages. In Pseudocalanus all stages from adults down to Stage III, and in Acartia adults and Stage V remained below Io $\mathrm{m}$. until observations stopped. In the younger stages the descent in July lasted for a shorter time, and there was a gradual rise again during August. The nauplii of Acartia, indeed, remained largely above $10 \mathrm{~m}$. all the time.

Centropages and Temora resembled each other closely, and although the course of events was the same the descent in July was in general less marked than in the other copepods. Numbers in June were too low to give a reliable estimate for the adults and older copepodites, but all were below $\mathrm{Io} \mathrm{m}$. by the beginning of July. The younger stages went down later and rose earlier and the nauplii showed little change at all. A considerable proportion even of adults had risen to the surface again in August.

Oithona showed the same changes, but in even less degree. There were few dates on which copepodite Stages I and II were mostly below Io m., and in August the adults and older copepodites were again mainly above $\mathrm{Io}$ m.

All copepods but Microcalanus, then, showed the same series of changes, but the younger the stage the less marked the descent into deeper water and the more rapid the subsequent rise. Among nauplii only Pseudocalanus showed a clear migration downwards, and in Temora and Oithona the descent was little marked even in Stages I and II. The time of descent did not correspond to the presence of any particular brood except in Calanus.

Since this summer migration occurs in so many species of copepod there is probably some environmental factor causing it. Fish (1936b) says that in the Gulf of Maine Pseudocalanus disappears from the inshore waters in June and July when the temperature rises above 15 or $20^{\circ} \mathrm{C}$., and is found in colder bottom water during the summer. In Loch Striven the temperature never rose much above $15^{\circ} \mathrm{C}$. and that not till the end of July, but it is possible that the downward migration may have been caused by increasing warmth. Ussing (1938) attributes the migration to light, and this, too, may have been a factor in Loch Striven.

Apart from this seasonal retreat into deeper water there were several days on which there was a sudden increase of the copepods below $10 \mathrm{~m}$. Such dates were I May, 5 June and possibly 2I August. The sudden dip is not seen in the 
curves for all species or all stages, but it is apparent in many, most clearly in Pseudocalanus and Oithona, so that these descents also had probably some common environmental cause. They cannot be accounted for by the weather on these particular days, for although I May was bright with high cloud, 5 June and 2I August were overcast and rainy.

It is possible that water movement caused by wind was responsible. Such movements may go on for several days after the wind which caused them has died away. The abrupt temperature fluctuations shown in May and June (Marshall et al., 1934, Fig. 5, p. 804) at the surface, and occasionally even at $30 \mathrm{~m}$. (the only depths where temperatures were measured), support this suggestion, and the fact that such migrations are shown in almost all stages of development, even when the temperature change does not go as deep as $30 \mathrm{~m}$., suggests that the population was living above this depth. In the marked disturbance of distribution shown on 5 June the nauplii and young copepodites were less affected than the old, perhaps because they were living nearer the surface.

\section{Size}

The size of the six species of copepod from copepodite Stage III upwards was measured every week when available. When possible samples of about Ioo were used, but the number was often lower, especially in Centropages and Temora. The measurement used was that of the cephalothorax except in Oithona, where it was taken from the tip of the cephalothorax to the end of the first abdominal segment. This was to make the measurement comparable with that of the other copepods, since in Cyclopidae the 'joint' comes between the first and second abdominal segments. The results are shown in Tables X-XVII and Figs. I6-29. Figs. I6, I8, 20, 22, 24, 26 and 28 show the median length throughout the year, Figs. I7, I9, 21, 23, 25, 27 and 29 the percentage sizefrequency distribution. For economy of space the latter is not shown for every week but only for a selected number of dates.

All measurements were made with an ocular micrometer whose divisions equalled $\mathrm{I} 7 \cdot 4 \mu$. Those between two divisions were taken at the lower figure. In Tables X-XVII the measurements have, for economy in space, been grouped either in twos (for the smaller copepods Microcalanus, Paracalanus and Oithona) or in threes (for Pseudocalanus, Centropages, Temora and Acartia), so that each column corresponds to a size difference of 35 or of $52 \mu$. Figs. I6-29 have, however, been prepared from the extended series of measurements.

Sex differences. The size relationship between the sexes differs considerably in the different species of copepod. Normally the female is the larger, both when adult and in those copepodite stages where the sexes can be distinguished, although in Stage IV the difference is often negligible. This is so in Calanus and Oithona (where the sex can be distinguished only in the adult), and also in Centropages, Temora and Acartia. 


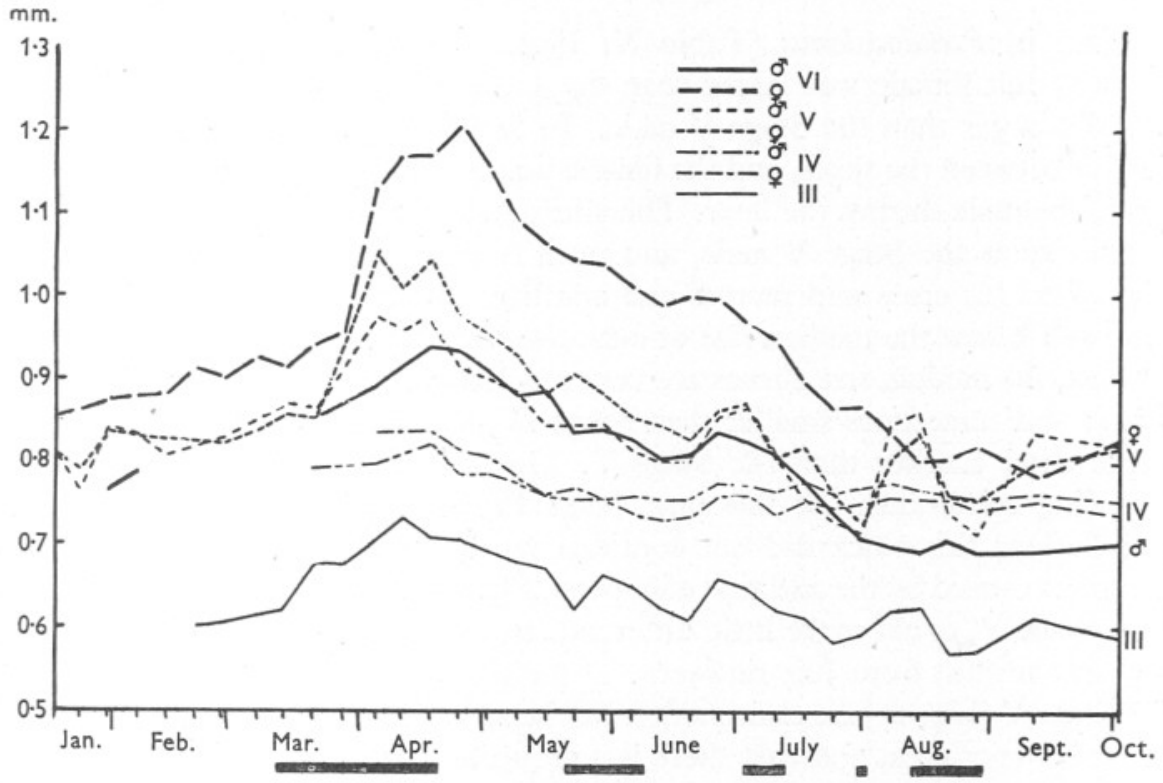

Fig. I6. Pseudocalanus minutus. Median size of copepodite Stages III-VI throughout the year

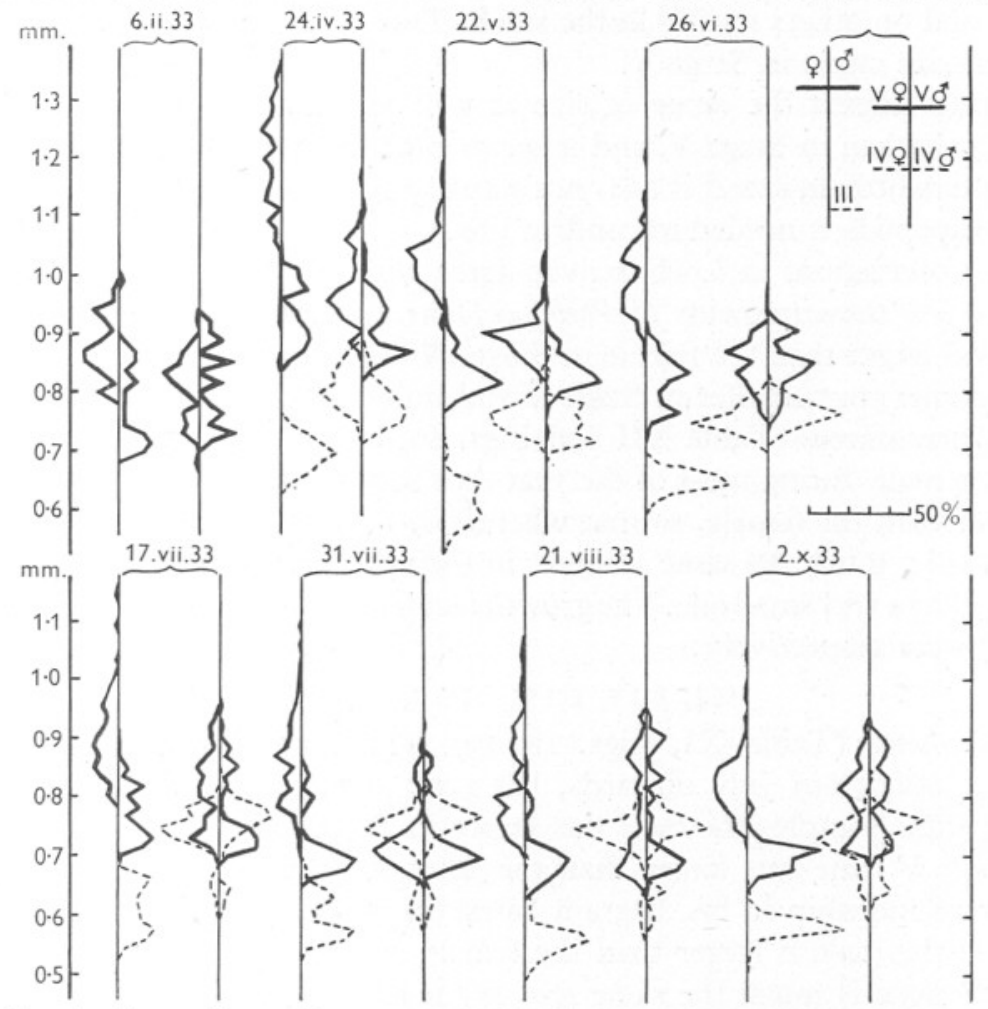

Fig. I7. Pseudocalanus minutus. Percentage size distribution of Stages III-VI on selected dates. 
Sizes in Pseudocalanus (Table X, Figs. I6, I7) were normal in so far as the adult female was larger than the adult male, and the Stage V female usually larger than the Stage V male. In Stage IV there was little difference in size between the sexes, and the female was larger during the early part of the year, the male during the later. The adult male was, however, only about the same size as the Stage V male, and until August the two curves for median size (Fig. I6) cross and recross one another. After August it is smaller still and well below the median size of even the Stage IV. From August onwards, indeed, the median size curves are very much mixed up; Stage V is sometimes larger and sometimes smaller than Stage IV, and even the adult female is on some dates smaller than the Stage V. This can be partly explained by the breeding conditions. At this time Stage IV made up 40-60\% of the total population; this stock did not continue its development, and any small alterations caused by the addition of copepods from Stage III, or loss by moulting into Stage V, could make little difference to the median size, which remained almost constant from July onwards. If the size-frequency distribution curves for Stage V (Fig. I7) are examined, it can be seen that in August the total range in size is very great and that there is a group of large and of small Stage $V$ in both male and female. On some dates most of the Stage V are in the large group and on others mostly in the small. This accounts for the very irregular median-size curve in Stage V.

During August the range of size as well as the mode was smaller in the adult male than in Stage V, and it seems probable that in the final moult the male alters little in size if it does not actually decrease. Experimental work on living copepods is needed to confirm this.

The observations in Loch Striven agree with those of Kraefft (I9I0), who made a few measurements of Pseudocalanus in Kiel Bay and found that the male was larger than the female in Stage IV (like the Loch Striven samples in late summer) but smaller in Stage $\mathrm{V}$ and much smaller in the adult.

In Microcalanus (Table XII and Figs. 20, 2I) the adult female was larger than the male during most of the year, but in both Stages V and IV the male is larger than the female, so that whereas in its three final moults the female increases by much the same amount, in the male there are two large increases followed by a very small one. The growth factors (ratio of the size before and after moult) were respectively:

$$
\mathrm{I} \cdot \mathrm{I} 4, \mathrm{I} \cdot \mathrm{I} 7, \mathrm{I} \cdot \mathrm{I} 5 ; \mathrm{I} \cdot 22, \mathrm{I} \cdot 20, \mathrm{I} \cdot 04 \text {. }
$$

Paracalanus (Table XI, Figs. I8, I9), which was numerous enough to measure only from July onwards, has gone even further from the normal, and in these samples the male was larger in Stages IV, V and VI, and even the Stage V male was larger than the adult female. Kraefft (I9I0) shows a similar relationship in his diagram based on measurements in February and August; the male is larger than the female in Stages IV, V and VI, but the Stage V male is much the same size as the adult female. 
Seasonal change. Apart from these minor sex differences the size of all the copepods showed a seasonal change. Comparatively small in winter, the size of all stages, especially the adults, underwent a great and rapid increase in spring to a maximum sometime in April, and there was then a gradual decline until August. After this there was in most species little further change, and the sizes were much the same as those found in January.

Since Paracalanus copepodites (Table XI and Figs. I8, I9) did not appear in numbers till July, it cannot be known whether it conformed to this normal

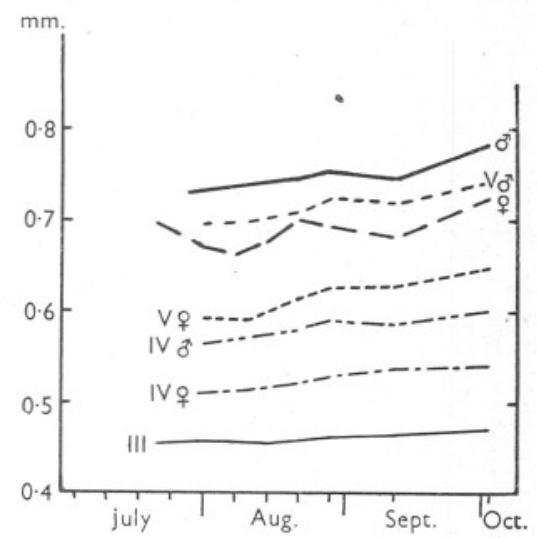

Fig. I8.

Fig. 18. Paracalanus parvus. Median size of copepodite Stages III-VI from July to October. Lines as in Fig. I6.

Fig. 19. Paracalanus parvus. Percentage size distribution of Stages III-VI on selected dates.
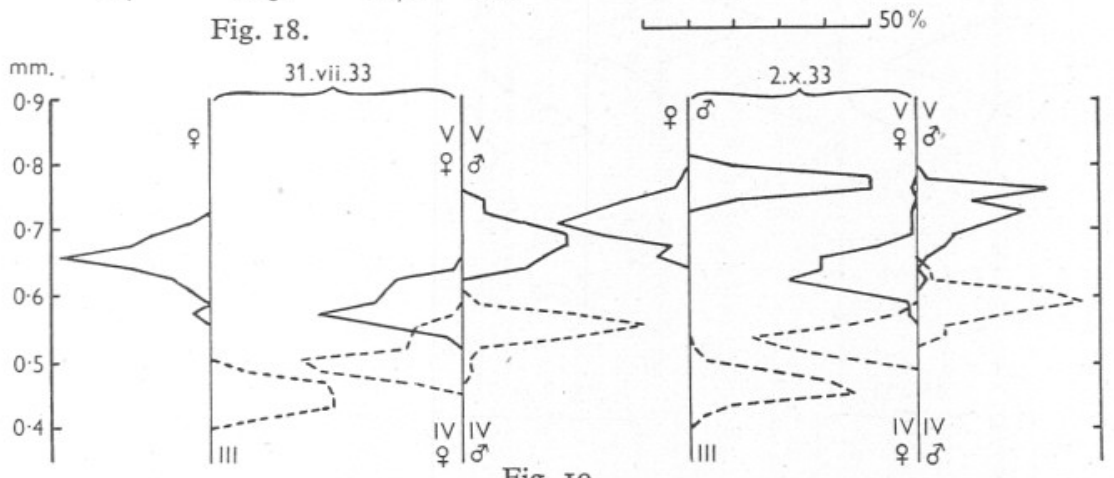

Fig. I9.

type early in the year. From July to October the curves for median size are very regular with a slight tendency to rise. The curves for Microcalanus are also very regular and show only minor variations. In all copepodite stages they rise gently to a maximum, which lasts most of April, and then decline gently during the rest of the year.

In Pseudocalanus (Table $\mathrm{X}$ and Figs. I6, I7) the increase in size in spring was much more abrupt, and there is a well-marked maximum occurring on Io April in Stage III and on 24 April in females. After April there was a more gradual decrease till the autumn, with only minor, and probably not significant, fluctuations. One of the most striking features was the wide range in 


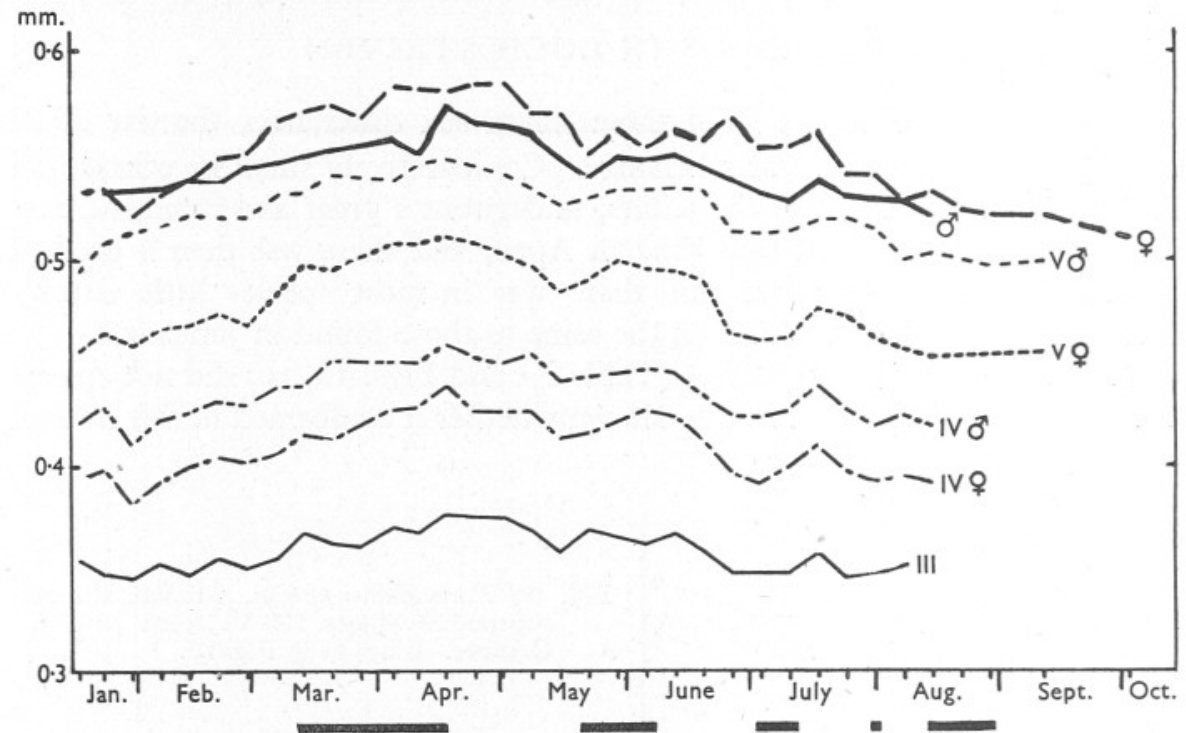

Fig. 20. Microcalanus pygmaeus. Median sizes of copepodite Stages III-VI throughout the year. Lines as in Fig. 16.

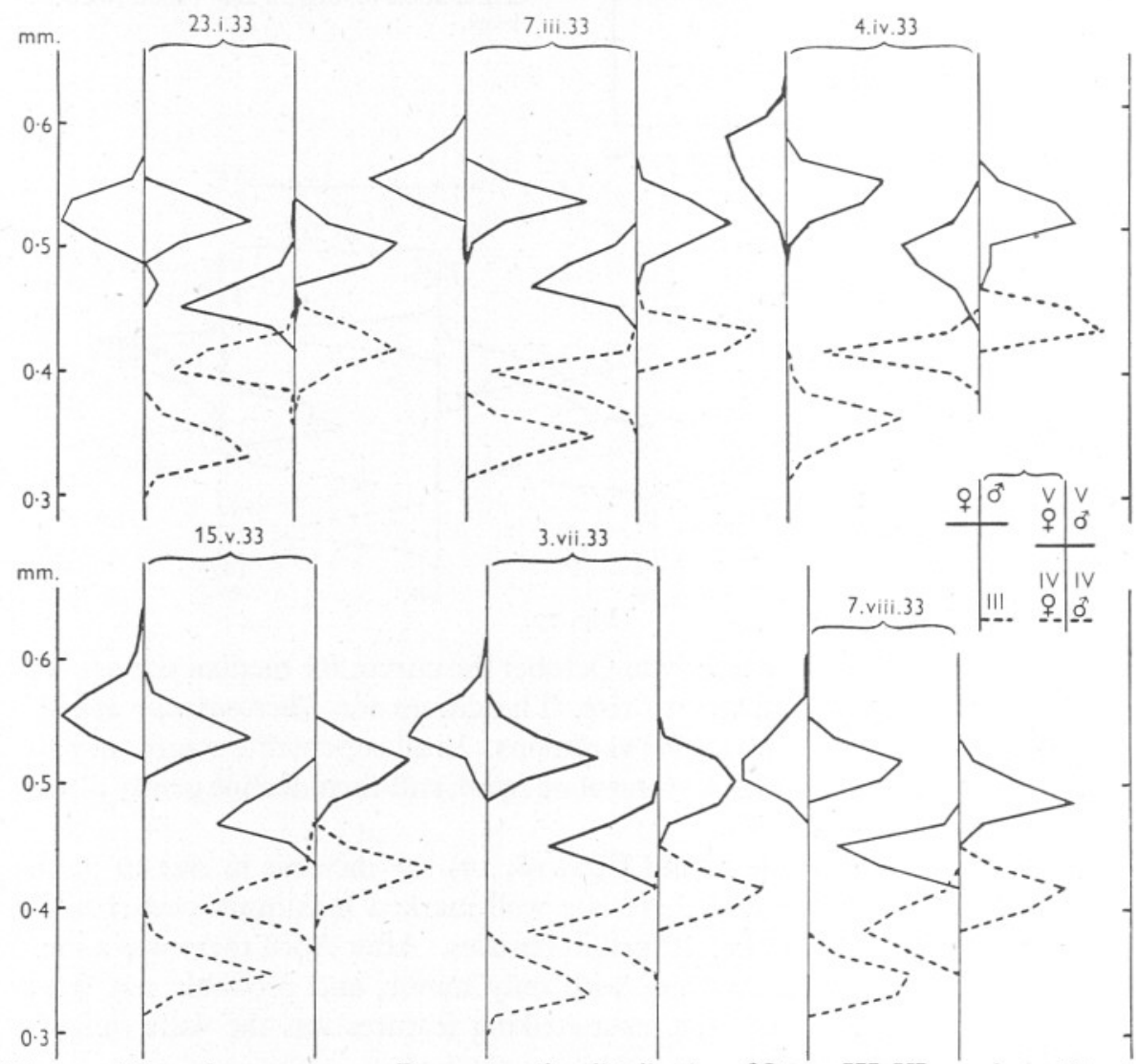

Fig. 2I. Microcalanus pygmaeus. Percentage size distribution of Stages III-VI on selected dates. 
size, so that each stage overlapped the next, sometimes to a considerable extent. Except in Stage III the curves of Fig. I7 are rarely unimodal, and for the older stages are multimodal or very irregular. The two modes seen in Stage III curves do not correspond to the differences in size between male and female Stage IV. Störmer (1929) refers to the great range in size of Pseudocalanus, and the samples of Adler \& Jespersen (I920) show a maximum size range very much the same as that of the females in Loch Striven.

In Calanus with the appearance of a new brood, the size-distribution curves usually became more compact and unimodal as if a large number of similar individuals had moulted together; the median size often showed a rise also (Marshall et al., I934). In Pseudocalanus, however, with its more continuous breeding, this was not obvious. Stage III showed a clearly unimodal curve on its first appearance with the first brood at the end of February, and again at the end of April, May, June and August, perhaps corresponding to broods, but the later stages did not do so regularly. From July onwards, as might be expected from the building up of a large stock which did not develop beyond Stage IV, the curves for Stage IV became more uniform, showing one distinct mode (a little smaller in the female than in the male), with occasionally a smaller size group, perhaps of later-moulting animals.

In Centropages and Temora (Tables XIII, XIV and Figs. 22-25) there were not enough copepods to measure in the early part of the year, but there was a very well-marked size maximum in the later stages of both species on 24 April. The subsequent decline to a minimum in August was interrupted in both species by a smaller increase in size on I9 June, marked only in adults in Temora, but also in Stage V in Centropages. Temora females, although few in number, also showed a decided increase on 15 May, which was the approximate date of appearance of the adults of the second brood. On I9 June, however, there is nothing obvious in either species to account for an increase in size. The numbers of all stages measured (except males) were small, and the change was perhaps not significant. The size of all stages reached a minimum in the end of July or beginning of August and thereafter began to rise again gradually. After II September there were too few to measure. An autumn size-maximum has been described for Temora by Adler \& Jespersen (I920). In both Centropages and Temora the range in size of the different stages, distinct during the early part of the year, came to overlap more and more in late summer (Figs. 23, 25).

Apart from a few females in January and February, Acartia (Table XV and Figs. 26, 27) was too scarce to measure until 24 April or later, but it seems fair to assume that during March and April the size was gradually increasing and that it reached its maximum about 24 April, a date which marked the first appearance of the spring brood. There was a steady decline from then till the beginning of August, after which the size remained pretty constant or rose a little. Stages V and III were present only in very small numbers at the 


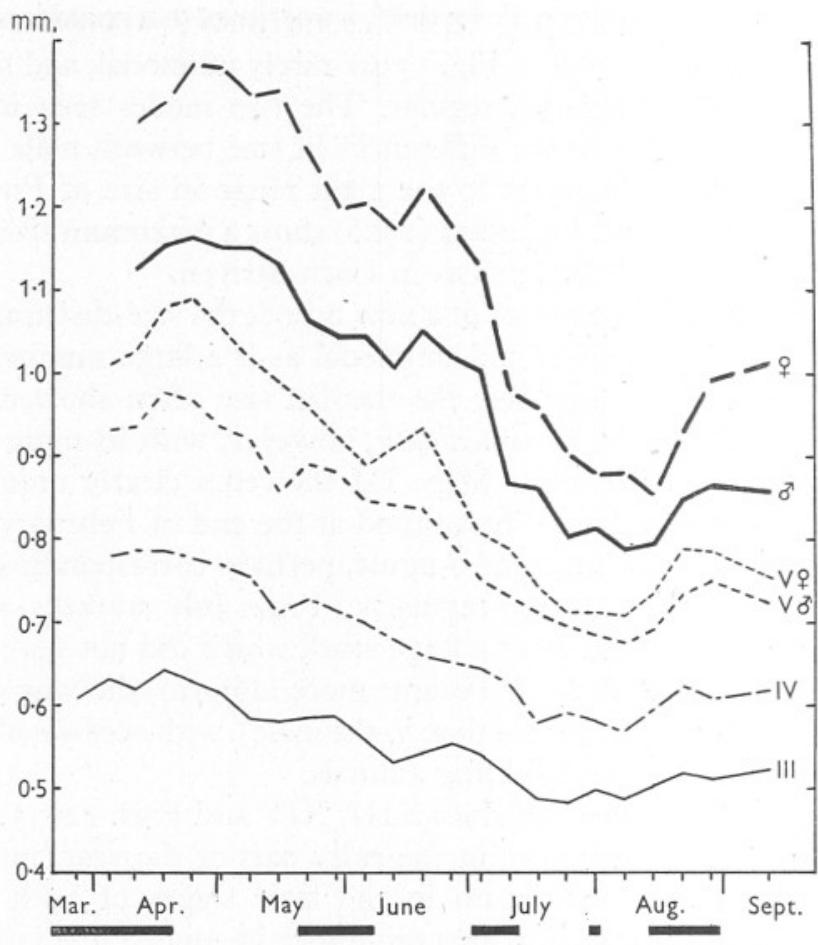

Fig. 22. Centropages hamatus. Median size of copepodite Stages III-VI throughout the year. Lines as in Fig. I6.
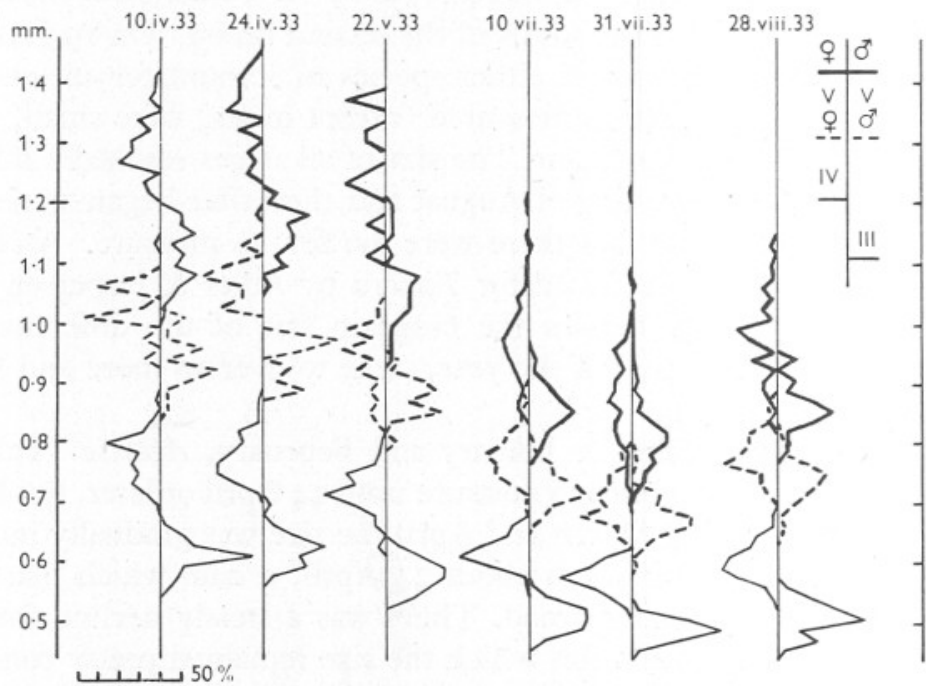

Fig. 23. Centropages hamatus. Percentage size distribution of Stages III-VI on selected dates. 
end of April, and their maximum size is therefore unknown. Acartia differs very much from the other copepods in its size-frequency distribution curves (Fig. 27), for these are almost always clearly unimodal, and the range of size

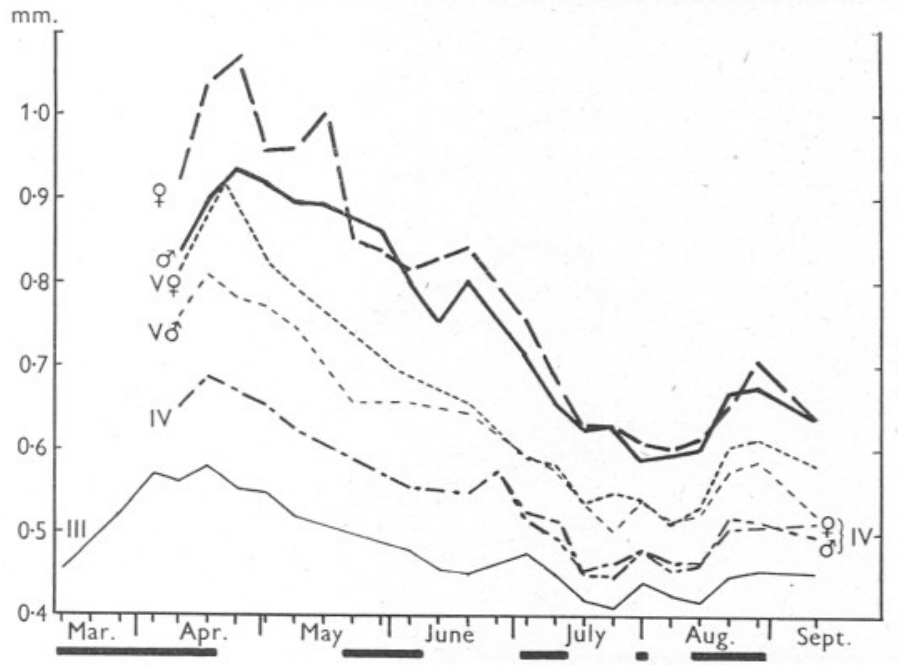

Fig. 24. Temora longicornis. Median size of copepodite Stages III-VI throughout the year. Lines as in Fig. I6.

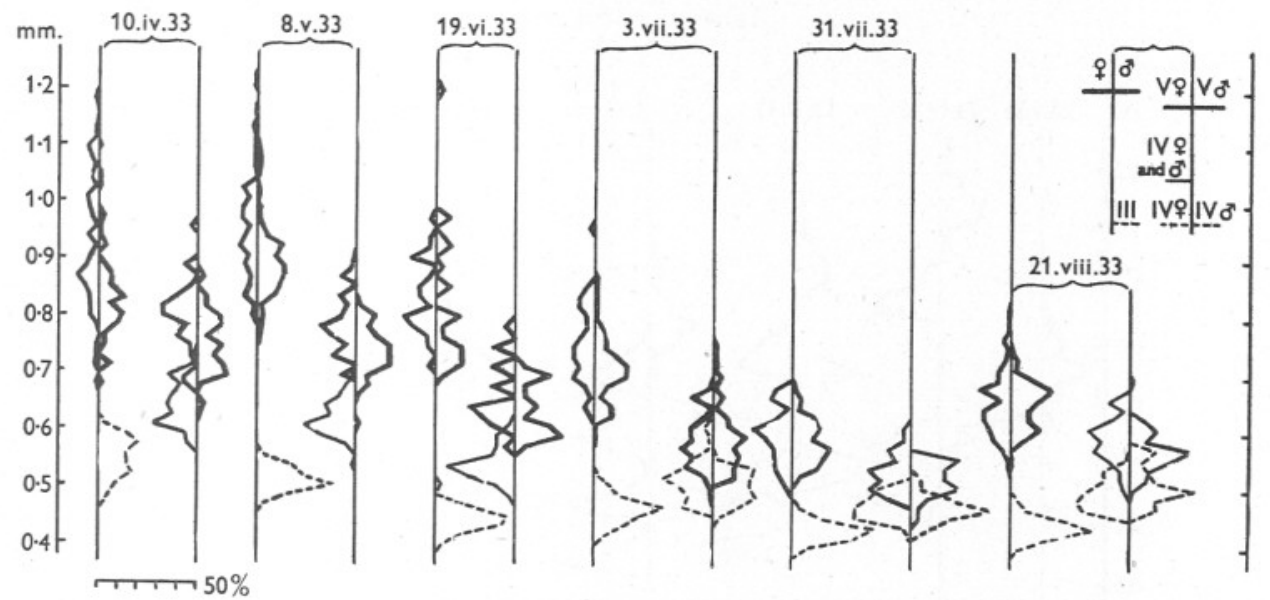

Fig. 25. Temora longicornis. Percentage size distribution of Stages III-VI on selected dates.

of one stage, apart from a few exceptional individuals, scarcely overlaps that of the next.

Oithona (Table XVI and Figs. 28, 29) varied less in size than the other copepods, although there was a gentle rise till the end of April and a subsequent decline. It resembles Microcalanus in its lack of a well-marked maximum in 
spring. There was a slight rise again from 29 May to I9 June which coincided with a diatom increase and also with an increase in the number of eggs produced. After this the size decreased gradually, and by the beginning of August had reached that found in January, where it remained. From January

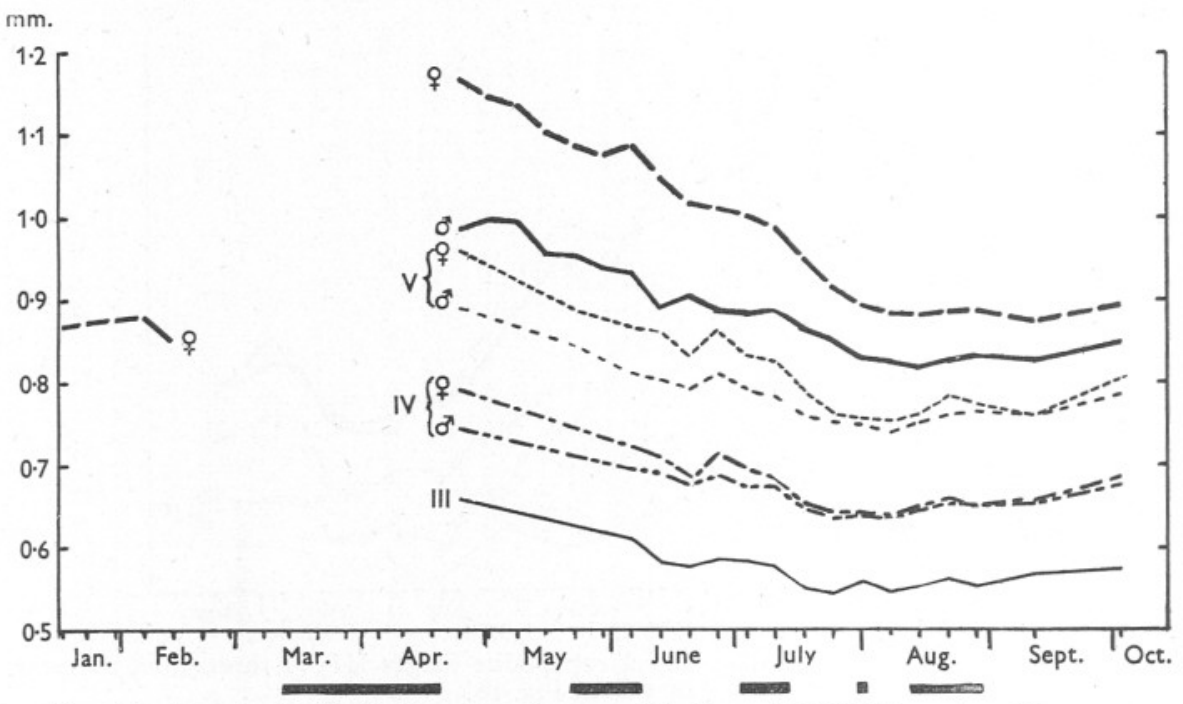

Fig. 26. Acartia clausi. Median size of copepodite Stages III-VI throughout the year. Lines as in Fig. I6.

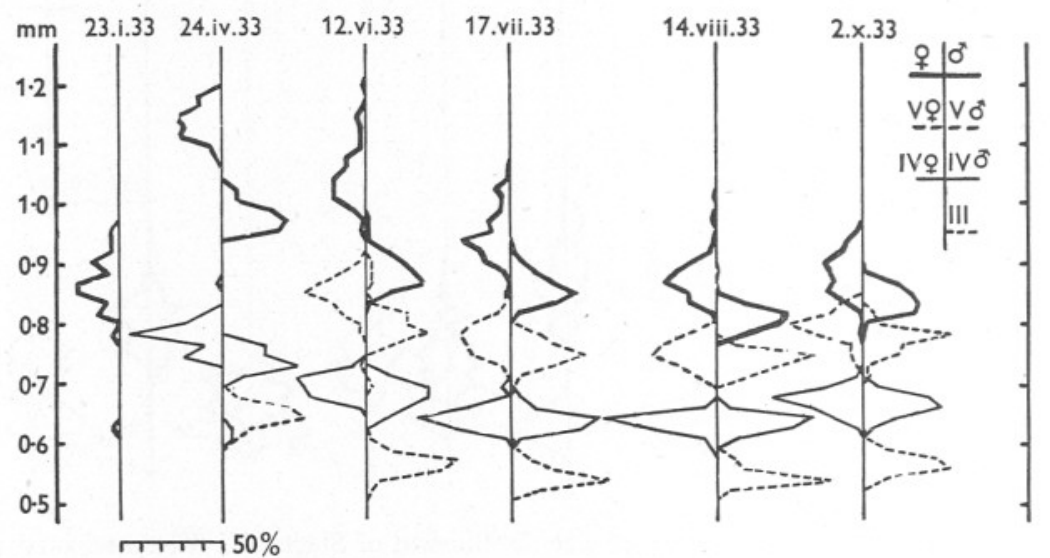

Fig. 27. Acartia clausi. Percentage size distribution of Stages III-VI on selected dates.

to mid-April the size range of Stage $\mathrm{V}$ overlapped almost completely those for both males and females (Fig. 29). For several weeks the median size of males was larger than that of females (Fig. 28) and for 2 weeks Stage V was larger also. If Fig. 29 is examined, however, it will be seen that this is because the 


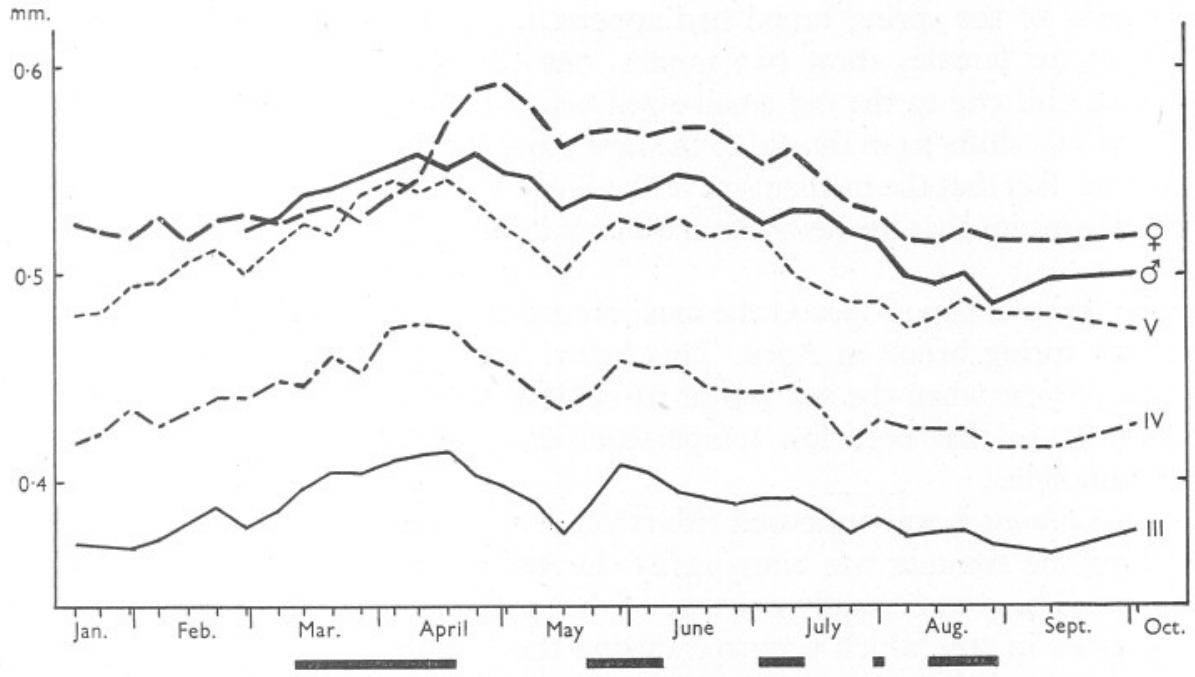

Fig. 28. Oithona similis. Median size of copepodite Stages III-VI throughout the year. Lines as in Fig. I6.
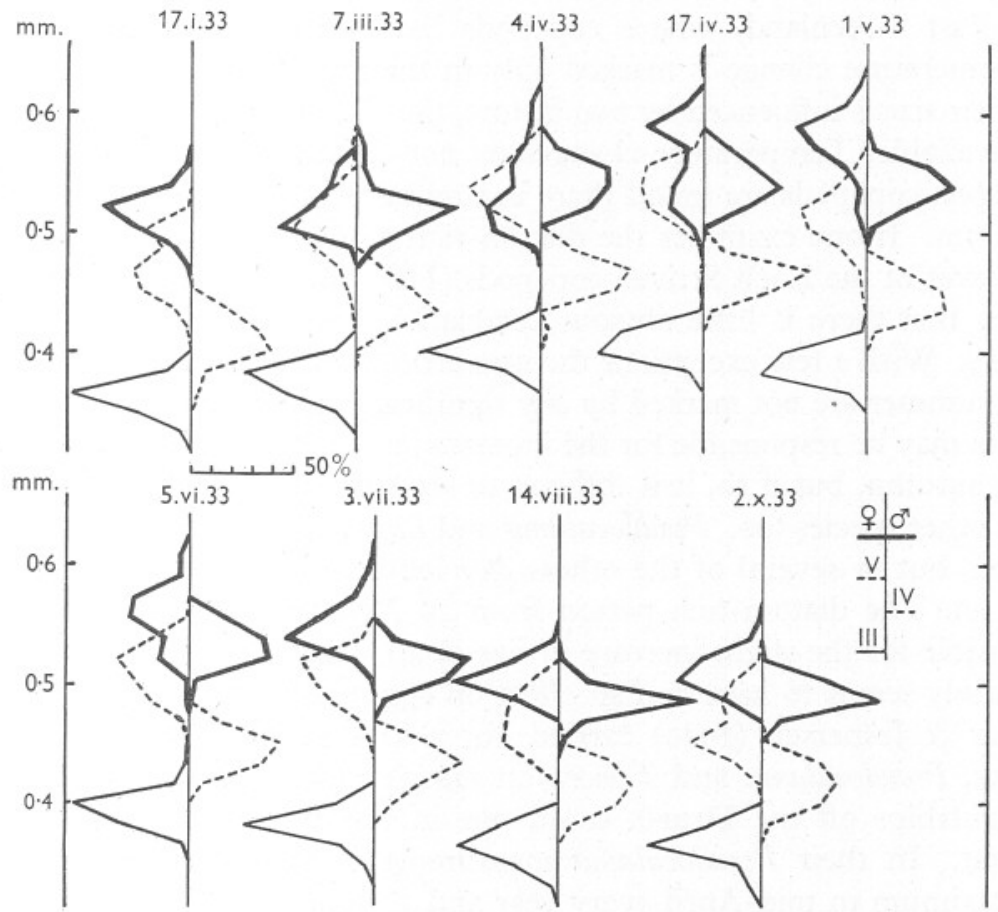

Fig. 29. Oithona similis. Percentage size distribution of Stages III-VI on selected dates. JOURN. MAR. BIOL. ASSOC. vol. XXVIII, I949 
Stage $\mathrm{V}$ of the spring brood had appeared. At this time the size-frequency curves for females show two modes, one belonging to the new large-sized brood, and one to the old small-sized brood (Table XVI). The female stock as a whole shifts from the old to the new mode during 27 March to 24 April, so that the fact that the median size of the Stage $V$ is larger than that of the female merely means that the new-brood Stage V is larger than the old-brood females.

In every copepod species the maximum size was reached on the appearance of the spring brood in April. This brood hatched and grew up during that time of year when the sea was at its coldest. It was also a time of abundant diatoms, so that both low temperature and rich food supply may be held accountable.

In Calanus it was supposed (Marshall et al., 1934) that the decrease in size during the summer was temporarily checked on the appearance of each new brood. This was certainly not true of the small copepods. In them the slight increases in size which occurred during the summer were hardly significant and bore no relation to broods. Even Microcalanus, which in its reproduction resembled Calanus closely, showed no comparable size changes. Only in the Temora females of the second brood on 15 May was there an increase in size, but this was based on the measurement of ten specimens only.

In East Greenland, where copepods have only one brood a year and the temperature change is marked only in the top Io m., Ussing (1938) says that their size is influenced by two factors, the size at moult and the amount of food available. Temperature changes do not explain the size differences, for the largest copepods are found there in summer when the temperature is at its maximum. If one examines the diatom-rich periods along with the mediansize curves of the Loch Striven copepods (Figs. I6, I8, 20, 22, 26, 28), it will be seen that there is little obvious correlation apart from the spring diatom increase. With a few exceptions the numerous diatom increases in the course of the summer are not marked by any significant changes in size. The August diatoms may be responsible for the increase in size of Centropages and Temora in late autumn, but if so, it is difficult to see why they did not have an effect on the other species too. Pseudocalanus and Paracalanus had stopped breeding by then, but in several of the others development seemed to have been still going on. The diatom-rich period from 29 May to 5 June may have been responsible for the slight increase in size of all stages of Oithona at that time; it certainly seems to have had an effect on egg production.

Adler \& Jespersen (1920) carried out a long series of measurements of Calanus, Pseudocalanus and Temora on samples taken for several years from two lightships off the Danish coast, one in the North Sea and one in the Kattegat. In their Pseudocalanus measurements there was a very marked size maximum in mid-April every year and a more gradual decline, showing numerous irregularities, to a minimum in August. In the North Sea this 
minimum size was retained all winter and there was no increase till the following March. In the Kattegat, however, in two of the three autumns the size increased sharply again in October and November and rose more or less steadily till April. It seems possible that breeding there continued later into the winter and that the lower temperatures then had an effect on the size of the developing copepods, but there is no obvious reason for a late brood. On the whole, however, the size changes agree very well with those found in Loch Striven except that in their samples the male is always about $0.1 \mathrm{~mm}$. smaller than the female, and this difference is maintained throughout the year.

In Temora (adults only were measured) they found two maxima in the year, one in spring and the other in winter, usually December. This second maximum was sometimes even larger than the spring one, and perhaps indicated breeding during the winter. The measurement of the Loch Striven samples was not carried on far enough into the winter to see whether the size increase shown in the end of August continued. The actual sizes of the copepods were much the same in all three places, those from the North Sea being on an average rather larger than those from the Kattegat, and those from the Kattegat in turn rather larger than those from Loch Striven.

\section{FoOD AND FEEDING}

In examining the samples for measurement a note was kept of any copepods with food pellets in the gut. The copepods had been in preservative for up to Io or I2 years, and the body was often opaque, making the gut difficult or impossible to see. No great reliance can be put therefore on the figures for the percentage feeding, and it seemed to have very little relation to the times of diatom increase. The greatest differences were found between one species of copepod and another. Thus Temora and Centropages always had a much larger percentage feeding than any of the other species, a fact which confirms observations made on living specimens (Lebour, 1922; Marshall, 1924). On the whole fewer males were seen with food than any of the other stages, and this is what might be expected from their shorter life and specialized function. In some copepods, e.g. Euchaeta norvegica (Sars, I903; Nicholls, 1934), the male has much reduced mouthparts.

The results of some examinations of the gut contents of living copepods, taken from near the Marine Station, Millport, is shown in Table II. Most of these observations were made in autumn and winter, few in spring or summer. It will be noted that Centropages and Temora have again a larger proportion feeding than Pseudocalanus and Acartia.

As with Calanus, the food actually observed does not seem enough to meet the requirements, and the question remains whether or not the copepods depend largely on the minute naked flagellates about whose abundance and variations in the sea so little is known. Minute flagellates were counted in the 
I933 centrifuged water samples (Marshall et al., I934, p. 824), but centrifuging is not a reliable method for these very small forms, and the figures given may bear little relation to their real abundance. It is perhaps not surprising, therefore, that no relation can be seen between their numbers and copepod size or breeding.

\begin{tabular}{|c|c|c|c|c|c|c|}
\hline Species & $\begin{array}{l}\text { No. } \\
\text { examined }\end{array}$ & $\begin{array}{l}\text { Empty or food } \\
\text { indistinguishable }\end{array}$ & Diatoms & $\begin{array}{l}\text { Radio- } \\
\text { larians }\end{array}$ & $\begin{array}{c}\text { Flagel- } \\
\text { lates }\end{array}$ & Crustacea \\
\hline Pseudocalanus & 102 & 73 & I8 & 4 & I & IO \\
\hline Microcalanus & I6 & I5 & I & 0 & 0 & 0 \\
\hline Centropages & 8 & 2 & 3 & 0 & 2 & 6 \\
\hline Temora & 43 & 5 & 28 & 9 & 7 & I8 \\
\hline Acartia & 88 & 59 & I8 & 3 & I & 9 \\
\hline
\end{tabular}

Sixteen Oithona females were examined, but they contained only indistinguishable debris.

\section{PARASITES}

Pseudocalanus was the only copepod in which parasites were observed, and it seems to be less subject to them than Calanus. A trematode has occasionally been seen in its body cavity (although not in the Loch Striven samples), but the internal dinoflagellate parasites so common in Calanus (Jepps, I937) are rare. Ten specimens were seen carrying Ellobiopsis and, as usual, most of these were on females (4 on Stage V female, I on Stage V male, and 5 on adult female). A Microniscus sp. was found on one female.

\section{COMPARISON WITH OBSERVATIONS ELSEWHERE}

Pseudocalanus. Among the pelagic copepods, Pseudocalanus minutus, because of its large numbers, is perhaps the most important species after Calanus, and its breeding and size variations have been studied in numerous places in the North Atlantic. The general course of its growth and development there is remarkably uniform. In Loch Striven, off the Norwegian coast (Oslo Fjord, Wiborg, 1940; Herdla and Hjelte Fjords, Runnström, 1932; off Möre, Ruud, 1929), and in the seas between Norway and Iceland (Störmer, I929), reproduction begins in early spring, usually at the time of the phytoplankton increase, and goes on throughout the summer. The maximum numbers occur, not with the first brood, but during the summer, and by July or August the stock is mainly in the late copepodite stages and will pass the winter thus. In Nordåsvatn, however, Stage III is the most abundant stage from August to December (Wiborg, I944). In the most southerly area investigated, the Gulf of Maine, much the same holds good (Fish, 1936b); reproduction begins with the spring increase and there are three or four broods during the summer and autumn, of which the second is the largest, but the copepod almost disappears from inshore waters from July to October. Fish supposes that rising temperature is the cause of this and that they move into deeper water offshore. 
In the most northerly part of the area, East Greenland, conditions are rather different (Ussing, I938). Most of the stock spends the winter in deep water (below $50 \mathrm{~m}$.) and rises above this only from June to August. Reproduction begins soon after, but in the cold water there development is slow and there is only one brood a year, although a few individuals may possibly grow fast enough to reproduce in the same summer that they are hatched. Early copepodite stages are found throughout the winter, and even Stage II does not entirely disappear till March of the year following that in which it is hatched. The temperature below $50 \mathrm{~m}$. differs little from that above except near the surface during the summer, and Ussing ascribes the seasonal vertical migrations to the influence of light.

Pseudocalanus is found at all depths, but as a rule is more abundant near the surface, i.e. above $50 \mathrm{~m}$., and even above $20 \mathrm{~m}$. (Ruud, I929). According to Runnström (I932) it avoids the layers above Io m., but this was not so in Loch Striven. Ruud records that in 1927 at two Stations it was more numerous below than above $50 \mathrm{~m}$. in May, June and July. Where vertical hauls have been taken in sections the division has commonly been made much deeper than Io m., so that the seasonal migration above and below ro $\mathrm{m}$. found in Loch Striven cannot be confirmed from elsewhere. In Nordåsvatn, a land-locked fjord near Bergen, Pseudocalanus was often found above $15 \mathrm{~m}$., and there were considerable alterations in vertical distribution from time to time (Wiborg, I944). Hydrographical conditions were, however, so different (well-marked layering, and lack of oxygen in deep water) that the two areas can hardly be compared.

In the Barents Sea (Bogorov, I932) the depth distribution was peculiar in that there were maxima at I0-25 and I00-160 m., with an intervening minimum. The upper maximum is composed of Stages I-V, the lower of Stages III-VI.

Paracalanus. In Norwegian waters (Runnström, I932; Wiborg, I940) Paracalanus is scarce throughout the winter and has a maximum in late summer as in Loch Striven.

Microcalanus. This copepod, owing to its small size, will slip through the meshes of most nets and has not been taken into account in most plankton hauls. There are, however, some data on its occurrence off the Norwegian coast (Ruud, I929; Runnström, I932; Wiborg, I940), and from the Michael Sars expedition (Störmer, I929). It is generally agreed to be a deep-water form living mainly below $50 \mathrm{~m}$. Runnström states that in autumn and winter (in the Herdla and Hjelte Fjords) it is numerous also from Io to $50 \mathrm{~m}$., and that from May to August it is found mainly below Ioo m. Störmer mentions the possibility that it may make diurnal vertical migrations. The dates of spawning, which they judged mainly from the presence of males or of females carrying spermatophores, agree well with those in Loch Striven, March (off Möre), or February to April (Oslo Fjord), May (Herdla and Hjelte Fjords), May to June 
(off Möre), or June (Oslo Fjord), October to November (Oslo Fjord). Wiborg remarks on the periodicity of the spawning, and his late autumn date is perhaps an indication that spawning can go on during the winter. There was in the Loch Striven samples, however, no clear development from the nauplii even as early as August.

In the fjords of East Greenland (Ussing, 1938) Microcalanus was found above $50 \mathrm{~m}$. only in winter (November to May). It spawned in the early months of the year (January to March), but this was probably not the main spawning time. Owing to its withdrawal into deep water during the summer, its complete life history there could not be ascertained.

Centropages hamatus. This is a coastal form living near the surface and there are few observations on it in the literature. Wiborg (I940), working in the Oslo Fjord, says that the chief spawning is in March or April, but that there is some also in summer. The maximum numbers are in June and July when adults and copepodites predominate. On the whole this agrees fairly well with Loch Striven. Otten (19I3) says that in Kiel Bay its numbers increase gradually till June, decrease, and then increase again in September. As already mentioned (p. 59) he found a large number of nauplii but no copepodites in the end of September and even in November.

In the zooplankton of the Gulf of Maine (Fish \& Johnson, 1937) C. hamatus was not present but $C$. typicus occurred, and they mention the possibility of its having a 'winter egg' since the species is sparse or absent most of the year.

Temora. Like Centropages, Temora is a neritic form, living near the surface, abundant as a rule only in summer. In the Oslo Fjord (Wiborg, I940) it was scarce during the winter and numerous from April till July. The maximum numbers in the outer fjord were found in April and July, and the main spawning was (as in Loch Striven) in April. Nauplii were found all the year round, and adults were more numerous from June to October. This was not so in Loch Striven, nor was the proportion of adults higher than in the other species. Males outnumber females in the Oslo Fjord but not, according to Otten (1913) in Kiel Bay (see Table I). There reproduction probably went on late into the winter, since maxima of copepodites were found in June, September and also December.

Acartia. In the Oslo Fjord (Wiborg, 1940), as in Loch Striven, Acartia had a late summer maximum in numbers and decreased very much from December to June. In other areas, however, such as the Herdla and Hjelte Fjords (Runnström, 1932) and off Möre (Ruud, I929), there were two maxima, the first in April to May or May to June and the second in July or August to November. Off Möre there were several broods in the year beginning in March to April. Acartia has usually been found between 0 and $100 \mathrm{~m}$., but in autumn was found also down to $200 \mathrm{~m}$.

On the east coast of America this species occurs as an inshore form. South of Cape Cod (Fish \& Johnson, I937) it forms an important part of the neritic 
community in winter, but to the north it has its maximum in late summer and usually spawns then. It is occasionally found to spawn in early spring there also, but this may be an extension of the winter breeding centred to the south of Cape Cod.

Oithona similis. This is a very widely distributed species, and its seasonal variation in numbers has been studied in the Gulf of Maine (Fish, I936c) as well as in the North Atlantic and on the Norwegian coast.

In Norwegian waters the species is found down to $400 \mathrm{~m}$., although it is commonest near the surface. It occurs all the year round and has two maxima in numbers, one in March to May, the other July to August, the date varying from year to year.

Otten (I9I3), working in Kiel Bay, finds rather different conditions, for he states that maximum numbers occur in April and in October with a minimum in August. This indicates a condition very different from Loch Striven where the maximum comes in August.

Fish (I936c) finds that in the Gulf of Maine, as in Loch Striven, eggs and nauplii make up a large proportion of the total catch throughout the year, indicating a heavy mortality in these stages. He suggests, however, that development takes as long as 2 months in winter and 6 weeks in summer, which seems decidedly too long for the Loch Striven Oithona. Breeding in the Gulf of Maine as in Loch Striven begins in March, and three or four broods are produced from then till September. The maximum number occurs in August.

\section{Discussion}

The importance of a copepod in the ecology of the plankton cannot be judged from its numbers alone; its size must also be taken into account. Very little is known about the weights of the small copepods. Bogorov and Preobraijenskaya (I934) have published a few data for Pseudocalanus elongatus (Stages V and VI), Centropages hamatus (Stage VI) and Acartia longiremis (Stage VI), giving the average dry weights as 0.07-0.09, 0.II and 0.012 $\mathrm{mg}$. respectively. Lohmann (I908) has given calculated volumes in cubic microns for most of the common species, but his relative values (which are rough averages from nauplius as well as copepodite stages) do not agree very well with the Loch Striven sizes. His volumes for the different species in cubic millimetres are as follows: Temora, 0.026; Centropages hamatus, 0.025; Pseudocalanus, 0.0235; Acartia, 0.014; Paracalanus parvus, 0.006; Oithona similis, 0.003 . In this series Temora seems too large and Acartia too small; Microcalanus would presumably be slightly larger than Oithona. He does not give Calanus either, and it is probably at least ten times the volume of Pseudocalanus. Fig. 30 shows the numbers of the seven species of copepod in Loch Striven throughout the year, all drawn on the same scale. Taking Lohmann's values for volume it is found that (apart from Calanus) Pseudocalanus, because of its size and abundance, is by 


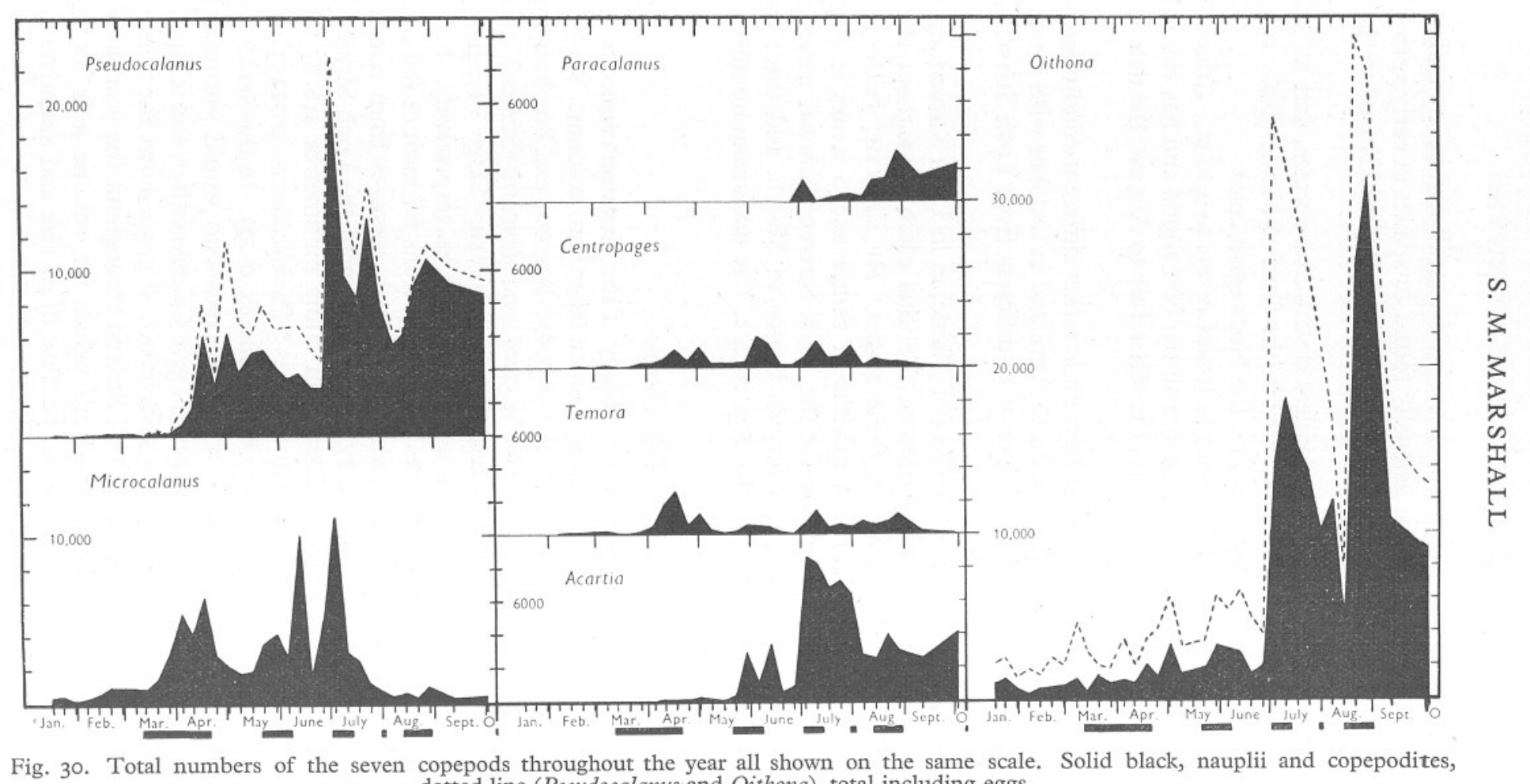

Fig. 30. Total numbers of the seven copepods throughout the year all shown on the same scale. Solid black, nauplii and copepodites,
dotted line (Pseudocalanus and Oithona), total including eggs. 
far the most important, Acartia (even at Lohmann's low assessment) comes next, and Oithona, because of its high numbers, third. Microcalanus, Temora and Centropages are all much the same and considerably less than Oithona. This gives a rough idea of the amount of animal food each copepod species can provide. Paracalanus is omitted, since it did not become common till July and may have been more important after observations stopped in October. The different stages and species of copepod are, however, eaten by different sizes of fish, the smallest stages providing food for the larvae and the largest for post-larval or even adult fish. Some of this food is available all the year round, but it is most abundant from April on throughout the summer when most young fish are growing.

The life histories of all the copepods so far examined resemble one another in their general features and differ only in detail. Each shows a succession of broods throughout the summer, sometimes distinct but more often running into one another. The dates on which breeding begins and stops vary from year to year and from place to place. The usual number of broods is three or four, but in the cold waters of the far north this may be reduced to one. Since work in Loch Striven stopped in October it is not possible to say for every species whether breeding continued after this date or not. In Calanus, Pseudocalanus and Paracalanus it certainly did not, for by that time a large stock (40-80\% of the total catch of each) of Stages IV or V had been built up, and further development had obviously stopped. In the other copepods a much larger proportion of nauplii was present in October (about $75 \%$ in Microcalanus, Centropages and Temora), and although breeding did not seem to be going on it was still a possibility. In Acartia and Oithona the percentage of nauplii in October was about $40 \%$, much lower than was found in January to March. Here, too, further breeding was still possible. The stage in which the winter is passed may therefore vary in different species of copepod, and further work is needed to elucidate this.

The sequence of events described, although true for 1933, may not be followed every year. It is known from unpublished observations in Loch Striven and at Millport that, for instance, Microcalanus is not always one of the common copepods, and that the order of appearance and relative abundance of the different species is not always the same. It would therefore be very interesting to have detailed studies of the copepods, not only from different areas, but from the same area in different years.

The vertical distribution of the copepods in Loch Striven was rather different from that described elsewhere, mainly perhaps because the loch is, comparatively speaking, shallow, and the great depths at which they are sometimes found do not occur there. In Loch Striven all but Microcalanus followed the same pattern; they were all near the surface till July, and then the older stages were mainly in deeper water for at least a few weeks and in some species a few months. 
The seasonal size variations, too, resembled each other closely in all species examined and agreed with what has been found elsewhere. The different species do not all grow at the same rate. Fig. 3I shows the median size of all the copepodite stages of all the copepods on 3 July (see also Table XVII), a date when they were numerous enough to measure, and Fig. 32 shows the maximum and minimum sizes reached during the year by each stage. It

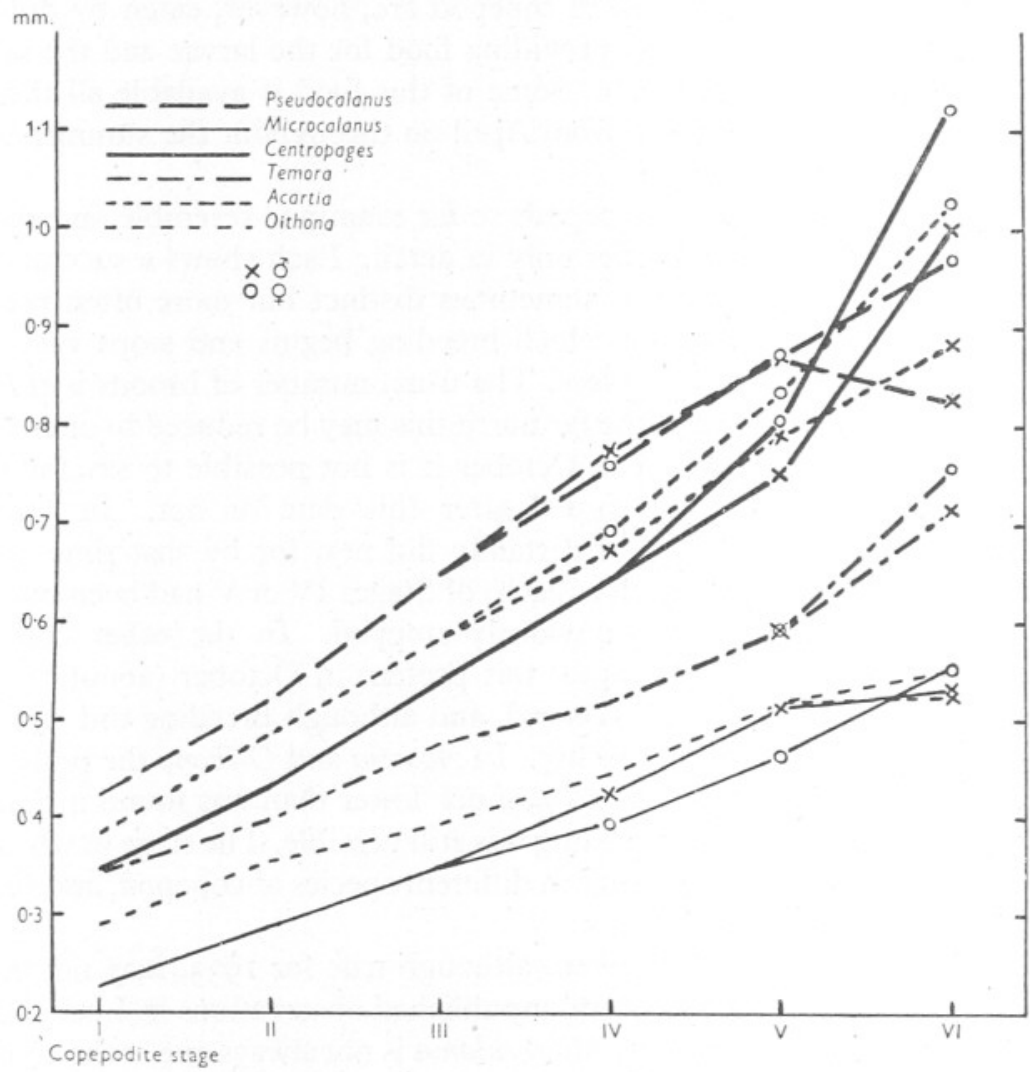

Fig. 3I. Median size of copepodite Stages I-VI of six copepod species on 3 July.

can be seen from Figs. 31 and 32 that whereas Oithona doubles its length from Stage I to the largest Stage VI, Pseudocalanus, Microcalanus, Temora and Acartia about treble it and Centropages quadruples it. From Stage I to Stage V (Fig. 3I) Pseudocalanus and Acartia are about the same size as Centropages, but in the adult, Centropages is the largest.

The points for the median lengths of the stages in each copepod lie on a more or less straight line up to Stage V, but beyond this the different species vary. In Centropages there is a marked, and in Temora and Acartia a slight, rise in the curve from Stages V to VI, in each case greater in the female than 


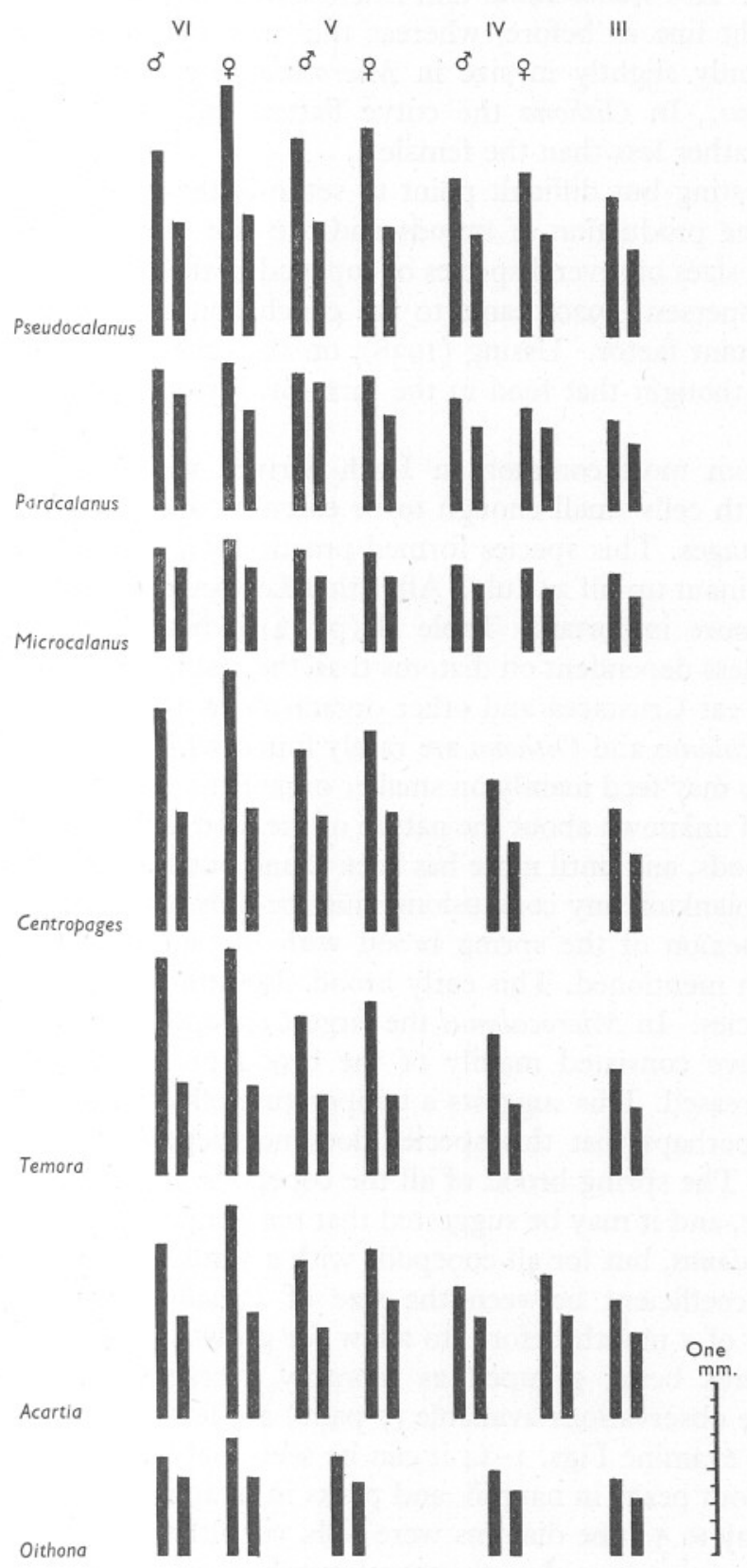

Fig. 32. Maximum and minimum sizes of copepodite Stages III-VI in seven species. 
in the male. In Pseudocalanus and Microcalanus the female continues on the same straight line as before, whereas the male curve flattens off, the male increasing only slightly in size in Microcalanus and actually decreasing in Pseudocalanus. In Oithona the curve flattens off in both sexes, the male increasing rather less than the female.

An interesting but difficult point to settle is the relation between diatom increases, the production of broods and the size of the copepods. In their study of the sizes of several species of copepod in the North Sea and Kattegat, Adler \& Jespersen (1920) came to the conclusion that temperature was the most important factor. Ussing (1938), on the other hand, working off East Greenland, thought that food in the form of phytoplankton was much more important.

The diatom most common in Loch Striven was Skeletonema costatum, a species with cells small enough to be eaten by all the copepods at least in their later stages. This species formed practically all the spring increase and was predominant up till 24 July. After that Leptocylindrus sp. and Chaetoceros spp. were more important. Table II (p. 84) indicates that Centropages and Temora are less dependent on diatoms than the rest because they are voracious feeders and eat Crustacea and other organisms as well as diatoms, and that, since Microcalanus and Oithona are rarely found with recognizable remains in the gut, they may feed mainly on smaller organisms such as minute flagellates. Much is still unknown about the nature of the food and the food requirements of the copepods, and until more has been found out about the relation of these to the nanoplankton any conclusions must be only tentative.

The connexion of the spring brood with the spring diatom increase has already been mentioned. This early brood also attained the largest size in all but one species. In Microcalanus the largest copepods occurred during April and may have consisted mainly of the brood produced before the spring diatoms increased. This suggests a temperature effect rather than a rich food supply, or perhaps that this species does not depend on diatoms for food (see above). The spring brood of all the copepods grew up when the sea was at its coldest, and it may be suggested that temperature is important, not only for Pseudocalanus, but for all copepods with a similar size curve. Indeed, the correlation coefficient between the size of Pseudocalanus females and the temperature of a month before (to allow for growth from egg to adult), both sets of figures being grouped as monthly averages, is significant (0.88), although the observations available (7 pairs) are few.

When we examine Figs. I-I4 it can be seen that there are both diatom increases without peaks in nauplii, and peaks in nauplii when diatoms are poor. From 22 May to 5 June diatoms were rich, yet although there were increases both in the proportion and in the actual number of nauplii (Pseudocalanus was an exception), no brood grew up. The diatom increase on 3 to Io July, on the other hand, was accompanied in almost every copepod by an increase in nauplii 
from which a brood grew up. The very short-lived diatom increase on 3I July (I64 cells $/ \mathrm{ml}$. at the surface only) had no effect except a possible increase of nauplii in Centropages. The larger and more prolonged increase from I4 to 28 August was again accompanied by an increase in nauplii in every copepod, but since breeding at that time was more or less continuous it is doubtful whether an increase in the number of older stages resulted.

On the other hand, on I May, when diatoms were poor, there was a peak of nauplii followed by a brood in Centropages, Temora and possibly Oithona. These are, however, three of the copepods which may be less dependent on diatoms for food than are the others (Table II, p. 84).

On the whole, then, it does seem that the presence of diatoms increases the production of eggs and nauplii and helps the development of the later stages.

\section{SUMMARY}

The seven species of small copepod common in Loch Striven have been studied from vertical tow-net hauls taken there throughout the year 1933. These copepods were Pseudocalanus minutus, Paracalanus parvus, Microcalanus pygmaeus, Centropages hamatus, Temora longicornis, Acartia clausi and Oithona similis.

In general, the copepods began to reproduce about the time of the spring diatom increase in March or April, and produced a succession of broods throughout the summer; apart from the first these broods were not as a rule so clearly marked as in Calanus. Microcalanus begins to breed before the spring increase and has clearly marked broods like Calanus.

The numbers of males and females were about equal until the adult stage, when the proportions varied greatly between one species and another.

The number of eggs laid per female was counted in Pseudocalanus and Oithona and it varied throughout the year. The number is closely correlated with the size of the female and may bear some relation to the amount of phytoplankton present.

With the exception of Microcalanus all the copepods showed a seasonal vertical migration. From April till the beginning of July they were found mainly above Io $\mathrm{m}$. and in July and August mainly below. The migration was more marked in some species than in others and, as in Calanus, the younger stages showed it less than the older. Microcalanus stayed below Io m. almost entirely from April to August.

The size of copepodite Stages III-VI was measured throughout the year. In most species there was a well-marked maximum in spring and a gradual decrease till the autumn. The relative size of male and female in copepodite Stages IV-VI is different in different species.

Observations in Loch Striven are compared with those made on the same copepods elsewhere.

The relationship between reproduction, size and phytoplankton is discussed. 


\section{REFERENCES}

AdLeR, G. \& JeSPERSEN, P., I920. Variations saisonnières chez quelques copépodes planctoniques marins. Medd. Komm. Danmarks Fisk. Havund., Kobenhavn, Ser. Plankton, Bd. II, No. I, 46 pp.

Bogorov, B. G., 1932. Materials on the biology of the copepodes of the Barents and the White Seas. Bull. State Oceanog. Inst. Moscow, Vol. 4, pp. I-I6.

Bogorov, B. G. \& Preobraijenskaya, E., I934. On the weight characteristics of the plankton organisms of the Barents Sea. II. Copepoda. All-union Sci. Res. Inst. Mar. Fisheries and Oceanography, Bull. No. 2, pp. I-29.

Fish, C. J., I936a. The biology of Calanus finmarchicus in the Gulf of Maine and Bay of Fundy. Biol. Bull., Wood's Hole, Vol. Lxx, pp. II8-4I.

Fish, C. J., I936b. The biology of Pseudocalanus minutus in the Gulf of Maine and Bay of Fundy. Biol. Bull., Wood's Hole, Vol. Lxx, pp. I93-216.

Fish, C. J., I936c. The biology of Oithona similis in the Gulf of Maine and Bay of Fundy. Biol. Bull. Wood's Hole, Vol. Lxxi, pp. I68-87.

Fish, C. J. \& JoHnson, M., I937. The biology of the zooplankton population in the Bay of Fundy and Gulf of Maine with special reference to production and distribution. Fourn. Biol. Board Canada, Vol. III, pp. I89-322.

Jepps, M. W., I937. On the protozoan parasites of Calanus finmarchicus in the Clyde Sea Area. Quart. F. Micr. Sci., Vol. 79, pp. 589-658.

KRAEFFT, F., I9IO. Über das Plankton in Ost- und Nordsee und den Verbindingsgebieten mit besonderer Berücksichtigung der Copepoden. Wiss. Meeresunters. Komm. wiss. Unters. deutsch. Meere Kiel u. Biol. Anst. Helgoland, Abt. Kiel, Bd. XI, pp. 29-99.

Lebour, M. V., I922. The food of plankton organisms. Fourn. Mar. Biol. Assoc., Vol. xII, pp. 644-77.

LohmanN, H., I908. Untersuchungen zur Feststellung des vollständigen Gehaltes des Meeres an Plankton. Wiss. Meeresunters. Komm. wiss. Unters. deutsch. Meere Kiel. u. Biol. Anst. Helgoland, Abt. Kiel, Bd. x, pp. I29-370.

Marshall, S., I924. The food of Calanus finmarchicus during 1923. Fourn. Mar. Biol. Assoc., Vol. xiII, pp. 473-79.

MARShall, S., I933. On the biology of Calanus finmarchicus. II. Seasonal variations in the size of Calanus finmarchicus in the Clyde Sea-Area. Fourn. Mar. Biol. Assoc., Vol. xIx, pp. II I-38.

Marshall, S. M., Nicholls, A. G. \& OrR, A. P., I934. On the biology of Calanus finmarchicus. V. Seasonal distribution, size, weight and chemical composition in Loch Striven in 1933, and their relation to the phytoplankton. Fourn. Mar. Biol. Assoc., Vol. xIX, pp. 793-828.

Nicholls, A. G, I933. On the biology of Calanus finmarchicus. I. Reproduction and seasonal distribution in the Clyde Sea-Area during 1932. Fourn. Mar. Biol. Assoc., Vol. xIX, pp. 83-I Io.

Nicholls, A. G., I934. The developmental stages of Euchaeta norvegica, Boeck. Proc. Roy. Soc. Edin., Vol. LIV, pp. 3I-50.

Oberg, M., I906. Die Metamorphose der Plankton-Copepoden der Kieler Bucht. Wiss. Meeresunters. Komm. wiss. Unters. deutsch. Meere Kiel u. Biol. Anst. Helgoland, Abt. Kiel, Bd. Ix. pp. 37-I75.

OtTeN, P., I9I3. Quantitative Untersuchungen über die Copepoden des Fehmarnbeltes und ihre Entwicklungsstadien. Wiss. Meeresunters. Komm. wiss. Unters. deutsch. Meere Kiel u. Biol. Anst. Helgoland, Abt. Kiel, Bd. xv, pp. 249-302.

Rosendorn, I., I927. (Copepoda I): Die Gattung Oithona. Wiss. Ergeb. deutsch. Tiefsee Exp. Dampf. 'Valdivia' I898-1899, Bd. xxIII, pp. I-58. 
Runnström, S., 1932. Eine Uebersicht über das Zooplankton des Herdla- und Hjeltefjordes. Bergens Museums Arbok, I931, No 7,67 pp.

Ruud, J. T., 1929. On the biology of copepods off Møre 1925-27. Cons. Perm. Internat. Explor. Mer: Rapp. Proc. Verb. Vol. LvI, 84 pp.

SARs, G. O., I903. An account of the Crustacea of Norway. IV. Copepoda Calanoida. Bergen.

Sars, G. O., I9I8. An account of the Crustacea of Norway. VI. Copepoda Cyclopoida. Bergen.

StöRmer, L., I929. Copepods from the 'Michael Sars' expedition, I924. Cons. Perm. Internat. Explor. Mer: Rapp. Proc. Verb., Vol. Lvi, 57 pp.

Ussing, H. H., I938. The biology of some important plankton animals in the fjords of East Greenland. Medd. om Gronland, Bd. I00, pp. I-I08.

WIBORG, K. F., I940. The production of zooplankton in the Oslo Fjord in 1933-34 with special reference to the copepods. Hvalrådets Skrifter, Nr. 2I, 87 pp.

WIBorG, K. F., I944. The production of zooplankton in a land-locked fjord the Nordåsvatn near Bergen, in I94I-42 with special reference to the copepods. Rep. Norwegian Fishery Mar. Investigations, Vol. viI, No. 7, 83 pp.

WILsON, C. B., I932. The copepods of the Woods Hole region Massachusetts. Smiths. Inst. U.S. Nat. Mus. Bull., Vol. 158, pp. I-635.

WINSOR, C. P. \& WALFORD, L. A., I936. Sampling variations in the use of plankton nets. Fourn. Conseil Internat. Explor. Mer., Vol. xI, pp. I90-204.

With, C., I9I5. Copepoda I. Calanoida Amphascandria. Danish Ingolf Exp., Vol. III, No. 4, 260 pp. 


\section{APPENDIX}

TAble III. Pseudocalanus minutus. Number Per haul

\begin{tabular}{|c|c|}
\hline Date & $\begin{array}{l}\text { Haul, deptl } \\
\text { in } \mathrm{m} \text {. }\end{array}$ \\
\hline 17. i & $\| \mathrm{B}-\mathrm{O}$ \\
\hline $23 . \mathrm{i}$ & $\mathrm{B}-\mathrm{O}$ \\
\hline 30. i & B-o \\
\hline 6. ii & $\mathrm{B}-\mathrm{O}$ \\
\hline I3. ii & $\mid \mathrm{B}-\mathrm{O}$ \\
\hline 20. ii & B-O \\
\hline 27. ii & B-o \\
\hline 7. iii & $\mathrm{B}-\mathrm{O}$ \\
\hline I3. iii & $\| \mathrm{B}-\mathrm{O}$ \\
\hline 20. iii & $\S \mathrm{B}-\mathrm{O}$ \\
\hline 27. iii & $\left\{\begin{array}{l}\text { B-IO } \\
\text { IO-O }\end{array}\right.$ \\
\hline iv & B-10 \\
\hline 4.10 & \{10-0 \\
\hline Io. iv & (B-IO \\
\hline & Iro-o \\
\hline I7. iv & $\left\{\begin{array}{l}\mathrm{B}-\mathrm{IO} \\
\mathrm{O}-\mathrm{O}\end{array}\right.$ \\
\hline 24 iv & B-IO \\
\hline & $\left\{\begin{array}{l}\text { \{0-0 } \\
\text { Io- }\end{array}\right.$ \\
\hline 24. iv & SU.H. B-o \\
\hline I. $\mathrm{V}$ & $\left\{\begin{array}{l}B-0 \\
10-0\end{array}\right.$ \\
\hline 8. $\mathrm{v}$ & B-IO \\
\hline 8. $\mathrm{v}$ & SU.H. B-o \\
\hline I5. $\mathrm{v}$ & $\ddagger \mathrm{B}-\mathrm{O}$ \\
\hline 22. V & $\left\{\begin{array}{l}B-10 \\
10-0\end{array}\right.$ \\
\hline 22. V & SU.H. B-o \\
\hline 29. V & B-Io \\
\hline & Iro-o \\
\hline $5 . \mathrm{vi}$ & $\left\{\begin{array}{l}B-10 \\
\text { IO-O }\end{array}\right.$ \\
\hline 5. vi & §U.H. B-o \\
\hline
\end{tabular}

(For meaning of symbols see end of table)

\begin{tabular}{|c|c|c|c|c|c|c|c|c|c|c|c|}
\hline & & & & & & & & & eggs & & \\
\hline$\hat{\sigma}$ & 우 & V & IV & III & II & I & $\mathrm{N}$ & Eggs & per sac & To & $a a^{\star}$ \\
\hline I & 8 & 30 & 2 & I & I & .. & I6 & V. few & $\cdots$ & & 59 \\
\hline I & II & 27 & I & I & I & 3 & 46 & I6 & .. & & $9 \mathrm{I}$ \\
\hline 3 & 9 & I7 & I & I & I & 2 & 28 & 9 & .. & & 62 \\
\hline 5 & 15 & 12 & I & .. & I & I & 43 & 39 & $\cdots$ & & 78 \\
\hline I & 12 & 4 & I & I & . & 4 & $6 \mathrm{I}$ & 27 & 9.5 & & 84 \\
\hline . & 7 & 2 & I & 3 & 9 & 17 & I78 & 26 & 10.6 & & 217 \\
\hline$\ldots$ & 8 & 4 & 2 & 9 & 12 & I5 & II 2 & 29 & 10.0 & & 162 \\
\hline . & I5 & 7 & 3 & 5 & 5 & I4 & I5 & 6I & II $\cdot 8$ & & 203 \\
\hline .. & Io & 6 & I & 2 & 3 & I3 & 95 & I6 & $12 \cdot 6$ & & 130 \\
\hline 3 & I5 & 9 & 8 & I9 & 25 & $2 I$ & 214 & 79 & I5:3 & & 3 I4 \\
\hline . & I & $\because$ & 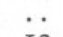 & 2 & 4 & 3 & I9 & .) & $32 \cdot 5$ & 29). & 237 \\
\hline .. & I & I0 & I3 & II & I3 & 38 & 122 & 26 ? & & $208\}$ & \\
\hline$\ldots$ & I3 & 17 & I & 3 & I & 2 & 23 & $206 !$ & $32 \cdot 3$ & $60)$ & $67 I$ \\
\hline 20 & 53 & 85 & 45 & 29 & I4 & 7 & 358 & 657 ! & 323 & 6II & \\
\hline 3 & 12 & 2 & I & . & $\because$ & I & 95 & I29! & & II 4 ? & I69I \\
\hline 24 & 34 & 20 & II & II & I 7 & 90 & I370 & 580 & 37.1 & I 577$\}$ & 1091 \\
\hline 4 & 8 & 6 & I & 6 & I & 7 & 276 & $85 !$ & 38.4 & 309! & 6078 \\
\hline 57 & II 8 & 90 & IOI & 143 & 230 & 540 & 4490 & I878\} & 304 & 5769 ) & \\
\hline 83 & 3 & $\begin{array}{r}5 \\
88\end{array}$ & I & 3 & I & 8 & 330 & $\begin{array}{r}6 \mathrm{I} \\
2\end{array}$ & $36 \cdot 4$ & 35I & 3471 \\
\hline $\begin{array}{l}83 \\
53\end{array}$ & II6 & 158 & I75 & 259 & 192 & I67 & 1970 & $\begin{array}{r}7121 \\
583\end{array}$ & $36 \cdot 0$ & 31201 & 3263 \\
\hline $\begin{array}{l}53 \\
74\end{array}$ & $\begin{array}{r}153 \\
50\end{array}$ & $\begin{array}{r}138 \\
20\end{array}$ & $\begin{array}{r}188 \\
66\end{array}$ & $\begin{array}{r}200 \\
90\end{array}$ & $\begin{array}{l}163 \\
\text { I18 }\end{array}$ & $\begin{array}{l}193 \\
136\end{array}$ & $\begin{array}{l}2175 \\
2270\end{array}$ & $\begin{array}{r}1583 \\
924 !\end{array}$ & $30 y$ & 2824! & 3203 \\
\hline II 5 & 256 & 288 & 236 & 222 & 212 & 165 & 1930 & $4545\}$ & $33 \cdot 3$ & $3424\}$ & 6248 \\
\hline I & 2 & 2 & I & 3 & 4 & I7 & 240 & $25\}$ & $28 \cdot 8$ & 270 & 8863 \\
\hline I88 & 630 & 810 & 445 & 425 & 555 & 750 & 4790 & 60151 & 200 & $8593\}^{\prime}$ & \\
\hline 133 & 300 & 308 & 235 & I 48 & 245 & 388 & 2150 & 3037 & $29 \cdot 3$ & & 3907 \\
\hline 90 & 97 & 152 & 208 & 230 & 243 & 136 & 3920 & I 108 & 24.5 & & 5076 \\
\hline I & 6 & I2 & 2 & 5 & I & 8 & 418 & 9I! & $23 \cdot 8$ & $453\}$ & 7099 \\
\hline 72 & I52 & 318 & 306 & 248 & 304 & 326 & 4920 & $1220\}$ & 23.0 & $6646\}$ & 7099 \\
\hline I48 & 298 & 466 & 350 & 308 & 270 & 512 & 2875 & 2679 & $23 \cdot I$ & & 5227 \\
\hline 7 & 52 & 27 & 46 & 22 & I4 & 5 & 532 & $920\}$ & $24 \cdot I$ & $705\}$ & 4338 \\
\hline 200 & I90 & 322 & 278 & I34 & 93 & I06 & 2310 & I354 & 241 & 36331 & $433^{\circ}$ \\
\hline 9 & 33 & $\mathrm{I} 4$ & 24 & 24 & I7 & $3^{8}$ & 555 & $437\}$ & $2 \mathrm{I} \cdot 8$ & 7I4 & 3220 \\
\hline I & I & 3 & 6 & 3 & 20 & 102 & 2370 & 271 & & $2506\}$ & \\
\hline II 3 & 288 & 330 & 286 & 244 & 222 & 196 & 1952 & 2924 & 20.9 & & 3631 \\
\hline
\end{tabular}




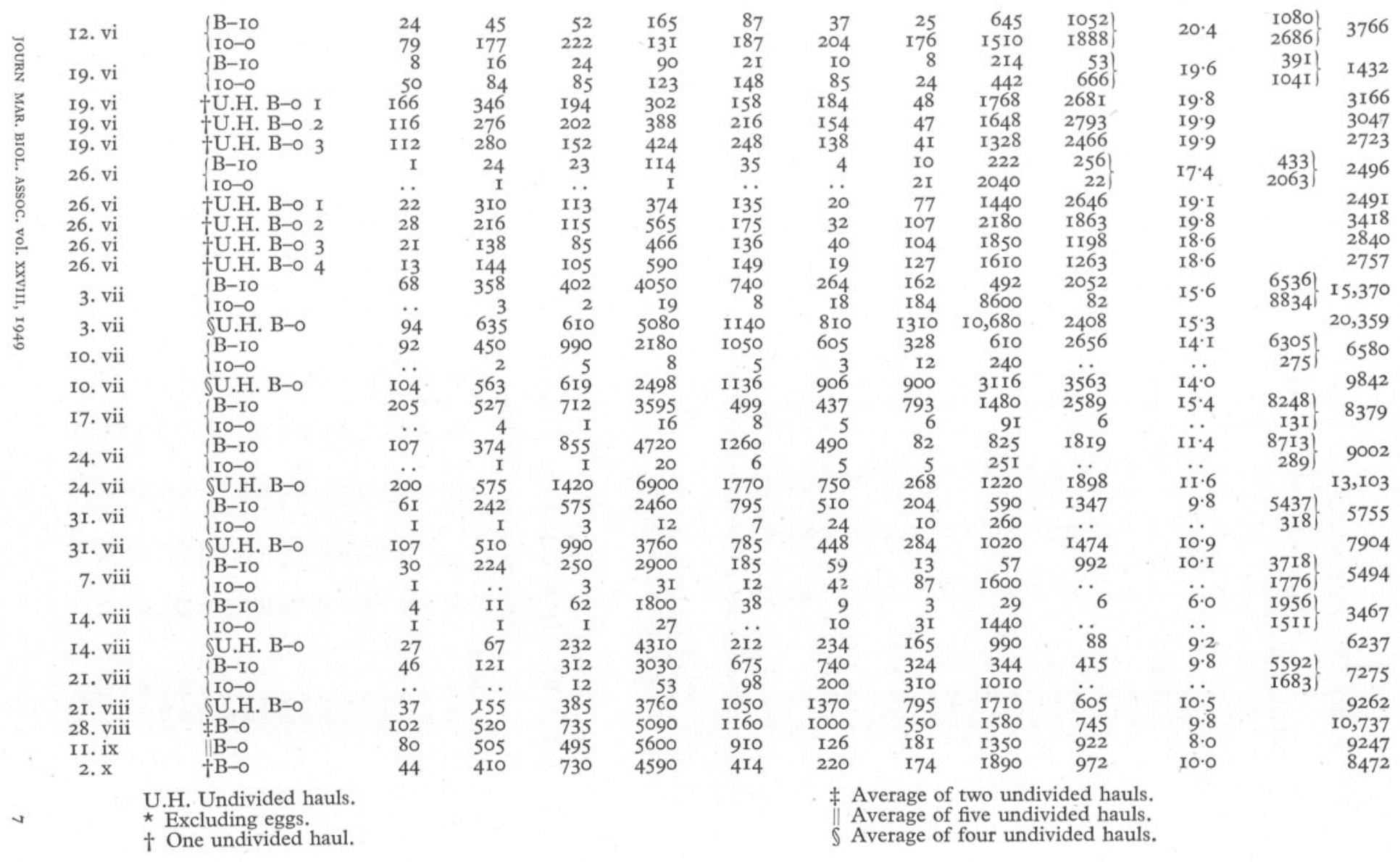


TABle IV. ParacalanUS PARVUS. Number Per haUl

Haul, depth (For meaning of symbols see end of table)

\begin{tabular}{|c|c|c|c|c|c|c|c|c|c|c|c|}
\hline Date & in $\mathrm{m}$. & o & 우 & V & IV & III & II & I & $\mathrm{N}$ & & tal \\
\hline 3. vii & B-O & . & . & .. & 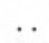 & .. & .. & .. & 1362 & & I362 \\
\hline IO. vii & B-IO & .. & .. & .. & I & .. & .. & & & & \\
\hline & (10-0 & .. & . & .. & .. & . & .. & 3 & $90^{\star}$ & & 94 \\
\hline IO. vii & U.H. B-o & \multicolumn{10}{|c|}{ Not counted } \\
\hline I7. vii & (B-10 & .. & . & I & 2 & 6 & 2 & I) & & & \\
\hline 17. vir & I ro-o & .. & .. & I & I & 3 & 6 & I4) & $169^{\star}$ & & 200 \\
\hline 24. vii & B-10 & .. & 5 & I & 3 & . & . & 7 & & & \\
\hline & Io-o & . & 2 & I & I & 9 & 7 & 38 & $34^{\star}$ & & 423 \\
\hline 24. vii & U.H. B-o & I & I8 & 20 & 5 & I5 & Io & 3 & & & \\
\hline 3I. vii & B-IO & 2 & 8 & I4 & 26 & 20 & 5 & . & & & \\
\hline $3+$. & IO-O & I & I & 7 & 9 & I4 & 23 & 79 & $245^{\star}$ & & 480 \\
\hline 31. vii & U.H. B-o & 2 & 13 & 38 & 72 & 57 & 28 & 58 & & & \\
\hline 7. viii & $\{$ B-IO & $\because$ & 9 & 6 & . & . & I & I & I59* & & 289 \\
\hline & $\begin{array}{l}10-0 \\
\text { (B-IO }\end{array}$ & I & I & 9 & I5 & 44 & 24 & I9 & & & \\
\hline I4. viii & $\left\{\begin{array}{l}D-10 \\
10-0\end{array}\right.$ & .. & $\begin{array}{l}2 \\
I\end{array}$ & $\begin{array}{l}2 \\
2\end{array}$ & $\ddot{5}$ & $\ddot{22}$ & $\ddot{70}$ & $\begin{array}{r}8 \\
68\end{array}$ & $679^{\star}$ & & 892 \\
\hline I4. viii & U.H. B-o & 2 & $2 \mathrm{I}$ & 15 & 3 & 8 & 29 & 64 & & & 092 \\
\hline 2I, viii & B-10 & 2 & II & 43 & 53 & 28 & 7 & 4 & I 48 & $296\}$ & \\
\hline & IO-O & 6 & 5 & 20 & II 8 & I8I & 92 & 38 & 525 & 979) & 1275 \\
\hline 2I. viii & U.H. B-O & 6 & 40 & I 20 & 205 & 205 & 85 & 105 & 650 & & I416 \\
\hline 28. viii & ‡B-O & 40 & 240 & 196 & 170 & I54 & 212 & 304 & I750 & & 3066 \\
\hline II. ix & $\mathrm{B}-\mathrm{O}$ & I8 & 100 & 192 & 308 & 234 & 202 & I 28 & 450 & & 1632 \\
\hline 2. $x$ & $\dagger \mathrm{B}-\mathrm{O}$ & II & 72 & 315 & 575 & 390 & 272 & 212 & 405 & & 2252 \\
\hline
\end{tabular}

* The nauplii were picked out after the hauls had been mixed and the figure is therefore an average only.

$\dagger$ One undivided haul.

$¥$ Average of two undivided hauls.

$\$$ Average of five undivided hauls.

TABle V. MicrocalanUs PygmaEUS. NUMBer Per haul

(For meaning of symbols see end of table)

\begin{tabular}{|c|c|c|c|c|c|c|c|c|c|c|c|}
\hline Date & $\begin{array}{l}\text { Haul, depth } \\
\text { in } \mathrm{m} \text {. }\end{array}$ & ot & q & V & IV & III & II & I & $\mathrm{N}$ & \multicolumn{2}{|c|}{ Total } \\
\hline 7. i & $\S \mathrm{B}-\mathrm{O}$ & I & 7 & 7 & I6 & I6 & 22 & I6 & I80 & & 265 \\
\hline 23. iii & $\$ \mathrm{~B}-\mathrm{O}$ & 4 & I4 & 35 & 25 & 7 & 9 & 23 & 322 & & 439 \\
\hline 30. iii & $\mathrm{B}-\mathrm{O}$ & I & 5 & 8 & 7 & 5 & $2 \mathrm{I}$ & 40 & 136 & & 223 \\
\hline 6. ii & $\$ \mathrm{~B}-\mathrm{O}$ & 6 & $4 \mathrm{I}$ & 54 & I7 & I4 & I7 & 44 & I53 & & \\
\hline 13. ii & $\S \mathrm{B}-\mathrm{O}$ & 8 & 30 & 37 & 35 & $7 \mathrm{I}$ & 85 & $6 \mathrm{I}$ & 209 & & 53 \\
\hline 20. ii & $\S \mathrm{B}-\mathrm{O}$ & 23 & 40 & 70 & II 8 & 129 & 125 & 96 & 324 & & \\
\hline 27. ii & $\$ B-0$ & 3 & 45 & 82 & 58 & 67 & 66 & 38 & 495 & & 85 \\
\hline 7. iii & $\mathrm{B}-\mathrm{O}$ & 50 & I39 & 109 & 43 & II & Io & 6 & 488 & & \\
\hline I3. iii & $\S \mathrm{B}-\mathrm{O}$ & 59 & $9 \mathrm{I}$ & II 6 & 42 & IO & 4 & 25 & $44 \mathrm{I}$ & & 78 \\
\hline 20. iii & $\ddagger \mathrm{B}-\mathrm{O}$ & 78 & 135 & 94 & 7 & 6 & 24 & 30 & 1058 & & I 432 \\
\hline & (B-IO & 9 & 8 & 6 & I & 4 & 7 & 94 & I894 & 2023! & \\
\hline 27. 111 & $\left\{\begin{array}{l}\text { ro-o } \\
\text { r }\end{array}\right.$ & I & 24 & 5 & II & 63 & $4 \mathrm{I}$ & 125 & 572 & 842 & 286 \\
\hline iv & B-10 & 45 & 73 & 22 & 23 & 28 & 60 & 210 & 3621 & 4082 & \\
\hline 4.10 & iro-o & & 4 & I8 & 34 & III & I40 & I52 & 906 & I365 & 5447 \\
\hline I0 iv & (B-IO & 33 & $5 \mathrm{I}$ & $3 I$ & 32 & 59 & 85 & I47 & $345 \mathrm{I}$ & 3889 & 406 \\
\hline $10.1 \mathrm{~V}$ & I0-0 & & 3 & I & 4 & 3 & I & I & I59 & I 72$\}$ & \\
\hline I7, iv & (B-IO & $2 \mathrm{I}$ & 83 & 73 & 56 & 76 & $9 \mathrm{I}$ & IOI & 5712 & 6213 & \\
\hline $17.1 \mathrm{~V}$ & \{10-0 & I & 3 & 4 & 3 & 7 & 6 & 9 & I 59 & $192\}$ & 40 \\
\hline
\end{tabular}


TABLE V (cont.)

\begin{tabular}{|c|c|c|c|c|c|c|c|c|c|c|c|}
\hline Date & $\begin{array}{l}\text { Haul, depth } \\
\text { in } \mathrm{m} \text {. }\end{array}$ & 0 & 우 & V & IV & III & II & I & $\mathrm{N}$ & \multicolumn{2}{|c|}{ Total } \\
\hline 1 & B-ro & I3 & $8 \mathrm{I}$ & 33 & 56 & 80 & I I I & I5O & 292 & 8 I6 & \\
\hline 11 & Io-0 & J & I & I & 2 & 5 & .2 & 2 & 6 & I9) & 835 \\
\hline 24. iv & ‡U.H. B-o & 85 & 517 & 308 & 338 & 304 & 379 & 366 & 544 & & $284 \mathrm{I}$ \\
\hline I. $\mathrm{V}$ & B-IO & 4I & 292 & 384 & 294 & 302 & 183 & 95 & 36 & 2227\} & \\
\hline 1. V & $110-0$ & $\cdots$ & . & I & $\ldots$ & I & . & . & 4 & & 2233 \\
\hline 8. v & B-IO & I6 & 105 & IO4 & 47 & I9 & 8 & 9 & 876 & I I84! & II 89 \\
\hline 8. v & $\begin{array}{l}\text { IOO-O } \\
\pm U . H . B-0\end{array}$ & $\ddot{48}$ & 2 & I & $\therefore$ & I & $\ddot{0}$ & $\because$ & I & 5) & 1109 \\
\hline I5. V & $+\mathrm{B}-\mathrm{O}$ & $\begin{array}{r}48 \\
186\end{array}$ & $\begin{array}{l}685 \\
305\end{array}$ & 545 & I93 & 72 & I8 & 22 & I76 & & 1759 \\
\hline 22. V & B-IO & 47 & $\begin{array}{l}305 \\
238\end{array}$ & $\begin{array}{l}410 \\
\text { I49 }\end{array}$ & $\begin{array}{r}52 \\
10\end{array}$ & 32 & I2 & 24 & 772 & & I893 \\
\hline $22 . V$ & Io-O & $\ldots$ & 5 & $\begin{array}{r}49 \\
2\end{array}$ & $\begin{array}{l}19 \\
\cdots\end{array}$ & $\begin{array}{l}5 \\
I\end{array}$ & $\begin{array}{l}6 \\
I\end{array}$ & $\begin{array}{r}3 I \\
I\end{array}$ & $\begin{array}{r}3933 \\
26\end{array}$ & $\begin{array}{r}4428 \\
36\end{array}$ & 4464 \\
\hline 22. V & ‡U.H. B-o & I06 & 505 & 336 & 29 & 26 & 35 & 70 & 2538 & & 3645 \\
\hline 29. V & B-ro & 53 & 264 & 57 & I5 & 5 & 25 & 102 & 3523 & 4044! & $4 \mathrm{I}$ \\
\hline & $1 \mathrm{IO}-0$ & $\begin{array}{r}\mathrm{I} \\
8\end{array}$ & 7 & $\ddot{0}$ & $\ddot{0}$ & 3 & I & 3 & 90 & I05 & 412 \\
\hline 5. vi & $\left\{\begin{array}{l}\mathrm{B}-\mathrm{IO} \\
\mathrm{IO}-\mathrm{O}\end{array}\right.$ & I8 & $\begin{array}{r}\text { II } 2 \\
4\end{array}$ & IO & I2 & $\mathrm{I}_{3}$ & 34 & 35 & $\begin{array}{r}2920 \\
8 I\end{array}$ & $3154\}$ & 3243 \\
\hline 5. vi & 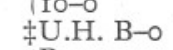 & 43 & 464 & 26 & İ & 29 & 46 & 89 & $\begin{array}{r}01 \\
1957\end{array}$ & & 2670 \\
\hline I2. vi & B-IO & 6 & 585 & 34 & 35 & 64 & 69 & 79 & 8870 & 9742 ? & \\
\hline & iro-o & $\cdots$ & 8 & 2 & I & 2 & 2 & 3 & 386 & 404 & \\
\hline I9. vi & B-IO & I & I05 & IO & I4 & 4 & 5 & II & I080 & $1230\}$ & I409 \\
\hline I9. vi & $\begin{array}{l}\text { Io-0 } \\
\star \text { U.H. B-o }\end{array}$ & $\therefore$ & $\ddot{240}$ & $\ddot{22}$ & $\ddot{26}$ & $\ddot{2}$ & $\ddot{20}$ & $\ddot{18}$ & $\begin{array}{r}179 \\
1600\end{array}$ & I79) & \\
\hline 19. vi & $\star$ U.H. B-o & 3 & 344 & 35 & $3 I$ & 8 & I2 & 19 & 1064 & & $\begin{array}{l}1947 \\
1516\end{array}$ \\
\hline I9. vi & *U.H. B-o & 3 & I58 & 20 & I5 & I3 & 7 & II & I86 & & $\begin{array}{l}\text { I5 I6 } \\
\text { IO43 }\end{array}$ \\
\hline 26. vi & B-IO & 7 & I32 & I4 & I6 & 23 & 22 & 59 & 7240 & $7513 !$ & 1043 \\
\hline 20. V1 & Io-0 & $\cdots$ & $\cdots$ & . & . & $\cdots$ & . & $\therefore$ & 74 & 74 & $75^{8}$ \\
\hline 26. vi & ${ }^{\star}$ U.H. B-o & I5 & 520 & 9I & 78 & 26 & 25 & 67 & I750 & & 2572 \\
\hline 26. vi & *U.H. B-o & I4 & $35^{8}$ & $8 \mathrm{I}$ & 56 & 43 & 35 & 95 & 4740 & & 5422 \\
\hline 26. vi & *U.H. B-O & I5 & 384 & 79 & 55 & 33 & $2 I$ & 92 & 4950 & & 5629 \\
\hline 26. vi & ${ }^{\star}$ U.H. B-o & I6 & 334 & 76 & 56 & 25 & 25 & 77 & 5670 & & 6279 \\
\hline 3. vii & B-ro & 39 & 1060 & 224 & 83 & $7 \mathrm{I}$ & 82 & 69 & 4265 & $5893 !$. & 5935 \\
\hline 3. vii & $\begin{aligned} & 10-0 \\
+ & \text { UH B B-O }\end{aligned}$ & $\ddot{0}$ & $228^{2}$ & $\ddot{8}$ & $\ddot{0}$ & $\ldots$ & $\because 0$ & $\cdots$ & 40 & 421 & \\
\hline IO vii & $\begin{array}{l}\neq \mathrm{U} . \mathrm{H} . \mathrm{B}-\mathrm{O} \\
\text { (B-IO }\end{array}$ & $\begin{array}{l}90 \\
45\end{array}$ & $\begin{array}{c}2280 \\
600\end{array}$ & 386 & I90 & I30 & 258 & 352 & 7402 & & I I,088 \\
\hline IO. V11 & $\left\{\begin{array}{l}\mathrm{B}-\mathrm{IO} \\
\mathrm{IO}-\mathrm{O}\end{array}\right.$ & $\begin{array}{l}45 \\
\ldots\end{array}$ & 090 & $\begin{array}{r}144 \\
\ldots\end{array}$ & $\begin{array}{r}122 \\
I\end{array}$ & 128 & 80 & $\begin{array}{r}37 \\
I\end{array}$ & $\begin{array}{r}753 \\
16\end{array}$ & $\begin{array}{r}\text { I999 } \\
\text { I8 }\end{array}$ & 2017 \\
\hline Io. vii & $\ddagger$ U.H. B-o & 46 & 968 & 225 & I5I & I80 & I65 & I06 & II 22 & & 2963 \\
\hline I7. vii & B-IO & 39 & II 20 & I90 & I22 & 62 & 39 & I5 & 937 & 2524! & \\
\hline & 1 $10-0$ & I & I & I & . & I & .. & $\cdots$ & I8 & 22 & 2540 \\
\hline 24. vii & B-IO & I2 & 625 & I4I & 37 & I2 & II & II & 553 & I402) & \\
\hline 24. vii & IU.H. B-o & $\ddot{i}$ & . & & I & & $\because$ & $\because$ & 86 & 871 & \\
\hline 3I. vii & B-IO & $\begin{array}{l}30 \\
13\end{array}$ & $\begin{array}{l}525 \\
268\end{array}$ & $\begin{array}{r}\text { I83 } \\
86\end{array}$ & $\begin{array}{r}105 \\
32\end{array}$ & $\begin{array}{l}28 \\
18\end{array}$ & I5 & I3 & 345 & & I244 \\
\hline & 1 ro-o & .. & & .. & 32 & $\cdots$ & $\begin{array}{l}12 \\
\ldots\end{array}$ & 5 & $\begin{array}{l}\text { I99 } \\
\text { I38 }\end{array}$ & $\begin{array}{l}633 \\
138\end{array}$ & $77 \mathrm{I}$ \\
\hline 3I. vii & ‡U.H. B-o & 9 & 262 & 90 & 28 & $2 \mathrm{I}$ & 9 & I6 & 256 & & \\
\hline 7. viii & B-Io & 3 & 93 & 34 & I2 & IO & 6 & I & 208 & 3671 & \\
\hline & Io-0 & $\cdots$ & $\cdots$ & 2 & $\cdots$ & . & .. & $\therefore$ & 65 & 67 & 434 \\
\hline I4. viii & B-ro & 2 & $3 I$ & 9 & I & . & . & . & I99 & $242\}$ & \\
\hline I4. viii & $\begin{array}{l}\text { IO-O } \\
\text { tUH }\end{array}$ & $\because$ & $\ddot{\sim}$ & $\ddot{m}$ & $\ddot{6}$ & $\because$ & $\cdots$ & $\cdots$ & 382 & 3825 & \\
\hline 2I. viii & B-10 & $\begin{array}{l}7 \\
1\end{array}$ & $\begin{array}{l}75 \\
4 I\end{array}$ & 22 & 0 & 2 & 2 & 2 & 458 & & 574 \\
\hline & & $\ldots$ & . & $\begin{array}{l}4 \\
. .\end{array}$ & $\cdots$ & . & $\cdots$ & $\cdots$ & $\begin{array}{r}256 \\
35\end{array}$ & $\begin{array}{r}304 \\
35\end{array}$ & 339 \\
\hline 2I. viii & $\neq$ U.H. B-O & I & 33 & 4 & $\ldots$ & 2 & I & I & 260 & & 302 \\
\hline 28. viii & tB-O & 3 & 76 & I6 & I6 & 2 & 3 & 3 & 890 & & 1009 \\
\hline II. ix & $\oint B-0$ & . & 30 & 5 & 2 & I & 3 & 2 & 240 & & 283 \\
\hline $2: x$ & ${ }^{\star} \mathrm{B}-\mathrm{O}$ & 4 & 40 & I2 & 9 & 3 & I5 & 8 & 310 & & $40 I$ \\
\hline
\end{tabular}


Table VI. Centropages hamatus. Number Per haul (For meaning of symbols see end of table)

Haul, depth

\begin{tabular}{|c|c|c|c|c|c|c|c|c|c|c|c|}
\hline Date & in $\mathrm{m}$. & ot & 우 & V & IV & III & II & I & $\mathrm{N}$ & Tota & \\
\hline 17. i & $\notin \mathrm{B}-\mathrm{O}$ & $\cdots$ & .. & $\cdots$ & .. & $\cdots$ & $\cdots$ & .. & I5 & & I5 \\
\hline 23. i & $\oplus \mathrm{B}-\mathrm{O}$ & . & $\therefore$ & . & .. & .. & .. & + & 17 & & I7 \\
\hline 30. i & $\ddagger \mathrm{B}-\mathrm{O}$ & .. & .. & + & .. & .. & .. & .. & 8 & & 8 \\
\hline 6. ii & $\neq B-0$ & .. & .. & $\cdots$ & $\cdots$ & $\cdots$ & .. & . & IO & & Io \\
\hline I3. ii & $\pm \mathrm{B}-\mathrm{O}$ & .. & .. & .. & .. & .. & .. & .. & 32 & & 32 \\
\hline 20. ii & $\neq B-0$ & .. & .. & .. & .. & .. & .. & . & 132 & & I32 \\
\hline 27. ii. & $\neq \mathrm{B}-\mathrm{O}$ & . & . & .. & .. & .. & .. & + & 39 & & 39 \\
\hline 7. iii & $\neq \mathrm{B}-\mathrm{O}$ & + & .. & .. & . & + & I & + & 224 & & 225 \\
\hline I3. iii & $\ddagger \mathrm{B}-\mathrm{O}$ & $\cdots$ & $\cdots$ & . & $\cdots$ & $\ldots$ & . & + & 87 & & 87 \\
\hline 20. iii & $\| \mathrm{B}-\mathrm{O}$ & + & + & $\because$ & .. & I & I & 3 & 82 & & 88 \\
\hline \multirow{2}{*}{ 27. iii } & . B-10 & . & .. & I & $\cdots$ & 2 & I & 4 & 36 & 44. & 265 \\
\hline & 1ro-o & 4 & . & I & 2 & I5 & 23 & $3 \mathrm{I}$ & 145 & $22 \mathrm{I}$ & \\
\hline \multirow{2}{*}{ 4. iv } & B-10 & I & I & 2 & I & $\therefore$ & I & 2 & 9 & I7). & 256 \\
\hline & ino-o & 3 & 5 & 48 & $2 \mathrm{I}$ & 20 & 52 & 29 & 61 & 239 & 250 \\
\hline \multirow{2}{*}{ Io. iv } & B-ro & I & I & I & $\ldots$ & .. & I & $\therefore$ & I5 & 19 . & $49 I$ \\
\hline & Io-0 & $3 I$ & $2 \mathrm{I}$ & 22 & 32 & 33 & 33 & 24 & 276 & 472 & 491 \\
\hline \multirow{2}{*}{ I7. iv } & . B-IO & I & $\ldots$ & .. & & 2 & 3 & I & 22 & 29 . & \\
\hline & 1ro-o & 27 & I5 & 35 & 26 & 35 & 57 & I43 & 765 & $\mathrm{IIO}^{\circ}$ & 1132 \\
\hline \multirow{2}{*}{ 24. iv } & $\{$ B-10 & 2 & $\because$ & $\because$ & I & I & I & & 45 & 50 ․ & \\
\hline & I $10-0$ & $2 \mathrm{I}$ & I5 & 20 & 52 & 79 & $5 \mathrm{I}$ & I8 & 435 & $69 I^{\circ}$ & $74 \mathrm{I}$ \\
\hline 24. iv & \|U.H. B-o & I3 & 33 & 13 & 33 & 18 & I8 & IO & 388 & & 526 \\
\hline \multirow{2}{*}{ I. v } & $\{\mathrm{B}-10$ & 35 & I7 & I6 & I4 & I & 4 & . & 188 & 275 . & \\
\hline & Iro-o & I9 & 19 & 35 & I5 & 9 & 24 & 37 & 905 & 1062 & 1337 \\
\hline \multirow{2}{*}{ 8. v } & $\{$ B-IO & $\ldots$ & $\because$ & $\because:$ & I & .. & I & $\therefore$ & 14 & I6! & I278 \\
\hline & 1ro-o & 12 & 3 & I5 & I8 & $3 I$ & 54 & II9 & IOIO & I262 & \\
\hline \multirow{2}{*}{$\begin{array}{r}8 . \mathrm{v} \\
15 . \mathrm{v}\end{array}$} & $\| \mathrm{U} . \mathrm{H} . \mathrm{B}-\mathrm{O}$ & 22 & 8 & I5 & I0 & 9 & I7 & 39 & 201 & & $32 \mathrm{I}$ \\
\hline & †B-O & I7 & IO & II & 34 & 52 & 25 & 8 & II 3 & & 270 \\
\hline 22. v & $\left\{\begin{array}{l}B-10 \\
10-0\end{array}\right.$ & $\begin{array}{r}\text { I } \\
\text { II }\end{array}$ & $\because$ & $\begin{array}{r}I \\
33\end{array}$ & 26 & $\begin{array}{l}\mathrm{I} \\
6\end{array}$ & $\ddot{9}$ & ig & $\begin{array}{r}12 \\
272\end{array}$ & $\left.\begin{array}{r}15 \\
38 \mathrm{I}\end{array}\right\}$ & 396 \\
\hline 22. v & \|U.H. B-o & 20 & 6 & $\begin{array}{l}33 \\
47\end{array}$ & 23 & 9 & 9 & 19 & $\begin{array}{l}272 \\
160\end{array}$ & & 293 \\
\hline \multirow{2}{*}{ 29. v } & B-IO & .. & . & $\therefore$ & . & . & & & 23 & $23\}$ & 388 \\
\hline & 1 ro-o & $\cdots$ & 2 & 2 & 3 & I4 & 26 & 60 & 258 & $365 !$ & \\
\hline 5. vi & B-10 & .. & .. & .. & $\cdots$ & $\cdots$ & .. & $\cdots$ & 302 & 302 . & 5598 \\
\hline 5. vi & $\begin{array}{l}\text { IO-O } \\
\text { U.H. B-o }\end{array}$ & $\ddot{4}$ & $\ddot{5}$ & $\ddot{8}$ & $\begin{array}{r}3 \\
14\end{array}$ & $\begin{array}{r}6 \\
17\end{array}$ & $\begin{array}{r}20 \\
8\end{array}$ & $\begin{array}{r}27 \\
9\end{array}$ & $\begin{array}{l}5240 \\
1824\end{array}$ & $5296 !$ & 1880 \\
\hline \multirow{2}{*}{ 12. vi } & B-IO & $\begin{array}{l}4 \\
3\end{array}$ & .. & .. & $\begin{array}{l}14 \\
. .\end{array}$ & I & 2 & I & $\begin{array}{r}1824 \\
\text { II } 2\end{array}$ & II9! & \\
\hline & 1 ro-o & 33 & IO & II & 6 & Io & 20 & 59 & II 40 & I289 & \\
\hline I9. vi & $\{$ B-10 & 4 & I & I & .. & I & .. & $\cdots$ & I3 & 20 ; & $27 \mathrm{I}$ \\
\hline \multirow{2}{*}{$\begin{array}{l}\text { 19. vi } \\
\text { I9. vi }\end{array}$} & $10-0$ & I2 & 3 & 3 & I & I & I & 2 & 228 & $25 \mathrm{I} /$ & 271 \\
\hline & ${ }^{\star} \mathrm{B}-\mathrm{O}$ & 28 & II & 2 & I & I & I & 2 & I92 & & 238 \\
\hline \multirow{2}{*}{ I9. vi } & $\star B-0$ & 35 & 6 & 5 & 3 & 5 & 6 & 3 & 160 & & 223 \\
\hline & B-o & 46 & I9 & 3 & 6 & 3 & $\begin{array}{l}4 \\
2\end{array}$ & 4 & $\begin{array}{r}106 \\
24\end{array}$ & & I9I \\
\hline \multirow{2}{*}{$\begin{array}{l}\text { 20. v1 } \\
\text { 26. vi }\end{array}$} & $\left\{\begin{array}{l}\text { lo-0 } \\
\text { I0- }\end{array}\right.$ & $\cdots$ & $\because$ & .. & 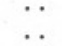 & $\cdots$ & I & I6 & $\begin{array}{r}24 \\
262\end{array}$ & $\begin{array}{r}20 \\
279\end{array}$ & 305 \\
\hline & ${ }^{\star} \mathrm{B}-\mathrm{O}$ & 20 & 2 & 4 & 3 & I & 7 & I2 & 80 & & 129 \\
\hline 26. vi & $\star \mathrm{B}-\mathrm{O}$ & 4 & .. & 5 & 2 & 7 & 8 & 22 & 100 & & I48 \\
\hline 26. vi & $\star \mathrm{B}-\mathrm{O}$ & 2 & .. & .. & I & 4 & 9 & I6 & 123 & & I55 \\
\hline 26. vi & $\star \mathrm{B}-\mathrm{O}$ & 5 & $\because$ & 5 & 2 & 9 & I3 & I5 & I 28 & & I77 \\
\hline 3. vii & B-10 & 4 & 2 & I4 & $\begin{array}{r}28 \\
8\end{array}$ & $\begin{array}{r}8 \\
29\end{array}$ & I & & 6 & 63 . & 419 \\
\hline 3. vii & $\begin{array}{l}\text { IOO-O } \\
\text { U.H. B-B. B }\end{array}$ & $\ddot{13}$ & $\ddot{I}$ & 4 & $\begin{array}{r}8 \\
170\end{array}$ & $\begin{array}{r}29 \\
151\end{array}$ & 45 & 56 & $2 \mathrm{I} 4$ & $356 !$ & \\
\hline & B-10 & 82 & 45 & $\begin{array}{r}45 \\
216\end{array}$ & 74 & 15 & $\begin{array}{r}94 \\
9\end{array}$ & $\begin{array}{r}5 \mathrm{I} \\
6\end{array}$ & II 4 & & 639 \\
\hline IO. vil & lio-o & . & . & I & 5 & I4 & 22 & 70 & 545 & $\begin{array}{l}454 \\
657\end{array}$ & IIII \\
\hline Io. vii & $\|$ U.H. B-o & 79 & 36 & I25 & 64 & 36 & 50 & 105 & 1058 & & I553 \\
\hline I7. vii & B-10 & 48 & 50 & 63 & 74 & 87 & 66 & 34 & 35 & $457\}$ & \\
\hline & 100-0 & I & $\cdots$ & 4 & .. & 6 & 4 & IO & I08 & I33! & 590 \\
\hline 24. vii & B-IO & 64 & 42 & 62 & 42 & 22 & 18 & I & 22 & 273 . & 488 \\
\hline & (10-0 & . & . & .. & .. & .. & I & 5 & 209 & 215 & \\
\hline
\end{tabular}


TABLE VI (cont.)

\begin{tabular}{|c|c|c|c|c|c|c|c|c|c|c|c|}
\hline Date & $\begin{array}{l}\text { Haul, depth } \\
\text { in } \mathrm{m} \text {. }\end{array}$ & ot & 우 & V & IV & III & II & I & $\mathrm{N}$ & Total & \\
\hline 24. vii & |U.H. B-o & 100 & 70 & I35 & 80 & 68 & 48 & 25 & I 88 & & 714 \\
\hline & B-Io & 76 & 46 & 62 & 106 & 189 & II 2 & 33 & 48 & 672 . & \\
\hline 31. VI1 & 1 $10-0$ & I & 4 & 6 & I5 & 24 & 30 & 57 & 625 & 7625 & 1434 \\
\hline 3I. vii & U.H. B-o & 106 & 60 & 93 & 103 & I73 & I 24 & 69 & 535 & & 1263 \\
\hline & B-10 & I3 & 8 & 5 & 3 & 2 & I & $\cdots$ & 4 & 36 . & 236 \\
\hline 7. vil1 & IO & 2 & .. & 2 & I4 & I3 & $3 I$ & 23 & II 5 & $200)^{\prime}$ & \\
\hline & B-10 & I & .. & 2 & . & $\ldots$ & .. & I & 56 & 601 & 669 \\
\hline 14. vin & I Io-o & . & . & $\ddot{a}$ & I & I & I & II & 595 & 609 l' & \\
\hline I4. viii & U.H. B-O & 9 & 6 & $2 \mathrm{I}$ & 26 & I4 & I3 & Io & 475 & & 574 \\
\hline 2I. viii & B-ro & I & 3 & 3 & 6 & 23 & II & 3 & I5 & 65 . & I 57 \\
\hline & Io-0 & I & 5 & 3 & 6 & I5 & I7 & I7 & 28 & $92)$ & 157 \\
\hline 2I, viii & U.H. B-O & 6 & II & 16 & 27 & 54 & 90 & 50 & IIO & & 364 \\
\hline 28. viii & †B-O & I2 & 15 & 98 & 34 & I9 & I8 & I9 & I77 & & 392 \\
\hline II. ix & $\ddagger \mathrm{B}-\mathrm{O}$ & 8 & 6 & 9 & II & 8 & I5 & 32 & 126 & & 215 \\
\hline 2. $x^{\circ}$ & $\star \mathrm{B}-\mathrm{O}$ & $\ldots$ & . & 5 & 9 & 5 & Io & 8 & 108 & & I 45 \\
\hline
\end{tabular}

* One undivided haul.

‡ Average of five undivided hauls.

$\dagger$ Average of two undivided hauls.

Average of four undivided hauls.

+ Present, but less than 0.5 per haul.

TABle VII. TEMORA LONGICORNIS. NUMBer PER HAUl (For meaning of symbols see end of table)

\begin{tabular}{|c|c|c|c|c|c|c|c|c|c|c|c|}
\hline Date & in $\mathrm{m}$. & $\hat{\sigma}$ & 우 & V & IV & III & II & I & $\mathrm{N}$ & \multicolumn{2}{|c|}{ Total } \\
\hline I7. i & $\$ B-0$ & .. & .. & .. & .. & .. & .. & .. & 20 & & 20 \\
\hline 23. i & $\mathrm{B}-\mathrm{O}$ & .. & .. & .. & .. & .. & . & .. & 22 & & 22 \\
\hline 3 I. i & B -0 & .. & .. & .. & .. & . & + & + & I8 & & I9 \\
\hline 7. ii & $\mathrm{B}-\mathrm{O}$ & .. & . & . & .. & + & .. & + & 26 & & 27 \\
\hline I3. ii & $\$ \mathrm{~B}-\mathrm{O}$ & .. & .. & .. & .. & + & . & I & 65 & & 66 \\
\hline 20. ii & $\$ \mathrm{~B}-\mathrm{O}$ & .. & $\cdots$ & .. & .. & + & + & 2 & 122 & & I25 \\
\hline 27. ii & $\$ B-0$ & . & + & .. & I & .. & I & I & 167 & & 171 \\
\hline 7. iii & $\S \mathrm{B}-\mathrm{O}$ & + & + & + & I & 2 & 4 & 9 & 222 & & 238 \\
\hline I3. iii & $\$$ & .. & . & I & I & 4 & 2 & 4 & 74 & & 86 \\
\hline 20. iii & $\ddagger \mathrm{B}-\mathrm{O}$ & .. & I & + & + & I & 4 & 13 & II 7 & & I36 \\
\hline & jB-ro & .. & . & I & I & 3 & I & I & 29 & 36 & 206 \\
\hline 27.111 & I0-0 & 2 & 4 & 2 & 6 & 32 & 9 & I3 & 102 & I70) & 206 \\
\hline 4. iv & (B-10 & .. & 2 & .. & 2 & 2 & 4 & I & 70 & $8 \mathrm{I}$ & \\
\hline & iro-o & 3 & 7 & I & 3 & IO & 9 & I4 & 382 & 429 & 510 \\
\hline Io. iv & (B-IO & & 2 & 2 & & & I & & 135 & I40! & 804 \\
\hline 10.10 & ino-o & 85 & 68 & 45 & 28 & 28 & 22 & 88 & 1390 & I754 & 1894 \\
\hline I7. iv & B-IO & & I & 3 & . & I & 4 & I & 238 & 248 & \\
\hline 17.10 & ino-o & 26 & 27 & 18 & I5 & 27 & 34 & 47 & 2240 & 2434 & 2682 \\
\hline 24. iv & B-IO & 2 & 2 & .. & .. & . & . & .. & 67 & $7 \mathrm{I}$ & 606 \\
\hline 24.10 & i $10-0$ & 9 & Io & II & .17 & 23 & 20 & 50 & 485 & 625 & 090 \\
\hline 24. iv & ‡U.H. B-o & 38 & $\mathrm{I}_{3}$ & I8 & I5 & 8 & Io & 43 & 408 & & 553 \\
\hline I. $\mathrm{v}$ & B-Io & $2 I$ & 6 & I & 3 & 9 & 24 & 16 & I87 & $267\}$ & 1300 \\
\hline & Io-o & 43 & 27 & 35 & $3 I$ & 64 & 138 & 95 & 600 & I033) & \\
\hline $8 . \mathrm{v}$ & B-IO & & & & . & & & & 46 & 46 & 986 \\
\hline 8. $\mathrm{v}$ & $\begin{array}{l}\text { IO-O } \\
\neq \text { U.H. B-o }\end{array}$ & $\begin{array}{l}71 \\
37\end{array}$ & $\begin{array}{l}53 \\
23\end{array}$ & $\begin{array}{l}60 \\
20\end{array}$ & 42 & 26 & 12 & I6 & 660 & 940) & 209 \\
\hline I5. $\mathrm{V}$ & $+\mathrm{B}-\mathrm{O}$ & II & 6 & $\begin{array}{l}29 \\
\text { II }\end{array}$ & $\begin{array}{r}30 \\
3\end{array}$ & $\begin{array}{r}13 \\
1\end{array}$ & $\begin{array}{r}\text { IO } \\
\text { I }\end{array}$ & $\begin{array}{l}\mathrm{I} \\
. .\end{array}$ & $\begin{array}{r}156 \\
88\end{array}$ & & $\begin{array}{l}299 \\
121\end{array}$ \\
\hline 22. v & B-IO & & I & & .. & $\ldots$ & $\ldots$ & & 60 & $6 \mathrm{I}$ & \\
\hline 22.8 & I $10-0$ & 52 & I2 & I4 & I & I & I & 6 & 236 & 323 & 384 \\
\hline 22. $\mathrm{v}$ & ‡U.H. B-० & I5 & I4 & 7 & 5 & I & I & 4 & 140 & & I87 \\
\hline & $\mathrm{B}-\mathrm{IO}$ & I & .. & $\cdots$ & & & .. & & 83 & 84 & \\
\hline $29 . \mathrm{V}$ & I $10-0$ & .. & I & 2 & I & 2 & 2 & I9 & 504 & $53 \mathrm{I}$ & 615 \\
\hline 5. vi & B-IO & .. & $\cdots$ & $\because$ & $\cdots$ & . & $\cdots$ & . & II & II & \\
\hline & Io-0 & $\cdots$ & 2 & 4 & II & 9 & I0 & 27 & 318 & $38 \mathrm{I})$ & 392 \\
\hline
\end{tabular}




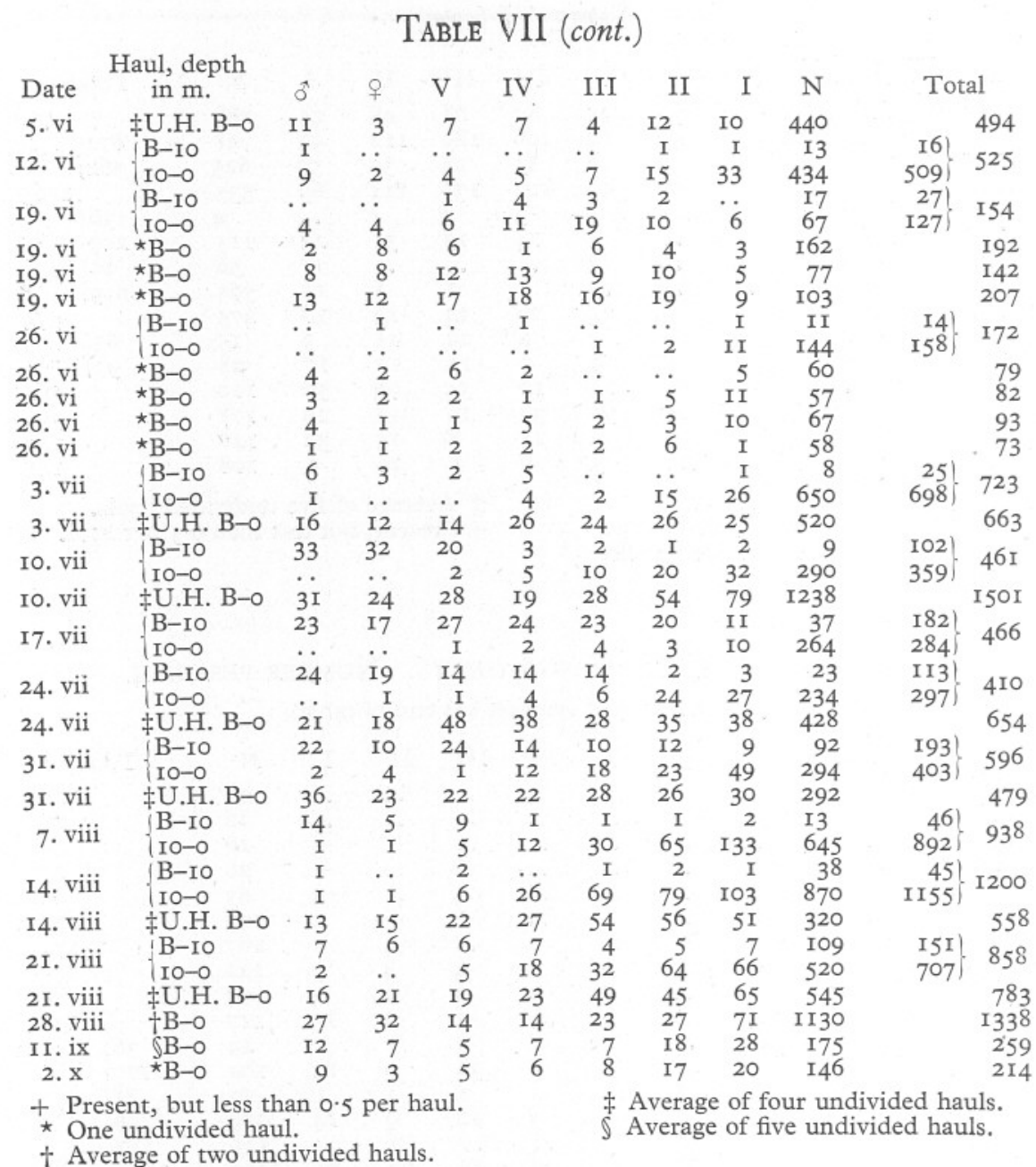

TAble VIII. Acartia ClaUsi. Number Per haul

(For meaning of symbols see end of table)

\begin{tabular}{|c|c|c|c|c|c|c|c|c|c|c|c|}
\hline Date & in $\mathrm{m}$. & $\hat{o}$ & 우 & V & IV & III & II & I & $\mathrm{N}$ & \multicolumn{2}{|l|}{ Total } \\
\hline I7. $\mathrm{i}$ & $\S B-0$ & I & 4 & $\ldots$ & . & + & $\cdots$ & $\cdots$ & 5 & & IO \\
\hline $23 . \mathrm{i}$ & $\$ \mathrm{~B}-\mathrm{O}$ & + & 6 & + & + & . & + & . & 4 & & I I \\
\hline 30. i. & $B-0$ & + & 3 & . & . & . & $\cdots$ & . & 9 & & I 2 \\
\hline $6 . \mathrm{ii}$ & \$B-o & . & 3 & $\ldots$ & . & . & . & . & 16 & & I9 \\
\hline I3. ii & B-o & + & 3 & + & . & + & . & . & 26 & & 29 \\
\hline 20. ii & $\$ B-0$ & . & I & . & $\ldots$ & $\ldots$ & . & I & 32 & & 34 \\
\hline 27. ii & B-O & + & 2 & . & + & + & + & I & I7 & & 22 \\
\hline 7. iii & $\$ B-0$ & + & I & + & + & I & 2 & 2 & 30 & & 37 \\
\hline I3. iii & $\$ B-0$ & .. & I & $\cdots$ & $\ldots$ & $\cdots$ & I & I & 6 & & 9 \\
\hline 20. iii & $\ddagger \mathrm{B}-\mathrm{O}$ & . & I & $\cdots$ & + & I & + & + & 8 & & Io \\
\hline 27. iii & jB-IO & I & .. & .. & .. & $\cdots$ & I & $\ldots$ & II & I3! & \\
\hline & I $10-0$ & .. & . & 2 & . & 2 & 3 & $\cdots$ & I4 & $2 I\}$ & 34 \\
\hline
\end{tabular}


Haul, depth

TABle VIII (cont.)

\begin{tabular}{|c|c|c|c|c|c|c|c|c|c|c|c|}
\hline Date & in $\mathrm{m}$. & $\hat{\sigma}$ & 우 & V & IV & III & II & I & $\mathrm{N}$ & \multicolumn{2}{|l|}{ Total } \\
\hline \multirow{2}{*}{ 4. iv } & B-IO & & & $\cdots$ & $\cdots$ & $\cdots$ & $\cdots$ & .. & 2 & 21 & \multirow{2}{*}{47} \\
\hline & lio-o & 6 & 2 & 3 & $\ldots$ & 4 & 5 & 4 & $2 I$ & $45^{j}$ & \\
\hline \multirow{2}{*}{ Io. iv } & B-IO & . & $\cdots$ & . & . & $\ldots$ & $\ldots$ & $\ldots$ & Io & I0! & \multirow{2}{*}{ IOI } \\
\hline & 1 $10-0$ & 3 & 3 & 5 & I & I & 2 & 5 & $7 \mathrm{I}$ & 9I $\}^{\prime}$ & \\
\hline \multirow[t]{2}{*}{ I7. iv } & B-io & .. & . & $\cdots$ & $\cdots$ & $\cdots$ & I & . & 4 & 5 & \multirow{2}{*}{ I 49} \\
\hline & Io-o & I2 & 6 & Io & 3 & 8 & I2 & I7 & 76 & I44) & \\
\hline 24. iv & $\{\mathrm{B}-\mathrm{IO}$ & 2 & $\underline{I}$ & I & $\cdots$ & $\cdots$ & $\cdots$ & $\cdots$ & 8 & I2! & \multirow{2}{*}{172} \\
\hline 24. iv & $\begin{array}{l}\text { IO-O } \\
\pm \text { U.H. B-O }\end{array}$ & 22 & $3 I$ & 15 & 25 & II & I2 & 6 & 38 & I60) & \\
\hline \multirow{2}{*}{ I. $\mathrm{v}$} & B-IO & $\begin{array}{l}5 \\
5\end{array}$ & $\begin{array}{r}20 \\
5\end{array}$ & $\begin{array}{c}8 \\
. .\end{array}$ & $\mathrm{I}_{3}$ & IO & 8 & 5 & 23 & & 92 \\
\hline & Io-0 & 20 & 22 & $\ddot{9}$ & $\ddot{8}$ & $\ddot{4}$ & $\ddot{8}$ & $\begin{array}{l}\text { I } \\
5\end{array}$ & $\begin{array}{l}26 \\
48\end{array}$ & $\begin{array}{r}37 \\
124\end{array}$ & I6I \\
\hline \multirow[t]{2}{*}{ 8. v } & B-ro & . & $\cdots$ & $\cdots$ & . & $\ldots$ & $\ldots$ & I & $2 I$ & 221 & \multirow{2}{*}{205} \\
\hline & iso-o & 25 & I9 & 5 & 2 & 5 & 5 & I5 & 107 & I83) & \\
\hline $8 . \mathrm{v}$ & ‡U.H. B-o & I4 & Io & I & 2 & .. & .. & 3 & $3 I$ & & $6 I$ \\
\hline I5. V & $+\mathrm{B}-\mathrm{O}$ & 7 & II & 2 & I & 2 & 2 & I & 28 & & 54 \\
\hline 22. V & $\left\{\begin{array}{l}\text { B-IO } \\
\text { IO-O }\end{array}\right.$ & $\begin{array}{r}\text { I } \\
26\end{array}$ & $\ddot{13}$ & $\ddot{24}$ & $\ddot{6}$ & $\because$ & $\cdots$ & $\because$ & 274 & $\begin{array}{l}275 \\
315\end{array}$ & 590 \\
\hline 22. v & ‡U.H. B-o & 20 & I 2 & 5 & 6 & I & $\ddot{I}$ & $\begin{array}{l}9 \\
4\end{array}$ & $\begin{array}{l}234 \\
278\end{array}$ & & 327 \\
\hline 29. v & $\{\mathrm{B}-\mathrm{IO}$ & $\cdots$ & . & $\cdots$ & . & $\ldots$ & I & $\cdots$ & 220 & $22 \mathrm{I} !$ & 2866 \\
\hline 29.0 & Io-0 & 6 & I3 & 6 & 3 & I3 & 46 & 98 & 2460 & 2645 f & \\
\hline 5. vi & B-IO & $\cdots$ & $\cdots$ & $\cdots$ & $\cdots$ & 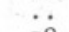 & $\cdots$ & 2 & I68 & I7이 & 2354 \\
\hline 5. vi & $\begin{array}{l}\text { IO-O } \\
\pm \text { U.H. B-o }\end{array}$ & I & 2 & 3 & II & I8 & 53 & 66 & 2030 & $2 \mathrm{I} 84 \sqrt{6}$ & 2354 \\
\hline $5 . \mathrm{V} 1$ & fU.H. B-O & 4 & 7 & Io & I4 & 20 & 23 & 46 & IOI6 & & II 40 \\
\hline I2. vi & $\left\{\begin{array}{l}B-10 \\
I O-O\end{array}\right.$ & $\begin{array}{r}2 \\
22\end{array}$ & 6 & 3 & 4 & 22 & 43 & 48 & I64 & 292 & 3434 \\
\hline & B-IO & $\begin{array}{l}32 \\
\ldots\end{array}$ & $\begin{array}{r}31 \\
3\end{array}$ & $\begin{array}{r}43 \\
2\end{array}$ & 81 & I5 I & 300 & 264 & 2240 & $3142)$ & \\
\hline I9. V1 & Io-0 & 4 & $\begin{array}{r}3 \\
12\end{array}$ & 8 & I5 & $\begin{array}{r}1 \\
33\end{array}$ & I & I & $\begin{array}{r}36 \\
320\end{array}$ & $\left.\begin{array}{r}44 \\
434\end{array}\right\}$ & 478 \\
\hline I9. vi & ${ }^{\star} \mathrm{B}-\mathrm{O}$ & 23 & 22 & 28 & 29 & $\begin{array}{l}33 \\
38\end{array}$ & $\begin{array}{l}23 \\
44\end{array}$ & $\begin{array}{l}19 \\
44\end{array}$ & $\begin{array}{l}320 \\
258\end{array}$ & & 486 \\
\hline I9. vi & ${ }^{\star} \mathrm{B}-\mathrm{O}$ & I9 & 7 & 20 & 26 & $4 \mathrm{I}$ & $\begin{array}{l}44 \\
35\end{array}$ & 30 & 258 & & $\begin{array}{l}400 \\
436\end{array}$ \\
\hline I9. vi & ${ }^{\star} \mathrm{B}-\mathrm{O}$ & 35 & 29 & 45 & 40 & 40 & 48 & 39 & 240 & & $\begin{array}{l}430 \\
516\end{array}$ \\
\hline 26. vi & (B-IO & 2 & 3 & $\cdots$ & $\ldots$ & I & I & 2 & 132 & I4I & \\
\hline & IO-O & 2 & $\ldots$ & $\cdots$ & I & 3 & 2 & 24 & 1040 & 1072 & 1213 \\
\hline 26. vi & ${ }^{\star} \mathrm{B}-\mathrm{O}$ & 9 & I9 & 7 & 9 & Io & IO & $2 \mathrm{I}$ & 525 & & 610 \\
\hline 26. vi & $\star B-0$ & 25 & 34 & 22 & I8 & I3 & I9 & 26 & 555 & & 712 \\
\hline 26. vi & ${ }^{\star} \mathrm{B}-\mathrm{O}$ & $4 \mathrm{I}$ & 32 & 24 & I5 & 22 & I9 & 20 & 830 & & 1003 \\
\hline 26. vi & $\star B-0$ & I3 & I9 & I2 & I 2 & 8 & 22 & I3 & 670 & & 769 \\
\hline 3. vii & (B-IO & 63 & 36 & 36 & I5 & 8 & 4 & I2 & 730 & .904 ! & 6888 \\
\hline $3 . \mathrm{vin}$ & $10-0$ & I & 7 & I & 3 & 64 & 200 & 318 & 5390 & $5984)$ & \\
\hline 3. vii & †U.H. B-o & 222 & I 74 & 99 & 83 & 106 & 210 & $5 \mathrm{IO}$ & 7320 & & 8724 \\
\hline Io. vii & B-10 & 248 & I98 & I52 & I $8 \mathrm{I}$ & 127 & IO2 & 73 & 342 & I 423 & 6382 \\
\hline I0. vii & $\begin{array}{l}\text { IO-O } \\
\pm \text { U.H. B-O }\end{array}$ & $2 \ddot{8} \dot{6}$ & $\begin{array}{r}3 \\
149\end{array}$ & $\begin{array}{r}2 \\
244\end{array}$ & 4 & 22 & I 24 & 264 & $\begin{array}{l}4540 \\
5626\end{array}$ & 4959| & $8 \pi \leq 6$ \\
\hline I7. vii & $\begin{array}{l}\text { TU.H. B-O } \\
\text { B-IO }\end{array}$ & 456 & $25 \mathrm{I}$ & $\begin{array}{l}244 \\
334\end{array}$ & $\begin{array}{l}340 \\
214\end{array}$ & $\begin{array}{l}333 \\
627\end{array}$ & $\begin{array}{l}392 \\
480\end{array}$ & $\begin{array}{l}776 \\
365\end{array}$ & 5636 & & 8156 \\
\hline & $\left\{\begin{array}{l}10-0 \\
\text { 10 }\end{array}\right.$ & 2 & 2 & I & II & 13 & 60 & 187 & $\begin{array}{l}1795 \\
2010\end{array}$ & $\begin{array}{l}4522 \\
2286\end{array}$ & 6808 \\
\hline 24. vii & B-IO & 564 & 490 & 478 & 416 & 402 & 224 & 72 & 520 & 3166 & \\
\hline 24. vii & IOO-O & 3 & 3 & 2 & 4 & 4 & I8 & 54 & I295 & I383 & 4549 \\
\hline $24^{*} \cdot 11$ & $\ddagger U . H . ~ B-0$ & I I IO & I 450 & IO20 & 640 & 720 & 535 & 253 & I430 & & 7158 \\
\hline 3I. vii & $\left\{\begin{array}{l}\mathrm{B}-\mathrm{IO} \\
\mathrm{IO}-\mathrm{O}\end{array}\right.$ & 485 & 510 & 800 & 590 & 362 & 208 & II 4 & 560 & $3629 !$ & (7) \\
\hline 3I. vii & $\begin{array}{l}\text { IO-O } \\
\neq \mathrm{U} . \mathrm{H} . \mathrm{B}-\mathrm{O}\end{array}$ & IO & I5 & 22 & 40 & 77 & 238 & 298 & I390 & 2090 ] & 719 \\
\hline 7. viii & ; & $\begin{array}{l}750 \\
368\end{array}$ & $\begin{array}{r}\text { II } 30 \\
238\end{array}$ & $\begin{array}{r}1100 \\
162\end{array}$ & $\begin{array}{l}640 \\
120\end{array}$ & $\begin{array}{r}408 \\
46\end{array}$ & $\begin{array}{r}600 \\
12\end{array}$ & $4 \mathrm{I} 5$ & I280 & & 6323 \\
\hline & 10-0 & 3 & I & 5 & I 8 & 87 & 165 & $\begin{array}{r}5 \\
234\end{array}$ & $\begin{array}{l}111 \\
\text { II } 40\end{array}$ & $\begin{array}{l}1062 \\
1653\end{array}$ & 2715 \\
\hline I4. viii & B-IO & 42 & 27 & IO & 3 & Io & . & 2 & I44 & 238 & \\
\hline I4. viii & IO-O & I & & I & 5 & 44 & 92 & I54 & 2410 & 2707 & 2945 \\
\hline $24.82 \pi$ & $\ddagger$ U.H. B-o & 212 & I86 & II 3 & 246 & 232 & 100 & 36 & I350 & & 2475 \\
\hline 2I. V111 & $\left\{\begin{array}{l}\text { B-IO } \\
\text { I0-0 }\end{array}\right.$ & 280 & 262 & $\begin{array}{r}163 \\
\mathrm{I} 8\end{array}$ & $\begin{array}{r}86 \\
-8\end{array}$ & 37 & I8 & II & 212 & 1069 & 2905 \\
\hline 2I. viii & $\ddagger$ U.H. B-o & 565 & $290^{+}$ & 375 & 205 & $\begin{array}{l}254 \\
420\end{array}$ & $\begin{array}{l}302 \\
385\end{array}$ & $\begin{array}{l}77 \\
90\end{array}$ & $\begin{array}{l}1000 \\
1700\end{array}$ & & 4030 \\
\hline 28. viii & $+\mathrm{B}-\mathrm{O}$ & 202 & 242 & 376 & 294 & I77 & 177 & I98 & I 360 & & 3026 \\
\hline II. ix & $\S B-0$ & I 52 & 478 & I7 I & I 24 & I 12 & 79 & I 23 & I370 & & 2609 \\
\hline 2. $x$ & ${ }^{\star} \mathrm{B}-\mathrm{O}$ & II 4 & 324 & 296 & 480 & 500 & 565 & 264 & I 540 & & 4083 \\
\hline
\end{tabular}


TABle IX. OIthona Similis. NUMber PeR HaUl

Haul, depth

\begin{tabular}{|c|c|}
\hline Date & in $\mathrm{m}$. \\
\hline I7. $\mathrm{i}$ & $\| \mathrm{B}-\mathrm{O}$ \\
\hline $23 . \mathrm{i}$ & B-O \\
\hline $30 . \mathrm{i}$ & $B-0$ \\
\hline 6. ii & $B-0$ \\
\hline I3. $\mathrm{ii}$ & $\mathrm{B}-\mathrm{O}$ \\
\hline 20. ii & $\mathrm{B}-\mathrm{O}$ \\
\hline 27. $\mathrm{iii}$ & B-O \\
\hline 7. iii & $\mathrm{B}-\mathrm{O}$ \\
\hline I3. iii & $\| \mathrm{B}-\mathrm{O}$ \\
\hline 20. iii & $\oint B-0$ \\
\hline & (B-ro \\
\hline 27.111 & IO-O \\
\hline iv & $\int \mathrm{B}-\mathrm{ro}$ \\
\hline $4.1 \mathrm{~V}$ & Io-o \\
\hline IO iv & (B-IO \\
\hline $10.1 \mathrm{~V}$ & tro-o \\
\hline I7. iv & $\{$ B-IO \\
\hline $1 \% .10$ & 1 10-0 \\
\hline 24. iv & $\{\mathrm{B}-\mathrm{IO}$ \\
\hline 24.18 & Io-0 \\
\hline 24. iv & U.H. B-O \\
\hline I. V & $\left\{\begin{array}{l}\mathrm{B}-\mathrm{IO} \\
\mathrm{S}-\mathrm{O}\end{array}\right.$ \\
\hline 8. & B-ro \\
\hline 8. v & I0-0 \\
\hline 8. v & §U.H. B-o \\
\hline I5. V & $\ddagger \mathrm{B}-\mathrm{O}$ \\
\hline 22. v & B-IO \\
\hline 22. V & SU.H. B-o \\
\hline $20 \mathrm{v}$ & (B-IO \\
\hline $29 . V$ & \{10-0 \\
\hline 5. vi & $\{\mathrm{B}-\mathrm{IO}$ \\
\hline 5. vi & IO-O \\
\hline re vi & (B-IO \\
\hline $12 . V 1$ & | \\
\hline
\end{tabular}

(For meaning of symbols see end of table)

\begin{tabular}{|c|c|c|c|c|}
\hline \multirow[b]{2}{*}{$\sigma$} & \multirow[b]{2}{*}{ 우 } & \multicolumn{3}{|c|}{ (For meaning of symbc } \\
\hline & & V & IV & III \\
\hline 2 & I92 & 69 & 37 & 44 \\
\hline 4 & 210 & 64 & 22 & 16 \\
\hline 6 & I 49 & 29 & I7 & I6 \\
\hline 3 & IOO & I4 & IO & I2 \\
\hline 3 & II3 & $3 i$ & 9 & 9 \\
\hline 2 & 152 & 25 & I4 & I2 \\
\hline 6 & 204 & 24 & I4 & 8 \\
\hline 5 & 268 & 25 & I4 & I4 \\
\hline 2 & I 64 & 8 & 8 & Io \\
\hline 4 & 205 & 26 & I4 & I5 \\
\hline .. & 26 & 5 & 2 & I \\
\hline 4 & $2 I$ & 12 & II & II \\
\hline 2 & 60 & 4 & 2 & 5 \\
\hline IO & 72 & $3 \mathrm{I}$ & 28 & 64 \\
\hline 2 & 29 & 3 & 2 & 5 \\
\hline 22 & 55 & 39 & 67 & 62 \\
\hline 4 & 26 & I2 & 2 & 2 \\
\hline 33 & 9I & 130 & 86 & 36 \\
\hline 5 & 32 & 7 & I & 2 \\
\hline 32 & 79 & 79 & 45 & 36 \\
\hline 43 & I73 & 75 & 33 & 30 \\
\hline 24 & I4I & 62 & 63 & 89 \\
\hline 48 & 52 & 63 & 82 & I 44 \\
\hline I & 5 & I & I & I \\
\hline 36 & 66 & I 44 & 258 & 236 \\
\hline 29 & 135 & 89 & 128 & 127 \\
\hline I3 & 160 & 94 & 84 & 78 \\
\hline$\ldots$ & 4 & 2 & I & I \\
\hline 4 & 85 & 67 & 42 & 55 \\
\hline I3 & 165 & 100 & 69 & 71 \\
\hline 2 & 47 & 9 & 6 & 3 \\
\hline 36 & I44 & I75 & I4I & 202 \\
\hline 8 & 34 & 7 & Io & IO \\
\hline . & II & $2 \mathrm{I}$ & 29 & 50 \\
\hline 44 & 196 & I96 & IOI & $9 \mathrm{I}$ \\
\hline I9 & $6 I$ & 25 & I3 & I4 \\
\hline 20 & 94 & 82 & 65 & 58 \\
\hline
\end{tabular}

No. eggs

per sac

\begin{tabular}{|c|c|}
\hline 5.9 & \\
\hline 5.6 & \\
\hline $6 \cdot 1$ & \\
\hline $6 \cdot 7$ & \\
\hline $7 \cdot \mathbf{I}$ & \\
\hline $\begin{array}{l}8 \cdot 3 \\
8 \cdot 8\end{array}$ & \\
\hline $\begin{array}{l}0.0 \\
9.1\end{array}$ & \\
\hline 9.4 & \\
\hline II 8 & \\
\hline I3. I & $\left.\begin{array}{l}278 \\
6 I 5\end{array}\right\}$ \\
\hline & 202 \\
\hline 14.6 & 827 \\
\hline 14.0 & $\begin{array}{l}286 \\
625\end{array}$ \\
\hline I6.8 & 310 \\
\hline 16.8 & 1716 \\
\hline I 7.4 & $\begin{array}{r}203 \\
I 464\end{array}$ \\
\hline $17 \cdot 6$ & \\
\hline 13.6 & I 370 \\
\hline & $\begin{array}{r}1949 \\
62\end{array}$ \\
\hline $12 \cdot 2$ & 5028 \\
\hline $12 \cdot 6$ & \\
\hline $9 \cdot 2$ & \\
\hline I0.7 & 204 \\
\hline$I I \cdot I$ & \\
\hline 15.5 & 460 \\
\hline & \\
\hline & 2372 \\
\hline I8. 4 & \\
\hline $17 \cdot 2$ & $\begin{array}{r}34 \mathrm{I} \\
2503\end{array}$ \\
\hline
\end{tabular}




\begin{tabular}{|c|c|c|c|c|c|c|c|c|c|c|c|c|c|}
\hline I9. vi & B-IO & Io & 42 & 34 & 12 & 2 & IO & I0 & 252 & $818 !$ & I5.I & 372 & 830 \\
\hline & Io-0 & 9 & 34 & 19 & I4 & II & IO & 5 & 356 & 550 & 151 & 4581 & 830 \\
\hline I9. vi & †U.H. B-o & 42 & I74 & 70 & 36 & 53 & 40 & $5 \mathrm{I}$ & IO40 & 2872 & $\mathrm{I} 4 \cdot 6$ & & I506 \\
\hline I9. vi & †U.H. B-o & 63 & 304 & 206 & 85 & 56 & 67 & 45 & 960 & 3915 & I $4 \cdot 3$ & & I 786 \\
\hline I9. vi & †U.H. B-O & 38 & 192 & 127 & 56 & $4 \mathrm{I}$ & 36 & 28 & 540 & 3132 & I 4.4 & & 1058 \\
\hline 26. vi & $\left\{\begin{array}{l}\text { B-IO } \\
\text { IO-O }\end{array}\right.$ & $\begin{array}{l}\text { I7 } \\
\text { I0 }\end{array}$ & $\begin{array}{l}23 \\
10\end{array}$ & $\begin{array}{l}6 \\
8\end{array}$ & $\begin{array}{l}3 \\
9\end{array}$ & $\begin{array}{r}4 \\
3 \mathrm{I}\end{array}$ & $\begin{array}{r}3 \\
53\end{array}$ & $\begin{array}{r}\text { IO } \\
\text { I35 }\end{array}$ & $\begin{array}{r}228 \\
2760\end{array}$ & $\left.\begin{array}{r}537 \\
50\end{array}\right\}$ & I3.3 & $\begin{array}{r}294 \\
3016\end{array}$ & 3310 \\
\hline 26. vi & †U.H. B-O & 45 & 88 & 33 & I4 & 18 & 27 & 64 & II6o & I $62 \mathrm{I}$ & I3.8 & & I 449 \\
\hline 26. vi & †U.H. B-O & 34 & I I 4 & $4 \mathrm{I}$ & I 7 & 26 & 50 & 88 & I4IO & 2129 & $13 \cdot 2$ & & 1780 \\
\hline 26. vi & †U.H. B-o & 29 & 107 & 46 & 25 & 12 & 33 & $7 \mathrm{I}$ & 2120 & I990 & I2:8 & & 2443 \\
\hline 26. vi & †U.H. B-o & 36 & 126 & 65 & 23 & I8 & 40 & 79 & I 790 & 2194 & $12 \cdot 9$ & & 2177 \\
\hline 3. vii & $\{\mathrm{B}-\mathrm{IO}$ & 71 & 442 & 216 & 68 & 38 & I4 & 48 & 344 & $7980\}$ & I3.9 & 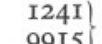 & I I, I56 \\
\hline 3. vii & SU.H. B-o & $\begin{array}{r}10 \\
204\end{array}$ & $\begin{array}{r}37 \\
970\end{array}$ & $\begin{array}{r}53 \\
525\end{array}$ & $\begin{array}{l}129 \\
335\end{array}$ & $\begin{array}{l}326 \\
595\end{array}$ & $\begin{array}{l}420 \\
675\end{array}$ & $\begin{array}{r}780 \\
\times 360\end{array}$ & $\begin{array}{l}8160 \\
9560\end{array}$ & $\begin{array}{c}52\} \\
20,680\end{array}$ & I3.3 & & $I 4,224$ \\
\hline Io. vii & B-IO & IO4 & 690 & 462 & 314 & 195 & 150 & 227 & 725 & I3,550! & & 2867! & 8427 \\
\hline I0. vii & iono & . & 12 & 23 & I4 & 38 & 33 & 120 & 5320 & $24 \int$ & 130 & $5560\}$ & 042 \\
\hline & \$U.H. B-o & I4I & 934 & I I 59 & 827 & 1226 & I789 & 2104 & 9889 & I3,96I & $12 \cdot 3$ & & 18,069 \\
\hline I7. vii & $\left\{\begin{array}{l}\text { B-IO } \\
\text { IO-O }\end{array}\right.$ & $\begin{array}{r}258 \\
\ldots\end{array}$ & $\begin{array}{r}950 \\
2\end{array}$ & $\begin{array}{r}\text { I585 } \\
\text { IO }\end{array}$ & $\begin{array}{r}\text { I } 425 \\
29\end{array}$ & $\begin{array}{r}765 \\
70\end{array}$ & $\begin{array}{l}475 \\
324\end{array}$ & $\begin{array}{l}603 \\
780\end{array}$ & $\begin{array}{l}2080 \\
5910\end{array}$ & $\left.\begin{array}{r}13,650 \\
12\end{array}\right\}$ & $\mathrm{I} 4 \cdot 2$ & 8142. & 15,267 \\
\hline 24. vii & (B-IO & 208 & 920 & 830 & 700 & 400 & $\begin{array}{l}324 \\
414\end{array}$ & I7I & $\begin{array}{r}5910 \\
915\end{array}$ & 12,130 & & $\begin{array}{l}71251 \\
4558\end{array}$ & \\
\hline 24. VII & Io-0 & I & IO & 65 & I69 & 419 & 640 & 404 & 3820 & $59\}$ & $10 \cdot 7$ & $5528\}$ & I0,086 \\
\hline 24. vii & §U.H. B-o & 310 & IOIO & I 520 & I5IO & 1790 & 1800 & IOIO & 4740 & I I,990 & $10 \cdot 6$ & & I3,690 \\
\hline 3I. vii & $\left\{\begin{array}{l}B-10 \\
0-0\end{array}\right.$ & 480 & 990 & I300 & 535 & 340 & 368 & 220 & 2510 & I2,790) & 9.9 & 6743). & I I ,092 \\
\hline 3I. vii & $\begin{array}{l}\text { IOO-O } \\
\text { SU.H. B-o }\end{array}$ & $\begin{array}{r}26 \\
290\end{array}$ & $\begin{array}{r}61 \\
\text { II } 90\end{array}$ & $\begin{array}{r}295 \\
1590\end{array}$ & $\begin{array}{r}273 \\
1030\end{array}$ & $\begin{array}{l}356 \\
770\end{array}$ & $\begin{array}{l}312 \\
740\end{array}$ & $\begin{array}{l}336 \\
670\end{array}$ & $\begin{array}{l}2690 \\
3810\end{array}$ & $\begin{array}{r}\text { IO8) } \\
\text { II } 840\end{array}$ & $9 \cdot 7$ & $4349)^{\prime}$ & I0,090 \\
\hline 7. viii & B-10 & 34 & 438 & 328 & 212 & 69 & 48 & 35 & 515 & 4080 & 97 & I679| & \\
\hline $7.8 \mathrm{Bn}$ & $10-0$ & I7 & 168 & 488 & 730 & 800 & 930 & 1070 & 6130. & 589 & $7 \cdot 6$ & 10,333 & 12,012 \\
\hline I4. viii & B-IO & 4 & 57 & 66 & 29 & 20 & I2 & 23 & 364 & 49I! & $7 \cdot 2$ & 575 & 4682 \\
\hline & IIO-O & I2 & 37 & 256 & 290 & I9I & I93 & 258 & 2870 & $49 /$ & & 4I07 & \\
\hline I4. vi1i & U.H. B-O & $3 I$ & 490 & 545 & 595 & 350 & 224 & 212 & 2450 & 3158 & $7 \cdot 8$ & & 4897 \\
\hline 2I. viii & $\left\{\begin{array}{l}B-10 \\
10-0\end{array}\right.$ & $\begin{array}{l}83 \\
67\end{array}$ & $\begin{array}{l}510 \\
382\end{array}$ & $\begin{array}{l}455 \\
627\end{array}$ & $\begin{array}{r}505 \\
\text { I1 } 20\end{array}$ & $\begin{array}{r}390 \\
1480\end{array}$ & $\begin{array}{r}360 \\
2150\end{array}$ & $\begin{array}{r}404 \\
1810\end{array}$ & $\begin{array}{r}4240 \\
\mathrm{II}, \mathrm{I} 20\end{array}$ & $\left.\begin{array}{l}6490 \\
4885\end{array}\right\}$ & $8 \cdot 7$ & $\left.\begin{array}{r}6947 \\
18,756\end{array}\right\}$ & 25,703 \\
\hline 2I. viii & §U.H. B-o & 225 & 1270 & 1430 & 1830 & 2330 & 2360 & I 780 & 15,350 & 13,450 & $8 \cdot 9$ & & 26,575 \\
\hline 28. viii & $\ddagger \mathrm{B}-\mathrm{O}$ & I33 & 1240 & 2000 & 3160 & 3010 & 2260 & I 500 & I8, IOO & 6425 & $7 \cdot 1$ & & 31,403 \\
\hline II, ix & $B \mathrm{~B}-\mathrm{O}$ & 83 & 860 & I470 & I4IO & 575 & 498 & 386 & 5580 & 4760 & $7 \cdot 1$ & & 10,862 \\
\hline $2 . x$ & $\dagger \mathrm{B}-\mathrm{O}$ & 85 & 665 & 620 & 805 & 980 & 1450 & 770 & 3580 & 3940 & $8 \cdot 0$ & & 8958 \\
\hline
\end{tabular}


Table X. Size of PSEUdocalanus minUtus in mM.

\begin{tabular}{|c|c|c|c|c|c|c|c|c|c|c|c|c|c|c|c|c|c|c|c|c|c|}
\hline Stage & Date & No. & $\begin{array}{r}0.487- \\
0.539\end{array}$ & $\begin{array}{c}0.539- \\
0.592\end{array}$ & $\begin{array}{r}0.592- \\
0.644\end{array}$ & $\begin{array}{c}0.644- \\
0.696\end{array}$ & $\begin{array}{c}0.696- \\
0.748\end{array}$ & $\begin{array}{r}0.748- \\
0.800\end{array}$ & $\begin{array}{c}0.800- \\
0.853\end{array}$ & $\begin{array}{c}0.853- \\
0.905\end{array}$ & $\begin{array}{c}0.905- \\
0.957\end{array}$ & $\begin{array}{r}0.957- \\
1.009\end{array}$ & $\begin{array}{c}1.009- \\
1.061\end{array}$ & $\begin{array}{l}\mathrm{I} \cdot 06 \mathrm{I}- \\
\mathrm{I}^{\prime}+\mathrm{III}_{4}\end{array}$ & $\begin{array}{c}\mathrm{I} \cdot 114- \\
I^{\prime} \cdot 166\end{array}$ & $\begin{array}{r}I \cdot 166- \\
1 \cdot 218\end{array}$ & $\begin{array}{r}\mathrm{I} \cdot 2 \mathrm{218-} \\
\mathrm{I} \cdot 27 \mathrm{O}\end{array}$ & $\begin{array}{r}1 \cdot 270- \\
1 \cdot 322\end{array}$ & $\begin{array}{r}1 \cdot 322- \\
1 \cdot 375\end{array}$ & $\begin{array}{r}1.375- \\
1.427\end{array}$ & $\begin{array}{l}\text { Median } \\
\text { size }\end{array}$ \\
\hline \multirow[t]{21}{*}{$\hat{o}$} & $\begin{array}{l}17 . \mathrm{i} \\
23 . \mathrm{i}\end{array}$ & $\begin{array}{l}6 \\
8\end{array}$ & .: & :. & .: & 2 & $\begin{array}{l}2 \\
2\end{array}$ & ${ }_{\mathrm{I}}^{2}$ & $\ddot{4}$ & $\ddot{i}$ &.. &. &.. &.. &.. &. &.. &.. &.. & .. & .. \\
\hline & $\begin{array}{l}23.1 \\
30 . \mathrm{i}\end{array}$ & 13 & :. & $\because$. & $\because$. & :. & $\begin{array}{l}2 \\
5\end{array}$ & $\begin{array}{l}1 \\
4\end{array}$ &. & $\begin{array}{l}1 \\
3\end{array}$ & $\because$. & $\ddot{I}$ & :. & $\because$. & .. & :. & $\because$. & $\therefore$ & :. & $\because$ & 0.765 \\
\hline & $\begin{array}{l}\text { 6. ii ii } \\
\text { 20. iii }\end{array}$ & $\begin{array}{r}23 \\
9\end{array}$ & :. & $\because$ & :. & : & $\begin{array}{r}10 \\
\text { I }\end{array}$ & $\begin{array}{l}3 \\
2\end{array}$ & $\begin{array}{l}4 \\
2\end{array}$ & $\begin{array}{l}5 \\
3\end{array}$ & $\because$ & $\begin{array}{l}\mathrm{I} \\
\mathrm{I}\end{array}$ & $\because$ & .. & .. & $\because$ & $\therefore$ & : & .: & $\because$ & $\begin{array}{l}0.783 \\
0.852\end{array}$ \\
\hline & 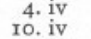 & $\begin{array}{l}19 \\
65\end{array}$ & :. & $\because$. & $\because:$ & :. & $\because:$ & $\ddot{i}$ & $\begin{array}{l}2 \\
5\end{array}$ & $\begin{array}{l}10 \\
19\end{array}$ & $\begin{array}{r}2 \\
23\end{array}$ & $\begin{array}{r}3 \\
13\end{array}$ & $\begin{array}{l}2 \\
4\end{array}$ & $\because$. & : & $\because$. & $\because$. & $\therefore$ & : & : & $\begin{array}{l}0.893 \\
0.915\end{array}$ \\
\hline & 17. iv & $6 \mathrm{I}$ & .. & .. & .. & .. & 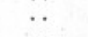 & I & 3 & $\begin{array}{l}18 \\
18\end{array}$ & 13 & $\begin{array}{l}20 \\
27\end{array}$ & 6 & $\because$. & $\because$ & $\because$ & $\because$. & $\because$ & $\because$ & $\because$ & 0.939 \\
\hline & $\begin{array}{l}\text { 24. iv } \\
\text { I. v }\end{array}$ & $\begin{array}{r}98 \\
133\end{array}$ & .. & . & $\because$ & . & :. & $\because$ & ii & 29 & 31 & $\begin{array}{l}27 \\
25\end{array}$ & II & .. & : & .. & $\because$ & $\because$. & . & .. & $\begin{array}{l}0.935 \\
0\end{array}$ \\
\hline & 8. v & $\begin{array}{r}133 \\
99\end{array}$ & $\because \because$ & $\because$ & $\because$ & $\because$ & $\because$ & $\because$ & 26 & 40 & $\begin{array}{l}45 \\
26\end{array}$ & $\begin{array}{r}25 \\
6\end{array}$ & $\begin{array}{l}3 \\
\mathrm{I}\end{array}$ & $\because \because$ & $\because$ & :. & $\because$ & $\because$ & $\cdots$ & . & $\begin{array}{l}0.999 \\
0.882\end{array}$ \\
\hline & $15 . \mathrm{v}$ & 76 & .. & .. & .. & .. & .. & $\mathrm{I}$ & 20 & 38 & 13 & 4 & .. & .. & .. & .. &.. & .. & . & & 0.886 \\
\hline & $\mathrm{v}$ & $\begin{array}{r}119 \\
80\end{array}$ & .. & .. & . & .. & . & 6 & 77 & 28 & & . & .. & .. & . & .. & .. & .. & .. & . & 0.836 \\
\hline & 5. vi & $\begin{array}{l}119 \\
110\end{array}$ & .. & :. & :. & .. & :. & $\begin{array}{l}11 \\
16\end{array}$ & 65 & 27 & $\ddot{2}$ & ... & ... & $\because$. & $\because$. & $\because$. & $\because$. & :. & :. & .: & $\begin{array}{l}\begin{array}{l}0.839 \\
0.830\end{array} \\
0.830\end{array}$ \\
\hline & I2, vi & 97 & .. & .. & .. & $\ddot{i}$ & 2 & 40 & 49 & ${ }_{22}^{6}$ & $\because$ & . & .. & .. & . & .. & .. & . & .. & . & 0.806 \\
\hline & 26. vi & 72 & $\because$ & :. & $\because$ & .. & $\begin{array}{l}1 \\
\text { I }\end{array}$ & 20 & $\begin{array}{l}49 \\
29\end{array}$ & 21 & $\begin{array}{l}3 \\
\mathbf{I}\end{array}$ & $\therefore$ & :. & :. & .. & $\because$. & .. & : & . & & $\begin{array}{l}0.808 \\
0.8337\end{array}$ \\
\hline & 3. vii & 133 & .. & .. & .. & $\because$ & 5 & 35 & 70 & 23 &. & .. & .. & .. & .. & .. & .. & .. & & & 0.826 \\
\hline & IO. vii & 117 & .. & .. & .. & .. & 12 & 40 & 50 & 14 & $\mathrm{I}$ & .. & .. & .. & .. & .. & .. & .. & .. & & 0.809 \\
\hline & 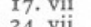 & $\begin{array}{r}99 \\
92\end{array}$ & $\cdot$ & $\cdots$ & 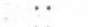 & I & $\begin{array}{l}33 \\
56\end{array}$ & 30 & 25 & 9 & 1 & . & $\cdots$ & $\cdots$ & .. & .. & . & .. & .. & & 0.778 \\
\hline & 3I. vii & $\begin{array}{ll}113 \\
\text { III }\end{array}$ & $\because$ & $\because$ & $\because$ & 33 & 53 & ${ }_{7}^{25}$ & 15 & 3 & $\because$ & $\because$ & $\because \because$ & $\because$ & $\because$ & $\because$ & $\because$ & $\because$ & 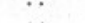 & 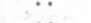 & $0.74 \mathrm{I}$ \\
\hline & 7 . viii & 30 & .. & .. & .. & 15 & 5 & $\therefore$ & 7 & 3 & .. & .. & .. & .. & .. & & .. & . & & & $\begin{array}{l}0.708 \\
0.698\end{array}$ \\
\hline & I4. viiii & 96 & .. & .. & 2 & 52 & 15 & 9 & 13 & 5 & .. & .. & .. & .. & .. & & & .. & .. & & 0.692 \\
\hline & 21. Vili & $\begin{aligned} \\
113\end{aligned}$ & . & . & $\ddot{I}$ & 44 & 46 & I0 & II & 2 & . & $\cdots$ & $\cdots$ & $\cdot$ & $\cdots$ & $\cdots$ & . & . & . & .. & $0 \cdot 705$ \\
\hline & & 78 & $\because$ & $\because$ & I & $\begin{array}{l}31 \\
46\end{array}$ & 23 & 2 & $\ddot{4}$ & 2 & $\because$ & $\because$ & $\because \because$ & $\because \because$ & $\because$ & . & ". & . & $\cdots$ & 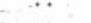 & $\begin{array}{l}0.690 \\
0.602\end{array}$ \\
\hline & $2, x$ & 39 & .. & .. & .. & II & 26 & 2 & 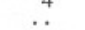 & .. & .. &.. & .. & ... & & $\because$ & ... & .: & $\therefore$ & & $\begin{array}{l}0.713 \\
0.713\end{array}$ \\
\hline \multirow{16}{*}{ 우 } & 17. i & 39 & .. & .. & .. & .. & .. & 2 & 17 & 17 & 3 & .. & .. & .. & .. & .. & .. & & & & \\
\hline & $\begin{array}{l}23 . \mathrm{i} \\
\end{array}$ & $\begin{array}{l}52 \\
38\end{array}$ & .. & . & . & . &. & 2 & 20 & $\begin{array}{l}21 \\
21\end{array}$ & 5 & 4 & $\because$ & . & . & & . & . & .. & .. & 0.862 \\
\hline & 6. ii & $7 \mathrm{I}$ & $\because$. & $\because$ & $\therefore$ & $\therefore$ & $\because$ & .. & $\begin{array}{l}11 \\
18\end{array}$ & 32 & 17 & 4 & .. & $\because$. & $\because$ & $\because$ & $\because$. & ... & ... & $\because$ & $\begin{array}{l}0.874 \\
0.878\end{array}$ \\
\hline & 13. ii & $4 \mathrm{I}$ & .. & .. & . & .. & .. & . & $\begin{array}{r}12 \\
4\end{array}$ & $\begin{array}{l}13 \\
10 \\
10\end{array}$ & $\begin{array}{r}10 \\
8 \\
8\end{array}$ & $\begin{array}{l}5 \\
6\end{array}$ & I & .. & . & .. & .. & .. & .. & .. & 0.880 \\
\hline & & $\begin{array}{l}29 \\
38\end{array}$ & .. & .. & .. & .. & $\because$ & 2 & $\begin{array}{l}4 \\
9\end{array}$ & 0 & 13 & 4 & I & $\because \because$ & $\cdots$ & .: & : & $\because$ & $\because$ & & $\begin{array}{l}0.911 \\
0.901\end{array}$ \\
\hline & 7. iii & 66 & .. & .. & .. & & .. & & 9 & 14 & $2 \mathrm{II}$ & 20 & I & .. & .. & I & .. & & & & $\begin{array}{l}0.926 \\
0\end{array}$ \\
\hline & x3. iiii & 44 & . & . & .. & . & .. & . & 10 & 9 & 16 & 6 & 3 & $\because$ &. & . & .. & & 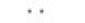 & & 0.915 \\
\hline & $\begin{array}{l}20.111 \\
2\end{array}$ & $\begin{array}{l}57 \\
21\end{array}$ & $\because$ & $\because$ & $\because$ & $\because$ & $\because$ & 1 & 9 & $\begin{array}{l}10 \\
3\end{array}$ & 10 & 15 & 3 & 1 & 2 & . & i & & & & 0.942 \\
\hline & & 50 & $\because$ & $\because$ & $\because$ & $\therefore$ & $\therefore$ & 2 & 2 & 1 & 6 & 2 & 6 & 8 & 14 & II & 3 & 5 & & & $\begin{array}{l}0.957 \\
I .137\end{array}$ \\
\hline & Io iv & 108 & .. &.. & & & .. & & & & 9 & 4 & 3 & 14 & 20 & 25 & 10 & 12 & 7 & I & $\begin{array}{l}1.131 \\
I .168\end{array}$ \\
\hline & & 112 & .. & .. & .. & .. & .. & .. & .. & 3 & 5 & I & 4 & 7 & 35 & 26 & 15 & Ic & 6 & & $\begin{array}{l}1 \cdot 170 \\
I\end{array}$ \\
\hline & 1V & $\begin{array}{l}153 \\
153\end{array}$ & .. & $\cdots$ & & & $\because$ & & 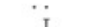 & & $\begin{array}{l}2 \\
2\end{array}$ & 4 & 5 & 21 & $\begin{array}{l}20 \\
20 \\
28\end{array}$ & 29 & 30 & 23 & II & is & I.203 \\
\hline & $8 . \mathrm{y}$ & I27 & $\because$ & $\because$ & $\because$ & $\because$ & $\because$ & . & 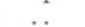 & & $\mathrm{I}$ & 7 & 29 & 46 & 26 & 8 & 3 & 5 & I & & $\begin{array}{l}\text { I.157 } \\
\text { I.097 }\end{array}$ \\
\hline & & 82 & .. & $\therefore$ & . & .. & & . & I & & 3 & 15 & 22 & 19 & 12 & 6 & 3 & I & $\cdots$ & & 1.062 \\
\hline & & 125 & .. & .. & . & & .. & & & & $I$ & 28 & 60 & 19 & 6 & 4 & 3 & 4 & .. & . & I.042 \\
\hline & $\begin{array}{l}29 . v \\
\text { s. vi }\end{array}$ & $\begin{array}{r}99 \\
102\end{array}$ & $\because$. & $\because$ & $\because$ & : & . & : & : & $\begin{array}{l}\text { I } \\
\text { I }\end{array}$ & $\begin{array}{l}\mathrm{I} \\
8\end{array}$ & $\begin{array}{l}23 \\
38\end{array}$ & $\begin{array}{l}4 \mathrm{I} \\
44\end{array}$ & $\begin{array}{r}24 \\
8\end{array}$ & 8 & $\ddot{I}$ & $\begin{array}{l}1 \\
2\end{array}$ & 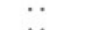 & 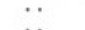 & . & \\
\hline
\end{tabular}




\begin{tabular}{|c|c|c|c|c|c|c|c|c|c|c|c|c|c|c|c|c|c|c|c|c|c|}
\hline Stage & Date & No. & $\begin{array}{c}0.487- \\
0.539\end{array}$ & $\begin{array}{r}0.539- \\
0.592\end{array}$ & $\begin{array}{r}0.592- \\
0.644\end{array}$ & $\begin{array}{c}0.644- \\
0.696\end{array}$ & $\begin{array}{c}0.696- \\
0.748\end{array}$ & $\begin{array}{r}0.748- \\
0.800\end{array}$ & $\begin{array}{c}0.800- \\
0.853\end{array}$ & $\begin{array}{r}0.853- \\
0.905\end{array}$ & $\begin{array}{c}0.905- \\
0.957\end{array}$ & $\begin{array}{c}\text { O.957- } \\
\text { I.009 }\end{array}$ & 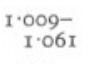 & $\begin{array}{c}\mathrm{I} \cdot 06 \mathrm{~T}- \\
\mathrm{I}+\mathrm{III}\end{array}$ & $\begin{array}{l}\begin{array}{r}1 \\
1\end{array} 14- \\
1 \cdot 166\end{array}$ & $\begin{array}{r}\begin{array}{r}1 \\
1 \\
1\end{array} 6-218- \\
\end{array}$ & $\begin{array}{r}1.218- \\
1.270\end{array}$ & $\begin{array}{r}1.270- \\
1.322\end{array}$ & $\begin{array}{r}\mathbf{1} \cdot 322- \\
1 \cdot 375 \\
-375\end{array}$ & $\begin{array}{r}1 \cdot 375- \\
\quad 1 \cdot 427\end{array}$ & $\begin{array}{c}\text { Median } \\
\text { size }\end{array}$ \\
\hline \multirow[t]{12}{*}{ 우 } & 12. vi & 130 & .. & .. & .. & .. & .. & .. & 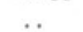 & 4 & 32 & 50 & 37 & 6 & & I &.. & .. & & .. & \\
\hline & & 104 & & .. & & & & & 2 & 6 & 23 & 30 & 28 & I4 & $\mathrm{I}$ &. &.$\cdot$ & .. & .. & .. & 0.999 \\
\hline & $\begin{array}{l}26 . \mathrm{vi} \\
\mathrm{yij}\end{array}$ & $\begin{array}{ll}110 \\
116\end{array}$ & .. & & .. & .. & .. & .. & .. & 3 & $\begin{array}{l}24 \\
20\end{array}$ & 35 & $\begin{array}{l}30 \\
21\end{array}$ & I4 & 3 & ${ }^{1}$ & . & 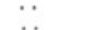 & $\because$. & $\because$ & $\begin{array}{l}0.997 \\
0.970\end{array}$ \\
\hline & $\begin{array}{l}\text { 3. vul } \\
\text { to. vii }\end{array}$ & $\begin{array}{l}116 \\
137\end{array}$ & :. & : & . & : & . & $\ddot{i}$ & $\ddot{3}$ & $\begin{array}{r}9 \\
22\end{array}$ & $\begin{array}{l}39 \\
52\end{array}$ & $\begin{array}{l}34 \\
4 \mathrm{I}\end{array}$ & $\begin{array}{l}21 \\
14\end{array}$ & 3 & ${ }_{1}^{3}$ & $\because$. & $\because$. & $\because$. & :. & $\because$. & $\begin{array}{l}0.970 \\
0.951\end{array}$ \\
\hline & 17. vii & 98 & & .. & .. & .. & . & 1 & 18 & 34 & 23 & 17 & 4 & I & I & $\therefore$ & & $\therefore$ & & .. & $\begin{array}{l}0.901 \\
0.961\end{array}$ \\
\hline & 24. vii & 134 & & .. & $\therefore$ & $\therefore$ & $\ddot{I}$ & 20 & 35 & 31 & 20 & 19 & 5 & 3 & .. & .. & .. & & .. & .. & 0.866 \\
\hline & 3I. vii & 113 & .. & .. & .. &.. & 2 & 22 & 28 & 30 & 20 & 7 & 2 & 2 & $\cdot$. & . & .. & .. & . & & $\begin{array}{l}0.868 \\
0.83\end{array}$ \\
\hline & $\begin{array}{l}7 . \mathrm{vall} \\
\text { IA viii }\end{array}$ & & & & .. & I & 3 & 26 & $\begin{array}{l}31 \\
31 \\
28\end{array}$ & 13 & $\begin{array}{l}18 \\
I^{2}\end{array}$ & 99 & $\begin{array}{l}1 \\
6\end{array}$ & $i$ & $\because$ & $\because$ & $\because$ & $\because$ & ․ & $\because$ & $\begin{array}{l}0.839 \\
0.803\end{array}$ \\
\hline & 2I. viii & $\begin{array}{l}125 \\
127\end{array}$ & .. & .. & . & .. & 7 & ${ }_{43}^{53}$ & $\begin{array}{l}28 \\
28\end{array}$ & 16 & 12 & 6 & 4 & I & :. & $\therefore$ & $\therefore$ & .. & .. & . & 0.806 \\
\hline & 28. viii & 102 & & .. & $\therefore$ & :. & $\begin{array}{r}14 \\
2\end{array}$ & $\begin{array}{l}43 \\
3 \mathrm{I}\end{array}$ & 39 & 14 & 9 & 4 & 3 & . & .. & .. & .. & & . & .. & 0.820 \\
\hline & IIr. ix & $\begin{array}{r}82 \\
167\end{array}$ & .. & . & $\therefore$ & $\therefore$ & 7 & 48 & 19 & 5 & 3 & 7 &.. & .. & .. & .. & & .. & .. & : & $\begin{array}{l}0.784 \\
0.829\end{array}$ \\
\hline & 2. $x$ & & . & .. & .. & .. & 2 & 40 & 77 & 40 & 5 & 2 & I & . & .. & .. & . & . & " & $\ddot{*}$ & $\begin{array}{l}0.829 \\
0.800\end{array}$ \\
\hline \multirow{25}{*}{ 总 } & $\begin{array}{ll}17 . i \\
23, i\end{array}$ & $\begin{array}{l}42 \\
33\end{array}$ & 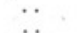 & $\because$. & $\because$. & $\ddot{i}$ & $\begin{array}{l}8 \\
7\end{array}$ & $\begin{array}{l}12 \\
15 \\
15\end{array}$ & $\begin{array}{r}15 \\
4\end{array}$ & $\begin{array}{l}6 \\
3\end{array}$ & $\begin{array}{l}1 \\
3\end{array}$ & $\because$. & $\because$. & :. & 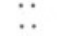 & $\because$. & $\because$. & :. & :. & $\because$ & $\begin{array}{l}8.80 \\
0.765\end{array}$ \\
\hline & 30. i & $\begin{array}{l}35 \\
25\end{array}$ & $\therefore$ & . & .. & $\therefore$ & $\frac{1}{2}$ & 7 & 6 & 10 & $\because$ & .. & .. & $\therefore$ & $\because$. & $\because$ & $\therefore$ & $\therefore$ & 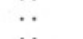 & .. & $0.84 \mathrm{I}$ \\
\hline & 6. $\mathrm{it}$ & ${ }_{8}^{17}$ & . & $\because$. & . & $\because:$ & ${ }_{2}^{4}$ & $\begin{array}{l}4 \\
2\end{array}$ & $\begin{array}{l}2 \\
3\end{array}$ & $\begin{array}{l}5 \\
I\end{array}$ &.$^{2}$ & :. & $\because$. & $\because$. & $\because$ & ... & ... & :. & : & :. & $\begin{array}{l}0.827 \\
0.809\end{array}$ \\
\hline & $\begin{array}{l}27.4 \\
27\end{array}$ & II & .. & :. & .. & .. & I & 2 & 5 & 3 & $\because$ & . & . & $\cdots$ & .. & $\therefore$ & .. & & .. & . & 0.827 \\
\hline & 13. iii & 9 & .. & . & $\cdot$ & .. & .. & I & 2 & 5 & I & . & & .. & . & .. & .. &. & . & & 0.870 \\
\hline & 20 . iii & 18 & .. &. & . & & & 2 & 5 & 8 & 2 & I & $\because \ddot{g}$ & .. & $\cdot$ & .. & $\cdot$ & 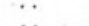 & $\because$ & $\therefore$ & $\begin{array}{l}0.864 \\
0.974\end{array}$ \\
\hline & 4. iv & 45 & . & . & $\cdots$ & .. & . & . & $\because$ & $\begin{array}{r}\text { II } \\
7\end{array}$ & $\begin{array}{r}11 \\
5\end{array}$ & $\begin{array}{l}15 \\
15\end{array}$ & 8 & :. & $\because$ & 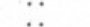 & $\because \because$ & :. & $\because$ & $\therefore$ & $\begin{array}{l}0.974 \\
0.957\end{array}$ \\
\hline & $\begin{array}{l}10.17 \\
\text { iv }\end{array}$ & $\begin{array}{l}23 \\
50\end{array}$ & $\because$ & $\because$ & $\because$ & $\because$ & : & $\because$ & $\ddot{\mathbf{i}}$ & 7 & 9 & 26 & 7 & .. & .. & $\therefore$ & .. & .. & .. & . & 0.975 \\
\hline & 24 iv & $5 \mathrm{I}$ & $\because$ & $\therefore$ & $\therefore$ & $\therefore$ & .. & .. & 2 & 23 & 13 & 9 & 3 & . & I & .. & .. & . & .. & . & 0.914 \\
\hline & $\mathrm{I}, \mathrm{v}$ & 73 & $\therefore$ & $\therefore$ &.. & $\therefore$ & .. & . & 9 & $3 \mathrm{I}$ & 20 & 10 & 2 & I & .. & $\cdot$ & . &. & . & 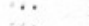 & $\begin{array}{l}\circ .900 \\
0.885\end{array}$ \\
\hline & 8. v & 62 & .. & .. & .. & . & .. & I & I0 & 29 & 21 & I & $i$ & .. & . & 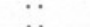 & $\because$ & $\because$ & $\because$ & : & $\begin{array}{l}0.885 \\
0.843\end{array}$ \\
\hline & $15 . \mathrm{v}$ & 65 & . & . & $\cdots$ & *. & $\ddot{I}$ & $\frac{3}{5}$ & $\begin{array}{l}39 \\
50\end{array}$ & $\begin{array}{l}10 \\
26\end{array}$ & $\begin{array}{l}4 \\
4\end{array}$ & I & 1 & :. & .. & $\because \because$ & $\because \because$ & .. & .. & . & $\begin{array}{l}0.43 \\
0.842\end{array}$ \\
\hline & $22 . \mathrm{V}$ & & $\because$ & $\because$ & $\because$ & $\because$ & 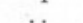 & 3 & 28 & 19 & 2 & 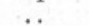 & I & .. & $\therefore$ & .. & .. & $\ldots$ & .. & . & 0.846 \\
\hline & $5, \mathrm{vi}$ & 38 & $\because$ & $\because$ & $\because$ & $\because$ & I & 32 & 25 & 14 & 5 & 2 & .. & I & .. & .. & .. & . & .. & 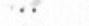 & 0.816 \\
\hline & 12. vi & $9 \mathrm{I}$ &.. &.. & .. & .. & 2 & 44 & 36 & 7 & $\mathrm{I}$ & $\mathrm{I}$ & . & .. & .. & $\cdots$ & $\cdot \cdot$ & $\because$ & $\ddot{*}$ & : & $\begin{array}{l}0.800 \\
0.800\end{array}$ \\
\hline & 19. vị & 103 & .. & .. & .. & .. & 7 & 45 & 22 & 27 & 2 & . & $\cdots$ & $\because$ & $\because$ & : & .. & $\because:$ & $\because:$ & $\therefore$ & $\begin{array}{l}-800 \\
0.856\end{array}$ \\
\hline & 26. $v_{1}$ & 83 & . & $\because$ & $\because$ & $\because$ & 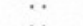 & $\begin{array}{r}12 \\
5\end{array}$ & 30 & 年 & 19 & i & &.. & $\because$ & .. & 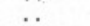 & .. & .. & . & 0.868 \\
\hline & 10. vii & $\begin{array}{r}97 \\
106\end{array}$ & : & $\because$ & $\because$ & ... & $\ddot{8}$ & 38 & 34 & 22 & 4 & &.. & .. &. & .. & .. & .. & . & . & 0.811 \\
\hline & I7. vii & 67 & .. & $\cdots$ & .. & .. & 29 & 14 & 6 & 14 & 3 & I & & .. & . & .. & .. &. & 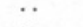 & . & 0757 \\
\hline & 24. vii & 103 & .. & .. & & 8 & 65 & 8 & 6 & Io & 4 & 2 & .. & .. & $\cdots$ & 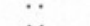 & $\because$ & $\because$ & 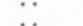 & : & $\begin{array}{l}0.730 \\
0.716\end{array}$ \\
\hline & 3i. vii & 103 & .. & . & . & ${ }_{17}^{17}$ & 62 & 5 & 7 & 10 & $I_{4}^{2}$ & I & & $\therefore$ & $\because$ & $\because \because$ & $\because$ & $\because \because$ & . & : & $\begin{array}{l}1710 \\
0.847\end{array}$ \\
\hline & $\begin{array}{l}\text { 7. vili } \\
\text { is, vili }\end{array}$ & $\begin{array}{l}73 \\
84\end{array}$ & " & . & : & $\begin{array}{r}10 \\
6\end{array}$ & $\begin{array}{l}11 \\
18\end{array}$ & $\begin{array}{l}4 \\
3\end{array}$ & $\begin{array}{l}14 \\
10\end{array}$ & 30 & $\begin{array}{l}14 \\
17\end{array}$ & .. & .. & .. & .. & $\therefore$ & .. &. & . . & . & 0.862 \\
\hline & 2I. viii & 115 & .. & $\therefore$ & $\therefore$ & 23 & 36 & 7 & 19 & 12 & 18 & 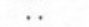 & $\ldots$ & .. & .. & .. & .. & .. & .. & . & 0.740 \\
\hline & 28. viii & 74 & . & .. & .. & 12 & 44 & 3 & 2 & 7 & 5 & 1 & . & . & .. & $\cdots$ & .. & & . & . & $\begin{array}{l}0.7144 \\
0.837\end{array}$ \\
\hline & $\begin{array}{l}\text { III. ix } \\
2, \mathrm{x}\end{array}$ & 58 & . & $\because$ & $\because$ & 7 & $\begin{array}{l}\text { Io } \\
\text { I6 }\end{array}$ & $\begin{array}{l}3 \\
8\end{array}$ & $\begin{array}{l}19 \\
17\end{array}$ & $\begin{array}{l}13 \\
14\end{array}$ & $\begin{array}{l}5 \\
5\end{array}$ & I & .: & $\because$ & : & $\because$. & .. & ... & :. & $\therefore$ & $\begin{array}{l}0.837 \\
0.822\end{array}$ \\
\hline \multirow{5}{*}{$\stackrel{\text { Pे }}{\mathrm{V}}$} & $17 . \mathrm{i}$ & 88 & .. & .. & .. & $\mathbf{I}$ & 18 & 20 & $3 I$ & 18 & & . & . & $\cdots$ & $\cdots$ & $\cdots$ & .. & $\cdots$ & . & .. & 0.808 \\
\hline & $23 . \mathrm{i}$ & 79 & . & .. & .. & $\therefore$ & II & 32 & 22 & II & 3 & .. & .. & .. & .. & . & .. & .. & .. & .. & $\begin{array}{l}0.790 \\
0\end{array}$ \\
\hline & $30 . \mathrm{i}$ & 44 & $\because$ & : & .: & $\ddot{I}$ & 2 & 8 & $\begin{array}{r}22 \\
-8\end{array}$ & 14 & $\ddot{z}$ & $\because$. & $\because$. & :. & .: & :. & $\because$. & $\because$. & ... & :. & $\begin{array}{l}0.836 \\
0.831\end{array}$ \\
\hline & I3. ii & $\begin{array}{r}44 \\
9\end{array}$ & $\therefore$ & $\therefore$ & $\because$ & $\therefore$ & $\vec{I}$ & 2 & 3 & 3 & .. & .. & $\because$. & $\because$ & $\because$ & $\because:$ & $\because$. & $\because$. & $\because$ & $\because$. & $\begin{array}{l}\circ 827 \\
0.822\end{array}$ \\
\hline & 27. ii & 10 &.. & & .. & $\because 4$ & .. & 5 & 3 & $\cdots$ & . & & &. &. & & & & & & \\
\hline
\end{tabular}


TABLE X (contd.)

\begin{tabular}{|c|c|c|c|c|c|c|c|c|c|c|c|c|c|c|c|c|c|c|c|c|c|}
\hline Stage & Date & No. & $\begin{array}{c}0.487- \\
0.539\end{array}$ & $\begin{array}{c}0.539- \\
0.592\end{array}$ & $\begin{array}{c}0.592- \\
0.644\end{array}$ & $\begin{array}{c}0.644- \\
0.696\end{array}$ & $\begin{array}{c}0.696- \\
0.748\end{array}$ & $\begin{array}{r}0.748- \\
0.800\end{array}$ & $\begin{array}{c}0.800- \\
0.853\end{array}$ & $\begin{array}{c}0.853- \\
0.900\end{array}$ & $\begin{array}{c}0.905- \\
0.957\end{array}$ & $\begin{array}{r}0.957- \\
r .009\end{array}$ & 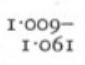 & $\begin{array}{c}\mathrm{I} \cdot 06 \mathrm{I}- \\
\mathrm{I}+\mathrm{II}\end{array}$ & $\begin{array}{c}I^{1}+114- \\
I^{\prime} \cdot 166\end{array}$ & $\begin{array}{c}1 \cdot 166- \\
1 \cdot 218\end{array}$ & $\begin{array}{r}\mathrm{I} \cdot 218- \\
\mathrm{I} \cdot 270\end{array}$ & $\begin{array}{r}I \cdot 270- \\
I \cdot 322\end{array}$ & $\begin{array}{r}\mathrm{I} \cdot 322- \\
1 \cdot 375\end{array}$ & $\begin{array}{r}\mathrm{r} \cdot 375- \\
\mathrm{I} \cdot 427\end{array}$ & $\begin{array}{c}\text { Median } \\
\text { size }\end{array}$ \\
\hline$\stackrel{9}{\mathrm{Y}}$ & 7. iiii & $\begin{array}{l}21 \\
18\end{array}$ & .. &.. &.. &.. & .. & 3 & 13 & 4 &.. & I & .. & &.. &.. &.. &.. &.. &.. & 0.838 \\
\hline & 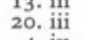 & $\begin{array}{l}18 \\
16\end{array}$ &.. & $\because$. & $\because$. & $\because$. & .. & $\begin{array}{l}3 \\
2\end{array}$ & $\begin{array}{l}6 \\
7\end{array}$ & $\begin{array}{l}5 \\
4\end{array}$ & $\begin{array}{l}3 \\
2\end{array}$ & $\begin{array}{l}\mathrm{I} \\
\mathrm{I}\end{array}$ & $\because:$ & :. & :. & $\because:$ & $\because$. & :. & .. & :. & $\begin{array}{l}0.857 \\
0.850\end{array}$ \\
\hline & $\begin{array}{l}\text { 4. iv } \\
\text { to. in }\end{array}$ & $\begin{array}{l}38 \\
23\end{array}$ & 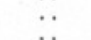 & 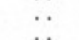 & $\therefore$ & $\because$ & $\because$ &. & $\begin{array}{l}\mathrm{I} \\
2\end{array}$ & $\begin{array}{l}1 \\
1\end{array}$ & 5 & 8 & 7 & I4 & 2 & $\because$ & $\because$. & $\because$. & $\because .$. & $\because$. & $\begin{array}{l}1.053 \\
1.05\end{array}$ \\
\hline & 17. iv & 35 & $\because$ & $\because$. & .. & 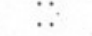 & $\because$ & :. & I & .. & $\begin{array}{l}2 \\
I\end{array}$ & $\begin{array}{l}6 \\
9\end{array}$ & $\begin{array}{r}5 \\
12\end{array}$ & $\begin{array}{r}4 \\
11\end{array}$ & $\begin{array}{l}2 \\
I\end{array}$ & $\because$. & $\because$. & $\because$. & $\because$. & $\because$. & $\begin{array}{l}1.009 \\
1.042\end{array}$ \\
\hline & 24. iv & 55 & . & .. & .. & .. & . & . & .. & 5 & 14 & 20 & 7 & 8 & $\because$ & I & $\therefore$ &.. & .. & .. & $\begin{array}{l}1.4243 \\
0.973\end{array}$ \\
\hline & $\begin{array}{l}\mathrm{I} \cdot \mathrm{v} \\
8 . \mathrm{v}\end{array}$ & $\begin{array}{l}63 \\
60\end{array}$ & $\because$. & $\because$. & $\because:$ & $\because$. & :. & $\because$ & $\because$. & $\begin{array}{l}10 \\
15\end{array}$ & $\begin{array}{l}23 \\
{ }_{35}^{2}\end{array}$ & $\begin{array}{r}21 \\
9\end{array}$ & .6 & .. & ${ }_{1}^{2}$ & $\because$ & $\therefore$ &. & $\because$ & $\because$ & $\begin{array}{l}0.956 \\
0.027\end{array}$ \\
\hline & $\begin{array}{l}15 . \mathrm{v} \\
22 . \mathrm{v}\end{array}$ & $\begin{array}{l}56 \\
8\end{array}$ & .. & .. & .. & .. & .. & .. & 6 & 37 & II & $\therefore$ & 2 & .. &.. & $\therefore$ & .. & .. & $\therefore$ & & $\begin{array}{r}.927 \\
0.881\end{array}$ \\
\hline & $\begin{array}{l}22 . \mathrm{V} \\
29 . \mathrm{T}\end{array}$ & $\begin{array}{l}81 \\
71\end{array}$ & $\because$. & . & . & : & $\because$ & $\ddot{2}$ & $\begin{array}{l}3 \\
8\end{array}$ & $\begin{array}{l}36 \\
42\end{array}$ & $\begin{array}{l}34 \\
\text { I4 }\end{array}$ & ${ }_{3}^{4}$ & 4 & $\ddot{i}$ & $\ddot{i}$ & $\because$ &. & . & .. & . & $\begin{array}{l}0.906 \\
0.882\end{array}$ \\
\hline & 5. vi & 78 & ... & :. & $\because$. & $\because$ & .. & 6 & 32 & ${ }_{32}^{42}$ & $\begin{array}{r}14 \\
4\end{array}$ & $\begin{array}{l}3 \\
3\end{array}$ & $\ddot{I}$ & .. & $\therefore$ & :. & . & & : & $\because$. & $\begin{array}{l}0.882 \\
0.855\end{array}$ \\
\hline & 12. vi & 93 & & .. & .. & .. &. & 9 & 49 & $3 I$ & 3 & $\therefore$ & . & $\ddot{I}$ & $\therefore$ & .. & $\therefore$ & & $\because$. & .. & $\begin{array}{l}0.8555 \\
0.843\end{array}$ \\
\hline & $\begin{array}{l}19 . v 1 \\
26 . \mathrm{vi}\end{array}$ & $\begin{array}{l}95 \\
85\end{array}$ &. & $\because$ & $\because$ & $\because$ & 3 & $\begin{array}{r}25 \\
7\end{array}$ & $\begin{array}{l}36 \\
30\end{array}$ & 27 & 3 & $\because$ & I & $\because$ &.. & $\because$ & .. & .. & .. & $\therefore$ & $\begin{array}{l}0.827 \\
0.827\end{array}$ \\
\hline & 3. vii & 62 & .. & .. & .. & . & 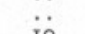 & 2 & 17 & 33 & 8 & $\mathrm{I}$ & $\therefore$ & .. & I & $\therefore$ & .. & .. &.. & $\because$. & $\begin{array}{l}0.862 \\
0.871\end{array}$ \\
\hline & $\begin{array}{l}\text { I. vil } \\
\text { 17. vil }\end{array}$ & $\begin{array}{l}84 \\
62\end{array}$ & $\because$. & :. & :. & $\because$. & $\begin{array}{l}100 \\
13\end{array}$ & $\begin{array}{l}30 \\
12 \\
12\end{array}$ & $\begin{array}{l}29 \\
17\end{array}$ & $\begin{array}{r}9 \\
13\end{array}$ & $\begin{array}{l}6 \\
7\end{array}$ & $\because$ & $\because$ & . & $\because$ & $\because$ & $\because$ & $\because$ & $\because$ & $\because$. & $\begin{array}{l}0.805 \\
0.810\end{array}$ \\
\hline & 24. vii vii & 75 & . & .. & . & $\ddot{i}$ & 32 & 16 & 18 & 8 & I & .. & .. & .. & .. & .. & .. & .. & :. & $\ddot{*}$ & $\begin{array}{r}0.819 \\
0.763\end{array}$ \\
\hline & $\begin{array}{l}\text { 31. vII } \\
\text { 7. viii }\end{array}$ & $\begin{array}{l}90 \\
45\end{array}$ & . & : & $\because$ & $\begin{array}{l}12 \\
12\end{array}$ & $\begin{array}{r}54 \\
8\end{array}$ & $\begin{array}{l}9 \\
2\end{array}$ & 8 & $\begin{array}{l}7 \\
7\end{array}$ & $\ddot{2}$ & $\ddot{i}$ & . &. &. & . & . & .. & .. & . & 0.725 \\
\hline & I4. viii & 75 & .. & .. & .. & 5 & 18 & 3 & 25 & 19 & 5 & .. & $\because$. & .. & .. & $\therefore$ & .. & .. & :. & $\ddot{.}$ & $\begin{array}{l}0.806 \\
0.835\end{array}$ \\
\hline & $\begin{array}{l}21 . \text { vili } \\
28 \text { viii }\end{array}$ & $\begin{array}{r}\text { roI } \\
55\end{array}$ & : & . & $\ddot{I}$ & $\begin{array}{r}22 \\
7\end{array}$ & $\begin{array}{l}27 \\
18\end{array}$ & 10 & II & 23 & 8 &.. &.. & .. &.. & .. &.. &.. & .. & .. & $\begin{array}{l}0.760 \\
\end{array}$ \\
\hline & II. ix & 79 & & .. & .. & 14 & $\begin{array}{l}10 \\
16\end{array}$ & I0 & $\begin{array}{l}18 \\
18\end{array}$ & 16 & 4 & $\because$. & $\ddot{I}$ & ... & .. & ... & :. & & : & :. & $\begin{array}{l}0.755 \\
0.800\end{array}$ \\
\hline & 2. $x$ & 58 & .. & & . & & 14 & 10 & $2 I$ & ro & 3 & $\therefore$ & .. & $\because$. & $\because$. & 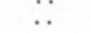 & $\therefore$ & $\because$. & $\because$. & .. & 0.816 \\
\hline IV & $\begin{array}{l}20 \text {. iii } \\
\text { iiv }\end{array}$ & $\begin{array}{l}12 \\
24\end{array}$ & $\because$ & . & . & $\because$ & ${ }_{2}^{2}$ & 5 & 5 & $\ddot{s}$ & . &.. & .. & $\because$ &.. & .. & .. &.. & .. & .. & 0.789 \\
\hline & $\begin{array}{r}47.1 \mathrm{v} \\
7 .\end{array}$ & $\begin{array}{l}24 \\
52\end{array}$ & :. & .. & .. & :. & & $\begin{array}{l}144 \\
20\end{array}$ & $24^{3}$ & 8 & :. & : & $\because$ & $\therefore$ & : & $\because$. & $\because$. &. &. &. & $\begin{array}{l}0.792 \\
0.820\end{array}$ \\
\hline & 24. iv & 57 & & & & & 5 & 34 & 15 & 3 &.. & $\therefore$ & $\therefore$ & $\therefore$ & $\therefore$ & $\because$. & $\therefore$ & $\because$. & $\because$. & $\because$. & $\begin{array}{r}0.820 \\
0.785\end{array}$ \\
\hline & $\begin{array}{l}\text { 1. v } \\
\text { 8. }\end{array}$ & $\begin{array}{l}03 \\
79\end{array}$ & .. & .. & & $\because$. & 20 & $\begin{array}{l}34 \\
39\end{array}$ & $\begin{array}{l}23 \\
19\end{array}$ & $\begin{array}{l}2 \\
\mathrm{I}\end{array}$ & .. & .. & :. & .. & :. & :. & $\because$ & $\because$. & $\because$. & $\because$ & $\begin{array}{r}0.785 \\
0.775\end{array}$ \\
\hline & 15. v & 57 & .. & .. & . & I & 19 & 35 & 2 & 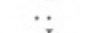 & .. &.. & .. &.. &.. & . & $\therefore$ & $\therefore$ & $\therefore$ & $\because$. & 0.760 \\
\hline & $\begin{array}{l}22 . \mathrm{V} \\
29 . \mathrm{T}\end{array}$ & 49 & .. & $\because$. & . & $\ddot{3}$ & 20 & 23 & 3 & .. & $\because$. & .. & .. &.. & :. & :. & .. & :. & :. & $\because$. & $\begin{array}{l}0.756 \\
07756\end{array}$ \\
\hline & 5. vi & 78 & .. & .. & I & 10 & 23 & $3 \mathrm{I}$ & II & 2 & .. & .. & .. & $\therefore$ & .. & $\because$ & .. &.. & ". & $\because$ & 0.758 \\
\hline & 12. v & 90 & & $\because$ & $\ddot{z}$ & $\begin{array}{l}28 \\
28\end{array}$ & 9 & 47 & 5 & I & .. & .. & $\cdot$ & $\cdot$ & $\cdot$ & . & . &. & & 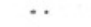 & 0.755 \\
\hline & $26 . \mathrm{vi}$ & 85 & &. & .. & & 8 & 68 & 9 & $\because$ & $\therefore$ & $\because$ & $\because$ & $\because$ & $\because$ & $\because$ & $\because$ & 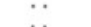 & $\because$ & $\because$ & $\begin{array}{l}0.756 \\
\end{array}$ \\
\hline & 3. vii & 133 & .. & .. & .. & 3 & 24 & 97 & 9 &.. &.. & & $\therefore$ & .. &.. & .. & $\therefore$ & .. & . & $\because$ & $\begin{array}{l}0.775 \\
0.774\end{array}$ \\
\hline & 10. vii & 97 & & .. & .. & II & 9 & 70 & 7 & .. & .. &.. &.. & .. & .. & & .. & .. & . & .. & 0.770 \\
\hline & 17. val & 64 & .. & . & 3 & 3 & 8 & $4 \mathrm{I}$ & 9 &.. & .. & & .. & .. & .. & .. & .. & .. & . & .. & 0.775 \\
\hline & vii & 80 & $\because$ & $\because$ & $\begin{array}{l}\text { II } \\
\text { II }\end{array}$ & 5 & $\begin{array}{c}44 \\
9\end{array}$ & $\begin{array}{l}726 \\
56\end{array}$ & 8 & $\cdots$ & $\because 7$ & $\because$ & $\because$ & * & . & . & $\cdot$ & . & & $\cdots$ & 0.763 \\
\hline & 7. viii & & & .. & $\mathrm{I}$ & $\vec{I}$ & 4 & 39 & 7 & $\therefore$ & & $\therefore$ & $\therefore$ & .. & $\because$ & $\therefore$ & $\because$ & . & & $\because$ & $\begin{array}{l}\circ \cdot 770 \\
0.7776\end{array}$ \\
\hline & I4. viii & 82 & .. & & & I & 10 & 66 & 5 & .. & .. & & .. & & . & .. & .. &. & & $\therefore$ & $\begin{array}{l}0.768 \\
0.768\end{array}$ \\
\hline & 21. vill & 79 &. & .. & 6 & 7 & 12 & 48 & 6 & .. & . & .. & .. & .. & .. & .. & .. & & & & 0.759 \\
\hline & 20 & 82 & $\because$ & & $\begin{aligned} n_{4} \\
{ }_{2}\end{aligned}$ & ${ }^{\circ}$ & 20 & 40 & 4 & $\cdots$ & . & .. & .. & & $\cdots$ & .. & . & . & & & 0.753 \\
\hline & 2. $x$ & 89 & $\therefore$ & .. & 2 & ig & 20 & 46 & $\begin{array}{l}3 \\
2\end{array}$ & .. & .. & :. & $\because$. & :. & : & $\because$. & $\because$. & $\because$ & ․ & $\because$ & $\begin{array}{l}0.762 \\
0.752\end{array}$ \\
\hline
\end{tabular}




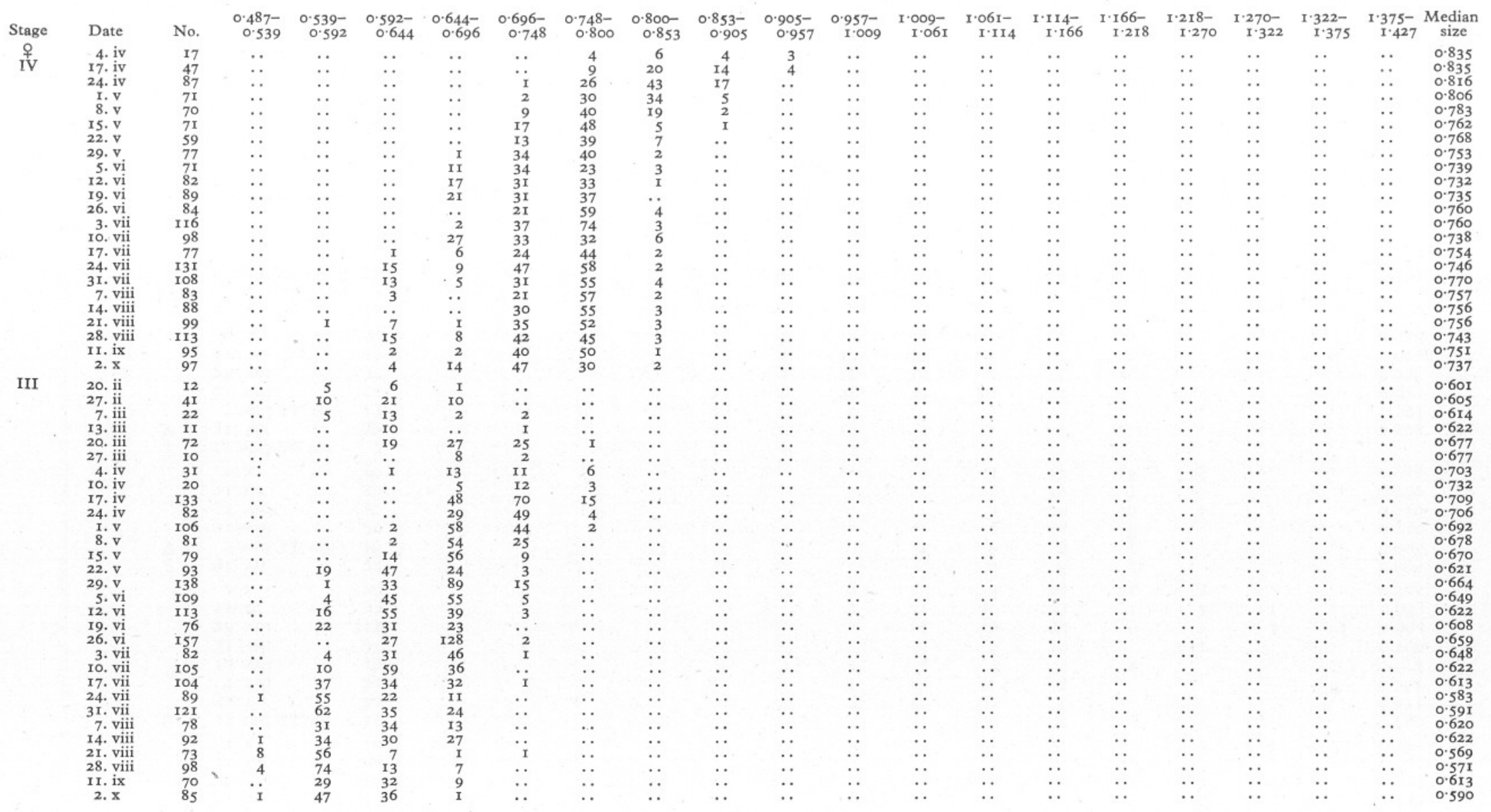


TABle XI. Size of PARACALANUS PARVUS IN MM.

\begin{tabular}{|c|c|c|c|c|c|c|c|c|c|c|c|c|c|c|c|c|c|}
\hline Stage & Date & No. & $\begin{array}{r}0.383- \\
0.418\end{array}$ & $\begin{array}{r}0.418- \\
0.452\end{array}$ & $\begin{array}{r}0.452- \\
0.487\end{array}$ & $\begin{array}{r}0.487- \\
0.522\end{array}$ & $\begin{array}{r}0.522- \\
0.557\end{array}$ & $\begin{array}{r}0.557- \\
0.592\end{array}$ & $\begin{array}{r}0.592- \\
0.626\end{array}$ & $\begin{array}{r}0.626- \\
0.661\end{array}$ & $\begin{array}{c}0.66 \mathrm{I}- \\
0.696\end{array}$ & $\begin{array}{r}0.696- \\
0.731\end{array}$ & $\begin{array}{c}0.731- \\
0.766\end{array}$ & $\begin{array}{r}0.766- \\
0.800\end{array}$ & $\begin{array}{c}0.800- \\
0.835\end{array}$ & $\begin{array}{l}0.835- \\
0.887\end{array}$ & $\begin{array}{l}\text { Median } \\
\text { size }\end{array}$ \\
\hline \multirow[t]{5}{*}{$\sigma$} & I7. vii-I4. viii & I3 & . & . & .. & . & . & . & . & . & I & 6 & 6 & .. & .. & . & 0.730 \\
\hline & 2I. viii & 21 & . & .. & . & .. & . & . & .. & .. & I & 6 & II & 2 & I & . & $0: 745$ \\
\hline & 28. viii & 75 & . & . & . & . & .. & . & . & .. & .. & I7 & 33 & 24 & I & . & 0.753. \\
\hline & II. ix & 84 & . & . & . & . & . & . & . & . & 2 & 21 & 49 & I2 & . & . & 0.747 \\
\hline & $2 . x$ & IO & . & . & . & . & . & . & . & . & . & . & I & 8 & I & . & 0.785 \\
\hline \multirow[t]{8}{*}{ 우. } & I 7 and 24 . vii & I3 & . & . & . & . & . & . & I & . & 6 & 2 & 3 & I & . & . & 0.696 \\
\hline & 31. vii & 24 & . & . & . & . & . & I & 3 & I2 & 7 & I & . & . & . & . & 0.671 \\
\hline & 7. viii & 24 & .. & . & . & . & . & . & I & IO & IO & 3 & $\therefore$ & . & . & . & 0.664 \\
\hline & I4. viii & I9 & . & .. & .. & .. & .. & .. & I & 4 & 7 & 5 & 2 & .. & .. & . & 0.678 \\
\hline & 2I. viii & $2 \mathrm{I}$ & . & . & . & . & . & .. & .. & 4 & 6 & IO & .. & I & .. & $\ldots$ & 0.700 \\
\hline & 28. viii & II3 & . & . & . & . & . & .. & . & II & 49 & 39 & 9 & I & 2 & 2 & 0.694 \\
\hline & II. ix & 93 & . & . & . & . & . & . & 5 & $2 I$ & 40 & 23 & I & 2 & I & . & 0.683 \\
\hline & 2. $\mathrm{x}$ & 70 & $\cdots$ & . & . & . & . & . & . & . & 8 & 34 & 25 & 3 & . & . & 0.725 \\
\hline \multirow{6}{*}{$\stackrel{0}{\mathrm{~V}}$} & 3I. vii & 22 & . & . & . & . & . & . & . & 3 & 9 & 8 & 2 & .. & .. & . & 0.695 \\
\hline & 7 and I4. viii & I6 & . & . & . & . & . & . & . & 2 & 6 & 7 & I & . & . & . & 0.698 \\
\hline & 2I. viii & 29 & . & . & . & . & . & . & . & . & 7 & I4 & 8 & .. & .. & .. & 0.710 \\
\hline & 28. viii & 50 & . & . & . & . & .. & .. & . & . & 3 & 26 & 20 & I & $\cdots$ & . & 0.726 \\
\hline & II. ix & 30 & . & . & . & . & . & . & . & I & 3 & I9 & 7 & .. & . & .. & $0: 720$ \\
\hline & $2 . x$ & 50 & . & . & . & $\cdots$ & . & . & . & I & 4 & 12 & 18 & 15 & $\ldots$ & . & 0.743 \\
\hline \multirow{7}{*}{ 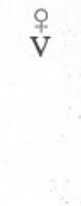 } & I7 and 24. vii & 7 & . & . & . & .. & I & 4 & 2 & . & . & $\therefore$ & . & . & . & $\ldots$ & $\therefore$ \\
\hline & 3I. vii & 36 & . & . & . & . & I & 17 & 13 & 5 & . & $\cdots$ & . & . & .. & . & 0.593 \\
\hline & 7 and I4. viii & I3 & . & . & $\ldots$ & .. & I & 6 & 6 &. & . & $\therefore$ & . & . & . & $\cdots$ & 0.591 \\
\hline & 2I. viii & 52 & . & . & $\ldots$ & .. & I & 9 & 29 & 12 & I & $\cdots$ & . & . & . & $\ldots$ & $0: 615$ \\
\hline & 28. viii & 37 & .. & . & $\cdots$ & . & $\cdots$ & 3 & I7 & I2 & 4 & I & . & $\cdots$ & .. & $\ldots$ & 0.625 \\
\hline & II. ix & 52 & . & . & . & . & . & 4 & 20 & 22 & 5 & ... & I & $\ldots$ & . & . & $0: 629$ \\
\hline & $2 . x$ & 90 & . & . & . & . & . & 2 & I4 & 44 & 26 & 2 & I & I & . & . & 0.648 \\
\hline \multirow{6}{*}{ IV } & 3r. vii $\quad \ldots$ & 53 & . & . & . & 2 & I5 & 34 & 2 & $\cdots$ & . & . & .. & . & . & .. & 0.565 \\
\hline & 7 and 14 . viii & 7 & . & . & . & I & 2 & 4 & . & . & . & $\cdots$ & . & . & .. & . & $\cdots$ \\
\hline & 2i. viii & $5 \mathrm{I}$ & .. & .. & . & . & 5 & 32 & I4 & . & . & . & . & .. & . & .. & $0.58 \mathrm{I}$ \\
\hline & 28. viii & 40 & . & . & . & . & I & 20 & I9 & . & . & . & . & . & . & . & $0.59 \mathrm{I}$ \\
\hline & II. ix & 50 & . & .. & .. & I & 4 & 25 & 20 & .. & .. & $\cdots$ & $\cdots$ & .. & .. & . & 0.587 \\
\hline & $2 . x$ & 36 & . & . & . & . & 2 & 9 & 23 & 2 & . & $\therefore$ & $\cdots$ & . & . & . & 0.602 \\
\hline \multirow{8}{*}{ I운 } & I7 and 24. vii & 8 & . & . & 2 & 4 & 2 & $\cdots$ & $\cdots$ & .. & . & . & . & . & . & . & $\ldots$ \\
\hline & 3i. vii $\quad \ldots$ & $5 \mathrm{I}$ & . & .. & 5 & 34 & II & I & . & . & .. & . & . & . & . & . & 0.510 \\
\hline & 7 and 14 . viii & I5 & . & . & I & I I & 3 & .. & .. & .. & . & .. & $\cdots$ & $\cdots$ & .. & . & 0.514 \\
\hline & 2I. viii & 50 & . & . & . & 25 & 24 & I & . & . & . & . & . & . & . & . & 0.523 \\
\hline & 28. viii & 40 & .. & . & I & I4 & $2 \mathrm{I}$ & 3 & I & . & . & . & . & . & . & . & 0.530 \\
\hline & II. ix & 85 & . & . & . & I5 & 56 & I4 & . & . & . & . & . & . & . & . & 0.538 \\
\hline & $2 . x$ & 53 & . & . & . & 8 & 35 & IO & . & $\cdots$ & $\cdots$ & $\cdots$ & . & . & . & . & 0.542 \\
\hline & I7 and 24 . vii & I3 & $\mathbf{I}$ & 5 & 7 & $\cdots$ & .. & . & $\cdots$ & . & . & . & . & . & .. & . & 0.455 \\
\hline \multirow[t]{7}{*}{ III } & 3I. vii & 90 & . & 37 & 47 & 6 & . & . & . & . & . & . & . & . & . & . & 0.458 \\
\hline & 7. viii & 39 & . & I7 & 22 & . & .. & . & . & . & $\cdots$ & . & . & . & . & . & 0.456 \\
\hline & I4. viii & 29 & .. & 13 & I6 & . & .. & $\cdots$ & . & $\cdots$ & $\cdots$ & . & . & . & . & . & 0.455 \\
\hline & 2I. viii & 78 & I & 33 & 39 & 5 & . & . & . & . & . & . & . & . & . & . & $0.45^{8}$ \\
\hline & 28. viii & 69 & 'I & $2 \mathrm{I}$ & 35 & II & I & . & . & . & . & . & . & . & . & . & 0.462 \\
\hline & II. ix & 105 & I & 37 & 54 & I3 & . & . & . & . & . & . & . & . & . & . & 0.464 \\
\hline & $2 . x$ & 78 & $\cdots$ & 9 & 52 & I6 & I & . & $\cdots$ & . & . & . & . & $\ldots$ & . & . & 0.472 \\
\hline
\end{tabular}


TABle XII. Size of MicRocalanUS pygmaEUS IN mM.

\begin{tabular}{|c|c|c|c|c|c|c|c|c|c|c|c|c|c|}
\hline Stage & Date & No. & $\begin{array}{c}0.313- \\
0.348\end{array}$ & $\begin{array}{c}0.348- \\
0.383\end{array}$ & $\begin{array}{r}0.383- \\
0.418\end{array}$ & $\begin{array}{c}0.418- \\
0.452\end{array}$ & $\begin{array}{r}0.452- \\
0.487\end{array}$ & $\begin{array}{r}0.487- \\
0.522\end{array}$ & $\begin{array}{c}0.522- \\
0.557\end{array}$ & $\begin{array}{c}0.557- \\
0.592\end{array}$ & $\begin{array}{c}0.592- \\
0.626\end{array}$ & $\begin{array}{c}0.626- \\
0.66 \mathrm{I}\end{array}$ & $\begin{array}{c}\text { Median } \\
\text { size }\end{array}$ \\
\hline \multirow[t]{21}{*}{$\sigma^{0}$} & 23. $\mathrm{i}$ & $\begin{array}{l}18 \\
20\end{array}$ & .. & .. & .. & .. & I & 3 & I4 & .. &. & .. & $\begin{array}{l}0.533 \\
0.525\end{array}$ \\
\hline & 13. it & $\begin{array}{l}29 \\
30\end{array}$ & :. & :. &.. & :. & $\because$. & $\begin{array}{l}4 \\
7\end{array}$ & $\begin{array}{l}25 \\
21\end{array}$ & $\ddot{2}$ & $\ddot{~}$. & $\because$. & $\begin{array}{l}0.535 \\
0.540\end{array}$ \\
\hline & $\begin{array}{l}20 . \text { in } \\
\text { 27. ii }\end{array}$ & $\begin{array}{r}110 \\
13\end{array}$ & 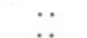 & $\because$ & :. & :. & .. & & $\begin{array}{l}85 \\
10\end{array}$ & 15 & $\because$ & $\because$ & $\begin{array}{r}0.538 \\
0.546\end{array}$ \\
\hline & 7. iii & $\begin{array}{l}13 \\
67\end{array}$ & $\because$. & $\ddot{*}$ & $\because$. & $\ddot{*}$ & $\because$. & $\ddot{2}$ & $5 \mathrm{I}$ & $\begin{array}{r}3 \\
14\end{array}$ & 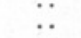 & $\because$. & $\begin{array}{l}0.540 \\
0.548\end{array}$ \\
\hline & $\begin{array}{l}33 . \\
\text { 20. iii } \\
\text { iii }\end{array}$ & $\begin{array}{l}8 \mathrm{I} \\
90\end{array}$ & $\because$ &. &. & 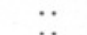 & . & $\begin{array}{l}I \\
2\end{array}$ & $\begin{array}{l}56 \\
48\end{array}$ & $\begin{array}{l}24 \\
40\end{array}$ & 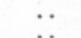 & $\because$ & $\begin{array}{l}0.551 \\
0.554\end{array}$ \\
\hline & 4. iv & $\begin{array}{l}90 \\
42\end{array}$ & $\therefore$ & $\because$ & .. & .. & .. & $\begin{array}{l}2 \\
\mathrm{I}\end{array}$ & $\begin{array}{l}48 \\
19\end{array}$ & $\begin{array}{l}40 \\
22\end{array}$ & .. & $\because$. & $\begin{array}{l}0.554 \\
0.558\end{array}$ \\
\hline & IO. iv & 85 & .. & .. & .. & ... & .. & 5 & $\begin{array}{l}19 \\
47\end{array}$ & 32 & I & .. & 0.552 \\
\hline & 17. iv & 19 & .. & .. &.. & .. & .. & $\therefore$ & 5 & 14 & & .. & 0.574 \\
\hline & 24. iv & 43 & .. & .. & .. & .. & .. & .. & 12 & 29 & 2 & .. & 0.566 \\
\hline & 8. v & $\begin{array}{l}37 \\
55\end{array}$ & .. & .. & .. & .. & .. & :. & $\begin{array}{l}12 \\
23\end{array}$ & $\begin{array}{l}23 \\
31 \\
31\end{array}$ & ${ }_{1}^{2}$ & $\because$ & $\begin{array}{l}0.564 \\
0.561\end{array}$ \\
\hline & 15. V & 78 & .. & .. & .. & .. & .. & I & 53 & 24 & .. & . & 0.550 \\
\hline & $22 . v$ & 109 & .. & .. & .. & .. & . & 7 & 93 & 9 & .. & .. & $0.54 \mathrm{I}$ \\
\hline & 29. vi & $\begin{array}{l}42 \\
54\end{array}$ & . & . & 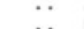 & . & * & & 20 & 12 & . &. & 0.551 \\
\hline & $12, \mathrm{yi}$ & $\begin{array}{l}34 \\
227\end{array}$ & & . & $\because$ & $\because$ & $\because$ & $\ddot{\ddot{I}}$ & $\begin{array}{l}399 \\
57\end{array}$ & 13 & $\because$ & $\because$ & $\begin{array}{l}0.549 \\
0.5452\end{array}$ \\
\hline & 26. vi & 56 & & .. & $\therefore$ & $\therefore$ &.. & 5 & $\begin{array}{l}41 \\
44\end{array}$ & 7 & $\therefore$ & $\therefore$ & $\begin{array}{l}0.522 \\
0.540\end{array}$ \\
\hline & 3. vii & 95 & .. & .. & .. & .. & .. & 17 & 72 & 6 & .. & .. & 0.533 \\
\hline & Io. vil & 75 & .. & .. & $\cdots$ & .. & .. & 23 & 52 & $\because \ddot{\theta}$ & .. & .. & 0.529 \\
\hline & 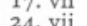 & 47 & . & .. &. & . & . & & 31 & 8 & .. &. & $\begin{array}{l}0.539 \\
\end{array}$ \\
\hline & 31. vii vit & 20 & $\because$ & $\because$ & $\because$ & $\because$ & $\because$ & 4 & 10 & $\cdots$ & & 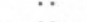 & $\begin{array}{r}0.531 \\
0.53\end{array}$ \\
\hline & 7. viii & 27 & $\therefore$ &.. & $\therefore$ & $\therefore$ & .. & & 18 & $\because$ & $\because$ & $\therefore$ & $\begin{array}{l}0.530 \\
0.529\end{array}$ \\
\hline & I4. viii & 28 & .. & .. & .. & . & $\therefore$ & 15 & 13 & .. & .. & .. & 0.522 \\
\hline \multirow[t]{28}{*}{ q } & 17. i & 35 & .. & .. & .. & .. & .. & 9 & 24 & 2 & .. & .. & 0.533 \\
\hline & $\begin{array}{l}23 . \\
30\end{array}$ & 64 & .. & . &.. & .. & & 15 & 46 & 3 & .. & .. & $\begin{array}{l}0.535 \\
0.525\end{array}$ \\
\hline & 6. ii & $\begin{array}{l}20 \\
93\end{array}$ & $\because$. & .. & $\because$. &.. & .. & $\begin{array}{l}I_{26}^{4} \\
26\end{array}$ & $\begin{array}{l}\text { II } \\
60\end{array}$ & $\frac{1}{7}$ & .. &.. & $\begin{array}{l}0.521 \\
0.532\end{array}$ \\
\hline & $\begin{array}{l}\text { 13. ii } \\
\text { 20. ii }\end{array}$ & $\begin{array}{l}67 \\
59\end{array}$ & &. & . &. & . & 6 & 54 & $7^{7}$ & 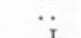 &. & $\begin{array}{l}0.539 \\
0.550\end{array}$ \\
\hline & 27. ii & 105 & .. & .. & .. & .. & .. & 6 & 53 & 45 & I & .. & $\begin{array}{r}.5552 \\
\end{array}$ \\
\hline & 7. iiii & $7 \mathrm{I}$ & .. & .. & .. & .. & .. & $I$ & & 47 & 5 & .. & 0.566 \\
\hline & $20 . \mathrm{iii}$ & $\begin{array}{l}74 \\
76\end{array}$ & $\because$ & . & . & . & . & $\ddot{2}$ & $\begin{array}{l}15 \\
14\end{array}$ & $\begin{array}{l}50 \\
46\end{array}$ & $\begin{array}{r}9 \\
14\end{array}$ & . & $\begin{array}{l}0.571 \\
0.574\end{array}$ \\
\hline & 27. iii & 27 & .. & & & & .. & $\because$ & 9 & 16 & 2 & .. & 0.568 \\
\hline & 4. iv & 69 & & &.. & .. & .. & I & II & 31 & 25 & I & 0.583 \\
\hline & iv & $\begin{array}{l}122 \\
78\end{array}$ & $\cdots$ & $\because$ & $\because$ & $\because$ & . & 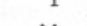 & 12 & 72 & 32 & 1 & $\begin{array}{l}0.581 \\
0.88\end{array}$ \\
\hline & 24 , iv & 89 & $\therefore$ & $\because$ & $\because$ & $\therefore$ & $\because$ & $\because$ & 0 & 50 & 30 & $\because$ & $\begin{array}{l}-580 \\
0.884\end{array}$ \\
\hline & I. v & 88 & .. & 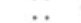 &. & $\therefore$ & & & 7 & 52 & 28 & I & $\begin{array}{l}\begin{array}{l}584 \\
0.584\end{array}\end{array}$ \\
\hline & 8. $\mathrm{v}$ & 102 & & .. &.. & .. & .. & 2 & 23 & 65 & II & I & 0.570 \\
\hline & $15 . \mathrm{v}$ & 105 & .. & * & .. & .. & .. & $\because$ & & 67 & II & $I$ & 0.569 \\
\hline & & $\begin{array}{l}103 \\
5\end{array}$ & $\cdots$ & .. & .. & . & . & 1 & $0^{3}$ & $3^{\circ}$ & 3 &.$\cdot$ & 0.551 \\
\hline & $5, \mathrm{yi}$ & 26 & $\because$ & $\because$ & $\because$ & $\because$ & $\because$ & & 64 & 19 & 0 & 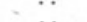 & $\begin{array}{l}0.562 \\
0.585\end{array}$ \\
\hline & 12. vi & 88 & .. & $\therefore$ &.. & $\therefore$ & $\therefore$ & $3_{3}$ & 33 & 43 & 9 & $\therefore$ & $\begin{array}{l}\begin{array}{l}0.555 \\
0.5662\end{array} \\
0.56\end{array}$ \\
\hline & 19. vi & 118 & .. & . & .. &.. & .. & & 58 & 49 & II & .. & 0.558 \\
\hline & 26. vi & 115 & .. & . & .. &.. & .. & 2 & 33 & 65 & 15 & .. & 0.567 \\
\hline & 3. vit & $\begin{array}{l}129 \\
129\end{array}$ & .. & & & .. & .. & & 61 & 55 & 5 & $\because$ & 0.555 \\
\hline & & $\mathrm{III}_{2}$ & $\because$ & $\because$ & $\because$ & $\because$ & $\cdots$ & 7 & 47 & ${ }_{58}^{4}$ & 6 & 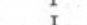 & 0.555 \\
\hline & 24. vii & 62 & . & $\because$ & : & $\because$ & $\because$ & 8 & & II & I & . & $\begin{array}{l}0.511 \\
0.5442\end{array}$ \\
\hline & 3i. vii & 92 & .. & & . & .. & .. & 16 & 59 & 17 & & . & 0.542 \\
\hline & 7 & $8 \mathrm{I}$ & .. &. & &.. & .. & $3 I$ & 4 & 9 & I & .. & 0.529 \\
\hline & $\mathrm{I}_{4}$ & 82 & .. & & &. & .. & 26 & 45 & 10 & I & .. & 0.533 \\
\hline & $\begin{array}{l}21 . \mathrm{vul} \\
28 \mathrm{viij}\end{array}$ & $\begin{array}{l}97 \\
63\end{array}$ & 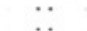 & $\because$. & . & 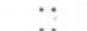 & $\begin{array}{l}1 \\
2\end{array}$ & $\begin{array}{l}43 \\
3 I\end{array}$ & $\begin{array}{l}44 \\
26\end{array}$ & $\begin{array}{l}9 \\
3\end{array}$ & $\ddot{I}$ & $\because$. & $\begin{array}{l}0.525 \\
0.5222\end{array}$ \\
\hline & II. ix & & $\cdots$ & .. & .. & .. & I & 38 & 37 & 2 &.. & .. & 0.522 \\
\hline & & 29 & .. & & & & I & 22 & & .. & .. & & \\
\hline \multirow{13}{*}{$\mathrm{d}$} & 17. $\mathrm{i}$ & 20 & .. & .. & .. & .. & 4 & 15 & I & .. & .. & .. & $\begin{array}{l}0.497 \\
0\end{array}$ \\
\hline & $30 . \mathrm{i}$ & $\begin{array}{l}71 \\
20\end{array}$ & .. & & .. & .. & 1 & $\begin{array}{l}39 \\
14\end{array}$ & 4 & & . & :. & $\begin{array}{r}0.508 \\
0.513\end{array}$ \\
\hline & 6. ii & 57 & .. & &.. & $\therefore$ & 2 & 38 & 16 & I & .. & $\because$. & 0.516 \\
\hline & $\begin{array}{l}13 . \\
20\end{array}$ & 42 & .. & $\cdots$ & . & . & & 22 & 20 & 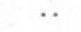 & .. & . & $\begin{array}{l}0.5222 \\
0.567\end{array}$ \\
\hline & & 42 & .. & . & . & .. & $\because$ & 23 & & $\cdot$. & .. & .. & $0.52 I$ \\
\hline & 7. & $6 \mathrm{x}$ & $\because$ & $\cdot$ & $\cdots$ & $\because$ & 1 & $\begin{array}{l}30 \\
16\end{array}$ & 4 & $\ddot{2}$ & $\because$ & $\because$ & $\begin{array}{l}0.521 \\
0.532\end{array}$ \\
\hline & & 43 & $\therefore$ & . & .. & $\therefore$ & .. & 7 & & 4 & $\therefore$ & $\therefore$ & $\begin{array}{l}0.322 \\
0.433\end{array}$ \\
\hline & 20. iii & 53 & & & . &.. & & 5 & & 7 & .. & .. & $0.54 \mathrm{~T}$ \\
\hline & & 22 & . & . & & .. & & 2 & i8 & 2 & .. & .. & 0.539 \\
\hline & & 58 & .. & . & . & .. & .. & 3 & 4 & 10 & .. & .. & 0.546 \\
\hline & 24 , iv & $\begin{array}{c}30 \\
56\end{array}$ & $\because$ & : & $\because$ & $\because$ & . & & 25 & 9 & $\cdots$ & . & $\begin{array}{l}0.549 \\
0.5\end{array}$ \\
\hline & I. v & 75 & $\therefore$ & $\therefore$ & $\therefore$ & $\because$ & $\because$ & 9 & 57 & 9 & $\because$ & $\because$ & $\begin{array}{l}0.542 \\
0.54\end{array}$ \\
\hline & $8 \mathrm{v}$. & 69 & $\because$. & : & . &. & . & 27 & $\begin{array}{l}54 \\
46\end{array}$ & 4 & $\ddot{0}$ & .. & $\begin{array}{l}0.535 \\
0.525\end{array}$ \\
\hline & & & & & & & & 27 & & & . & & 0.527 \\
\hline
\end{tabular}




\section{TABLE XII (cont.)}

\begin{tabular}{|c|c|c|c|c|c|c|c|c|c|c|c|c|c|}
\hline Stage & Date & No. & $\begin{array}{l}0.313- \\
0.348\end{array}$ & $\begin{array}{l}0.348- \\
0.383\end{array}$ & $\begin{array}{l}0.383- \\
0.418\end{array}$ & $\begin{array}{c}0.418- \\
0.452\end{array}$ & $\begin{array}{c}0.452- \\
0.487\end{array}$ & $\begin{array}{c}0.487- \\
0.522\end{array}$ & $\begin{array}{c}0.522- \\
0.557\end{array}$ & $\begin{array}{c}0.557- \\
0.592\end{array}$ & $\begin{array}{c}0.592- \\
0.626\end{array}$ & $\begin{array}{c}0.626- \\
0.661\end{array}$ & $\begin{array}{l}\text { Median } \\
\text { size }\end{array}$ \\
\hline \multirow{13}{*}{ o } & 22. v & 48 & $\cdots$ & $\cdots$ & $\cdots$ & . & . & I5 & 32 & I & $\cdots$ & .. & 0.530 \\
\hline & 29. v & 33 & $\cdots$ & $\cdots$ & $\cdots$ & $\cdots$ & $\cdots$ & 5 & 26 & 2 & $\ldots$ & . & 0.534 \\
\hline & 5. vi & $\begin{array}{l}\text { I3 } \\
56\end{array}$ & $\because$ & $\cdots$ & $\cdots$ & $\cdots$ & $\cdots$ & $\cdots$ & IO & 3 & $\cdots$ & $\cdots$ & 0.534 \\
\hline & $\begin{array}{l}\text { I2. v1 } \\
\text { I9. vi }\end{array}$ & $\begin{array}{l}56 \\
28\end{array}$ & $\cdots$ & $\cdots$ & $\cdots$ & $\cdots$ & $\cdots$ & 6 & 48 & 2 & $\cdots$ & $\cdots$ & 0.535 \\
\hline & $\begin{array}{l}\text { 19. v1 } \\
\text { 26. vi }\end{array}$ & $\begin{array}{l}28 \\
66\end{array}$ & $\therefore$ & $\cdots$ & $\cdots$ & $\ddot{T}$ & $\cdots$ & 5 & 23 & $\cdots$ & $\cdots$ & $\cdots$ & 0.534 \\
\hline & 3. vii & 66 & 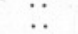 & $\because$ & $\cdots$ & I & 4 & 42 & I9 & $\cdots$ & $\cdots$ & $\cdots$ & 0.514 \\
\hline & Io. vii & 79 & 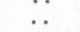 & $\ddot{x}$ & $\because$ & $\cdots$ & 3 & 43 & 20 & $\cdots$ & $\cdots$ & $\cdots$ & 0.513 \\
\hline & I7. vii & 62 & . & $\cdots$ & 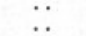 & $\cdots$ & 3 & 53 & 23 & $\cdots$ & $\cdots$ & $\cdots$ & 0.514 \\
\hline & 24. vii & 53 & $\cdots$ & . & & $\because$ & $\therefore$ & $\begin{array}{l}37 \\
29\end{array}$ & 25 & $\because$ & $\cdots$ & $\cdots$ & 0.519 \\
\hline & 3r. vii & 69 & . & . & $\ldots$ & $\ddot{0}$ & $\therefore$ & $\begin{array}{l}29 \\
51\end{array}$ & $\begin{array}{l}24 \\
18\end{array}$ & $\cdots$ & $\cdots$ & $\cdots$ & 0.520 \\
\hline & 7. viii & 26 & $\cdots$ & . & . & $\cdots$ & 3 & $2 I$ & $\begin{array}{r}\text { I8 } \\
2\end{array}$ & $\because$ & $\cdots$ & $\cdots$ & 0.515 \\
\hline & I4. viii & $3 I$ & $\cdots$ & . & . & I & 4 & 24 & $\begin{array}{l}2 \\
2\end{array}$ & $\cdots$ & $\cdots$ & $\cdots$ & 0.500 \\
\hline & 28. viii & I5 & $\cdots$ & $\cdots$ & $\ldots$ & $\cdots$ & 4 & II & $\therefore$ & $\cdots$ & $\cdots$ & $\cdots$ & 0.503 \\
\hline \multirow{32}{*}{$\stackrel{\circ}{\mathrm{V}}$} & II. ix & I3 & $\cdots$ & $\cdots$ & $\cdots$ & $\cdots$ & 3 & IO & $\begin{array}{l}\cdots \\
\cdots\end{array}$ & $\cdots$ & $\cdots$ & $\cdots$ & 0.497 \\
\hline & I7. $\mathrm{i}$ & 10 & . & . & . & 4 & 6 & . & $\cdots$ & $\cdots$ & $\cdots$ & $\cdots$ & 0.499 \\
\hline & 23. i & 79 & $\cdots$ & . & . & 9 & 64 & 5 & $\ddot{I}$ & $\cdots$ & . & . & 0.456 \\
\hline & 30. $\mathrm{i}$ & I5 & $\cdots$ & $\cdots$ & $\cdots$ & 5 & 9 & I & $\begin{array}{r}\mathrm{I} \\
.\end{array}$ & $\cdots$ & $\cdots$ & $\ldots$ & 0.465 \\
\hline & 6. ii & 46 & $\cdots$ & . & $\cdots$ & 5 & 36 & 5 & $\because$ & $\cdots$ & $\cdots$ & $\cdots$ & 0.459 \\
\hline & I3. ii & 35 & $\cdots$ & $\cdots$ & .. & 4 & 28 & 3 & $\cdots$ & $\cdots$ & $\cdots$ & $\cdots$ & 0.467 \\
\hline & 20. ii & 57 & $\cdots$ & $\cdots$ & .. & 6 & $4 I$ & ro & $\ddot{*}$ & $\cdots$ & $\cdots$ & $\cdots$ & 0.468 \\
\hline & 27. ii & 27 & $\cdots$ & .. & $\cdots$ & 2 & 23 & 2 & $\ddot{x}$ & $\cdots$ & $\cdots$ & $\cdots$ & 0.474 \\
\hline & 7. iii & 52 & $\cdots$ & $\cdots$ & .. & $\cdots$ & 30 & 22 & $\ddot{*}$ & $\cdots$ & $\cdots$ & $\cdots$ & 0.469 \\
\hline & 13. iii & 42 & $\cdots$ & $\cdots$ & . & I & 9 & 30 & $\ddot{I}$ & $\because$ & $\cdots$ & $\cdots$ & 0.485 \\
\hline & 20. iii & $3 I$ & $\cdots$ & $\cdots$ & $\cdots$ & $\cdots$ & 9 & 20 & $\begin{array}{l}1 \\
2\end{array}$ & I & $\cdots$ & $\cdots$ & 0.497 \\
\hline & 4. iv & 17 & $\cdots$ & . & .. & $\cdots$ & 3 & II & $\begin{array}{l}2 \\
3\end{array}$ & $\cdots$ & $\cdots$ & $\cdots$ & 0.495 \\
\hline & I0. iv & 38 & . & $\cdots$ & .. & $\ldots$ & 2 & 33 & $\begin{array}{l}3 \\
3\end{array}$ & $\cdots$ & $\cdots$ & $\cdots$ & 0.508 \\
\hline & I7. iv & 29 & . & $\cdots$ & $\cdots$ & $\cdots$ & I & 24 & $\begin{array}{l}3 \\
4\end{array}$ & $\cdots$ & $\cdots$ & $\cdots$ & 0.508 \\
\hline & 24. iv & 36 & . & $\cdots$ & $\cdots$ & $\ldots$ & I & $3 I$ & $\begin{array}{l}4 \\
4\end{array}$ & $\cdots$ & $\cdots$ & $\cdots$ & 0.511 \\
\hline & I. V & 50 & $\cdots$ & $\cdots$ & .. & .. & 6 & 38 & $\begin{array}{l}4 \\
6\end{array}$ & $\cdots$ & $\cdots$ & $\cdots$ & 0.509 \\
\hline & 8. v & 40 & $\cdots$ & $\cdots$ & . & $\ldots$ & 9 & 28 & 3 & $\cdots$ & $\cdots$ & $\cdots$ & 0.503 \\
\hline & I5. v & 59 & . & $\cdots$ & $\cdots$ & $\cdots$ & 34 & 25 & $\begin{array}{l}3 \\
. .\end{array}$ & $\cdots$ & $\cdots$ & $\cdots$ & 0.497 \\
\hline & 22. v & 86 & . & . & $\cdots$ & I & 35 & 48 & $\ddot{2}$ & $\cdots$ & $\cdots$ & $\cdots$ & 0.485 \\
\hline & 29. v & 12 & $\cdots$ & . & $\cdots$ & . & I & 8 & 3 & $\cdots$ & $\cdots$ & $\cdots$ & 0.490 \\
\hline & 5. vi & 22 & $\cdots$ & $\cdots$ & . & I & 4 & 17 & $\begin{array}{l}3 \\
.\end{array}$ & $\cdots$ & $\cdots$ & $\cdots$ & 0.499 \\
\hline & 12. vi & 56 & . & $\cdots$ & . & . & 16 & 38 & $\ddot{2}$ & $\cdots$ & $\cdots$ & $\cdots$ & 0.496 \\
\hline & I9. vi & 41 & .. & $\cdots$ & . & I & I 7 & 20 & 3 & $\cdots$ & $\cdots$ & $\cdots$ & 0.495 \\
\hline & 26. vi & 87 & $\cdots$ & $\cdots$ & $\cdots$ & 17 & 62 & 8 & $\begin{array}{r}3 \\
.\end{array}$ & $\cdots$ & $\cdots$ & $\cdots$ & 0.490 \\
\hline & 3. vii & 53 & $\cdots$ & . & $\cdots$ & 13 & 39 & I & $\ddot{x}$ & $\cdots$ & $\cdots$ & $\cdots$ & 0.464 \\
\hline & Io. vii & 69 & $\cdots$ & $\cdots$ & $\cdots$ & I3 & 56 & $\ldots$ & $\ddot{0}$ & $\cdots$ & $\cdots$ & $\cdots$ & $0.46 \mathrm{I}$ \\
\hline & 17. vii & 60 & $\cdots$ & $\cdots$ & $\cdots$ & 4 & 44 & II & $\ddot{I}$ & $\cdots$ & $\cdots$ & $\cdots$ & 0.462 \\
\hline & 24. vii & 49 & $\cdots$ & $\cdots$ & $\cdots$ & I & 43 & 5 & I & $\cdots$ & $\cdots$ & $\cdots$ & 0.476 \\
\hline & 31. vii. & 82 & . & $\ldots$ & $\ldots$ & I5 & 63 & 4 & $\cdots$ & $\cdots$ & $\cdots$ & $\cdots$ & 0.473 \\
\hline & 7. viii & 28 & . & $\cdots$ & $\cdots$ & Io & I8 & $\begin{array}{r}4 \\
\ldots\end{array}$ & $\cdots$ & $\cdots$ & $\cdots$ & . & 0.462 \\
\hline & I4. viii & 48 & $\ldots$ & $\ldots$ & $\ldots$ & 23 & & & $\cdots$ & $\cdots$ & $\cdots$ & $\cdots$ & 0.457 \\
\hline & II. ix & I I & $\cdots$ & $\cdots$ & $\cdots$ & 5 & 6 & $\because$ & $\because$ & $\cdots$ & $\cdots$ & $\cdots$ & 0.453 \\
\hline \multirow{30}{*}{ IV } & 17. i & 34 & . & $\ldots$ & I4 & 20 & . & $\cdots$ & $\cdots$ & $\cdots$ & $\cdots$ & $\cdots$ & 0.455 \\
\hline & $23 . \mathrm{i}$ & 43 & $\cdots$ & $\cdots$ & 9 & 33 & $\ddot{I}$ & $\because$ & $\cdots$ & $\cdots$ & $\cdots$ & $\cdots$ & 0.422 \\
\hline & 30. i. & 23 & . & $\cdots$ & I9 & 4 & $\ldots$ & $\cdots$ & $\cdots$ & $\cdots$ & $\cdots$ & $\cdots$ & 0.429 \\
\hline & 6. ii & 45 & $\cdots$ & . & I7 & 28 & $\ldots$ & $\because$ & $\cdots$ & $\cdots$ & $\cdots$ & $\cdots$ & 0.410 \\
\hline & I3. ii & 38 & $\cdots$ & $\cdots$ & 9 & 29 & . & $\begin{array}{l}\cdots \\
\cdots\end{array}$ & $\cdots$ & $\cdots$ & $\cdots$ & $\cdots$ & 0.422 \\
\hline & 20. ii & $6 I$ & $\cdots$ & $\cdots$ & 5 & 55 & I & $\cdots$ & $\cdots$ & $\cdots$ & $\cdots$ & $\cdots$ & 0.426 \\
\hline & 27. ii & 55 & $\cdots$ & $\cdots$ & 8 & 46 & I & $\begin{array}{l}\cdots \\
\cdots\end{array}$ & $\cdots$ & $\cdots$ & $\cdots$ & $\cdots$ & 0.432 \\
\hline & 7. iii & 32 & $\cdots$ & $\cdots$ & $\cdots$ & $3 I$ & I & $\because$ & $\cdots$ & $\cdots$ & $\cdots$ & $\cdots$ & 0.430 \\
\hline & I3. iii & 38 & $\cdots$ & $\cdots$ & $\cdots$ & 35 & 3 & $\begin{array}{l}\cdots \\
\cdots\end{array}$ & $\cdots$ & $\cdots$ & $\cdots$ & $\cdots$ & 0.438 \\
\hline & 20. iii & I4 & $\cdots$ & $\cdots$ & $\cdots$ & 8 & 6 & $\because$ & $\cdots$ & $\cdots$ & $\cdots$ & $\cdots$ & 0.439 \\
\hline & 4. iv & 23 & . & $\cdots$ & $\cdots$ & I3 & IO & $\because$ & $\cdots$ & $\cdots$ & $\cdots$ & $\cdots$ & $0.45 \mathrm{I}$ \\
\hline & Io. iv & $4 I$ & $\cdots$ & . & 2 & 22 & I7 & $\because$ & $\cdots$ & $\cdots$ & $\cdots$ & $\cdots$ & $0.45 \mathrm{I}$ \\
\hline & I7. iv & 27 & . & . & $\ldots$ & 8 & I8 & $\ddot{I}$ & $\cdots$ & $\cdots$ & $\cdots$ & $\cdots$ & 0.450 \\
\hline & 24. iv & 60 & . & $\cdots$ & . & 29 & $3 I$ & $\ldots$ & $\cdots$ & $\cdots$ & $\cdots$ & $\cdots$ & 0.459 \\
\hline & I. V & 71 & $\cdots$ & . & .. & $4 I$ & 30 & $\begin{array}{l}\cdots \\
\cdots\end{array}$ & $\cdots$ & $\cdots$ & $\cdots$ & $\cdots$ & 0.453 \\
\hline & 8. v & 57 & . & $\cdots$ & . & 25 & 32 & $\because$ & $\cdots$ & $\cdots$ & $\cdots$ & $\cdots$ & 0.450 \\
\hline & I5. V & 56 & .. & .. & 2 & 46 & 8 & $\ddot{*}$ & $\cdots$ & $\cdots$ & $\cdots$ & $\cdots$ & 0.454 \\
\hline & 22. v. & I 6 & . & $\cdots$ & 2 & 12 & 2 & $\because$ & $\cdots$ & $\cdots$ & $\cdots$ & $\cdots$ & $0.44 \mathrm{I}$ \\
\hline & 5. vi & I3 & . & $\cdots$ & $\cdots$ & IO, & 3 & $\because$ & $\cdots$ & $\cdots$ & $\cdots$ & $\cdots$ & 0.443 \\
\hline & I2. vi & 57 & $\ldots$ & . & 3 & 39 & I5 & 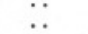 & $\cdots$ & $\cdots$ & $\cdots$ & $\cdots$ & 0.447 \\
\hline & I9. vi & 33 & $\cdots$ & $\cdots$ & 3 & 26 & 4 & $\because$ & $\cdots$ & $\cdots$ & $\cdots$ & $\cdots$ & 0.445 \\
\hline & 26. vi & 38 & $\cdots$ & $\cdots$ & 9 & 29 & $\ldots$ & $\because$ & $\cdots$ & $\cdots$ & $\cdots$ & $\cdots$ & 0.435 \\
\hline & 3. vii & 51 & $\cdots$ & $\ldots$ & I 8 & 33 & . & 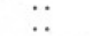 & $\cdots$ & $\cdots$ & $\cdots$ & $\cdots$ & 0.425 \\
\hline & 10. vii & 47 & . & . & I I & 36 & .. & $\because$ & $\cdots$ & $\cdots$ & $\cdots$ & $\cdots$ & 0.424 \\
\hline & I7. vii & 45 & . & $\cdots$ & I & $4 \mathrm{I}$ & 3 & $\because$ & $\cdots$ & $\cdots$ & $\cdots$ & $\cdots$ & 0.427 \\
\hline & 24. vii & 32 & . & .. & 3 & 29 & & $\cdots$ & $\cdots$ & $\cdots$ & $\cdots$ & $\cdots$ & 0.439 \\
\hline & 3r. vii. & I9 & . & .. & 9 & 10 & 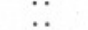 & $\because$ & $\cdots$ & $\cdots$ & $\cdots$ & $\cdots$ & 0.428 \\
\hline & 7. viii & I2 & .. & . & 4 & 8 & 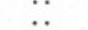 & $\cdots$ & $\cdots$ & $\cdots$ & $\cdots$ & $\cdots$ & 0.420 \\
\hline & I4. viii & IO & .. & $\cdots$ & 5 & 5 & $\ddot{*}$ & $\cdots$ & $\cdots$ & $\cdots$ & $\cdots$ & $\cdots$ & 0.425 \\
\hline & & & & & & & $\cdots$ & $\cdots$ & $\cdots$ & $\cdots$ & $\cdots$ & $\cdots$ & 0.420 \\
\hline
\end{tabular}




\section{TABLE XII (cont.)}

\begin{tabular}{|c|c|c|c|c|c|c|c|c|c|c|c|c|c|}
\hline Stage & Date & No. & $\begin{array}{r}0.313- \\
0.348\end{array}$ & $\begin{array}{r}0.348- \\
0.383\end{array}$ & $\begin{array}{r}0.383- \\
0.418\end{array}$ & $\begin{array}{r}0.418- \\
0.452\end{array}$ & $\begin{array}{r}0.452- \\
0.487\end{array}$ & $\begin{array}{r}0.487- \\
0.522\end{array}$ & $\begin{array}{r}0.522- \\
0.557\end{array}$ & $\begin{array}{r}0.557- \\
0.592\end{array}$ & $\begin{array}{r}0.592- \\
0.626\end{array}$ & $\begin{array}{r}0.626- \\
0.66 \mathrm{I}\end{array}$ & $\begin{array}{c}\text { Median } \\
\text { size }\end{array}$ \\
\hline \multirow{28}{*}{ IV } & 17. i & $\begin{array}{l}40 \\
68\end{array}$ & . & 7 & 32 & I & $\because$ & $\cdots$ & . & .. & . & .. & 0.394 \\
\hline & $\begin{array}{l}23.1 \\
30.1\end{array}$ & $\begin{array}{l}08 \\
12\end{array}$ & $\because$. & $\frac{1}{7}$ & 65 & $\begin{array}{l}2 \\
. .\end{array}$ & $\because$. & $\because$ & $\because$. & $\because$. & $\because$ & $\because$ & $\begin{array}{l}0.398 \\
0.381\end{array}$ \\
\hline & 6. ii & 32 & $\because$. & 6 & 26 & $\because$. & $\because$. & $\because$. & $\because$. & $\because$. & $\because$. & $\because$. & $\begin{array}{l}0.38 \mathrm{I} \\
0.393\end{array}$ \\
\hline & 13. ii & 36 & $\ldots$ & 2 & 34 & $\because$. & $\because$. & $\because$. & .. & $\because$. & $\because$. & $\because$. & 0.400 \\
\hline & 20. ii & 48 & .. & 2 & 42 & 4 & .. & .. & . & $\ldots$ & . & $\ldots$ & 0.404 \\
\hline & 27. ii & 35 & .. & $\because$ & 30 & 5 & . & $\cdots$ & .. & .. & .. & . & 0.402 \\
\hline & 7. iii & 28 & $\ldots$ & I & 26 & I & $\ldots$ & $\ldots$ & .. & .. & $\ldots$ & $\therefore$ & 0.406 , \\
\hline & I3. iii & 42 & $\ldots$ & .. & 24 & I8 & .. & $\ldots$ & $\ldots$ & $\ldots$ & .. & .. & 0.415 \\
\hline & 20. iii & II & .. & $\ldots$ & 7 & 4 & $\because$. & $\because$. & $\because$. & $\because$. & $\because$. & $\because$. & 0.413 \\
\hline & 4. iv & 30 & $\ldots$ & .. & 4 & 26 & 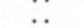 & $\therefore$ & $\because$. & $\because$. & $\because$ & $\because$ & 0.427 \\
\hline & Io. iv & 39 & .. & $\ldots$ & I & 38 & $\because$. & $\because$. & $\because$ & $\because$. & $\because$. & $\because$. & 0.428 \\
\hline & 17. iv & 23 & . & $\ldots$ & 4 & I7 & 2 & .. & . & .. & .. & .. & $0.43^{8}$ \\
\hline & 24. iv & $6 \mathrm{I}$ & .. & .. & II & 47 & 3 & $\cdots$ & .. & .. & .. & $\ldots$ & 0.427 \\
\hline & I. V & 63 & $\ldots$ & $\ldots$ & 15 & 46 & 2 & $\ldots$ & $\ldots$ & $\ldots$ & .. & $\ldots$ & 0.427 \\
\hline & $8 . \mathrm{v}$ & 38 & $\ldots$ & . & 9 & 28 & I & .. & .. & .. & . & .. & 0.427 \\
\hline & I5. v & 51 & .. & $\ldots$ & $3 \mathrm{I}$ & I9 & I & .. & .. & .. & $\therefore$ & $\therefore$ & 0.414 \\
\hline & 22. v & 25 & $\ldots$ & . & 14 & II &.. & $\because$. & $\because$. & $\because$. & $\because$ & $\because$ & 0.416 \\
\hline & 5. vi & I4 & $\because$. & $\because$. & $\begin{array}{r}4 \\
3\end{array}$ & II & $\because$. & $\because$ & $\because$ & $\because$. & $\because$. & $\because$ & $\begin{array}{l}4.427 \\
0.427\end{array}$ \\
\hline & I2. vi & 59 & .. & .. & 18 & $4 \mathrm{I}$ & $\because$ & $\because$ & $\because$ & $\because$ & $\because$ & $\because$ & 0.424 \\
\hline & I9. vi & 4I & .. & I & 24 & 14 & 2 & $\because$ & $\because$ & $\because$ & $\because$ & $\because$ & $\begin{array}{l}0.424 \\
0.414\end{array}$ \\
\hline & 26. vi & 75 & $\because$ & 5 & $\begin{array}{l}64 \\
67\end{array}$ & $\begin{array}{r}44 \\
3\end{array}$ &.. & $\because$ & $\because$ & $\because$ & $\because$ & $\because$ & $\begin{array}{l}0.414 \\
0.307\end{array}$ \\
\hline & 3. vii & 69 & $\because$ & 13 & 55 & ${ }_{1}^{3}$ & $\because$ & $\because$ & $\because$ & $\because$ & $\because$ & $\because$ & $\begin{array}{l}0.397 \\
0.302\end{array}$ \\
\hline & I0. vii & 70 & .. & 3 & 62 & 5 & $\because$ & $\because$ & . & $\because$ & $\because$ & $\because$ & $\begin{array}{l}0.392 \\
0.399\end{array}$ \\
\hline & 17. vii & 69 & $\ldots$ & I & 48 & 20 & $\therefore$ & $\because$ & $\because$. & $\because$. & $\because$. & $\because$ & 0.410 \\
\hline & 24. vii & $4 \mathrm{I}$ & . & 2 & 37 & 2 & .. & $\ldots$ & $\ldots$ & $\ldots$ & .. & $\because$ & 0.398 \\
\hline & 3i. vii & 37 & .. & 9 & 27 & I & $\ldots$ & . & .. & .. & . & .. & 0.393 \\
\hline & 7. viii & 18 & .. & 4 & 13 & I & $\ldots$ & $\ldots$ & $\ldots$ & 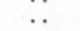 & $\because$. & . & 0.395 \\
\hline & I4. viii & 8 & .. & 2 & 6 & .. & $\cdots$ & .. & .. & $\cdots$ & .. & .. & 0.392 \\
\hline \multirow[t]{29}{*}{ III } & 17. i & 71 & 22 & 49 & .. & .. & .. & .. & .. & .. & .. & .. & 0.354 \\
\hline & 23. i & 33 & I8 & I5 & $\ldots$ & . & .. & .. & $\ldots$ & $\ldots$ & .. & .. & 0.347 \\
\hline & 30. i & 19 & 12 & 7 & . & . & $\ldots$ & . &.. & $\ldots$ & .. & $\ldots$ & 0.345 \\
\hline & 6. ii & 56 & 22 & 34 & $\because$ & $\because$. & $\because$. & $\because$. & $\because$. & $\because$. & $\because$. & $\because$. & 0.352 \\
\hline & 13. ii & 137 & 75 & 62 & $\ldots$ & .. & .. & . & $\because$ & $\because$. & $\because$ & $\because$. & 0.347 \\
\hline & 20. ii & 68 & 19 & 48 & $\ddot{I}$ & $\because$. & $\because$. & .. & $\because$. & $\ldots$ & $\ldots$ & $\ldots$ & 0.355 \\
\hline & 27. ii & 83 & 39 & 44 & .. & $\cdots$ & . & . & $\cdots$ & $\cdots$ & $\ldots$ & $\cdots$ & 0.350 \\
\hline & 7. iii & 50 & 13 & 37 & .. & $\cdots$ & .. & $\cdots$ & .. & $\cdots$ & .. & $\ldots$ & 0.355 \\
\hline & 13. iii & 46 & 4 & 38 & 4 & .. & $\ldots$ & $\ldots$ & $\ldots$ & $\ldots$ & $\ldots$ & .. & 0.367 \\
\hline & 20. iii & 19 & I & 16 & i & I & $\ldots$ & $\ldots$ & $\ldots$ & .. & $\ldots$ & $\ldots$ & 0.362 \\
\hline & 27. iii & 59 & 3 & 56 & .. & .. & .. & $\ldots$ & $\ldots$ & .. & .. & .. & $0.36 \mathrm{I}$ \\
\hline & 4. iv & 64 & 5 & 52 & 7 & $\ldots$ & .. & $\ldots$ & .. & . & 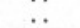 & $\because$ & 0.370 \\
\hline & 10. iv & 53 & 5 & 40 & 8 & .. & .. & $\because$ & $\because$ & $\therefore$ & $\because$ & $\because$ & 0.367 \\
\hline & I7. iv & 72 & $\therefore$ & 54 & 17 & I & $\because$. & $\because$. & $\because$. & $\because$ & $\because$. & $\because$. & 0.376 \\
\hline & 24. iv & 63 & . & 49 & 14 & .. & $\therefore$ & $\therefore$ & .. & .. & .. & . & 0.375 \\
\hline & I. v & 79 & I & 56 & 22 & .. & $\cdots$ & $\cdots$ & $\cdots$ & .. & .. & $\ldots$ & 0.375 \\
\hline & 8. v & 75 & 4 & 66 & 5 & .. & .. & .. & $\ldots$ & $\ldots$ & $\ldots$ & $\ldots$ & 0.369 \\
\hline & $15 . \mathrm{v}$ & 50 & 8 & 40 & 2 & .. & $\ldots$ & $\ldots$ & $\ldots$ & $\ldots$ & $\ldots$ & .. & 0.358 \\
\hline & 22. v. & 24 & 2 & 20 & 2 & $\ldots$ & $\ldots$ & . & $\ldots$ & $\ldots$ & $\ldots$ & .. & 0.369 \\
\hline & 5. vi & $4 \mathrm{I}$ & 3 & 35 & 3 & .. & .. & $\ldots$ & $\ldots$ & .. & .. & .. & 0.362 \\
\hline & I2. vi & 57 & 4 & 47 & 6 & .. & .. & .. & $\ldots$ & . & $\ldots$ & .. & 0.367 \\
\hline & I9. vi & 36 & 7 & 28 & I & .. & . & .. & $\ldots$ & $\ldots$ & $\ldots$ & .. & 0.359 \\
\hline & 26. vi & 67 & 35 & 32 & .. & $\ldots$ & $\ldots$ & $\cdots$ & $\ldots$ & $\ldots$ & $\cdots$ & . & 0.348 \\
\hline & 3. vii & 56 & 29 & 27 & .. & .. & .. & $\cdots$ & .. & .. & .. & $\cdots$ & 0.348 \\
\hline & Io. vii & 82 & $4 \mathrm{I}$ & $4 \mathrm{I}$ & $\cdots$ & $\cdots$ & .. & $\ldots$ & . & .. & $\ldots$ & .. & 0.348 \\
\hline & 17. vii & $6 \mathrm{I}$ & 19 & 40 & 2 & $\ldots$ & $\ldots$ & $\ldots$ & .. & $\ldots$ & $\ldots$ & $\ldots$ & 0.357 \\
\hline & 24. vii & 22 & 13 & 9 & .. & . & . & . & .. & . & $\ldots$ & .. & 0.346 \\
\hline & 3i. vii & 35 & 19 & 16 & .. & .. & .. & .. & .. & .. & .. & .. & 0.347 \\
\hline & 7. viii & 17 & 7 & IO & .. & . & .. & $\ldots$ & .. & $\therefore$ & $\therefore$ & 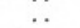 & 0.352 \\
\hline
\end{tabular}


Table XIII. Size of Centropages hamatus in mM.

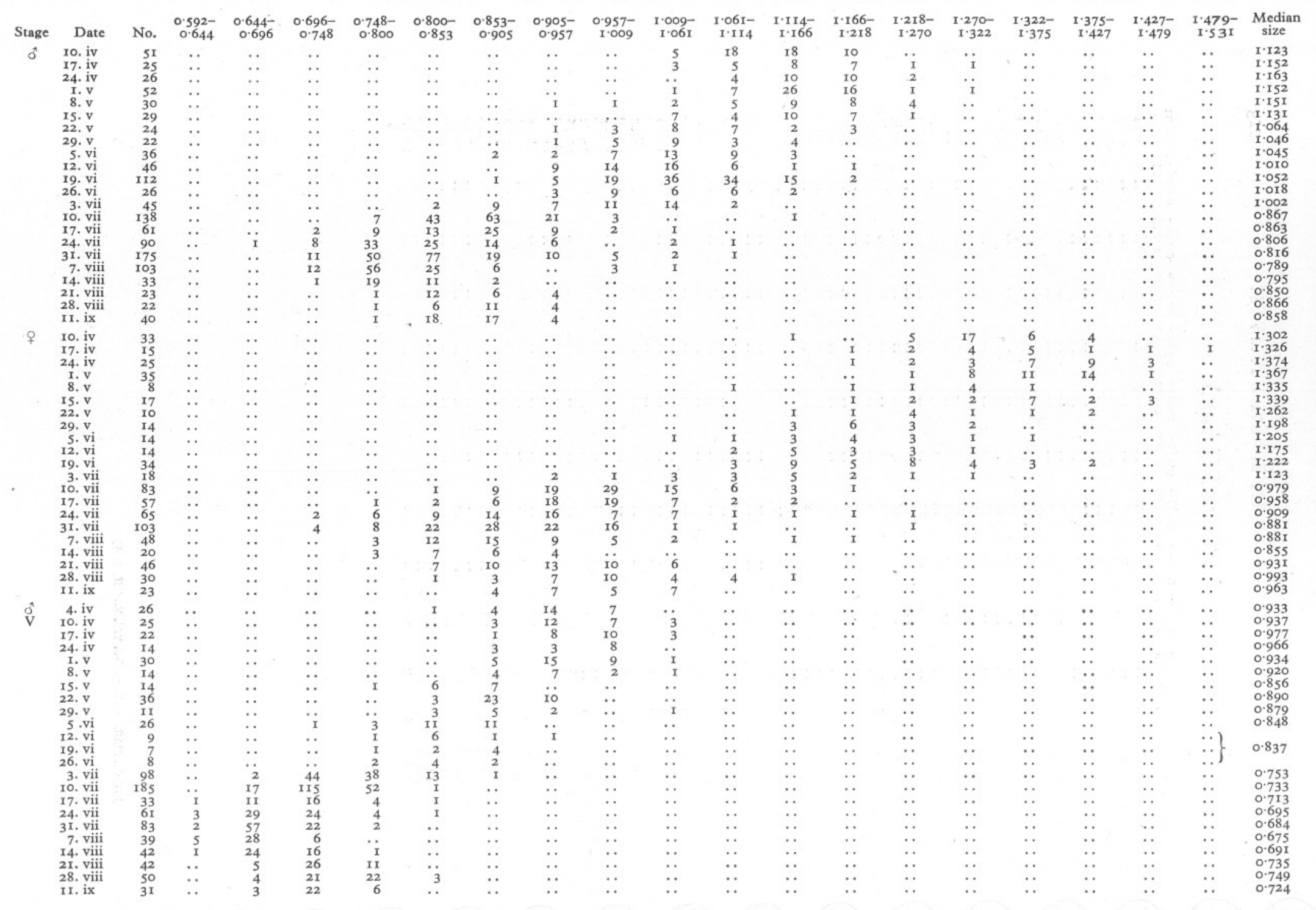




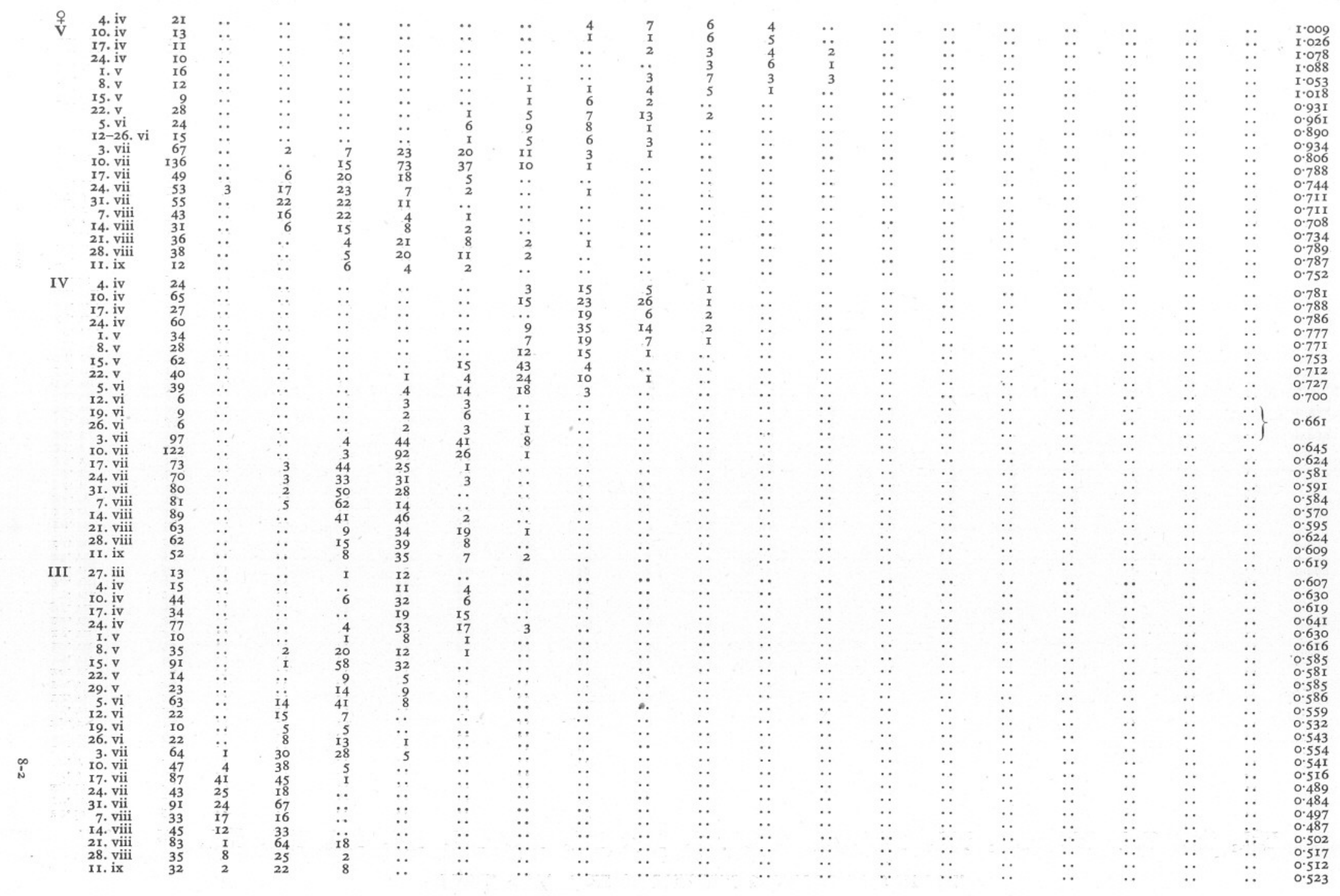


TABle XIV. Size of TEMORA LONGICORNIS IN MM.

\begin{tabular}{|c|c|c|c|c|c|c|c|c|c|c|c|c|c|c|c|c|c|c|c|c|c|}
\hline Stage & Date & No. & $\begin{array}{r}0.383- \\
0.435\end{array}$ & $\begin{array}{r}0.435- \\
0.487\end{array}$ & $\begin{array}{r}0.487- \\
0.539\end{array}$ & $\begin{array}{r}0.539- \\
0.592\end{array}$ & $\begin{array}{r}0.592- \\
0.644\end{array}$ & $\begin{array}{c}0.644- \\
0.696\end{array}$ & $\begin{array}{c}0.696- \\
0.748\end{array}$ & $\begin{array}{r}0.748- \\
0.800\end{array}$ & $\begin{array}{c}0.800- \\
0.853\end{array}$ & $\begin{array}{r}0.853- \\
0.905\end{array}$ & $\begin{array}{c}0.905- \\
0.957\end{array}$ & $\begin{array}{c}0.957- \\
\text { I.009 }\end{array}$ & $\begin{array}{l}\mathrm{I} .009- \\
\mathrm{I} \cdot 06 \mathrm{I}\end{array}$ & $\begin{array}{l}\text { I'06I- } \\
\text { I'II4 }\end{array}$ & $\begin{array}{l}I \cdot I 14- \\
I \cdot I 66\end{array}$ & $\begin{array}{l}\mathrm{I} \cdot \mathrm{I} 66- \\
\mathrm{I} \cdot 2 \mathrm{I} 8\end{array}$ & $\begin{array}{l}\text { I.218- } \\
\text { I. } 270\end{array}$ & $\begin{array}{r}1 \cdot 270- \\
1=322\end{array}$ & $\begin{array}{c}\text { Median } \\
\text { size }\end{array}$ \\
\hline \multirow[t]{19}{*}{0} & $\begin{array}{l}\text { xo. iv } \\
\text { x., iv }\end{array}$ & 92 & .. & . & $\because$ &.. & . & 2 & 8 & 17 & $3 I$ & 17 & 7 & 6 & 3 & I & .. & .. & .. & $\cdots$ & 0.837 \\
\hline & $\begin{array}{l}\text { 17. iv } \\
24 \text {. iv }\end{array}$ & $\begin{array}{l}24 \\
24\end{array}$ & $\because$. & $\because$. & $\because$. & $\because$ & $\because$. & I & . & 2 & $I$ & I0 & 6 & 2 & I & I & $\because$ & $\cdots$ & $\cdots$ & $\cdots$ & 0.898 \\
\hline & I. v & $\begin{array}{l}24 \\
59\end{array}$ & $\because$. & $\therefore$ & $\because$. & $\because$ & $\ddot{x}$ & & $\ddot{2}$ & $\begin{array}{l}2 \\
6\end{array}$ & 2 & $\begin{array}{l}6 \\
9\end{array}$ & $\begin{array}{r}3 \\
18\end{array}$ & 6 & 3 & $\begin{array}{l}1 \\
2\end{array}$ & I & $\because$ & $\because$ & 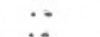 & $\begin{array}{l}0.937 \\
0.919\end{array}$ \\
\hline & $8 . \mathrm{v}$ & 88 & $\ldots$ & .. & $\ldots$ &.. & $\because$ & $\ddot{x}$ &.. & $\begin{array}{l}0 \\
3\end{array}$ & $\begin{array}{r}9 \\
14\end{array}$ & $\begin{array}{r}9 \\
34\end{array}$ & $\begin{array}{l}18 \\
25\end{array}$ & $\begin{array}{l}5 \\
6\end{array}$ & $\begin{array}{l}8 \\
I\end{array}$ & $\begin{array}{l}2 \\
4\end{array}$ & $\because$. & $\because$. & $\ddot{I}$ & $\because$ & $\begin{array}{l}0.919 \\
0.895\end{array}$ \\
\hline & $15 . \mathrm{v}$ & $2 I$ & $\therefore$ &.. &.. & . & .. & $\because$ & .. & $\vec{I}$ & 8 & 5 & 4 & I & .. & $\begin{array}{l}4 \\
1\end{array}$ & $\ddot{I}$ & $\because$. & .. & $\therefore$ & $\begin{array}{l}0.895 \\
0.887\end{array}$ \\
\hline & $22 . \mathrm{v}$ & $6 \mathrm{I}$ & $\because$ & .. &.. & . & .. & 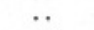 & 2 & 13 & 18 & 13 & 9 & 4 & $\because$ & $\ldots$ & I & I & $\cdots$ & $\cdots$ & $\begin{array}{l}0.887 \\
0.847\end{array}$ \\
\hline & $29 . \mathrm{v}$. & 14 & $\because$ & $\therefore$ & $\therefore$ & $\therefore$ & $\ldots$ & . & I & 3 & 3 & 3 & 2 & .. & 2 & $\cdots$ & .. & .. & . & $\cdots$ & $\begin{array}{l}0.862 \\
0.862\end{array}$ \\
\hline & 5. vi & 29 & $\therefore$ & $\therefore$ & . &.. & . & I & 6 & 7 & II & 4 &.. & . & .. & .. & .. & .. & $\cdots$ & $\cdots$ & 0.803 \\
\hline & 12. vi & 15 & $\because$ & 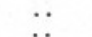 & $\because$ & $\because$ & $\because$ & $\because$ & 7 & $\begin{array}{l}6 \\
5\end{array}$ & $\begin{array}{l}2 \\
3\end{array}$ & $\ddot{3}$ & $\ddot{3}$ & $\ddot{2}$ & $\because$. & $\because$ & $\because$. & $\ddot{i}$ & $\because$ & $\because$ & $\begin{array}{l}0.754 \\
0.803\end{array}$ \\
\hline & $\begin{array}{l}\text { 19. vi } \\
\text { 26. vi }\end{array}$ & $\begin{array}{r}24 \\
8\end{array}$ & $\because$. & $\because$ & $\because$ & $\because$. & $\because$ & $\because$ & $\begin{array}{l}7 \\
3\end{array}$ & $\begin{array}{l}5 \\
5\end{array}$ & $\begin{array}{l}3 \\
. .\end{array}$ & $\therefore$ & & .. & $\ddot{x}$ & $\because$ & $\because$ & $\begin{array}{l}1 \\
.\end{array}$ & $\because$. & $\because$ & $\begin{array}{c}0.803 \\
\cdots\end{array}$ \\
\hline & 3. vii & 69 & $\because$. & $\because$. & $\because$. & $\because$. & $\ddot{8}$ & I4 & $3 \mathrm{I}$ & II & 3 & 2 & $\therefore$ & . & . & $\cdots$ & .. & $\cdots$ & $\cdots$ & $\cdots$ & 0.716 \\
\hline & Io, vii & 72 & .. & . & $\ldots$ & 2 & 20 & 37 & 7 & 5 &.. & $\ldots$ & I & .. & .. & . & .. & .. & $\cdots$ & $\cdots$ & 0.657 \\
\hline & 17. vii & 26 & $\therefore$ & $\therefore$ & . & 6 & I4 & 6 & $\because$ & $\because$ & $\because$ & .. & .. & . & .. & .. & $\cdots$ & $\cdots$ & $\cdots$ & $\cdots$ & $\begin{array}{l}0.625 \\
0.630\end{array}$ \\
\hline & 24. vii & $4 \mathrm{I}$ & $\because$ & $\therefore$ & $\because$ & 12 & 12 & 7 & 6 & 2 & 2 & .. & .. & .. & . & $\cdots$ & . & . & $\because$ & & $\begin{array}{l}0.630 \\
0.591\end{array}$ \\
\hline & 31. vii & 56 & $\because$ & $\because$. & $\begin{array}{l}2 \\
1\end{array}$ & 27 & $2 I$ & 6 & $\ddot{I}$ & $\because$ & . & . & . & .. & $\because$ & .. & . & $\because$ & . & $\because$ & $\begin{array}{l}0.591 \\
0.597\end{array}$ \\
\hline & $\begin{array}{l}\text { 7. viii } \\
\text { 14. viii }\end{array}$ & $\begin{array}{l}77 \\
44\end{array}$ & $\because$. & $\because$ & $\begin{array}{l}\mathbf{I} \\
\mathbf{I}\end{array}$ & $\begin{array}{l}33 \\
14\end{array}$ & $\begin{array}{l}32 \\
26\end{array}$ & $\begin{array}{l}9 \\
3\end{array}$ & $\begin{array}{l}I \\
. .\end{array}$ & r & $\because$ & $\because$ & $\because$. & $\because$. & $\because$. & $\because$. & $\because$ & $\because$ & $\because$ & $\therefore$ & $\begin{array}{l}0.597 \\
0.601\end{array}$ \\
\hline & 2I. viii & 68 & $\because$. & $\because$ & .. & $I$ & 22 & $3 \mathrm{I}$ & ï 3 & $\ddot{\mathbf{i}}$ & $\because$. & $\because$. & $\because$. & $\because$. & $\because$. & $\because$ & $\because$. & $\because$. & $\because$. & $\therefore$ & $\begin{array}{l}0.001 \\
0.669\end{array}$ \\
\hline & 28, viii & $5 \mathrm{I}$ & $\therefore$ & $\ldots$ & . & .. & II & 23 & 12 & 3 & 2 & .. & .. & .. & .. & .. & .. & .. & .. & . & 0.678 \\
\hline & II. ix & 54 & $\because$ &.. & .. & 9 & 23 & 15 & 7 & .. & .. & .. & $\cdots$ & .. & .. & . & . & . & $\cdots$ & $\cdots$ & 0.635 \\
\hline \multirow{19}{*}{ 우 } & Io. iv & 85 & .. & .. & $\therefore$ & .. & .. & I & 3 & 2 & 12 & $2 \mathrm{I}$ & II & 9 & ro & I0 & 3 & 3 & .. & $\ldots$ & 0.922 \\
\hline & 17. iv & 25 & & $\ldots$ & . & $\cdots$ & .. & .. &. & .. & .. & 3 & I & 6 & 4 & 3 & 5 & 2 & I & $\cdots$ & 1.036 \\
\hline & 24 . iv & 13 & .. & $\cdots$ & $\ldots$ & $\cdots$ & $\cdots$ & .. & .. & $\cdots$ & $\because$ & I & I & I & 3 & 3 & 3 & I & $\cdots$ & $\because$ & I. 067 \\
\hline & $\mathrm{I} . \mathrm{v}$ & 33 & $\because$ & . & .. & . & $\ldots$ & .. & .. & .. & 5 & 3 & 9 & 5 & 3 & 5 & I & I & $\because$ & $\mathbf{I}$ & $\begin{array}{l}0.957 \\
0.960\end{array}$ \\
\hline & 8. v & 60 & $\because$ & $\because$ & . & $\cdots$ & .. & .. & $\because$ & . & 7 & I0 & 13 & 13 & 8 & 3 & 3 & 2 & I & $\cdots$ & 0.960 \\
\hline & 15. v & Io & $\because$. & $\because$. & $\because$ & . & .. & .. & I & $\because$ & $\ddot{6}$ & ${ }_{5}^{I}$ & $\because$ & 4 & 2 & I & I & .. & $\cdots$ & $\cdots$ & $\begin{array}{l}1.001 \\
050\end{array}$ \\
\hline & & $\begin{array}{l}21 \\
14\end{array}$ & $\because$ & $\because$. & $\because$. & $\because$ & . & . & $\because$ & $\begin{array}{l}5 \\
2\end{array}$ & $\begin{array}{l}6 \\
6\end{array}$ & 5 & 2 & I & . & I & I & .. & $\cdots$ & $\cdots$ & 0.852 \\
\hline & $\begin{array}{l}\text { 29. v } \\
5 . \mathrm{vi}\end{array}$ & $\begin{array}{l}14 \\
13\end{array}$ & .. & $\because$. & $\because$. & $\because$. & $\because$ & $\because$ & I & $\begin{array}{l}2 \\
4\end{array}$ & $\begin{array}{l}6 \\
3\end{array}$ & $\because$ & 3 & 2 & $\because$ & $\because$ & $\therefore$ & $\because$. & $\because$ & $\because$ & $\begin{array}{l}0.839 \\
0.817\end{array}$ \\
\hline & $\begin{array}{l}\text { 5. v1 } \\
\text { I9. vi }\end{array}$ & $\begin{array}{l}13 \\
23\end{array}$ & .. & $\therefore$ & $\because$ & $\because$. & $\because$ & $\begin{array}{l}\mathrm{I} \\
.\end{array}$ & $\begin{array}{l}\mathrm{I} \\
\mathrm{I}\end{array}$ & $\begin{array}{l}4 \\
5\end{array}$ & $\begin{array}{l}3 \\
7\end{array}$ & $\ddot{3}$ & & $\ddot{I}$ & $\because$ & $\because$ & $\because$ & 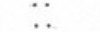 & $\because$ & $\therefore$ & $\begin{array}{l}0.817 \\
0.844\end{array}$ \\
\hline & 3. vii & 37 & $\ldots$ & $\ldots$ & . & $\therefore$ & $\ddot{I}$ & $\dddot{5}$ & II & 9 & 8 & $\frac{3}{2}$ &.. & $\mathrm{I}$ & $\because$. & $\because$ & $\because$. & $\because$ & $\because$. & $\therefore$ & $\begin{array}{l}0.844 \\
0.757\end{array}$ \\
\hline & I0. vii & 57 & $\ldots$ & . & . & 2 & 7 & 22 & 17 & 5 & 3 & 2 & .. & .. & $\cdots$ & . & $\cdots$ & . & . & $\ldots$ & 0.693 \\
\hline & 17. vii & 13 & $\ldots$ & .. & .. & I & 8 & 4 & 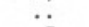 &. & $\cdots$ & $\cdots$ & .. & .. & .. & $\cdots$ & $\cdots$ & $\cdots$ & .. & $\cdots$ & 0.632 \\
\hline & 24. vii & 26 & $\ldots$ & . & 2 & 3 & I0 & 7 & I & 3 & $\cdots$ & .. & . & . & . & $\cdots$ & $\cdots$ & $\cdots$ & . & $\cdots$ & 0.630 \\
\hline & 3I. vii & 35 & .. & $\ldots$ & 3 & 9 & 15 & 8 & .. &. & .. & .. & $\cdots$ & .. & . & $\cdots$ & $\cdots$ & $\cdots$ & . & $\cdots$ & 0.6 II \\
\hline & 7. viii & 64 & $\ldots$ & . & I & 22 & 29 & 10 & I & I & $\cdots$ & . & . & .. & $\cdots$ & . & $\cdots$ & $\cdots$ & . & $\cdots$ & 0.604 \\
\hline & I4. viii & 56 & . & .. & I & 18 & 27 & 9 & I & .. & $\because$ & . & .. & .. & . & $\cdots$ & $\cdots$ & $\cdots$ & . & $\cdots$ & 0.615 \\
\hline & 2I. viii & 80 & $\ldots$ & 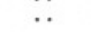 & $\ldots$ & 5 & 27 & 29 & 12 & 5 & 2 & .. & .. & .. & . & $\cdots$ & . & $\cdots$ & $\cdots$ & $\cdots$ & 0.657 \\
\hline & 28. viii & 58 &.. & . &.. & $\because$ & I & 22 & 18 & I5 & 2 & .. & .. & . & $\cdots$ & . & $\cdots$ & $\cdots$ & $\cdots$ & $\cdots$ & $\begin{array}{l}0.709 \\
0.638\end{array}$ \\
\hline & II. ix & 32 & $\ldots$ & . & . & 6 & 12 & 9 & 5 & $\cdots$ & $\cdots$ & . & .. & . & $\cdots$ & $\cdots$ & . & . & $\cdots$ & $\cdots$ & 0.638 \\
\hline \multirow{18}{*}{$\stackrel{0}{\mathrm{~V}}$} & Io. iv & 55 & .. & .. & .. & .. & $I$ & 3 & 20 & 17 & $\mathrm{I} 2$ & 2 & $\ldots$ & .. & .. & .. & .. & .. & .. & $\cdots$ & 0.758 \\
\hline & I7. iv & & $\therefore$ & . & $\ldots$ & $\cdots$ & $\ldots$ & .. & I & 4 & 6 & $\because$ & I & $\cdots$ & $\cdots$ & . & . & $\cdots$ & $\cdots$ & $\cdots$ & $\begin{array}{l}0.809 \\
0.89\end{array}$ \\
\hline & 24 . iv & 10 & 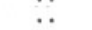 & . & $\ldots$ & .. & . & $\because$ & 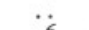 & 7 & I & 2 & .. & . & $\cdots$ & . & . & .. & .. & $\cdots$ & $0.78 \mathrm{r}$ \\
\hline & I. v & 25 & $\therefore$ & $\ldots$ & $\ldots$ & $\cdots$ & $\cdots$ & I & 6 & II & 7 & .. & .. & $\cdots$ & .. & $\cdots$ & $\cdots$ & $\cdots$ & $\cdots$ & $\cdots$ & $\begin{array}{l}0.772 \\
0.76\end{array}$ \\
\hline & $8 . \mathrm{v}$ & $4 \mathrm{I}$ & $\ldots$ & $\ldots$ & $\ldots$ & $\ldots$ & I & 4 & 17 & 14 & 5 & $\cdots$ & .. & .. & . & . & . & . & $\cdots$ & $\cdots$ & $\begin{array}{l}0.746 \\
0.67\end{array}$ \\
\hline & 22. v & 13 & $\ldots$ & $\ldots$ & $\ldots$ & $\cdots$ & 4 & 8 & I & $\ldots$ & & .. & . & . &.. & . & .. & $\cdots$ & $\cdots$ & $\cdots$ & 0.657 \\
\hline & 5. vi & 16 & $\therefore$ & $\ldots$ & $\therefore$ & 3 & 4 & 7 & 2 & .. & . & .. & .. & .. & . & . & . & $\cdots$ & .. & $\cdots$ & 0.657 \\
\hline & 19. vi & 17 & $\therefore$ & $\ldots$ & $\ldots$ & I & 8 & 4 & 4 & $\cdots$ & .. & . & . & $\ldots$ & $\ldots$ & .. & .. & $\cdots$ & $\cdots$ & $\cdots$ & 0.643 \\
\hline & 3. vii & 66 & $\because$ & $\ldots$ & 7 & 25 & $2 I$ & 7 & 5 & I & . & $\ldots$ & $\ldots$ & . & $\cdots$ & . & .. & .. & .. & . & 0.594 \\
\hline & I0. vii & 26 & $\therefore$ & $\ldots$ & 5 & Io & I0 & I & $\ldots$ & $\cdots$ & . & . &.. & . & . & .. & .. & .. & . & $\cdots$ & 0.578 \\
\hline & 17. vii & 24 & $\because$. & 2 & II & II & .. &.. & .. & .. & .. & .. & .. & .. & .. & . & . & .. & $\cdots$ & $\cdots$ & 0.537 \\
\hline & 24. vii & 15 & $\because$. & 5 & 7 & 2 & I & .. & .. & .. & .. & .. & . & .. & .. & . & .. & $\ldots$ & $\cdots$ & $\cdots$ & 0.504 \\
\hline & 3I. vii & 24 & . & 2 & 12 & 10 & $\ldots$ & . & $\ldots$ & .. & .. & $\cdots$ & .. & .. & .. & . & $\cdots$ & $\cdots$ & $\cdots$ & . & 0.533 \\
\hline & 7. viii & 60 & $\because$ & I & 48 & II & . & $\ldots$ & $\ldots$ & $\ldots$ & . & 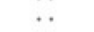 &.. & $\ldots$ & $\ldots$ & .. & $\ldots$ & $\ldots$ & . & $\cdots$ & 0.516 \\
\hline & I4. viii & 47 & $\ldots$ & 2 & 32 & 13 & . & $\ldots$ & $\ldots$ & $\ldots$ & .. & .. & .. & .. & .. & .. & $\cdots$ & $\cdots$ & .. & $\cdots$ & 0.522 \\
\hline & 21. viii & 40 & . & .. & 4 & 24 & II & .. & I & $\ldots$ & $\ldots$ & $\ldots$ & .. & .. & $\cdots$ & .. & $\cdots$ & $\cdots$ & . & . & 0.575 \\
\hline & 28. viii & 13 & $\because$. & $\therefore$ &.. & 8 & 4 & I & $\cdots$ & .. & .. & $\cdots$ & $\cdots$ & .. & $\cdots$ & . & $\cdots$ & $\cdots$ & $\cdots$ & . & 0.586 \\
\hline & II. ix & 13 & $\because$. & 2 & 7 & 4 & , & ., & $\ldots$ & . & . & .. &.. &.. & $\cdots$ & $\cdots$ & .. & .. & .. & $\cdots$ & 0.522 \\
\hline
\end{tabular}




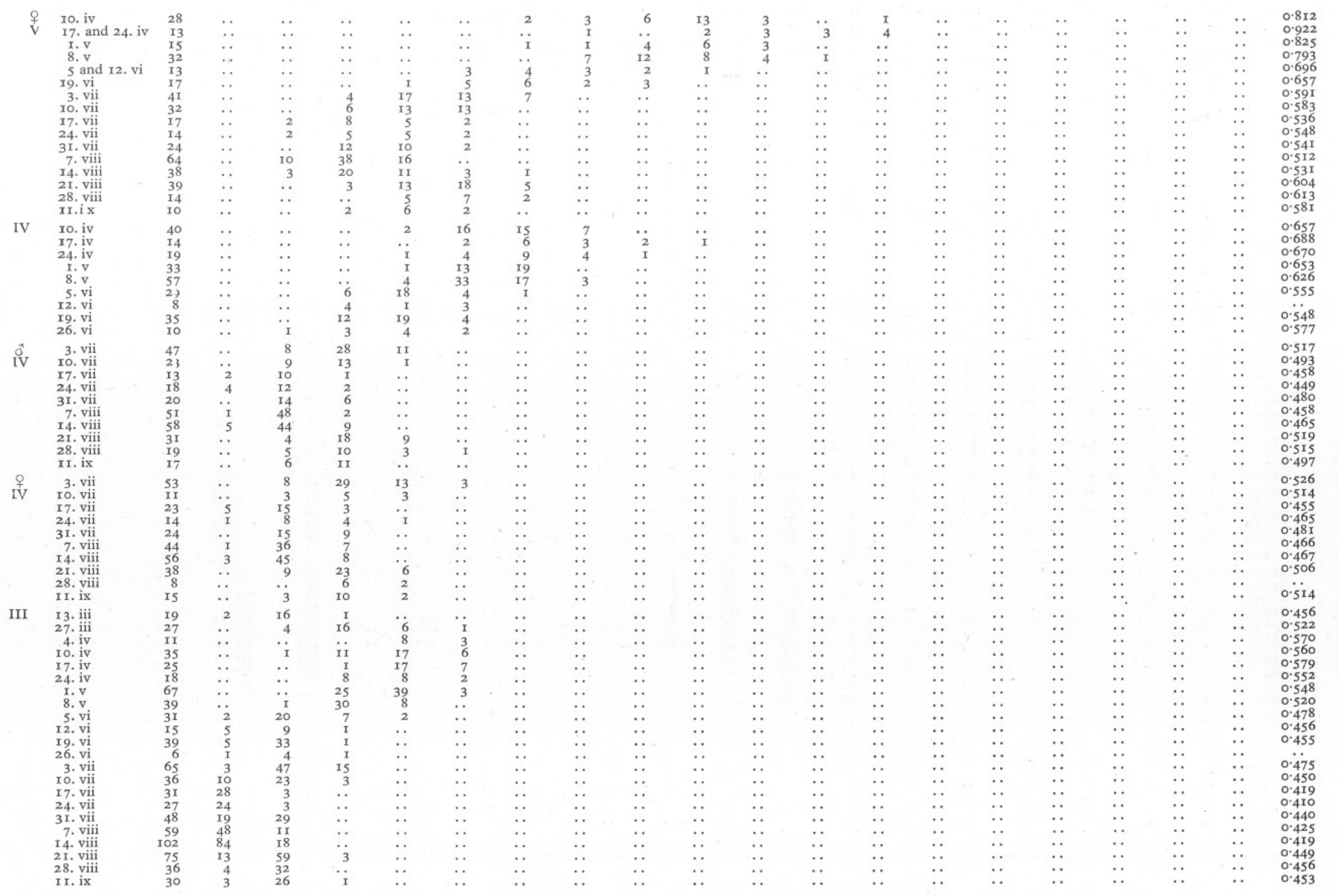


Table XV. Size of Acartia ClaUSi in mm.

\begin{tabular}{|c|c|c|c|c|c|c|c|c|c|c|c|c|c|c|c|c|c|c|}
\hline Stage & Date & No. & $\begin{array}{r}0.487- \\
0.539\end{array}$ & $\begin{array}{r}0.539- \\
0.592\end{array}$ & $\begin{array}{c}0.592- \\
0.644\end{array}$ & $\begin{array}{r}0.644- \\
0.696\end{array}$ & $\begin{array}{r}0.696- \\
0.748\end{array}$ & $\begin{array}{r}0.748- \\
0.800\end{array}$ & $\begin{array}{r}0.800- \\
0.853\end{array}$ & $\begin{array}{r}0.853- \\
0.905\end{array}$ & $\begin{array}{r}0.905- \\
0.957\end{array}$ & $\begin{array}{r}0.957- \\
1.009\end{array}$ & $\begin{array}{r}1 \cdot 009- \\
1.061\end{array}$ & $\begin{array}{r}\text { I.06I- } \\
\text { I'II4 }\end{array}$ & $\begin{array}{r}I \cdot I \times 4- \\
I \cdot I 66\end{array}$ & $\begin{array}{r}x \cdot 166- \\
I \cdot 218\end{array}$ & $\begin{array}{r}1 \cdot 218- \\
I .270\end{array}$ & $\begin{array}{c}\text { Median } \\
\text { size }\end{array}$ \\
\hline \multirow[t]{20}{*}{ 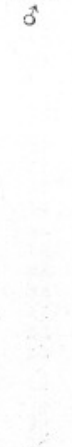 } & $\begin{array}{l}\text { 24. iv } \\
\text { I. } v\end{array}$ & & $\therefore$ & $\because$ & . & . & . & $\because$ & $\ddot{x}$ & . & $\because$ & 21 & 4 & $\cdots$ & $\cdots$ & $\cdots$ & $\cdots$ & 0.987 \\
\hline & $\begin{array}{l}\mathrm{I} . \mathrm{v} \\
8 . \mathrm{v}\end{array}$ & $\begin{array}{l}24 \\
35\end{array}$ & $\because$ & $\ddot{z}$ & 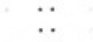 & $\because$ & & $\because$. & $\because$ & $\because$ & $\begin{array}{l}2 \\
7\end{array}$ & $\begin{array}{l}15 \\
18\end{array}$ & $\begin{array}{r}7 \\
10\end{array}$ & $\because$. & $\because$. & $\because$ & $\because$ & \\
\hline & $15 . \mathrm{V}$ & 10 & & .. & . & 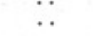 & $\because$ & $\ddot{I}$ & $\because$ & $\because$ & $\begin{array}{l}7 \\
4\end{array}$ & 5 & $\begin{array}{l}10 \\
\cdots\end{array}$ & $\because$. & $\because$ & $\because$. & 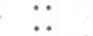 & $\begin{array}{l}0.994 \\
0.959\end{array}$ \\
\hline & 22. v & $4 \mathrm{I}$ & .. & . & . & $\ldots$ & .. & . & $\cdots$ & I & 21 & I8 & $\ddot{I}$ & $\because$ & $\because$ & $\therefore$ & $\because$ & $\begin{array}{l}0.959 \\
0.955\end{array}$ \\
\hline & 29. v & 13 & . & . & $\cdots$ & $\cdots$ & $\cdots$ & . & .. & $\cdots$ & I0 & 2 & I & . & .. & $\cdots$ & .. & 0.939 \\
\hline & 5. vi & 15 & . & $\cdots$ & . & $\cdots$ & $\cdots$ & $\cdots$ & $\because$ & 3 & 9 & 3 & $\cdots$ & . & .. & .. & .. & 0.934 \\
\hline & I2. vi & $5 \mathrm{I}$ & . & .. & . & $\cdots$ & . & . & I & 33 & I5 & 2 & .. & $\cdots$ & .. & $\cdots$ & $\cdots$ & 0.893 \\
\hline & I9. vi & 68 & .. & . & $\because$ & . & . & $\cdots$ & I & 31 & 33 & 3 & $\cdots$ & $\cdots$ & $\cdots$ & $\cdots$ & $\cdots$ & 0.907 \\
\hline & 26. vi & 80 & $\cdots$ & $\cdots$ & $\cdots$ & $\cdots$ & $\cdots$ & $\cdots$ & 2 & 63 & 14 & I & .. & . & . & $\cdots$ & . & 0.889 \\
\hline & 3. vii & I 64 & $\cdots$ & $\cdots$ & . & $\cdots$ & $\cdots$ & $\cdots$ & 12 & . 132 & 20 & $\because$ & . & $\cdots$ & $\cdots$ & $\cdots$ & $\cdots$ & 0.885 \\
\hline & Io. vii & 134 & .. & . & $\cdots$ & . & $\cdots$ & . & 6 & 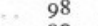 & 29 & I & $\cdots$ & $\cdots$ & . & $\cdots$ & $\cdots$ & 0.887 \\
\hline & I7. vii & I39 & .. & .. & .. & .. & . & . & 37 & 90 & 12 & $\cdots$ & $\cdots$ & $\cdots$ & $\cdots$ & $\cdots$ & $\cdots$ & 0.866 \\
\hline & 24. vii & 104 & .. & $\cdots$ & . & . & . & 2 & 50 & 48 & 4 & $\cdots$ & .. & .. & .. & $\cdots$ & . & 0.853 \\
\hline & 3I. vii & 131 & $\cdots$ & $\cdots$ & $\cdots$ & $\cdots$ & $\cdots$ & 4 & 95 & 29 & 3 & $\cdots$ & . & . & $\cdots$ & $\cdots$ & $\cdots$ & 0.833 \\
\hline & 7. viii & IOI & . & $\cdots$ & .. & $\cdots$ & . & 10 & 79 & II & $\mathbf{I}$ & $\cdots$ & $\cdots$ & $\cdots$ & . & $\cdots$ & $\cdots$ & 0.827 \\
\hline & I4. viii & 77 & .. & .. & . & .. & $\cdots$ & 13 & 62 & 2 & . & $\cdots$ & $\cdots$ & $\cdots$ & $\cdots$ & . & . & 0.819 \\
\hline & 2r. viii & 89 & .. & .. & I & .. & .. & 9 & $7 \mathrm{I}$ & 8 & .. & $\cdots$ & .. & . & $\cdots$ & $\cdots$ & $\cdots$ & 0.828 \\
\hline & 28. viii & 84 & . & $\cdots$ & $\cdots$ & . & $\cdots$ & 3 & 72 & 9 & $\cdots$ & $\cdots$ & . & .. & .. & $\cdots$ & $\cdots$ & 0.833 \\
\hline & Ir. ix & $80^{\circ}$ & $\cdots$ & .. & .. & .. & $\cdots$ & 4 & 70 & 6 & $\cdots$ & $\cdots$ & $\cdots$ & .. & $\cdots$ & . & . & 0.828 \\
\hline & 2. $x$ & 103 & . & . & .. & . & .. & I & 58 & 44 & $\cdots$ & $\cdots$ & $\cdots$ & $\cdots$ & $\cdots$ & $\cdots$ & $\cdots$ & 0.848 \\
\hline \multirow[t]{26}{*}{ 우 } & $17 . \mathrm{i}$ & 17 & . & .. & . & . & .. & I & 3 & 7 & 6 & .. & .. & $\cdots$ & .. & $\ldots$ & . & 0.870 \\
\hline & 23. i & 28 & .. & .. & I & .. & . & $I$ & 5 & I4 & 6 & I & $\cdots$ & & .. & $\cdots$ & . & 0.874 \\
\hline & 30. i & 13 & . & . & . & .. & .. & . & 3 & 9 & I & $\because$ & $\cdots$ & $\cdots$ & .. & $\ldots$ & . & 0.879 \\
\hline & 6. ii & 25 & .. & $\cdots$ & $\cdots$ & $\because$ & $\cdots$ & $\ldots$ & 5 & 15 & 4 & I & $\cdots$ & . & . & $\cdots$ & . & 0.882 \\
\hline & 13. ii & 13 & $\ldots$ & . & $\cdots$ & I & . & .. & 6 & 5 & .. & I & $\cdots$ & $\ldots$ & .. & $\ldots$ & .. & 0.853 \\
\hline & 24 . iv & 33 & .. & $\cdots$ & . & $\cdots$ & .. & $\cdots$ & $\cdots$ & I & . & .. & .. & I & I5 & I6 & .. & I. I 68 \\
\hline & I. V & 27 & .. & $\cdots$ & . & .. & .. & $\cdots$ & $\cdots$ & .. & I & I & $\cdots$ & 6 & 9 & 9 & I & $\mathrm{I} \cdot 148$ \\
\hline & 8. $\mathrm{v}$ & 28 & .. & .. & . & .. & .. & $\cdots$ & $\cdots$ & .. & $\ldots$ & .. & 3 & 8 & 9 & 8 & .. & I. 138 \\
\hline & I5. V & $2 \mathrm{I}$ & . & $\cdots$ & . & . & $\cdots$ & . & . & .. & .. & .. & 7 & 5 & 7 & 2 & .. & I. 105 \\
\hline & $22 . \mathrm{v}$ & 19 & .. & $\cdots$ & . & $\cdots$ & .. & . & $\cdots$ & I & $\ldots$ & .. & 3 & Io & 4 & I & .. & $\mathrm{I} .089$ \\
\hline & 29. v. & 35 & .. & .. & .. & $\cdots$ & $\cdots$ & $\cdots$ & $\cdots$ & $\cdots$ & $\cdots$ & 2 & II & 9 & 7 & 6 & . & $\mathrm{I} \cdot 076$ \\
\hline & 5. vi & 17 & .. & .. &. & .. & .. & .. & .. & .. & .. & 3 & 2 & 9 & 3 & .. & .. & 1.088 \\
\hline & I2. vi & 61 & $\cdots$ & . & . & . & . & . & .. & .. & .. & $\ddot{8}$ & 30 & I4 & 7 & 2 & .. & I.049 \\
\hline & 19. vi & 60 & $\cdots$ & $\cdots$ & $\cdots$ & .. & . & $\cdots$ & . & .. & .. & 25 & 30 & 4 & I & $\cdots$ & . & I.018 \\
\hline & 26. vi & 86 & $\ldots$ & .. & $\cdots$ & .. & $\ldots$ & $\cdots$ & . & .. & 4 & 38 & 37 & 6 & . & I & .. & I.OI I \\
\hline & 3. vii & $12 \mathrm{I}$ & .. & . & $\cdots$ & .. & .. & .. & .. & .. & 12 & 59 & 48 & I & I & $\cdots$ & .. & I. 004 \\
\hline & Io. vii & 126 & $\cdots$ & $\cdots$ & . & . & . & .. & . & . & 27 & 62 & 32 & 5 & .. & $\cdots$ & .. & 0.989 \\
\hline & 17. vii & Iro & . & .. & . & . & $\cdots$ & .. & . & 7 & 57 & 29 & 16 & I & . & . & . & 0.952 \\
\hline & 24. vii & II9 & $\cdots$ & .. & .. & .. & .. & .. & 4 & 38 & 52 & 20 & 5 & $\cdots$ & . & $\cdots$ & . & 0.919 \\
\hline & 3r. vii & 93 & $\cdots$ & . & .. & .. & .. & .. & II & 50 & 25 & 7 & .. & $\cdots$ & $\cdots$ & $\cdots$ & $\cdots$ & 0.895 \\
\hline & 7. viii & 108 & . & . & $\cdots$ & . & . & . & I0 & 71 & 24 & 3 & .. & $\ldots$ & $\ldots$ & .. & $\cdots$ & 0.885 \\
\hline & I4. viii & ro3 & $\cdots$ & .. & .. & $\cdots$ & . & . & 17 & 63 & 19 & 3 & I & 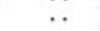 & . & . & . & 0.883 \\
\hline & 21. viii & 94 & .. & .. & .. & .. & . & I & 29 & 60 & 3 & I & .. & $\cdots$ & $\cdots$ & $\cdots$ & $\cdots$ & 0.887 \\
\hline & 28. viii & III & $\cdots$ & $\cdots$ & $\cdots$ & .. & .. & 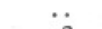 & 16 & 68 & 25 & 2 & .. & $\cdots$ & $\cdots$ & & $\cdots$ & 0.888 \\
\hline & II. ix & 9I & $\cdots$ & . & $\cdots$ & $\cdots$ & . & 2 & 15 & 53 & 21 & . & .. & $\ldots$ & .. & .. & $\cdots$ & 0.875 \\
\hline & $2 . x$ & 79 & .. & . & 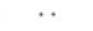 & $\cdots$ & $\cdots$ & I & 8 & 39 & 29 & 2 & . & $\cdots$ & $\cdots$ & . & .. & 0.894 \\
\hline$\hat{0}$ & 24. iv & 9 & .. & .. & $\ldots$ & $\ldots$ & .. & .. & I & 8 & .. & . & .. & $\ldots$ & .. & .. & . & $0.89 \mathrm{I}$ \\
\hline \multirow[t]{16}{*}{$\mathrm{V}$} & $22 . \mathrm{v}$ & 9 & $\cdots$ & .. & . & . & $\cdots$ & . & 7 & 2 & .. & .. & .. & $\cdots$ & $\cdots$ & .. & .. & 0.845 \\
\hline & 5. vi & 30 & $\cdots$ & . & $\cdots$ & $\ldots$ & $\because$ & 7 & 23 & . & . & . & . & $\cdots$ & $\cdots$ & . & $\cdots$ & 0.811 \\
\hline & I2. vi & 35 & .. & .. & $\ldots$ & .. & I & 16 & I5 & & I & $\cdots$ & . & $\cdots$ & $\cdots$ & $\cdots$ & $\cdots$ & 0.803 \\
\hline & I9. vi & 40 & . & .. & .. & .. & I & 28 & I I & $\cdots$ & $\ldots$ & $\cdots$ & $\cdots$ & $\cdots$ & .. & .. & $\cdots$ & 0.792 \\
\hline & 26. vi & 22 & $\cdots$ & $\cdots$ & .. & $\cdots$ & $\cdots$ & 7 & I5 & .. & $\ldots$ & .. & .. & $\cdots$ & $\ldots$ & .. & $\cdots$ & 0.810 \\
\hline & 3. vii & 48 & $\cdots$ & .. & $\cdots$ & $\ldots$ & I & 3 I & I6 & $\cdots$ & . & $\cdots$ & $\ldots$ & $\cdots$ & $\cdots$ & $\cdots$ & $\cdots$ & 0.792 \\
\hline & 10. vii & 124 & .. & $\ldots$ & $\ldots$ & $\cdots$ & 3 & 98 & 23 & $\cdots$ & $\cdots$ & $\cdots$ & . & $\cdots$ & $\cdots$ & $\cdots$ & . & 0.783 \\
\hline & 17. vii & 79 & $\cdots$ & . & $\cdots$ & $\ldots$ & 21 & 55 & 3 & . & .. & . & . & $\cdots$ & $\cdots$ & $\cdots$ & . & 0.760 \\
\hline & 24. vii & 72 & $\cdots$ & $\cdots$ & $\cdots$ & . & $3 \mathrm{I}$ & 39 & 2 & $\cdots$ & $\cdots$ & $\cdots$ & $\cdots$ & $\cdots$ & $\cdots$ & .. & $\cdots$ & 0.752 \\
\hline & 3r. vii & 73 & $\cdots$ & .. & $\cdots$ & .. & 38 & 35 & $\cdots$ & . & $\cdots$ & $\cdots$ & $\cdots$ & $\cdots$ & $\cdots$ & $\cdots$ & $\cdots$ & 0.748 \\
\hline & 7. viii & $6 \mathrm{I}$ & I & $\ldots$ & .. & $\cdots$ & 40 & 20 & $\cdots$ & $\cdots$ & $\cdots$ & . & $\cdots$ & .. & . & . & $\cdots$ & 0.738 \\
\hline & I4. viii & 51 & .. & .. & $\ldots$ & .. & 23 & 28 & $\ldots$ & .. & $\cdots$ & $\cdots$ & $\ldots$ & $\cdots$ & . & .. & $\cdots$ & 0.750 \\
\hline & 21. viii & 40 & $\cdots$ & .. & $\cdots$ & $\cdots$ & 10 & 30 & . & $\cdots$ & $\cdots$ & $\cdots$ & . & $\cdots$ & $\cdots$ & .. & .. & 0.760 \\
\hline & 28. viii & 87 & .. & .. & .. & .. & 20 & 66 & I & .. & $\cdots$ & $\cdots$ & $\cdots$ & .. & $\cdots$ & .. & . & 0.764 \\
\hline & II. ix & 60 & .. & .. & $\cdots$ & .. & I6 & 44 & 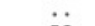 & .. & $\cdots$ & . & $\cdots$ & $\cdots$ & $\cdots$ & $\cdots$ & $\cdots$ & 0.759 \\
\hline & $2 . x$ & 66 & .. & .. & .. & .. & 4 & 52 & 10 & . & $\cdots$ & $\cdots$ & $\cdots$ & .. & $\cdots$ & $\cdots$ & $\cdots$ & 0.786 \\
\hline
\end{tabular}




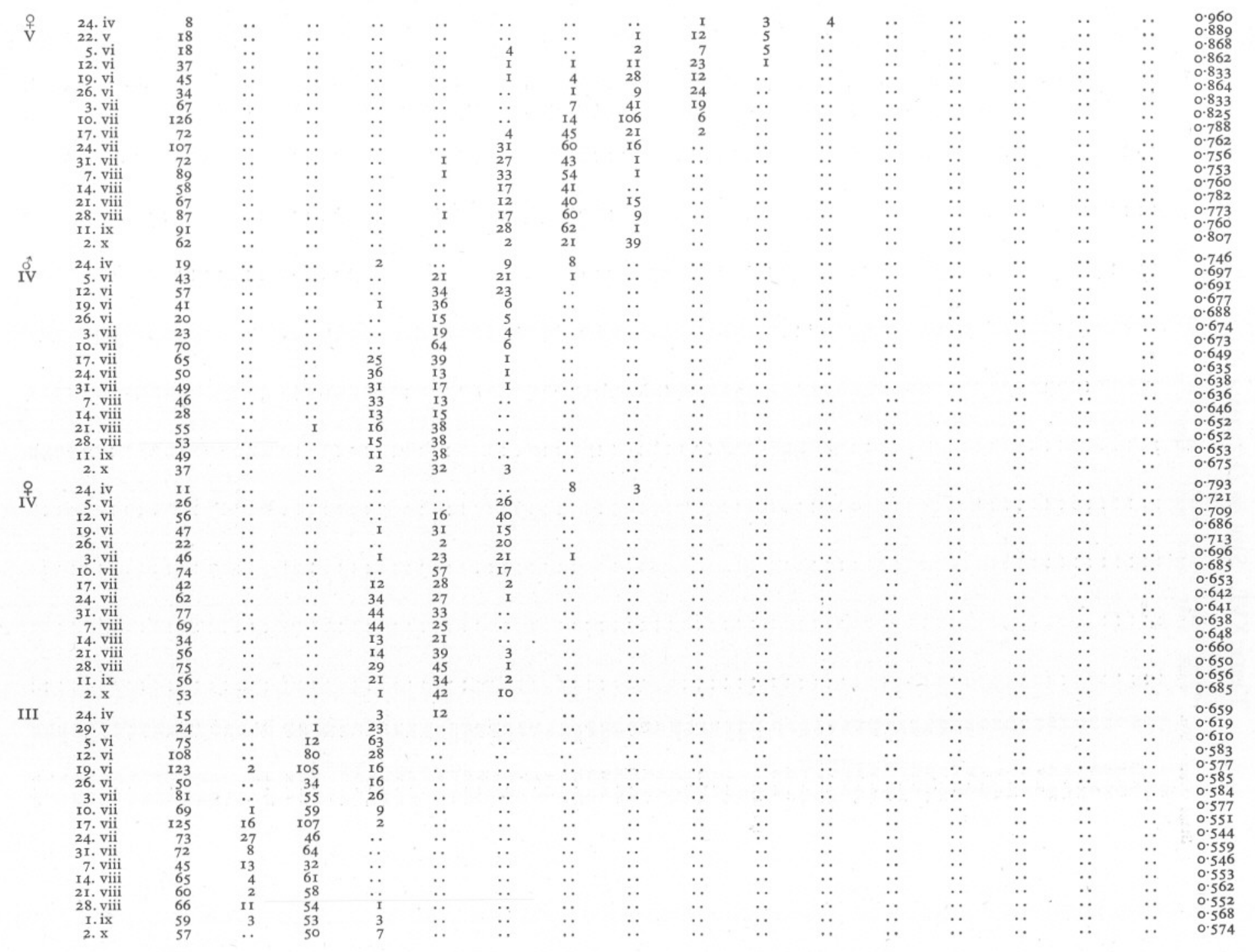


TABle XVI. Size of OITHONA SIMILIS IN MM.

\begin{tabular}{|c|c|c|c|c|c|c|c|c|c|c|c|c|c|}
\hline Stage & Date & No. & $\begin{array}{r}0.313- \\
0.348\end{array}$ & $\begin{array}{r}0.348- \\
0.383\end{array}$ & $\begin{array}{c}0.383- \\
0.418\end{array}$ & $\begin{array}{r}0.418- \\
0.452\end{array}$ & $\begin{array}{r}0.452- \\
0.487\end{array}$ & $\begin{array}{r}0.487- \\
0.522\end{array}$ & $\begin{array}{r}0.522- \\
0.557\end{array}$ & $\begin{array}{r}0.557- \\
0.592\end{array}$ & $\begin{array}{r}0.592- \\
0.626\end{array}$ & $\begin{array}{c}0.626-1 \\
0.661\end{array}$ & $\begin{array}{c}\text { Median } \\
\text { size }\end{array}$ \\
\hline \multirow[t]{28}{*}{$\hat{\sigma}$} & $\begin{array}{l}\text { 20. ii } \\
\text { 27. ii }\end{array}$ & $\begin{array}{r}8 \\
23\end{array}$ & $\because$ & $\because$ & $\because$ & . & . & 5 & 3 & $\cdots$ & .. & .. & \\
\hline & $\begin{array}{r}27 . \mathrm{in} \\
7 . \mathrm{iii}\end{array}$ & $\begin{array}{l}23 \\
26\end{array}$ & $\ddot{x}$ & 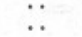 & $\because$ & 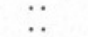 & $\because$ & $\begin{array}{r}12 \\
9\end{array}$ & II & $\ddot{2}$ & $\because$ & $\because$ & $\begin{array}{l}0.522 \\
0.528\end{array}$ \\
\hline & I3. iii & 9 & . & .. & .. & .. & .. & I & $\begin{array}{r}15 \\
8\end{array}$ & $\begin{array}{l}2 \\
.\end{array}$ & $\because$ & $\because$ & $\begin{array}{l}0.528 \\
0.539\end{array}$ \\
\hline & 20. iii & I5 & .. & . & . & . & .. & 4 & 9 & $\ddot{2}$ & $\therefore$ & $\because$ & $\begin{array}{l}0.539 \\
0.542\end{array}$ \\
\hline & 4. iv & 12 & . & $\cdots$ & $\cdots$ & . & $\cdots$ & . & 7 & 5 & .. & .. & 0.554 \\
\hline & Io. iv & 37 & . & . & . & . & . & I & I7 & I9 & .. & .. & 0.559 \\
\hline & $\begin{array}{l}17.1 \mathrm{~V} \\
24\end{array}$ & $\begin{array}{l}34 \\
46\end{array}$ & $\because$ & $\cdots$ & . & . & $\cdots$ & I & 20 & 13 & .. & .. & 0.552 \\
\hline & 24. iv & 46 & $\because$ & $\because$ & . & $\because$ & .. & $\because$ & $2 I$ & 25 & .. & .. & 0.559 \\
\hline & I. V & $\begin{array}{l}65 \\
57\end{array}$ & $\because$ & $\because$ & $\because$ & . & . & 2 & $4 \mathrm{I}$ & 22 & $\cdots$ & . & 0.550 \\
\hline & 8. v & 57 & $\cdots$ & $\cdots$ & $\cdots$ & . & $\cdots$ & 3 & 44 & 10 & .. & .. & 0.548 \\
\hline & $15 . \mathrm{V}$ & I9 & $\cdots$ & .. & . & . & .. & 4 & Io & 5 & .. & .. & 0.532 \\
\hline & 22. v & I4 & $\cdots$ & . & . & . & .. & I & I3 & .. & .. & .. & 0.538 \\
\hline & 29. v & 32 & . & . & .. & . & .. & 4 & 27 & I & . & .. & 0.537 \\
\hline & 5. vi & 49 & $\because$ & $\because$ & $\because$ & $\cdots$ & . & 3 & 37 & 9 & .. & $\cdots$ & 0.542 \\
\hline & I2. vi & $\begin{array}{l}94 \\
82\end{array}$ & $\because$ & $\cdots$ & $\because$ & . & . & 5 & 65 & 24 & . & .. & 0.548 \\
\hline & I9. vi & 82 & $\cdots$ & $\cdots$ & $\cdots$ & . & $\cdots$ & 3 & 67 & I2 & $\ldots$ & .. & 0.546 \\
\hline & 26. vi & 90 & $\cdots$ & $\cdots$ & $\cdots$ & . & $\cdots$ & I4 & 75 & I & .. & .. & 0.534 \\
\hline & 3. vii & 85 & . & . & $\cdots$ & . & .. & 36 & 49 & .. & .. & .. & 0.525 \\
\hline & Io. vii & $9 \mathrm{I}$ & . & . & .. & .. & .. & 21 & 70 & . & . & .. & $0.53 \mathrm{I}$ \\
\hline & 17. vii & II5 & $\cdots$ & . & . & . & . & 22 & 92 & I & .. & .. & 0.530 \\
\hline & 24. vii & 88 & $\because$ & $\cdots$ & . & $\cdots$ & . & 50 & 38 & . & $\ldots$ & . & 0.520 \\
\hline & 3r. vii & 95 & $\because$ & $\cdots$ & . & $\cdots$ & $\cdots$ & 72 & 23 & .. & $\ldots$ & .. & 0.516 \\
\hline & 7. viii & 46 & . & .. & . & .. & 5 & 40 & I & .. & $\ldots$ & .. & 0.499 \\
\hline & 14. vili & 40 & $\cdots$ & . & $\cdots$ & . & 6 & 33 & I & . & .. & .. & 0.496 \\
\hline & 21. vili & 68 & . & . & . & . & 6 & 61 & I & .. & . & $\cdots$ & 0.500 \\
\hline & 28. viii & 67 & . & .. & . & .. & 37 & 30 & .. & $\cdots$ & $\cdots$ & $\cdots$ & 0.486 \\
\hline & II. ix & 71 & .. & . & . & . & II & 60 & $\because$ & $\cdots$ & . & . & 0.498 \\
\hline & 2. $x$ & 72 & . & $\cdots$ & $\cdots$ & $\cdots$ & 6 & 65 & I & .. & .. & .. & 0.500 \\
\hline 우 & 17. $\mathrm{i}$ & 123 & .. & . & $\because$ & $\cdots$ & 3 & 49 & 67 & 4 & $\because$ & .. & 0.525 \\
\hline & $23 \cdot i$ & 194 & . & $\because$ & $\because$ & $\because$. & $\begin{array}{l}2 \\
4\end{array}$ & $\begin{array}{r}105 \\
66\end{array}$ & 83 & $\begin{array}{l}3 \\
I\end{array}$ & I & . & $0.52 \mathrm{I}$ \\
\hline & 30. 1 & $\begin{array}{r}126 \\
97\end{array}$ & $\because$ & $\because$ & $\because$ & $\because$. &.. & $\begin{array}{l}06 \\
35\end{array}$ & $\begin{array}{l}55 \\
60\end{array}$ & $\begin{array}{l}1 \\
2\end{array}$ & $\cdots$ & . & 0.518 \\
\hline & 6. ii & 97 & $\because$ & $\because$ & $\because$ & $\because$ & $\ddot{2}$ & 54 & & & . & .. & 0.528 \\
\hline & 13. ii & $\begin{array}{l}83 \\
67\end{array}$ & $\because$ & $\because$ & $\because$ & & & 34 & 23 & 4 & . & .. & 0.517 \\
\hline & 20. ii & $\begin{array}{l}67 \\
88\end{array}$ & 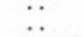 & $\because$. & $\because$ & $\cdots$ & I & 26 & 34 & 6 & .. & .. & \\
\hline & 27. i1 & & $\because$ & $\because$. & & . & . & 32 & 50 & 6 & .. & .. & 0.529 \\
\hline & 7. ifi & $\begin{array}{l}71 \\
73\end{array}$ & $\therefore$ & $\ldots$ & $\because$ & . & .. & 30 & 34 & 7 & .. & $\cdots$ & 0.526 \\
\hline & 13. iii & $\begin{array}{l}73 \\
69\end{array}$ & $\because$ & .. & & $\cdots$ & . & 23 & 40 & Io & $\cdots$ & . & 0.530 \\
\hline & 20. iii & $\begin{array}{l}69 \\
30\end{array}$ & $\because$ & . & & . & . & $2 \mathrm{I}$ & 37 & 8 & 3 & . & 0.534 \\
\hline & 27. iii & 39 & $\because$ & $\because$ & $\cdots$ & .. & . & I6 & I6 & 7 & .. & .. & 0.528 \\
\hline & 4. iv & 126 & . & $\cdots$ & $\cdots$ & .. & . & $3 I$ & 52 & 30 & 13 & .. & 0.539 \\
\hline & Io. iv & 69 & . & .. & .. & .. & I & 12 & 29 & 12 & 15 & .. & 0.546 \\
\hline & I7. iv & 105 & .. & .. & .. & .. & I & 7 & 35 & $2 I$ & 40 & I & 0.574 \\
\hline & 24 . iv & 82 & . & .. & . & .. & .. & 3 & 6 & 34 & 38 & I & 0.590 \\
\hline & I. v & 97 & .. & . & $\cdots$ & . & $\cdots$ & 2 & I0 & 36 & 45 & 4 & 0.593 \\
\hline & $8 . \mathrm{v}$ & 85 & . & . & $\cdots$ & .. & I & 3 & Is & 35 & 30 & I & $0.58 \mathrm{I}$ \\
\hline & I5. V & 69 & .. & .. & .. & .. & .. & 2 & 26 & 33 & 8 & .. & 0.563 \\
\hline & 22. v & 77 & . & $\cdots$ & .. & .. & $\cdots$ & 4 & 23 & 32 & I6 & 2 & 0.569 \\
\hline & $29 . \mathrm{v}$ & 85 & . & $\cdots$ & . & .. & . & 2 & 19 & 49 & 12 & 3 & 0.570 \\
\hline & 5. vi & 95 & . & $\cdots$ & .. & $\cdots$ & .. & 4 & 26 & 54 & I0 & I & 0.568 \\
\hline & I2. vi & IO3 & .. & .. & $\cdots$ & $\cdots$ & $\cdots$ & I & 28 & 62 & 12 & .. & 0.571 \\
\hline & I9. vi & 112 & $\cdots$ & $\cdots$ & $\cdots$ & $\cdots$ & $\cdots$ & I & 27 & 73 & Io & I & 0.571 \\
\hline & 26. vi & $9 \mathrm{I}$ & .. & . & . & . & $\cdots$ & 2 & 34 & 50 & 5 & .. & 0.563 \\
\hline & 3. vii & 98 & .. & . & . & .. & .. & I & 54 & 37 & 6 & $\ldots$ & 0.554 \\
\hline & Io. vii & $9 \mathrm{I}$ & .. & .. & .. & .. & .. & .. & $4 \mathrm{I}$ & 46 & 4 & . & 0.560 \\
\hline & 17. vii & 94 & . & .. & .. & .. & .. & 4 & $6 \mathrm{I}$ & 25 & 4 & .. & 0.547 \\
\hline & 24. vii & 74 & . & . & . & $\cdots$ & $\cdots$ & 17 & 48 & 9 & .. & $\ldots$ & 0.535 \\
\hline & 3I. vii & $9 \mathrm{I}$ & .. & .. & . & $\cdots$ & . & 27 & 58 & 6 & .. & .. & 0.530 \\
\hline & 7. vilii & 78 & $\cdots$ & . & .. & .. & .. & 52 & 25 & I & .. & . & 0.517 \\
\hline & I4. viii & 61 & . & $\cdots$ & . & . & $\cdots$ & 45 & I6 & .. & $\cdots$ & $\cdots$ & 0.515 \\
\hline & 21. vili & 95 & . & .. & .. & .. & 2 & 46 & 47 & $\cdots$ & $\cdots$ & . & 0.522 \\
\hline & 28. viii & 65 & $\cdots$ & $\cdots$ & . & $\cdots$ & 2 & $4 \mathrm{I}$ & 22 & . & $\cdots$ & $\cdots$ & \\
\hline & II. ix & 60 & . & $\cdots$ & $\cdots$ & $\cdots$ & . & 44 & 16 & $\cdots$ & $\cdots$ & .. & 0.516 \\
\hline & 2. $x$ & 65 & . & . & . & .. & .. & 39 & 25 & I & .. & .. & 0.519 \\
\hline V & I7. $\mathrm{i}$ & 53 & .. & .. & .. & 5 & 28 & I9 & I & .. & .. & .. & 0.480 \\
\hline & $23 . \mathrm{i}$ & 49 & . & $\cdots$ & .. & . & 30 & 18 & I & . & $\cdots$ & $\cdots$ & 0.482 \\
\hline & 30. i & 27 & . & $\because$ & .. & I & II & 13 & 2 & $\cdots$ & $\cdots$ & $\cdots$ & 0.494 \\
\hline & 6. ii & I2 & $\cdots$ & $\cdots$ & $\cdots$ & $\because$ & 4 & 6 & 2 & $\cdots$ & . & $\ldots$ & \\
\hline & 13. ii & 18 & $\cdots$ & $\cdots$ & $\cdots$ & I & 5 & 10 & 2 & $\cdots$ & .. & $\ldots$ & 0.506 \\
\hline & 20. ii & $\begin{array}{l}54 \\
88\end{array}$ & . & $\cdots$ & $\cdots$ & $\because$ & 8 & 23 & 23 & . & $\cdots$ & . & 0.512 \\
\hline & 27. ii & 88 & $\cdots$ & . & $\cdots$ & 3 & 22 & 42 & $2 \mathrm{I}$ & $\because$ & $\cdots$ & $\cdots$ & 0.501 \\
\hline & 7. iii & 95 & $\cdots$ & $\cdots$ & .. & I & 12 & 48 & 32 & 2 & . & . & 0.5 \\
\hline & I3. iii & 39 & .. & $\cdots$ & . & . & 8 & II & I9 & I & $\cdots$ & $\cdots$ & 0.524 \\
\hline & 20. iii & 93 & $\cdots$ & $\cdots$ & $\cdots$ & $\cdots$ & 9 & 43 & 37 & 4 & $\ldots$ & $\ldots$ & 0.519 \\
\hline & 27. iii & 13 & $\cdots$ & $\cdots$ & . & $\cdots$ & 3 & 3 & 6 & I & $\cdots$ & $\ldots$ & 0.539 \\
\hline & 4. iv & 26 & $\cdots$ & $\cdots$ & $\cdots$ & $\cdots$ & $\cdots$ & 3 & 16 & 7 & $\cdots$ & $\ldots$ & 0.546 \\
\hline & Io. iv & 36 & $\cdots$ & . & $\cdots$ & . & I & Io & I8 & 7 & $\cdots$ & $\cdots$ & 0.540 \\
\hline & I7. iv & 132 & . & . & .. & .. & I & I4 & 75 & 42 & $\cdots$ & $\cdots$ & 0.546 \\
\hline & 24 , iv & 66 & . & $\cdots$ & $\cdots$ & $\cdots$ & 4 & 34 & 27 & I & $\cdots$ & $\cdots$ & 0.536 \\
\hline & $\mathrm{r} \cdot \mathrm{v}$ & 107 & $\cdots$ & . & . & $\cdots$ & 6 & 44 & $5 \mathrm{I}$ & 6 & $\cdots$ & . & 0.524 \\
\hline & 8. v & $\begin{array}{l}87 \\
87\end{array}$ & $\cdots$ & $\cdots$ & . & $\because$ & 20 & 34 & 32 & & .. & $\cdots$ & 0.514 \\
\hline & $15 . \mathrm{v}$ & 81 & $\cdots$ & $\cdots$ & $\cdots$ & I & 22 & 39 & 19 & .. & $\cdots$ & $\cdots$ & 0.501 \\
\hline
\end{tabular}


TABLE XVI (cont.)

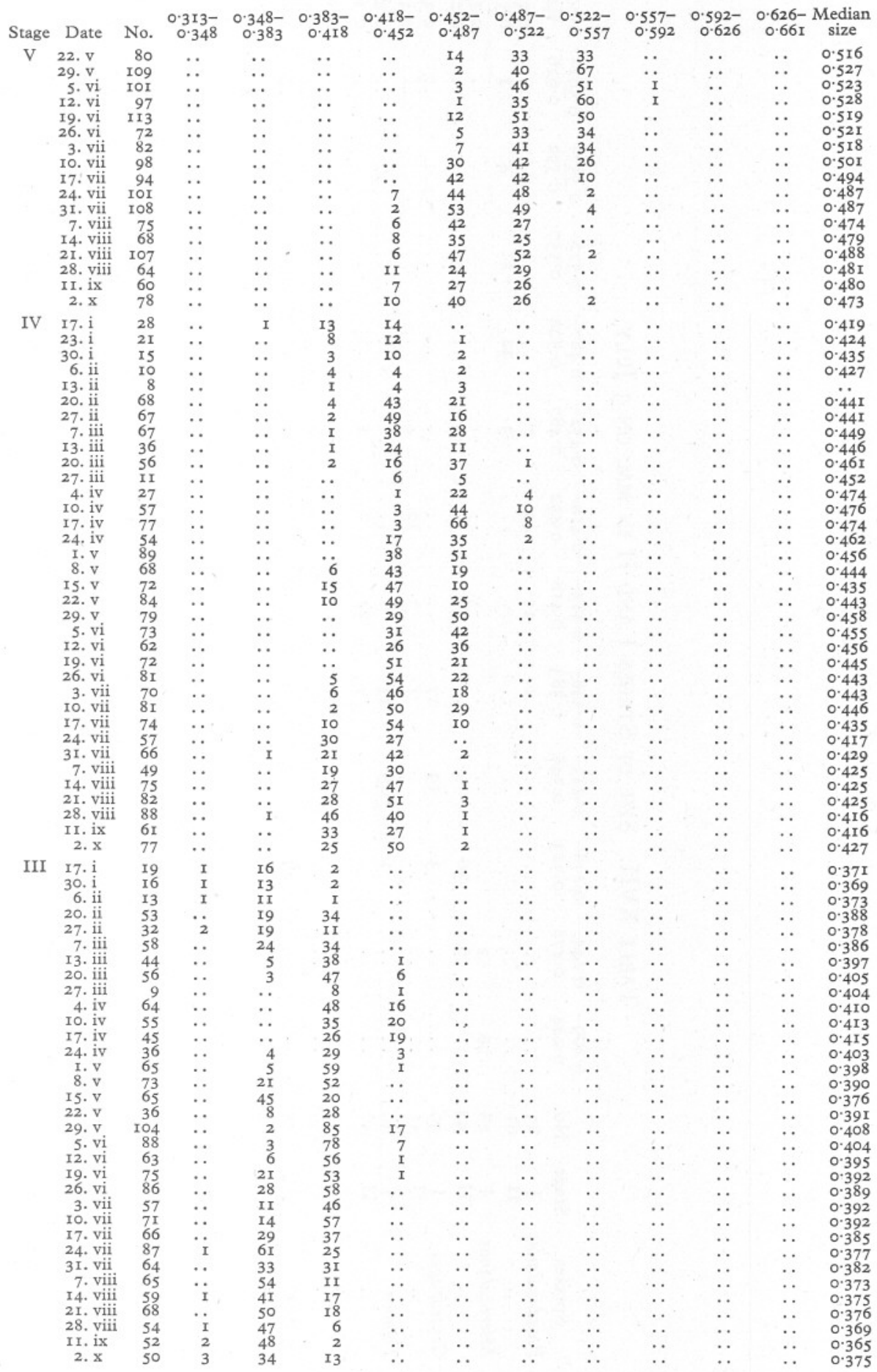


Table XVII. Size of Stages I and II IN Mm. on 3 July

\begin{tabular}{|c|c|c|c|c|c|c|c|c|c|c|c|c|c|c|c|}
\hline Species & Stage & No. & $\begin{array}{r}0.209- \\
0.244\end{array}$ & $\begin{array}{r}0.244- \\
0.278\end{array}$ & $\begin{array}{r}0.278- \\
0.313\end{array}$ & $\begin{array}{r}0.313- \\
0.348\end{array}$ & $\begin{array}{r}0.348- \\
0.383\end{array}$ & $\begin{array}{r}0.383- \\
0.418\end{array}$ & $\begin{array}{r}0.418- \\
0.452\end{array}$ & $\begin{array}{r}0.452- \\
0.487\end{array}$ & $\begin{array}{r}0.487- \\
0.522\end{array}$ & $\begin{array}{r}0.522- \\
0.557\end{array}$ & $\begin{array}{r}0.557- \\
0.592\end{array}$ & $\begin{array}{r}0.592- \\
0.626\end{array}$ & $\begin{array}{c}\text { Median } \\
\text { size }\end{array}$ \\
\hline Pseudocalanus & I & 83 & $\cdots$ & . & .. & .. & $\mathrm{I}$ & 35 & 40 & 7 & 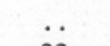 & $\because$ & $\because$ & $\cdots$ & 0.422 \\
\hline Micracalamus & II & $6 \mathrm{I}$ & $\because$ & & $\cdots$ & $\cdots$ & . & $\cdots$ & $\cdots$ & 3 & 32 & 21 & 4 & I & 0.519 \\
\hline $\begin{array}{c}\text { Microcalanus } \\
\text { ” }\end{array}$ & $\begin{array}{l}\text { I } \\
\text { II }\end{array}$ & $\begin{array}{l}28 \\
44\end{array}$ & $\begin{array}{l}26 \\
\cdots\end{array}$ & $\begin{array}{l}2 \\
6\end{array}$ & 36 & $\ddot{2}$ & $\because$ & $\because$ & $\because$. & $\because$. & 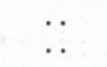 & . & $\begin{array}{l}. \\
\cdots\end{array}$ & $\because$. & $\begin{array}{l}0.226 \\
0.289\end{array}$ \\
\hline $\begin{array}{c}\text { Centropages } \\
\text {, }\end{array}$ & $\begin{array}{l}\text { I } \\
\text { II }\end{array}$ & $\begin{array}{l}39 \\
4 \mathrm{I}\end{array}$ & $\begin{array}{l}. \\
.\end{array}$ & $\ldots$ & $\begin{array}{c}3 \\
.\end{array}$ & $\begin{array}{l}19 \\
\ldots\end{array}$ & $\begin{array}{r}17 \\
\mathrm{I}\end{array}$ & $\ddot{7}$ & 29 & $\dddot{4}$ & $\begin{array}{l}. . \\
\ldots\end{array}$ & $\begin{array}{l}. \\
.\end{array}$ & $\begin{array}{l}. \\
.\end{array}$ & $\begin{array}{l}\ldots \\
\ldots\end{array}$ & $\begin{array}{l}0.346 \\
0.431\end{array}$ \\
\hline $\begin{array}{r}\text { Temora } \\
\text {, }\end{array}$ & $\begin{array}{l}\text { I } \\
\text { II }\end{array}$ & $\begin{array}{l}40 \\
36\end{array}$ & $\because$. & 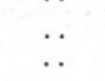 & $\begin{array}{l}\text { I } \\
. .\end{array}$ & $\begin{array}{l}25 \\
\cdots\end{array}$ & $\begin{array}{r}13 \\
9\end{array}$ & $\begin{array}{r}\text { I } \\
24\end{array}$ & $\ddot{2}$ & $\ddot{i}$ & $\ldots$ & $\begin{array}{l}\cdots \\
\cdots\end{array}$ & $\begin{array}{l}\cdots \\
\cdots\end{array}$ & $\begin{array}{l}\cdots \\
\cdots\end{array}$ & $\begin{array}{l}0.342 \\
0.398\end{array}$ \\
\hline $\begin{array}{r}\text { Acartia } \\
,\end{array}$ & I & $\begin{array}{l}47 \\
45\end{array}$ & $\begin{array}{l}. \\
\therefore\end{array}$ & $\begin{array}{l}. . \\
\ldots\end{array}$ & $\begin{array}{l}. \\
\therefore\end{array}$ & $\begin{array}{l}\ldots \\
\ldots\end{array}$ & $\begin{array}{l}24 \\
\ldots\end{array}$ & $\begin{array}{r}23 \\
3\end{array}$ & 24 & $\ddot{16}$ & $\ddot{2}$ & $\begin{array}{l}. \\
\ldots\end{array}$ & $\begin{array}{l}\ldots \\
\ldots\end{array}$ & $\begin{array}{l}\ldots \\
\ldots\end{array}$ & $\begin{array}{l}0.382 \\
0.483\end{array}$ \\
\hline $\begin{array}{r}\text { Oithona } \\
,\end{array}$ & $\begin{array}{l}\text { I } \\
\text { II }\end{array}$ & $\begin{array}{l}49 \\
32\end{array}$ & $\ldots$ & $\begin{array}{c}3 \\
. .\end{array}$ & $\begin{array}{l}46 \\
\ldots\end{array}$ & iI & $\ddot{2 I}$ & 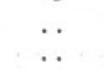 & 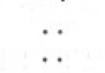 & $\ldots$ & . & $\begin{array}{l}. . \\
\ldots\end{array}$ & . & . & $\begin{array}{l}0.289 \\
0.353\end{array}$ \\
\hline
\end{tabular}

